Universidade de São Paulo

Escola de Comunicações e Artes

Departamento de Artes Cênicas

\title{
Jogos do Olhar - \\ procedimentos cinematográficos para a composição da cena teatral
}

VERÔNICA GONÇALVES VELOSO

São Paulo

2008 
VERÔNICA GONÇALVES VELOSO

\author{
Jogos do Olhar - \\ procedimentos cinematográficos \\ para a composição da cena teatral
}

Dissertação apresentada à Escola de Comunicações e Artes da Universidade de São Paulo, para a obtenção do título de Mestre em de Artes Cênicas.

Área de Concentração: Pedagogia do Teatro

Orientadora: Profa . Dra . Maria Lúcia de Souza Barros Pupo 


\section{FOLHA DE APROVAÇÃO}

Verônica Gonçalves Veloso

Jogos do Olhar - procedimentos cinematográficos para a composição da cena teatral

Dissertação apresentada à Escola de Comunicações e Artes da Universidade de São Paulo, para a obtenção do título de Mestre em de Artes Cênicas.

Área de Concentração: Pedagogia do Teatro

Aprovado em:

\section{BANCA EXAMINADORA}

Profa $^{a}$. Dra . Maria Lúcia de Souza Barros Pupo

Instituição: ECA/USP

Assinatura:

Prof. Dr.

Instituição:

Assinatura:

Prof. Dr.

Instituição:

Assinatura: 
Dedico esse trabalho

À minha mãe, que me ensinou a escrever Ao meu pai, que me ensinou a gostar de cinema Ao Rodrigo, o companheiro de todas as horas 


\section{Agradecimentos}

À professora orientadora Maria Lúcia Pupo, pelo estímulo, o exemplo e o rigor. Ao Coletivo - Jogos do Olhar, pelo envolvimento e incentivo, especialmente aos jogadores Anna Dulce, Kátia Lazarini, Paula Bellaguarda, Clóvis Lima, Daniel Cordova, Dri Escher, Felipe Pitta, Larissa Alvanhan, Júlio Barga e Juliana Bueno. Agradeço também a Juliana Matos, Jhony, Maria Carolina, Kátia Kuk, João Marcelo, Adriane Rodrigues, Priscila Quintiliano, Marina Tranjan, Pedro Melão, Arnaldo Wainstein e todos aqueles, que mesmo por um período breve, jogaram nesse Coletivo.

À Renata Velguim, pela presença incondicional, pelo empréstimo de seus olhos ao fotografar cada espaço e cena, pelos cartazes e pela diagramação final.

À Taty Kanter, pela iluminação e consultoria técnica, pela parceria e amizade, pela edição das cenas do DVD anexado na dissertação.

À Damyler Ferreira, pela ajuda durante a temporada, pela captação do som durante as filmagens e pela colaboração na edição do DVD.

A Jorge Wakabara, pela colaboração como figurinista e observador do processo.

À Paulina Caon, amiga e parceira de criações, pelo modelo, pelo ombro, pelo braço e pelos olhos tão atentos às cenas produzidas na Hidráulica.

A Pedro Plaza, pela orientação amiga, indicação de referências bibliográficas, conversas animadoras e apoio de sempre.

A Eduardo Azevedo, pela captação da encenação em audiovisual e elaboração de uma versão da encenação para vídeo. À Larissa Kurata, Jaqueline Plaça e Bruna Carvalho, equipe responsável pela edição e montagem da versão em vídeo (em processo de finalização).

À Marina Takami, pelos cartazes.

À Paula Carrara, pela parceria na preparação vocal dos jogadores.

À Lu Carion e Marcos Bulhões, meus mestres, a quem atribuo minha filiação artística.

À professora Sílvia Fernandes, pelos retornos e incentivos.

Ao professor Fábio Cintra, pela parceria como colaborador desse Coletivo.

Ao professor Lúcio Agra, pela rica colaboração no Exame de Qualificação.

Ao professor Ismail Xavier, pelas conversas e apoio e por possibilitar a realização das Sessões de Cinema dos Jogos do Olhar. 
Aos professores que debateram nas Sessões de Cinema promovidas pelo Coletivo - Jogos do Olhar: Luiz Fernando Ramos, Rubens Machado, Sérgio de Carvalho, Rubens Rewald e Francisco Alambert.

Aos amigos debatedores das Sessões de Cinema: Reinaldo Cardenuto, Paula Klein, Adilson Inácio Mendes, Pedro Plaza, Pedro Granato e Fábio Uchoa.

A Joel Yamaji, pela colaboração na organização das Sessões de Cinema.

Ao senhor Felisberto, pela disponibilidade como projecionista do Auditório Paulo Emílio.

A Nelson Hideyuki, o "Hide", guardião do Centro Tecnológico de Hidráulica $(\mathrm{CTH})$, pelo apoio, pela dedicação, por agir como facilitador dos encontros entre arte e ciência.

À Margareth, Celso, Rosana e todos os funcionários do CTH e Rádio USP.

A todos os que nos ajudaram durante da temporada de "ISAURA S/A": Raquel Veloso, Juliana Moura, Otávio, Jhow Carvalho, Danilo Lima e Rodrigo.

Aos primeiros espectadores de "ISAURA S/A": professor Luiz Fernando Ramos e Samir Signeu.

A todos os funcionários do Teatro Laboratório.

À minha família que mesmo distante esteve presente em cada passo do percurso, apoiando minhas escolhas, especialmente meus irmãos Fernanda e Luiz Fernando.

À minha mãe, Lúcia, pela dedicação e cuidado nas correções do texto.

Aos meus amigos, por tornarem a vida mais doce.

À minha recém adotada família paulistana, em especial à Helena Albuquerque.

À Lilian Tenório, pelo suporte e respeito silencioso ao meu trabalho e estudo.

Ao apoio da Cinemateca Brasileira.

Ao fomento da Fundação de Apoio à Pesquisa no Estado de São Paulo (FAPESP), sem o qual essa pesquisa não seria possível. 
"Eu teria treze anos.

De tarde fui olhar a Cordilheira dos Andes que se perdia nos longes da Bolívia.

$E$ veio uma iluminura em mim.

Foi a primeira iluminura.

Daí botei meu primeiro verso:

Aquele morro bem que entorta a bunda da paisagem.

Mostrei a obra pra minha mãe.

A mãe falou:

Agora você vai ter que assumir as suas

irresponsabilidades.

Eu assumi: entrei no mundo das imagens."

Manoel de Barros 


\section{Resumo}

VELOSO, Verônica Gonçalves. Jogos do Olhar - procedimentos cinematográficos para a composição da cena teatral. 2008. 224 f. Dissertação (mestrado) - Escola de Comunicações e Artes, Universidade de São Paulo, São Paulo, 2008.

Jogos do Olhar é uma pesquisa que coleciona procedimentos do cinema como recursos para resolver certos impasses da cena teatral contemporânea, tais como: a cena fora do espaço tradicional, o corpo como figura e não como personagem e o texto como materialidade. No teatro referido há a preponderância da imagem sobre o texto. Os procedimentos cinematográficos foram observados em alguns exemplares do Cinema Brasileiro Moderno. Essa investigação resultou em uma Coleção de Jogos organizada com o intuito de prover professores, encenadores e interessados em geral de recursos para a composição de cenas condizentes com as inquietações presentes no teatro contemporâneo. Todos os jogos selecionados serviram de mote para as cenas de "ISAURA S/A + 1 Experimento Hidráulico", investigação prática na qual se buscou entrelaçar processos de criação e educação. Essa encenação foi elaborada com a colaboração do Coletivo - Jogos do Olhar, agrupamento de artistas dedicados ao estudo das relações existentes entre o teatro e o cinema. A apropriação da linguagem cinematográfica pode contribuir para as operações presentes na teatralidade pós-cinema.

Palavras-chave: teatro, cinema, educação, encenação. 


\begin{abstract}
VELOSO, Verônica Gonçalves. Looking Games - cinematographic procedures for the composition of the theatrical scene. Essay (master) - Communication and Arts School -University of São Paulo, São Paulo, 2008.

Looking Games is a research that gathers movie procedures as resources to resolve certain impasses in the theatrical contemporary scene, such as: a scene outside the traditional space, the body as figure and not as character and the text as materiality. In such theater, there is predominance of image over text. Cinematographic procedures were observed in some examples of the Modern Brazilian Cinema. This investigation resulted in a Collection of Games organized with the goal of providing teachers, directors and interested parties in general, with resources for the composition of scenes congruous with the concerns present in contemporary theater. All games selected served as slogan for the scenes in "ISAURA S/A + 1 Hydraulic Experiment", a research practice which sought intercross creative and educational processes. This stage management was drawn up in collaboration with Collective - Looking Games, a group of artists dedicated to the study of existing relationships between the theater and the cinema. The appropriation of film language can contribute to the operations present in theatricality post-cinema.
\end{abstract}

Key-words: theater, cinema, education, staging. 


\section{SUMÁRIO}

Guia para o olhar

Capítulo 1: Ler a cena cinematográfica - um treino do olhar

1. Cena cinematográfica: paradigmas possíveis

2. Observação de filmes brasileiros: um recorte temporal

3. Análise do filme: aproximação dos procedimentos cinematográficos

4. Análise como treino do olhar - o estímulo para a formação do

Coletivo

Anexos 1

Capítulo 2: Recorte Fotográfico - Composição de Imagens

\section{Estáticas}

1. Arquitetura como espaço cênico

2. Escolha da locação

3. Conceito de representação inspirado na geometria

4. Procedimentos cinematográficos para novas arquiteturas teatrais

5. O Corpo como território do jogo

6. Na Sala Branca - do treinamento ao aquecimento: diálogos com Klauss Vianna e seus "atualizadores"

7. Imagem do corpo só \& imagem do corpo coletivo

Anexos II

Capítulo 3: Escrever a cena teatral com imagens

1. Uma dramaturgia para um teatro de imagens

2. O olhar de Klauss Vianna para Anne Bogart: do treinamento ao aquecimento

3. Filmes como modelo de ação e estoque de imagens

4. Roteiro: sucessão de planos e travellings para o público

6. O papel do tempo na formatação de um coletivo 
1. Textos: ditos, ouvidos e vistos

2. Trilha Sonora: vozes, ruídos, música gravada e desconstruída 174

3. Arquitetura como locus significativo: iluminação, fotografia e 191 figurino

4. Encenação e Coletivo - Jogos do Olhar: uma composição 200 paralela

Anexos IV

Operações do olhar 


\section{Guia para o olhar}

"Olhar é a luz que sai do olho" Zé Celso Martinez Correa, no filme

"Árido Movie", de Lírio Ferreira

O olhar é um sentido enaltecido por músicos e poetas. Alguns olhares podem ser facilmente relembrados: os olhos de azeviche cantados pela voz forte de Clementina de Jesus, os olhos de ciúme de Bentinho endereçados a Capitu no romance de Machado de Assis, além de alguns olhares marcantes de nosso cotidiano, de soslaio, de cumplicidade, de espanto, de compreensão. Um clichê ao referir-se ao olhar é compará-lo à janela da alma, no entanto, o olhar pode ser associado tanto à recepção quanto à expressão. É receptivo pela visão, pois é através dela que o mundo se desvela em forma de imagem. E também é expressivo, pois, de acordo com os poetas e músicos citados acima, o olhar diz, traduz sentimentos e emoções muitas vezes inomináveis. Confirmando essa afirmação, Roland Barthes escreve: "No verbo olhar, as fronteiras do ativo e do passivo não são nítidas" (BARTHES, 1990, p. 278). Portanto, ser ativo ou passivo em se tratando de olhar é relativo, pois enquanto olhamos também somos olhados.

"Jogos do Olhar" é uma pesquisa que busca em alguns procedimentos cinematográficos ferramentas para resolver certos impasses da cena teatral contemporânea. É um estudo sobre a escritura do visível, em um tempo em que o cinema tornou-se o paradigma dessa prática, seja por capturar 0 imaginário do teatro, seja pelos desdobramentos dessa linguagem nas novas tecnologias da imagem. Portanto, antes de escrever a cena no teatro, os Jogos do Olhar propõem a leitura da cena (visível e audível) do cinema. Olhando essa outra linguagem, compreendemos, pelo princípio da alteridade, as opções expressas nas teatralidades contemporâneas pós-cinema. Teatralidades no plural para evidenciar as múltiplas formas percebidas nas encenações de Bob Wilson, Antônio Araújo, Tadeusz Kantor, José Celso Martinez Corrêa, Christoph Schlingensief, Enrique Diaz, Pina Bausch, Gerald Thomaz, Wladyslaw Snorko, Robert Lepage, entre outros. 
Falamos em jogo para melhor caracterizar a cena teatral à qual nos referimos: fora do edifício tradicional, utilizando qualquer espaço arquitetônico como locação, onde o corpo está presente como figura e não como personagem e onde o texto não tem lugar de destaque dentro da encenação. Trata-se de uma cena em que há a preponderância da imagem sobre o texto, pois ao promover a des-hierarquização dos elementos da cena, a balança pende para o lado da imagem. Esse teatro aprendeu com a arte moderna "a desmanchar o paralelismo entre sentido e representação" (FILHO, O. F., 1994, apud COHEN, 1998, p. 7) $)^{1}$ e a "confessar o gesto de mostrar" (GUÉNOUN, 2004, p. 142). O que esses olhos olham é a "sobriedade lúdica e operatória" do jogo, não o seu "efeito de ilusão" (Ibidem). Nesse teatro sem história, sem personagem, sem conflito, o que se percebe é a operação da teatralidade, entendida aqui como o jogo cênico.

\begin{abstract}
Ver um espetáculo é ver a teatralidade em sua operação própria: a operacionalização, o verter (a versão) no teatro, o gesto de levar para a cena uma realidade não cênica, poema ou narrativa. Ir ver um espetáculo é exatamente ir ao encontro de uma encenação, de uma colocação no palco, de uma operação de exibição enquanto exibição, autônoma e singular em relação às entidades imaginárias cuja existência, até então reservada, ela materializa. Operação que é um modo do que aqui se tenta definir como jogo. (GUÉNOUN, 2004, p. 140 , grifo do autor)
\end{abstract}

A palavra jogo remete, então, a uma operação prática, de materialização do visível. Afinada com a brincadeira, o esporte e o faz-de-conta, o jogo envolve respeito, envolvimento e prazer. São muitas as modalidades de jogo e de certa forma, todas se referem à experiência coletiva e lúdica. "Nós podemos dizer a respeito de qualquer jogo que ele é [...] uma maneira alada de viver a vida" (FINK, E. 1966, p.79 apud GUÉNOUN, 2004, p. 142)². Esta investigação aborda o jogo da cena contemporânea como instrumento para formação do homem, por meio da observação e seleção de elementos que caracterizam formalmente a cena.

\footnotetext{
${ }^{1}$ FILHO, Otávio Frias. Thomas Encontra a Esfinge da Narrativa. In: Folha de São Paulo, Caderno Mais!, 27 de fevereiro de 1994.

${ }^{2}$ FINK, E. Le jeu comme symbole du monde. Paris : Minuit, 1966.

2
} 
O olhar foi escolhido, nesse estudo, para nomear os jogos de aplicação de certos procedimentos cinematográficos nessa escritura cênica teatral, ou seja, será o responsável pela transcodificação de operações do cinema para o teatro. Essa proposta foi sistematizada em forma de uma Coleção de Jogos selecionados de algumas fontes (às vezes, criados) e destinados a professores/encenadores que se posicionam fora da cena, ou seja, no lugar de quem olha. Atores e interessados por teatro e cinema em geral, ou aqueles que se interessam pela interação entre linguagens, também encontrarão nesse estudo pistas para levar adiante suas investigações. Os Jogos do Olhar abarcam modalidades de jogo que se destinam a operar o espaço, o corpo, o tempo e o texto na cena, colecionados com o intuito de contemplar as novas exigências da cena contemporânea. Aproximando o jogo teatral do cinematográfico, não pretendo propor receitas, nem definir um estatuto das influências do cinema no teatro.

A pesquisa aqui apresentada foi acompanhada de uma encenação teatral intitulada "ISAURA S/A + 1 Experimento Hidráulico", na qual investigamos a aplicabilidade desses jogos como mote para a criação das cenas. Para tanto, um Coletivo formado por uma média de quinze pessoas foi constituído ao longo de um ano e meio de investigações práticas. Os participantes, em sua maioria estudantes de Artes Cênicas da USP, foram convidados a integrar o Coletivo por meio de um cartaz espalhado na Cidade Universitária, convocando quaisquer interessados maiores de 17 anos.

Como consideramos todo processo criativo um processo de ensinoaprendizagem, a proposta era desenvolver um processo artístico e pedagógico de forma integrada, sem dissociações entre o momento da aprendizagem e o momento da criação. Por isso, utilizamos os termos ator e jogador na mesma acepção, indiferentemente. Da mesma forma, buscamos uma simbiose das funções do professor e do encenador. O processo de criação da encenação aconteceu de forma colaborativa, por isso ao longo da dissertação optei por utilizar a primeira pessoa do plural, com exceção dos momentos em que me posicionava particularmente, como por exemplo, na relação da professoraencenadora com o Coletivo, quando usei a primeira pessoa do singular.

Minha formação teatral se deve a experiências muito frutíferas vivenciadas em dois grupos: a Tribo de Teatro Tumutupugá e o OBARA - 
Grupo de Pesquisa e Formação em Teatro-Dança. Os dois grupos se estruturaram em experimentações práticas vinculadas a pesquisas de mestrado na ECA/USP. No primeiro, a Tumutupugá, aprendi a olhar para o espaço arquitetônico estudado na antiga faculdade (cursei Arquitetura durante um ano e meio) como espaço cênico em potencial, graças aos ensinamentos de Marcos Bulhões. No segundo, OBARA, aprendi a olhar para o corpo como território do jogo, graças aos ensinamentos de Lu Carion. A partir dessas duas experiências, que me resultaram noções de espaço e corpo, pude desenvolver a presente pesquisa e cultivar princípios de não dissociação entre teoria e prática, ensino e aprendizagem, educação e criação. Essas experiências me ensinaram a importância de se eleger os mestres como forma de construir quem somos, pois outros mestres os precedem e, às vezes, são eles ou mais velhos, as vozes que falam através de nós.

Por isso, muito do que se apresenta nessa dissertação é fruto de experiências práticas anteriores a essa. A exploração de espaços diversos para serem transformados em espaços cênicos, a composição de roteiros dramatúrgicos a partir da compilação de textos "apropriados" e a criação pelo work in progress estavam presentes na encenação 1999, coordenada por Marcos Bulhões, comentada no livro "Encenação em Jogo" (MARTINS, 2004). $\mathrm{O}$ estudo do corpo no que se refere ao autoconhecimento e à apreensão de princípios que possibilitam que meu olhar se volte para outros corpos (como professora e encenadora) se deve ao aprendizado da Técnica Klauss Vianna, de acordo com os desdobramentos desenvolvidos por Lu Carion (BRAZ, 2004). Por fim, a idéia de se compor o teatro a partir da observação do cinema tem suas raízes fincadas na primeira encenação do OBARA, intitulada "Donos do Corpo", criada a partir de roteiros de filmes de Glauber Rocha.

A dissertação que segue está estruturada em quatro capítulos que comportam também a Coleção de Jogos do Olhar. Os jogos estão compilados ao final de alguns itens (dentro dos capítulos) e destacados por enquadramentos que os isolam dos demais. No primeiro capítulo, fazemos uma apresentação de procedimentos cinematográficos retirados de um período específico da História do Cinema. No segundo capítulo, discutimos a composição da cena teatral como se fosse um fotograma, uma fotografia, ou seja, uma imagem estática. Por isso os jogos que o acompanham se referem 
ao espaço e ao corpo, destacando-se jogos referentes aos princípios técnicos de Klauss Vianna.

No terceiro capítulo, dotamos as imagens de movimento e recorremos aos filmes como modelo de ação ou estoque de imagens. Nesse capítulo estão presentes as modalidades de jogo que se referem ao corpo em movimento, destacando-se versões dos jogos propostos por Anne Bogart a partir de seu The Viewpoints Book. Há ainda jogos referentes à operação do elemento Tempo dentro da cena. Nos capítulos um, dois e três, incluímos também análises de filmes e encenações, sempre separados por um traço que as distingüem do todo, como forma de aproximação do cinema estudado e do teatro pretendido. No quarto e último capítulo, apresentamos um modo cinematográfico de compor a cena teatral a partir da sobreposição de textos, músicas e ruídos às imagens criadas. Tratamos ainda de elementos complementares, mas não menos importantes para a composição da cena: a iluminação, a fotografia e o figurino.

Ao final de cada capítulo dedicamos um item para discutir dois fios da pesquisa descritos paralelamente: a composição da encenação e a configuração do Coletivo - Jogos do Olhar. Notamos, no decorrer da investigação, que cada módulo de trabalho prático influenciava intimamente a formatação da coletividade.

Cada capítulo é encerrado com um bloco de anexos que compreende cartazes produzidos para os eventos realizados paralelamente à pesquisa, além de fotografias e textos. No anexo IV inserimos o roteiro final da encenação, entremeado de fotografias das cenas, contribuição que poderá dar algum norte para o leitor que não assistiu à "ISAURA S/A". Com o mesmo objetivo, anexamos um DVD com algumas cenas da peça editadas, a partir de material coletado em ensaios e apresentações. Nesse mesmo anexo, inserimos também um mapa que localiza a Hidráulica dentro da Cidade Universitária, desenhado por uma de nossas colaboradoras na ocasião da temporada da encenação.

O texto que se segue é resultado de uma ampla investigação, possível apenas pelo interesse e boa vontade dos jogadores e demais colaboradores que integraram o Coletivo - Jogos do Olhar. Todas essas pessoas são vozes presentes nesse discurso; não saberia discerni-las de minha própria voz em 
muitos momentos. Mesmo nos momentos dedicados à escrita, atividade de caráter solitário, reconhecia um Coletivo que sussurrava de maneira polifônica e muitas vezes, discordante, ao meu ouvido. Dedico esse trabalho a todas as pessoas que de algum modo me ajudaram nessa passagem, propondo movimentos de continuidade ou de interrupção, mas que mantiveram vivo o desejo de investigação. Espero que os leitores, através dessas palavras, experimentem o gosto desse processo de criação e aprendizagem e, ao mesmo tempo, explorem, eles mesmos, seus jogos do olhar. 


\section{Capítulo 1: Ler a cena cinematográfica - um treino do olhar}

\section{Cena cinematográfica: paradigmas possíveis}

Na virada do século XIX para o XX, um conjunto de cidadãos correu ao assistir a projeção da imagem de uma locomotiva que vinha em sua direção. As impressões das pessoas dessa época foram intensificadas, talvez elevadas à décima potência nos dias atuais, no que diz respeito à percepção da vida metropolitana. Entre os cidadãos que correram da projeção e nossos contemporâneos, mudanças significativas aconteceram. Passados mais de cem anos, a cidade é cada vez mais produtora e consumidora de imagens: há televisores, vídeos, computadores, celulares, câmeras de vigilância, letreiros luminosos, outdoors colocados em seqüência em pistas de alta velocidade. $O$ aparecimento do cinema pareceu fornecer um treinamento para lidar com os estímulos do mundo moderno, de acordo com afirmativa de Walter Benjamin. Paralelamente, acredita-se que a cultura moderna tenha sido "cinematográfica" antes mesmo do advento do cinema. Tal advento, no entanto, pode ser considerado uma resposta à sensação da vida na metrópole.

\footnotetext{
O cinema corresponde a mudanças profundas no aparelho aperceptivo - mudanças que são experimentadas, em uma escala individual, pelo homem na rua, no tráfego da cidade grande e, em escala histórica, por qualquer cidadão dos dias de hoje. (BENJAMIN, 1985, apud CHARNEY; SCHWARTZ, 2004, p.115).
}

De uma forma ou de outra, fomos muito bem treinados para suportar o bombardeio de estímulos ao qual fomos submetidos no último século: seqüência rápida de imagens, descontinuidade temporal, formas velozes de transporte, horários associados ao capitalismo e à velocidade acelerada das linhas de montagem. Por sintetizar em sua experiência a condição da vida moderna, marcando o imaginário de todo o século $X X$, pode-se dizer que 0 cinema é o paradigma, a expressão que se desenvolveu como resposta desse imaginário hiperestimulado. Se o cinema e a modernidade são pontos de convergência, esse é o motivo pelo qual escolhemos o cinema como a linguagem mais apropriada para atender às expectativas da cena teatral contemporânea. Nesse estudo, o cinema foi escolhido por constituir-se o 
paradigma inclusive de linguagens tão presentes no nosso cotidiano como o vídeo e a televisão. Além disso, inspirou de forma mais abrangente, a música, as artes plásticas e a literatura, entendida por muito tempo como o modelo para a composição teatral.

Denis Guénoun, no livro "O teatro é necessário?”, afirma que o termo "imaginário", como substantivo, é contemporâneo do aparecimento do cinema. Segundo ele, "o cinema é o tornar-se-imagens do imaginário" (GUÉNOUN, 2004 , p. 109, grifo do autor), fato que o autor também associa ao surgimento da função do encenador na arte do teatro.

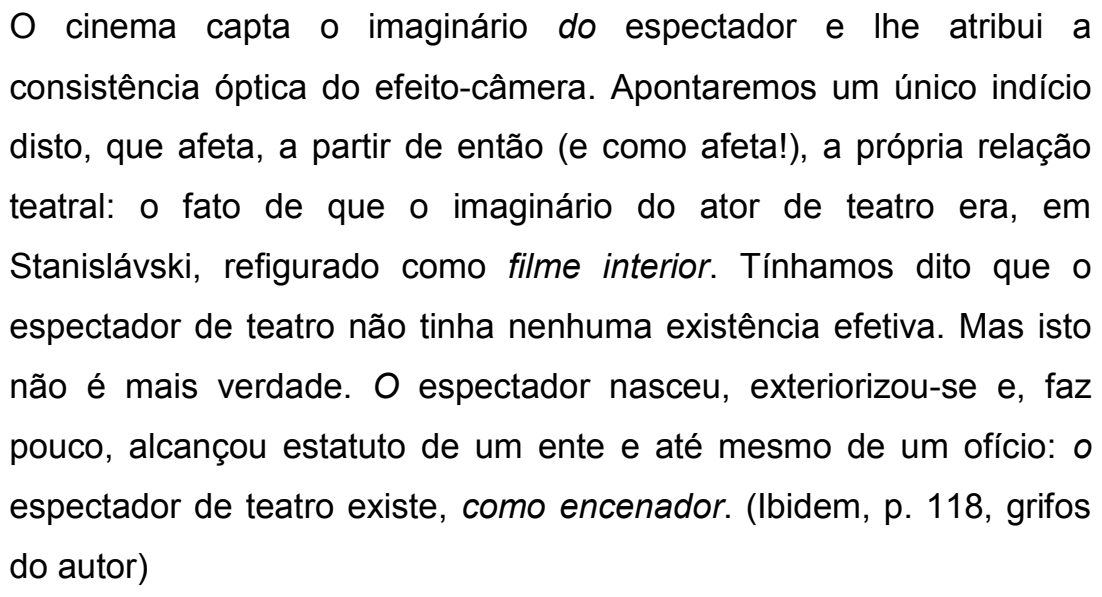

A situação atual do teatro não encontra mais na literatura a expressão de seus questionamentos e conflitos; vivemos a era da imagem, da fragmentação e da simultaneidade de muitos estímulos. Atualmente no teatro, o texto não é considerado o protagonista, o espaço nem sempre é a sala à italiana e as fronteiras entre a representação e a realidade estão cada vez mais borradas, por isso o intercâmbio com outras linguagens pode apresentar pistas para entender as novas formas de escritas teatrais. Pode-se dizer, grosso modo, que o que há em comum entre teatro, cinema e vídeo é o fato de se tratarem de meios de reprodução de cenas visíveis. Antes do cinema, o teatro era o único meio de se produzir cenas visíveis em movimento (as cenas visíveis nas pinturas podiam no máximo produzir ilusão de movimento). A literatura, por sua vez, descrevia cenas imagináveis, não visíveis. Talvez a internet seja a meio de comunicação, e não mais a TV, que melhor represente nosso tempo, por conjugar em sua estrutura o áudio, o visual e o textual, além de disponibilizar rapidamente seus produtos para circulação e acesso em qualquer lugar do 
mundo, o que não acontece com a literatura, o teatro e o cinema. Pode-se dizer que o vídeo seja a linguagem com a qual a internet melhor dialoga, por sua capacidade de articular esses elementos e pelo desenvolvimento tecnológico que facilita tanto sua produção quanto seu consumo. Considero relevante, por isso, afirmar que essa pesquisa poderia apoiar-se em outro suporte, diferente do cinematográfico, para elaborar o teatro contemporâneo. O cinema foi apenas o pioneiro a compartilhar com o teatro a capacidade de produzir imagens visíveis, ampliando, por suas características técnicas, as possibilidades de escritura desse visível.

Então, buscamos o cinema na esperança de que alguns procedimentos específicos dessa linguagem respondessem aos impasses da cena teatral contemporânea. Entretanto, grande parte da produção cinematográfica segue os princípios do cinema narrativo clássico, utilizando seus procedimentos de modo a criar "impressão de realidade", buscando provocar a ilusão de que assistimos a um evento real. Seguindo as convenções narrativas preconizadas por Griffith, esses filmes aproximam-se de uma estética realista, o que nos levaria a tomar o cinema como paradigma para a elaboração de um teatro também realista. Geralmente, o enredo privilegia as relações de causa e efeito, revelando a primazia da continuidade, possível graças ao desenvolvimento das técnicas de decupagem que escondem o corte e ressaltam a continuidade da ação. Embora reconheça a possibilidade do cinema inspirar a criação teatral em uma formatação dramática, tomamos a escritura cinematográfica como modelo para a composição de um teatro pós-dramático.

Se tomarmos o eixo continuidade/descontinuidade como referência, tal qual nos propõe Ismail Xavier em "O olhar e a cena", verificamos a ausência do narrador no cinema narrativo clássico, cuja intervenção colaboraria para a interrupção da ação. A oposição entre mostrar e relatar dotou o teatro e, de certo modo, também o cinema a partir da década de 60 , de um caráter épico, uma vez que alguns cineastas exploraram essa descontinuidade seguindo o modelo instaurado por Bertolt Brecht. Comparando as escrituras cinematográficas e teatrais, poderíamos afirmar que o teatro épico seria aquele que se encontra mais próximo das características identificáveis no cinema moderno, sobretudo nos movimentos intitulados "cinemas novos". Isso não quer dizer que a cinematografia atual não continue reinventando o diálogo com 
os gêneros, assumindo por vezes características épicas: no modo de se relacionar com a câmera, no uso da voz do narrador, nas interrupções e descontinuidades da narrativa.

Embora os filmes provenientes do cinema moderno aproximem-se mais do teatro épico, nosso interesse volta-se para a elaboração de um teatro pósBrecht. Nesse sentido, notamos nesse recorte cinematográfico a exposição dos meios de criação, exibindo seus procedimentos e revelando os dois momentos da composição do filme: a filmagem e a montagem. A movimentação da câmera é sensível, o corte é nítido e é recorrente a dissociação entre imagem e sonoridade, tamanha a utilização do recurso da voz over. Esses são alguns motivos que nos levaram a debruçarmos sobre um recorte histórico do cinema brasileiro: sete filmes realizados entre 1965 e 1972, época de grande efervescência do cinema nacional. Voltaremos mais adiante ao detalhamento das características dos filmes desse período $e$ as possibilidades de determinados procedimentos presentes neles solucionarem certos impasses vividos pela cena teatral atual. O que nos parece relevante destacar por hora, na materialidade do dispositivo cinematográfico posterior à introdução do som no cinema, é a presença de duas faixas: uma de imagem e uma de som. Em francês, usa-se a palavra bande (em português, "faixa") para designar uma sucessão de imagens ou sons organizados em seqüência.

Tal fator pode ser considerado didático para a análise a que nos propomos, uma vez que no cinema a concretude da imagem e do som é exacerbada pela existência dessas duas faixas. No teatro, a simultaneidade das informações transmitidas e o corpo-a-corpo dos atores com o público dificultam a percepção de que se trata de "um conjunto de signos lingüísticos (mensagem) que comanda um conjunto semiótico complexo" (UBERSFELD, 2005 , p. 157). Ou seja, os signos presentes na linguagem teatral são constituídos de matérias diferentes: arquitetura cênica, corpos, voz, música, luz, textos ouvidos e lidos. À semelhança do cinema, a significação teatral envolve muitos suportes, cujas existências são camufladas pela produção integrada da imagem e do som. Encenadores como Bob Wilson (para citar um exemplo entre outros) chegaram a essa constatação e deram relevância a esses diferentes suportes, separando a emissão das faixas de imagem e de som. Bob Wilson inclusive é esclarecedor ao afirmar que "seu ideal de teatro é 10 
uma junção de cinema mudo e peça radiofônica" (LEHMANN, 2007, p. 255). Hans-Thies Lehmann acrescenta que o teatro "é um cinema tridimensional" (Idem, 2003, p.12), caso quisesse uma caracterização para o teatro.

Ao constatar a valorização da presença de suportes sincréticos no teatro por encenadores contemporâneos, concluímos que o fato de as faixas de imagem e som serem "descoladas" pode ser um dado facilitador da percepção de pelo menos duas superfícies de linguagem distintas. Essas superfícies ou camadas podem ser configuradas de forma contraditória ou convergente em direção ao sentido criado. No caso da teatralidade contemporânea, entretanto, elas aparecem de forma antinômica. Ao recorrer à imagem-movimento, as cenas criadas pelo cinema reproduzem a realidade com mais eficácia, liberando o teatro da tarefa de representar o mundo. Portanto, cabe buscar procedimentos propriamente teatrais quando a teatralidade define-se como dimensão artística independente do texto dramático, da impressão de realidade e da tarefa de representar o mundo vivido. Dessa forma, o teatro propõe ao público uma experiência compartilhada, ele será o "leitor" de um mundo inventado, uma organização de seqüências espaço-temporais dotadas de lógica próprias. Algumas vezes, acontecimentos são vislumbrados, outras vezes, o leitor é convidado à contemplação de uma imagem, à reflexão sobre a própria linguagem (metalinguagem) ou à fruição de uma sensação.

Tanto o teatro quanto o cinema voltam-se com freqüência ao objetivo de contar uma estória, incumbência que a própria literatura já não efetua de maneira límpida. A experimentação formal das linguagens possibilita o aparecimento de novos "narradores", citando o famoso texto de Walter Benjamin. Um narrador que apresenta uma obra-ensaio, contando fragmentos de estórias, expondo suas inquietações sobre o fazer artístico e citando seu universo de referências. O narrador contemporâneo coloca-se também como colecionador, independente da linguagem através da qual se expressa. Sua obra abre links, ou janelas, para outras páginas.

O conceito de escritura cênica esboçado por Hans-Thies Lehmann é apresentado pela professora Sílvia Fernandes de forma muito precisa, pois desloca o foco de sua análise para os procedimentos propriamente teatrais, da seguinte forma: 
[...] a qualidade da presença, do gestual e do movimento dos atores, a semiótica dos corpos, as componentes estruturais e formais da língua enquanto campo de sonoridades, o desenvolvimento musical e rítmico do espetáculo, com sua temporalidade própria, e a iconografia dos procedimentos visuais, que, em lugar de ilustrar um texto, compõe 'superfícies de linguagens antinômicas'. (FERNANDES, 2006, p. 14).

É interessante notar como a pesquisadora desdobra os procedimentos teatrais de forma independente, separando superfícies ou camadas da linguagem em aspectos corporais, sonoros, temporais e textuais. É como se cada superfície de linguagem emitisse seu próprio discurso, sem pretender uma unidade, pois não se refere a um universo pré-existente (como acontece com o teatro em que a encenação deve fidelidade ao texto). Portanto, os aspectos formais da cena de cinema (certos procedimentos) nortearão a análise dos filmes e não a observação da diegese (diegético é tudo o que diz respeito ao mundo representado, de acordo com o professor Ismail Xavier).

Até aqui levantamos algumas possibilidades de leitura do cinema como paradigma para o teatro atual, apontando as escolhas às quais nos detivemos. Depois da apresentação de aspectos globais, quase um panorama das possíveis conversas entre cinema e teatro, é hora de estabelecer recortes, nossos "enquadramentos" teóricos.

\section{Observação de filmes brasileiros: um recorte temporal}

Os primeiros filmes analisados nessa pesquisa se inscrevem em um recorte histórico do cinema brasileiro, entre 1965 e 1972. Ao optar por estudar filmes nacionais afirmamos a importância de conhecer parte significativa da filmografia brasileira, responsável pela inscrição de um novo repertório na nossa escrita do visível. Conhecer os filmes de Glauber Rocha é tão importante quanto conhecer as invenções de Zé Celso no teatro brasileiro, seja para estudantes de Artes, seja para estudantes de História do Brasil. Nesse período, posterior ao Golpe Militar de 1964, no qual os filmes selecionados se inscrevem, nomes de peso do cinema brasileiro produziram obras que pensavam a crise dos projetos de esquerda e que se tornaram referência para a criação contemporânea. O intervalo entre 1968 e 1972, os anos mais duros 
da ditadura militar, corresponderam tanto na produção cinematográfica quanto no terreno das outras artes, a um momento de grande experimentação das linguagens impulsionado pelas barreiras impostas pela censura política. Com o cerceamento da liberdade de expressão, principalmente após a instauração do Ato Institucional n.5 (Al-5) em 1968, os artistas buscaram meios de apresentar suas opiniões de forma indireta, para não serem pegos pela repressão. Datam desse período alguns acontecimentos importantes da cultura brasileira:

\begin{abstract}
Os festivais da canção promovidos pelas redes de televisão [...] em 1967. Em 1968, é lançado o disco coletivo Tropicália, nomeado a partir de uma canção de Caetano que, por sua vez, tomava a expressão 'tropicália' de uma instalação de Helio Oiticica, de mesmo nome, no Museu de Arte Moderna do Rio de Janeiro em maio de 1967, época em que Terra em Transe foi exibido na mesma cidade. No teatro, 1967 foi o momento de encenação, pelo Grupo Oficina, dirigido por José Celso Martinez Correa, da peça O Rei da Vela, de Oswald de Andrade; e 1968 foi o ano da encenação de Roda Viva, de Chico Buarque de Holanda, também dirigida por José Celso. (XAVIER, 2001, p. 28-29, grifos do autor)
\end{abstract}

Se o teatro das décadas de sessenta e setenta do século $X X$ não pode mais ser assistido, mas apenas imaginado a partir do que lemos e vemos em fotografias e escassos registros audiovisuais, felizmente o cinema dessa época ainda pode ser visto. No entanto, as gerações atuais têm poucas oportunidades de acesso ao cinema nacional. Aliás, elas têm pouco interesse pelo cinema de seu próprio país, muitas vezes alvo de preconceito da sociedade. O cinema brasileiro ainda tende a ser associado, pelo senso comum, a filmes de baixa qualidade, poucos recursos e apelo sexual, devido a filmes realizados da década de 1980 até início dos anos 1990. Parte das produções atuais, por outro lado, parece empenhar-se demasiadamente em corresponder a um padrão de qualidade imposto por outro contexto social (o norte-americano), afirmando-se como indústria. Por esse motivo, optamos por filmes produzidos no Brasil dentro desse recorte temporal: de 1965 a 1972, e não por filmes atuais.

Para definir com precisão nosso "enquadramento teórico", é preciso justificar a escolha do cinema moderno para a composição de um teatro que se 
aproxima de uma estética pós-dramática. Mesmo sabendo que o teatro que mais se aproxima desse período do cinema é o teatro épico, tal constatação não invalida nossa escolha. O cinema moderno, não só no Brasil, remete a uma pluralidade de tendências. Os "cinemas novos" passaram por diferentes fases de formatação: a proposta original dialogava com o neo-realismo italiano e, posteriormente, houve maior apropriação de procedimentos cinematográficos. Por exemplo, a utilização da câmera na mão é um procedimento que pode ser observado em filmes de ficção de movimentos de diferentes países, constituindo-se inclusive um traço estilístico da época.

Algumas características marcantes do Cinema Moderno por oposição ao cinema clássico e industrial serão elencadas abaixo com o intuito de justificar a escolha do recorte proposto. A utilização de planos-seqüência é notável e interessante para o fazer teatral, uma vez que esses planos longos exigem bastante do ator, seja pela improvisação, seja pela manutenção do jogo cênico, algumas vezes ensaiado. Esse cinema se diferencia definitivamente de um cinema "cheio de cortes", em que o trabalho do ator é praticamente "fabricado" na hora da montagem. Nesses casos, o ator quase não se relaciona com o outro ator, pois as tomadas de cada um deles são feitas isoladamente. Manipular planos longos não significa excluir a montagem, mas buscar resolver a cena de modo sintético, por meio da utilização, por exemplo, da perspectiva. A utilização da profundidade de campo é possível pelo fato de as filmagens acontecerem fora de estúdios, uma opção que alterou significativamente o modo de se fazer cinema. Em um plano-seqüência não é o corte que imprime ritmo ao filme, mas a relação que a câmera estabelece com o ator. Os cortes, todavia, são sensíveis e não há continuidade de movimento entre dois planos consecutivos. A estrutura composta por dois planos, divididos por um corte, não coordena necessariamente dois momentos sucessivos com o objetivo de descrever uma ação, nem representa mudança de espaço. Assim, os cineastas questionavam o equilíbrio da decupagem clássica, recusando justificativas dentro do enredo para o estabelecimento de um corte.

A câmera, nos filmes do período moderno, movimenta-se explicitamente, fazendo-se perceber, já que não pretende criar a ilusão de que observamos a realidade. Os atores, por sua vez, não a ignoram, falam diretamente com os espectadores, executando ações que deixaram de ser uma mise-en-scène 14 
tradicional, pois improvisam também diante das objetivas. Materiais extradiegéticos, que não pertencem ao mundo ficcional, são introduzidos como referência ao universo dos autores.

No quadro atual, quando a nossa atenção se volta para o processo que envolveu o Cinema Novo e o Cinema Marginal entre final da década de 1950 e meados dos anos 1970, tal processo se apresenta como dotado de uma peculiar unidade. Foi, sem dúvida, o período estética e intelectualmente mais denso do cinema brasileiro. As polêmicas da época formaram o que se percebe hoje como um movimento plural de estilos e idéias que, a exemplo de outras cinematografias, produziu aqui a convergência entre a 'política dos autores', os filmes de baixo orçamento e a renovação da linguagem, traços que marcam o cinema moderno, por oposição ao clássico e mais plenamente industrial. (XAVIER, 2001, p. 14)

É importante salientar que todos os filmes aqui selecionados como objeto de estudo representam um momento de sobreposição de dois movimentos: o "Cinema Novo" e o "Cinema Marginal". Pode-se dizer que o recorte escolhido remonta ao período de afirmação do cinema moderno, representando momentos de grande experimentação autoral do cinema nacional em oposição ao cinema-indústria. O "Cinema Novo" estava no apogeu de sua proposta original em 1964, ocasião do Golpe Militar, o que significava apresentar o Brasil autêntico, cujo retrato ideal era o Nordeste, onde a realidade do país saltava aos olhos: o subdesenvolvimento, o regime da terra, a fome. No período pós-64, com a mudança no poder político, aparece a crítica ao populismo. 0 cenário ideal torna-se a cidade, há um diálogo com a tradição literária e questões mais subjetivas referentes à identidade ganham espaço no "Cinema Novo". De modo geral, esse movimento buscava um discurso consciente, sério, engajado politicamente, interessado na situação econômica e política do país. Foi um movimento inaugural, cujos cineastas produziam seus próprios filmes com baixos orçamentos, transformando precariedade em recurso técnico e escolha estética. O conhecido texto de Glauber Rocha, "A Estética da Fome", data desse período. $\mathrm{O}$ autor utiliza a metáfora da fome para referir-se à forma, à construção de um estilo a partir da escassez, e não para fazer um cinema que fale sobre a fome. 
A partir de 1967/1968, com a emergência do Cinema Marginal, juntamente com o contexto cultural explicitado anteriormente, os filmes abandonam a conotação pedagógica e se voltam para uma estética do desencanto, da fragmentação, da colagem, da ruptura, aproveitando a atmosfera tropicalista. Esse desdobramento da "estética da fome" deu origem à "estética do lixo", uma radicalização (e também continuação) do primeiro movimento, rompendo com o público e com os ideais da esquerda e tomando a agressão e o desconforto como princípios formais. Dentro dessa estratégia de agressão e exibindo um retrato infernal e desiludido do país, outros movimentos também despontaram: Udigrudi (versão do Underground norteamericano), "Cinema de Invenção" (escrito como manifesto do cinema experimental, por Jairo Ferreira) e "Cinema Cafajeste" (Cinema Marginal Paulista). Esse cinema da segunda geração era experimental, antropofágico e tropicalista. Buscava um tom menos "sério", mais irônico e escrachado, embora os cineastas tivessem as mesmas inquietações dos cinemanovistas, cujos filmes eram parodiados e comentados pelos marginais. Existem muitas divergências pessoais apartando os movimentos, no entanto, todos eles trabalharam "as tensões entre a ordem narrativa e uma rica plástica de imagens" (Ibidem, p.17). Por isso, optamos conscientemente por não escolher um dos movimentos como recorte para a seleção dos filmes, e sim um recorte temporal, pois notamos a profusão de experimentações e questionamentos presentes na intersecção dessas correntes, que não são apenas duas, mas muitas.

As inúmeras denominações para o tipo de cinema que se fazia (novo, marginal, de invenção, etc) encontram reverberações no polêmico texto "A poesia do novo cinema", de 1965, escrito por Piero Paolo Pasolini. Ele chamou de cinema de "poesia", em contraposição ao cinema de "prosa", o cinema que faz sentir a câmera, o que caracteriza muito bem o estilo de narrativa de cineastas como Antonioni, Bertolucci, Godard e Glauber Rocha. O teórico Christian Metz, no entanto, considera essa sedutora idéia um tanto frágil, pois as noções de prosa e poesia são muito ligadas à linguagem verbal para serem transpostas para o cinema. E ainda discorda de que o cinema moderno seja mais poético. Ao contrário, associa-o ao romance. Metz afirma que "o cinema novo, longe de ter abandonado a narração, nos deu narrações mais diversas, 16 
mais desdobradas, mais complexas" (METZ, 2004, p. 215). A despeito dessa divergência, é unânime que ambos os estudiosos enxerguem nesse momento da história do cinema uma grande fecundidade de invenção e renovação formal da linguagem.

Os filmes selecionados inicialmente foram: "A Falecida" (1965), de Leon Hirszman; "O Bandido da Luz Vermelha" (1968), de Rogério Sganzerla; "O Dragão da Maldade contra o Santo Guerreiro" (1969), de Glauber Rocha; "São Bernardo" (1972), de Leon Hirszman; "Os Inconfidentes” (1972), de Joaquim Pedro de Andrade; "Toda nudez será castigada" (1972), de Arnaldo Jabor, e "São Paulo S/A" (1965), de Luiz Sérgio Person. Nessa coleção híbrida identificamos em Leon Hirszman e Luiz Sérgio Person uma forte referência ao realismo, sendo que os filmes de 1965 (os mais antigos da coleção) se desenrolam em um ambiente urbano. O filme de Hirszman de 1972 volta à tradição literária brasileira, em ambiente rural, enquanto o de 1965 parte do diálogo com o teatro de Nelson Rodrigues. Glauber Rocha, em amostra mais comunicativa e sintética de sua obra, exibe sua alegoria na formalização dos coros, relacionando-se com a cultura popular de modo documental, apesar de se tratar de um filme de ficção. O filme de Joaquim Pedro apresenta muitos recursos épicos (também observados na colagem de estilos de Glauber), inclusive na adaptação literária não convencional que mantém os personagens falando em versos, provocando o distanciamento do público em relação aos personagens. "Toda Nudez" também parte do teatro de Nelson Rodrigues, lida com exatidão com a questão do melodrama e com a passagem da narração para a encenação, sem receio de criar ao lado do grande dramaturgo.

Todos os filmes foram exibidos ao Coletivo - Jogos do Olhar em dois conjuntos de "sessões de cinema" organizados pela pesquisadora no Auditório Paulo Emílio na ECA/USP (as primeiras sessões foram interrompidas pela greve de 2007, por isso outras sessões foram organizadas no segundo semestre do mesmo ano). As sessões eram abertas à comunidade e foram possíveis graças ao apoio do professor Ismail Xavier, que conseguiu as películas de quase todos os filmes emprestadas da Cinemateca Brasileira (exceto as de "A Falecida", que foi exibido em DVD) ${ }^{3}$. Durante o estudo desses

3 Contamos também com a colaboração dos seguintes professores que, gentilmente, conduziram apreciações e debates sobre os filmes após as sessões de cinema: Luiz Fernando Ramos, Rubens Machado (debatendo dois filmes), Sérgio de Carvalho, Ismail Xavier, Rubens 
filmes, orientados pelos professores, alguns filmes e textos analíticos foram citados. Desse modo, uma segunda seleção foi realizada a título de esclarecimento, pois em muitos casos esses filmes eram do mesmo cineasta, ou eram referências para as obras selecionadas anteriormente, ou ainda dialogavam explicitamente com elas. Compuseram a segunda seleção: "Macunaíma" (1969), de Joaquim Pedro de Andrade, "Deus e o Diabo na Terra do Sol" (1964), de Glauber Rocha, "A Mulher de Todos" (1969), de Rogério Sganzerla, "Matou a família e foi ao cinema" (1969), de Júlio Bressane, "Bang Bang" (1971), de Andrea Tonacci e "O Demônio das Onze Horas" (Pierrot le Fou, de 1965) de Jean-Luc Godard.

O filme de Joaquim Pedro é exemplar na combinação da comunicação com o público através da recuperação da chanchada com tom tropicalista. Glauber, no auge da primeira fase do "Cinema Novo", manipula os recursos estilísticos na composição de um cinema ritual. Sganzerla de "A Mulher de Todos" dá continuidade à estética do lixo iniciada no "Bandido", mas dessa vez enfoca a mulher que nasceu para os boçais. Júlio Bressane apresenta, de forma não linear, recortes de estórias, explicitando a disjunção entre imagem e som. Tonacci organiza perseguição bizarra, sem estrutura narrativa clara, descontínua, e faixa sonora que gera desconforto. E por último, o filme de Godard que é explicitamente parodiado por Sganzerla em "Bandido da Luz Vermelha".

O objetivo de um recorte histórico tão abrangente, composto por estilos tão híbridos, era estudar e compreender esse momento crucial de desenvolvimento da cinematografia brasileira. Tal estudo levou à realização de um recorte ainda menor, de apenas dois filmes: "São Paulo S/A" e "O Bandido da Luz Vermelha", embora outros filmes da seleção tenham sido retomados pelos jogadores durante o processo criativo da encenação.

A escolha do primeiro filme ocorreu quando decidimos onde seria a encenação - experimentação prática da pesquisa. O Centro Tecnológico de Hidráulica tinha um grande parentesco com as locações do filme. Em "São Paulo S/A" assistimos ao desenvolvimento industrial das grandes cidades, o mesmo que impulsionou a construção dos modelos físicos reduzidos instalados 
no Laboratório de Hidráulica. Nesse laboratório de ensaio de máquinas, espécie de museu da ciência hidráulica, o tempo parou misturado à água que preenche poças e vãos, lá criou crostas e ferrugens. A amplitude das máquinas, fruto do trabalho do homem em prol do desenvolvimento e da industrialização, nos leva às mesmas indagações que o filme de Person: para onde vamos? Essa pergunta é representada pelo personagem central do filme que em dado momento resolve fugir, sair da engrenagem do sistema pequeno burguês na qual estava inserido. No entanto, o caminhão que o levava de carona devolve-o para o furacão da cidade grande; o mesmo moto continuum que ajudou a produzir, agora o engolia. "São Paulo S/A" é o retrato realista da metrópole na qual os componentes do Coletivo - Jogos do Olhar vivem. São Paulo é a cidade à qual se dedicam muitas críticas e à qual também se dedica, paradoxalmente, grande reverência, pois somente nesse caos urbano a precariedade dos recursos tem espaço para tornar-se expressão artística.

"O Bandido da Luz Vermelha" correspondia às expectativas do Coletivo em relação à construção formal (montagem descontínua, fusão de gêneros, referências do universo pop e comentário paródico) e temática (crise de identidade, desencanto, impotência política e consumismo). O filme é modelar no que se refere à montagem vertical, variações da narrativa, estética do videoclipe e utilização de materiais extradiegéticos, dialogando explicitamente com o Tropicalismo e com outros cineastas, algumas vezes parodiando-os. O modo de produção do filme (com baixo orçamento) coincide também com as condições deste e de outros grupos teatrais brasileiros, independentes e experimentais. De um modo geral, os dois filmes falavam diretamente às inquietações do Coletivo - Jogos do Olhar e constituíam material suficiente para fomentar a elaboração da encenação.

Esses filmes serviram de "modelos de ação" e de "estoque de imagens" para a encenação proveniente dos Jogos do Olhar. Foram escolhidos por concentrarem em suas cenas maior número de procedimentos para serem tomados de empréstimo, ora "experimentados", ora "reproduzidos" na composição das cenas teatrais. Os demais filmes, entretanto, aparecem no panorama temático da encenação, pois se tornaram referência para o agrupamento de jogadores. O filme de Glauber Rocha, "O Dragão da Maldade contra o Santo Guerreiro" serviu de modelo para a criação de algumas cenas, 
no que se refere à estruturação formal. "Toda Nudez Será Castigada", de Arnaldo Jabor estimulou uma das cenas no nível temático. Do filme "A Mulher de Todos", de Rogério Sganzerla, tomamos emprestadas algumas falas.

$\mathrm{O}$ ato de criar uma encenação teatral a partir de filmes dialoga com o conceito de modelo de ação desenvolvido por Bertolt Brecht na produção de suas peças didáticas. Segundo ele, o texto não passa de um pré-texto, cabendo ao jogador o exercício de "historicização", identificação e questionamento desse ponto de partida. Para Brecht, o texto perde o estatuto de "verdade", não limita a cena, mas delimita a superfície de mergulho dos jogadores. De certa forma, a proposta de interação entre as cenas dos filmes e as cenas criadas na pesquisa é convergente com o conceito de Brecht. Logo, procedimentos destacados no filme foram "experimentados" pelos jogadores no espaço teatral. Um exemplo inicial seria a associação da posição da câmera com a posição do público, isto é, se a câmera vê a cena de perto, o público estará perto da cena. Se a câmera vê a cena de cima, o público será posicionado num patamar acima da cena. Essa associação entre câmera e espectador será melhor desenvolvida no capítulo seguinte.

Algumas vezes os jogadores buscaram "reproduzir" as cenas dos filmes; nesse caso entende-se que os filmes foram utilizados como estoque de imagens para a composição teatral. Fotografias e outras obras das artes plásticas também podem ser consideradas estoques de imagem. O cinema torna-se mais um componente para engrossar o caldo de referências dos grupos teatrais durante seus processos de criação. O contato com o cinema pode ser considerado um importante meio de ampliação de repertório, já que "o tamanho da minha linguagem é o tamanho do meu mundo"4

\section{Análise do filme: aproximação dos procedimentos cinematográficos}

A análise dos filmes tem um papel preponderante para a presente pesquisa, pois a criação da cena teatral foi realizada a partir do que foi apreendido pelo olhar dos jogadores. A análise proposta é um debate radical com a forma, enfatizando a observação da sintaxe, ou seja, o modo pelo qual as relações internas são construídas. Para analisar é preciso decompor,

\footnotetext{
${ }^{4}$ Expressão utilizada pelo professor Flávio Desgranges em mesa redonda da Mostra de Licenciatura dos alunos do Departamento de Artes Cênicas da ECA/USP, em dezembro de 2006.
} 
identificar partes, daquilo que é imanente à obra. Trata-se de um exercício de percepção da estrutura formal do filme, entendendo-o como um produto que contém o processo. Segundo o modelo de análise de filmes desenvolvido em sala de aula pelo professor Ismail Xavier, pode-se abordar um filme conjugando dois movimentos: a macro-análise e a micro-análise. Ao observá-lo na sua inteireza (macro-análise), identificamos a trama, como os acontecimentos foram estruturados no corpo do filme, como a fábula, ou a estória, foi contada. Em contrapartida, ao experimentar uma análise parcial, notamos o que é específico à linguagem cinematográfica, no que diz respeito ao estilo (a microanálise). Se alguém se detiver apenas à análise macro de um filme poderia parecer que se refere a um romance, não chegaria a tocar aquilo que é próprio apenas a essa linguagem.

\footnotetext{
O cinema moderno distancia-se do cinema clássico e introduz na sua imagem e no seu som, tal como a vanguarda, uma série de índices que chamam a atenção do espectador para o filme enquanto objeto, procurando criar a consciência de que se trata de uma narração, cujo trabalho começa a se confessar para a platéia. (XAVIER, 2005, p.141).
}

Ao tomar gosto pela descoberta das regras de estruturação do cinema, ver e rever o filme torna-se um exercício de distanciamento para enxergar os mecanismos da composição. O propósito é tornar-se uma esponja do filme, absorvê-lo, como recomendava Paulo Emílio aos seus alunos. Desse modo, conceitos básicos da linguagem cinematográfica foram introduzidos ao grupo de jogadores e algumas cenas dos filmes selecionados foram apresentadas, antes mesmo de serem vistos na íntegra. A escolha por partir da análise da linguagem justifica-se para que $o$ enredo não seja enfatizado. Pedagogicamente, essa solução cumpriu seu intento, porém vale ressaltar que o grupo de jogadores era constituído em sua grande maioria por estudantes universitários, já dotados de formação prévia que provavelmente facilitava a observação formal independente da fábula contada. Sempre que me referir à "apresentação" do filme, estarei me referindo à exibição de algumas cenas escolhidas, para efeito de análise. Tal apresentação serviu como um despertar para o olhar, um apontamento aos jogadores do que observar, munindo-os de algumas referências para que fizessem sua própria leitura da 
composição. Talvez se abdicássemos dessa apresentação, o interesse pelo filme se resumiria ao tema abordado, ou à estória contada por ele, e em última instância, se dariam conta da dificuldade de fruí-los. Nem sempre o contato direto com a obra, sem nenhuma mediação, é a melhor opção, por isso avaliamos as condições da recepção. Pois se no primeiro encontro com o filme, o leitor não tem nenhuma referência para participar do que se constrói diante de seus olhos, ele não terá interesse por ele, considerando-o lento ou cansativo. Por esse motivo, desde a apresentação do filme, busquei revelar o movimento da análise proposta.

A idéia era definir um tipo de análise que nos ajudasse a responder à pergunta-chave da pesquisa: de que modo a leitura de filmes modernos trariam contribuições para os impasses da cena contemporânea? Para responder a essa pergunta, identificamos (não sem a ajuda de Lehmann ${ }^{5}$ ) quatro elementos presentes tanto na cena teatral quanto na cena cinematográfica: Espaço, Corpo, Tempo e Texto. Os elementos selecionados justificam-se pelo seu caráter didático e têm em vista a análise das cenas de cinema voltadas à composição da cena teatral. Entretanto, não se trata de categorias, ou de um suposto estatuto ontológico de toda e qualquer cena. São elementos que podem ser reconhecidos em ambas as linguagens, porém outro pesquisador poderia ter escolhido outros elementos identificáveis nas cenas visíveis. Vale lembrar que essa escolha também se justifica por se tratar de elementos que não se referem a características próprias à ficção, mas àquelas que ressaltam a materialidade das cenas.

A título de esclarecimento, gostaria de citar dois exemplos de autores que se dedicaram à leitura, à identificação de elementos ou componentes e à análise da estrutura teatral. Anne Ubersfeld, em "Para ler o Teatro", parte do estudo do texto dramático e da representação, diferenciando o texto do autor do texto do diretor. A partir de uma análise semiológica, identifica algumas características próprias e específicas à construção do discurso teatral: o personagem, o espaço e o tempo. Patrice Pavis, em "A Análise dos Espetáculos", elenca os seguintes componentes da cena: ator (focado no

\footnotetext{
${ }^{5} \mathrm{Na}$ tradução francesa do livro "Teatro pós-dramático", há um capítulo intitulado "Texte Espace - Temps - Corps", que na tradução brasileira aparece dividido em quatro capítulos. 0 levantamento desses quatro elementos constituintes da cena influenciou intensamente a escolha dos elementos observados na cena cinematográfica.
} 
corpo, no gestual); voz, música, ritmo (o universo sonoro em geral, apesar de reconhecer que desse modo a voz está desassociada "do corpo, do qual é um prolongamento" - PAVIS, 2005, p.121); espaço, tempo, ação (trinômio interdependente, pois não separa espaço e tempo, sem os quais a ação não pode desenvolver-se); outros elementos da representação (figurino, maquiagem, objeto e iluminação). Esses exemplos são importantes referências que lidam com a cena como material, significante, as quais levei em consideração para propor os elementos escolhidos para a análise proposta aqui.

Os elementos (Espaço, Corpo, Tempo e Texto) caracterizam o que há de material e não de fictício na composição cênica, oposição que julgamos relevante apontar. Não se trata de uma escolha ingênua. Optamos por não nos referir à ação, ao personagem e ao espaço fictício, mas por observar esses elementos como signos. Desse modo, a fábula ou a trama do filme não foram observadas, logo os filmes não foram tomados na íntegra (macro-análise). Essa escolha justifica-se pelo fato de não pretendermos reproduzir o enredo do filme na encenação teatral, já que não se tratava de adaptações do cinema para o teatro. Dentro do processo de trabalho do Coletivo - Jogos do Olhar, o roteiro da encenação teatral foi revelado apenas na fase final do processo de criação, momento em que pareceu interessante a realização de uma macroanálise (da encenação teatral, não do filme). Portanto, na busca por descobrir as regras da composição, o olhar que se voltava para o filme agia como um corte que o interceptava verticalmente, retendo-se sobre as escolhas específicas do cinema: o estilo, a micro-análise.

A apresentação do filme constitui-se na exibição de algumas cenas escolhidas, alertando os espectadores para certos procedimentos utilizados em sua elaboração. Geralmente, se iniciava pela exibição dos créditos, quando eles estão no começo do filme, que apesar de sintéticos, resumem em poucas imagens a essência da obra. Em seguida, mostrava cenas emblemáticas das pontes que buscava estabelecer entre as duas linguagens investigadas. Era recorrente, nessa prática, assistir várias vezes a uma mesma seqüência. Inicialmente, sem nenhuma informação; depois, atentando a determinados detalhes e uma terceira vez após observações inesperadas tecidas pelos próprios observadores. Durante a apresentação dos filmes, buscava exemplos 
referentes a todos os elementos (Espaço, Corpo, Tempo e Texto) procurando procedimentos que pudessem ser encaixados nesses pilares da pesquisa. Posteriormente, o Coletivo dividiu-se em subgrupos que buscaram trechos dos filmes que exemplificassem uma das categorias estudadas.

Pode-se imaginar um filme de uma hora e meia composto de um
plano apenas cuja incidência angular seria invariavelmente horizontal
e de frente, sem nenhum movimento de câmara, sem nenhum efeito
óptico (fusão etc), sem nenhuma elipse temporal, sem outra
iluminação que não a uniformemente monótona, sem nenhuma
palavra que não diegética (voz-in), etc. Mas percebe-se que tal filme
teria pouco de cinema - seria mais uma peça de teatro (e até
excepcionalmente linear) registrada por uma câmara.(METZ, 2004, p.
214-215)

Tomando como base o trecho de Christian Metz citado acima, pode-se considerar que a proposta dessa pesquisa seja a criação de um teatro oposto àquele descrito por ele. A visão de teatro do estudioso é justamente a do teatro que não nos interessa; segundo suas próprias palavras, uma peça "excepcionalmente linear". Ao imaginar um filme que seria mais uma peça de teatro, convido o leitor a imaginar uma peça de teatro que seria mais um filme. A citação é propícia para apresentar quais os procedimentos fílmicos foram identificados e levados ao estudo de campo. Referiu-se à incidência angular invariavelmente horizontal e frontal, associada ao ponto de vista do palco à italiana. Nitidamente, o autor refere-se à questão do Espaço, tanto a escolha do espaço físico quanto o modo pelo qual o espaço é recortado e de onde ele pode ser visto.

Portanto, em relação ao Espaço, o primeiro procedimento observado (nos filmes) e posteriormente experimentado (na criação teatral) foi a escolha da locação. O Coletivo - Jogos do Olhar peregrinou por diversos locais da Cidade Universitária, experimentando diferentes "arquiteturas" como locação para o experimento cênico. Fala-se em arquitetura, pois o espaço é um componente determinante na composição da cena de cinema, sobretudo as cenas do Cinema Moderno, por não serem filmadas em estúdios. Por isso, não se cogitou a utilização do palco tradicional, a não ser que o edifício teatral fosse 
tomado como um todo, como uma arquitetura qualquer, sem obedecer à utilização convencional do palco e da platéia.

Ainda no que diz respeito ao Espaço, investigamos a posição da câmera e a associamos ao olhar do público. Os ângulos de enquadramento do cinema sugeriram novos ângulos para o olhar do público, acostumado a ver a cena de frente. Então, os ângulos de observação da câmera: frontal, plongée ou câmera alta e contra-plongée ou câmera baixa - levaram à definição de enquadramentos vistos de frente, de cima e de baixo.

A posição e a movimentação da câmera visam à observação da cena, inserida em um enquadramento do espaço, ou seja, a capacidade da própria câmera de recortar, delimitar o que está presente no seu campo de visão. A observação desses procedimentos refere-se aos elementos Espaço e Corpo em conjunção. Portanto, em cada espaço experimentado, e posteriormente no Centro Tecnológico de Hidráulica (espaço selecionado como locação), associamos a posição e também a movimentação da câmera aos pontos de vista dos espectadores. Entretanto, o olho humano não é como uma câmera, que ao enquadrar exclui o que está fora de campo. Para tanto, utilizamos recortes sugeridos pela arquitetura, que, desvelada pela iluminação, explicitava o "enquadramento teatral" (se assim pudéssemos dizer). Os movimentos ou deslocamentos identificáveis na câmera são panorâmica - a observação geral de um espaço amplo, sem sair do lugar, mas girando no próprio eixo - e travelling, percurso da câmera pelo espaço, deslocando-se em um carrinho. Assim, pesquisamos a movimentação do público de modo a sugerir o movimento da câmera, seja percorrendo uma trajetória de cenas imitando um travelling, seja observando um espaço amplo todo revelado pela iluminação, como em uma panorâmica. No último caso, os espectadores estavam sentados, portanto fixos no próprio eixo, mas girando a cabeça. Seus olhares percorriam o interior da cena guiados pelo deslocamento do foco de interesse dentro dela ou por algum interesse particular. Um grupo de estudantes de Artes Plásticas assistiu à "ISAURA S/A +1 Experimento Hidráulico" e durante a apresentação observava o Laboratório de Hidráulica boquiaberto, sem se ater às cenas instaladas ali. No final da apresentação, disse aos estudantes que o espaço estava aberto à visitação em outros horários, quase ofendida pelo aparente descaso à encenação. Para minha surpresa, eles responderam que 
não tinham interesse em ver o laboratório sem a iluminação e os recortes espaciais propostos pela encenação.

É interessante ressaltar que no teatro (o exemplo acima ilustra isso muito bem), o espectador está sempre livre para mirar onde quiser; diferente do cinema, linguagem que se configura como um olhar construído por alguém. No cinema vemos um álbum de imagens em movimento (literalmente, 24 quadros por segundo), cujas páginas são viradas por um mestre de cerimônias; o artesão da composição cinematográfica faz com que todos vejam a mesma seqüência de imagens. No teatro, cada espectador tem seu ponto de vista e, de fato, vê imagens singulares do ponto de onde observa. É claro que essa afirmação é relativa (depende das dimensões do espaço do público), pois a cena que se dá a ver a todos os espectadores é a mesma, embora haja pequenas alterações dos pontos de onde os espectadores avistam. O que nos interessa, entretanto, é a acuidade na confecção do recorte da cena nesse teatro fora do edifício teatral. Mesmo sabendo que o espectador pode escolher para onde olha, ele não pode ter dúvidas sobre onde queremos que ele olhe, quando o espaço da cena foi demarcado dentro da arquitetura como um todo. Desse modo, não olhar é uma opção dele. Para alcançar esse objetivo, a iluminação teve papel proeminente, buscando qualidades específicas para cada enquadramento escolhido. Uma exceção acontece no caso de haver cenas simultâneas, quando a multiplicação dos focos para o olhar é intencional. Assim, fugimos da iluminação uniformemente monótona descrita por Metz e aprendemos a deixar os espectadores livres para praticarem seus próprios jogos do olhar.

Seguimos a escala de planos, do geral ao close ou plano próximo, para analisar a distância da câmera fixa em relação à cena, exercício que possibilitou variações no enquadramento das cenas teatrais. Durante a análise das cenas filmadas, notávamos, do mesmo modo, a distância entre a câmera e o ator e, conseqüentemente, como ela recortava seu corpo inserido no espaço. Utilizamos a escala de planos, tal qual apresentada pelo professor Ismail Xavier, conscientes de que essa classificação de planos é variável, não se constituindo uma regra rígida (XAVIER, 2005, p.27-28). Apesar disso, parece importante estabelecê-la como definição de um vocabulário comum. 
Plano Geral: em cenas localizadas em exteriores ou interiores amplos, a câmera toma uma posição de modo a mostrar todo o espaço da ação.

Plano Médio ou de Conjunto: uso aqui para situações em que, principalmente em interiores (uma sala por exemplo), a câmera mostra o conjunto de elementos envolvidos na ação (figuras humanas e cenário). A distinção entre plano de conjunto e plano geral é aqui evidentemente arbitrária e corresponde ao fato de que o último abrange um campo maior de visão.

Plano Americano: corresponde ao ponto de vista em que as figuras humanas são mostradas até a cintura aproximadamente, em função da maior proximidade da câmera em relação a ela.

Primeiro Plano (close-up): a câmera, próxima da figura humana, apresenta apenas um rosto ou outro detalhe qualquer que ocupa a quase totalidade da tela (há uma variante chamada primeiríssimo plano, que se refere a um maior detalhamento - um olho ou uma boca ocupando toda a tela).

Ao analisar os filmes, como já dito, partia da seqüência de cenas que corresponde aos créditos, pois ela contém índices a serem desenvolvidos ao longo de todo a obra. "Do ponto de vista formal, um filme é uma sucessão de pedaços de tempo e de pedaços de espaço" (BURCH, 1969, p.24). Um exercício proposto como primeiro movimento da análise, foi a descrição exata das imagens e sons que os jogadores haviam percebido nessa primeira visão do material fílmico. Ao descreverem, os jogadores entendiam que esse trecho sintético já insinuava o filme, como se ele já se anunciasse no fragmento inicial.

Ao dividir o filme em partes, vale ressaltar alguns conceitos. "Cada seqüência seria constituída de cenas - cada uma das partes dotadas de unidade espaço-temporal" (XAVIER, 2005, p. 27). É curioso observar que o conceito de cena empregado pelo professor, embora trate de cinema, vem da tradição teatral. Tais cenas, por sua vez, são decupadas em planos, a unidade mínima do cinema. "O plano corresponde a cada tomada de cena, ou seja, à extensão de filme compreendida entre dois cortes, o que significa dizer que o plano é um segmento contínuo da imagem" (Ibidem, p. 27). A aproximação desses conceitos justifica-se para a compreensão da "decupagem como 
processo de decomposição do filme [...] em planos" (Ibidem, p.27). Portanto, ao falar em roteiro de decupagem, sabemos que se trata da definição prévia da quantidade de planos necessária para a filmagem de determinada cena, variando os ângulos de enquadramento e a distância entre a câmera e o objeto filmado. Posteriormente, tais planos serão combinados no momento da edição e da montagem.

Traduzindo esses procedimentos para a prática teatral, podemos dizer que a concepção das cenas inicialmente como imagens observadas de determinado ponto (como um plano filmado) tenha correspondência com um roteiro de decupagem. Também podemos afirmar que a combinação da seqüência das imagens criadas tenha sido formalizada como roteiro "geográfico", pois se definiu a partir do percurso do público no espaço. Ao definir a ordem e a seqüência de apresentação das cenas, identificamos o que em cinema chamamos de montagem. Tais procedimentos (roteiro de decupagem e montagem) foram analisados segundo o elemento Tempo.

Um exercício proposto ao grupo constituía em dizer em voz alta a palavra "corte" toda vez que o identificassem em uma seqüência observada. Portanto, o corte pode ser considerado um procedimento para a análise e a aplicação na linguagem teatral, que também se refere ao elemento tempo. Para instaurar um corte na cena teatral foi preciso apelar para a iluminação ou para a quebra brusca de foco de atenção dentro da cena. Do mesmo modo, investigamos possibilidades de imobilização, simultaneidade e justaposição nas cenas teatrais (recursos igualmente observados nos filmes), tendo sempre como referência a posição do público, em um local específico ou em deslocamento.

O elemento Texto, por sua vez, foi observado como som e como imagem. Por exemplo, no cinema há uma distinção entre a utilização da voz off e da voz over. Diz-se voz off quando a pessoa que fala está presente no espaço filmado, porém está fora de quadro. A voz over acontece quando o sujeito falante não está presente no espaço-tempo diegético. Dois exemplos são suficientes. A voz dos locutores de documentários que discorrem sobre tudo o que vemos, mas nunca se mostram para o espectador, é um caso de voz over. Também se trata de voz over uma das primeiras cenas de "São Bernardo", de Leon Hirszman, adaptação do romance de Graciliano Ramos. Paulo Honório, personagem vivido pelo ator Othon Bastos, está sentado numa cadeira diante 28 
de uma mesa, realizando pequenas ações silenciosamente. Enquanto isso, ouvimos sua voz narrando a primeira página do romance, praticamente na íntegra. Então, apesar do ator estar presente em cena, ele não fala em cena, fala fora dela. A narração em primeira pessoa causa a impressão de que ouvimos seu pensamento, utilizando de maneira magistral o recurso da voz over. O cineasta assume a presença da literatura em cena, sem ser encenada, ou antes, sem sucumbir à tentação de encená-la.

Logo, o texto pode ser manipulado pela voz de maneiras variadas, dentro da cena (in), fora da cena (off) e, por meio do registro em áudio de uma voz que não está na cena (over). Em relação ao texto, dentro da composição da imagem, pode-se observá-lo como materialidade visual, podendo estar impresso, grafado ou projetado na cena. No que se refere à análise da trilha sonora, podemos identificar música, ruídos e efeitos, além da utilização da voz. Pode-se ainda investigar sons produzidos no espaço, a partir da manipulação de objetos presentes na locação e das modulações da voz diante de diferentes superfícies. Outra possibilidade seria partir da alteração do foco sonoro dentro do espaço, ou seja, a exploração de posições distintas para a emissão de um som realizado pela voz ou pelo choque de objetos encontrados no local.

Para desvendar a materialidade do filme, buscamos identificar certos procedimentos cinematográficos referentes aos elementos Espaço, Corpo, Tempo e Texto inerentes a sua composição audiovisual. A análise cinematográfica foi considerada não só o primeiro jogo do olhar, mas o jogo que permeou toda a escritura da encenação. Após a identificação do procedimento fílmico, ele era transposto para o universo da criação teatral. Entretanto, mantivemos o filme sempre à mão. Assim, poderíamos retornar a ele, consultá-lo inúmeras vezes, tornando a análise do filme um jogo recorrente.

Ao propor que a linguagem cinematográfica influenciasse o teatro, dois comentários/perguntas dos participantes do Coletivo eram recorrentes: "Não seria o contrário, não é o teatro que veio antes do cinema e o influenciou?" Ou, "realmente, a maioria das peças recentes usam vídeo em cena." Além da possibilidade de se utilizar o vídeo em cena, de se dispor de tecnologia no espaço teatral, interessa aqui a influência do cinema enquanto forma de construir procedimentos cênicos e de instaurar um modo de narrar 
contemporâneo. As técnicas do cinema alimentam as encenações teatrais, de maneira mais ou menos explícita, desde a composição até o empréstimo das nomenclaturas. Hoje em dia fala-se em roteiro, ponto de vista, corte, simultaneidade, partitura de imagens e de sons, etc. Sem que se perceba, o discurso cinematográfico, eminentemente imagético, toma conta das criações teatrais. A invasão do cinema pode ser percebida na mudança do modo de produção do discurso: a imagem toma o lugar da palavra no levantamento de materiais para a cena.

Apresento abaixo um exemplo de encenação teatral que chegou à cidade de São Paulo no ano de 2007 em que se utiliza um material audiovisual como citação. Esse material colabora para a composição de uma narração híbrida, que fala por meio de palavras, cenas teatrais e cenas televisivas. Nessa encenação também podemos identificar procedimentos cinematográficos "camuflados" no modo de olhar e conceber a cena teatral.

"A Gaivota", da Cia. dos Atores, encenação de Enrique Diaz:

Essa encenação é um exemplo de teatro contemporâneo que se deixa influenciar pelas novas tecnologias, utilizando o vídeo para propor um deslocamento espacial do contexto histórico da narrativa apresentada. O vídeo exibido na encenação apresenta trechos de telenovelas brasileiras, sendo que o texto foi escrito em 1896 na Rússia. A discussão da peça gira em torno dos modos de produção: grupos experimentais de criação coletiva (situação da própria Cia. dos Atores) x modos de produção associados à indústria cultural (em especial, a televisão). Apesar de se tratar de um texto de Tchekhov e de haver todo o século XX entre a escrita da peça e a encenação da Cia. dos Atores, a questão levantada pela obra continua pertinente: o tempo e suas possibilidades de transformação e continuidade. Há na releitura desse clássico um belo exercício de metalinguagem, como resposta ao exercício de Tchekhov: atores debatem o teatro do seu espaço/tempo.

Os atritos entre gerações são incorporados em dois personagens: mãe e filho. A mãe vivida pela atriz Mariana Lima é uma diva esquecida dos palcos de 30 
Moscou; a atriz que a interpreta, por sua vez, participou de telenovelas da Rede Globo. Numa atitude assumidamente crítica às "divas" de nosso tempo, imagens de Mariana Lima na TV Globo são exibidas em vídeo para exemplificar o percurso da personagem de Tchekhov. A Cia. dos Atores se propõe a discutir o teatro do seu tempo, identificando-se com as indagações do filho (Anton Treplev). O paralelismo proposto pela encenação, entre a grande a atriz do Teatro de Moscou e as atrizes-celebridades eleitas pela televisão, é uma crítica bastante ardente, que provoca risos na platéia. A utilização do material audiovisual pode ser justificada pelo enredo, pela fábula contada (ela poderia estar vendo um álbum de fotografias) e pela trama (modo de contar). Porém a encenação também dialoga com a estética audiovisual no nível do estilo: a cena pode ser visada de três pontos de vista (três arquibancadas), de diferentes ângulos de enquadramento, do frontal ao plongée (câmera alta) e explora, com a movimentação dos atores, profundidades de campo diversas, causando impressão de que se observa ora planos gerais, ora planos próximos.

\section{Análise como treino do olhar - o estímulo para a formação do Coletivo}

"Tudo o que vejo por princípio está ao meu alcance, pelo menos ao alcance do meu olhar, assinalado no mapa do 'eu posso'." Merleau-Ponty

A apresentação da coleção inicial de filmes aconteceu paralelamente ao agrupamento de pessoas em torno do projeto. Ciente dos meandros que envolvem a composição de um grupo de pesquisa, mesmo que temporário, por isso chamado de Coletivo, propus alguns encontros para a apresentação dos filmes como amostra de como lidaria com esse material. Nessas ocasiões, explicava os pontos de partida da pesquisa, exemplificando com o estudo de algumas cenas cinematográficas. Muitas pessoas passaram por esses encontros, ouviram meu convite de configuração de um Coletivo e participavam da apresentação de um filme que começava a ser analisado. Entrelaçar esses dois momentos, estudo de cinema e configuração do Coletivo, foi um modo de atrair interessados que gostassem de cinema e quisessem fazer teatro.

A realização dessas reuniões foi proveitosa por alguns motivos. Primeiro, por me fazer repetir os objetivos da pesquisa, certificando-me de minhas 
escolhas e convidando outras pessoas para se aventurarem nesse exercício de "leitura" do cinema e "escrita" do teatro. Depois, para compreender a parcela de sedução que está envolvida no processo pedagógico. Trata-se de um jogo em que o meu envolvimento é o melhor convite para o envolvimento do outro. $E$ por fim, o fato de colocar-me em situação de aprendizagem, expondo meu processo de estudo e descoberta da linguagem cinematográfica, aproximou o grupo de jogadores da coordenação do projeto. Apesar de todos estarem em situação de aprendizagem e de criação, como sujeitos de seu conhecimento e criadores de sua arte, as funções estavam claramente definidas: a professoraencenadora, os jogadores, a fotógrafa, a iluminadora, o figurinista. Como não tenho formação em cinema, agi como o "mestre ignorante" de Jacques Rancière, o professor que ensina o que não sabe, pois sua função é despertar a vontade de aprender e não transmitir um conhecimento armazenado. Ao expor meu processo de estudo e revelar os caminhos da pesquisa, uma das jogadoras afirmou que o processo de criação e aprendizagem tal qual o vivenciamos revelava os procedimentos de forma transparente, sem segredos, nem saídas geniais.

Acredito que revelar o pensamento subjacente à pesquisa seja uma forma de democratizar o conhecimento. Desse modo, ao explicitar o movimento da análise, a forma de manusear o material fílmico, possibilitava que os jogadores se apropriassem dele. Essa conduta de explicitar os procedimentos rendeu muita discussão em torno dos princípios que nos guiavam. Uma questão determinante do tipo de trabalho desenvolvido foi a opção por chamar o agrupamento de pessoas envolvidas na pesquisa de Coletivo e não de Grupo. Um grupo não é formado de imediato, depende de um desenvolvimento no tempo, como se de repente as pessoas percebessem que estão sendo, agindo como um grupo. Por isso não gostaria de impor essa condição (sermos um grupo!) para que pessoas desconhecidas trabalhassem em conjunto. Não gostaria que essas pessoas se sentissem convidadas a ficarem juntas para a realização de outros projetos; se isso acontecesse, seria um movimento natural. Entretanto, inúmeras vezes nos perguntamos: é só um novo nome? O novo nome pressupõe quais mudanças nos modos de produção?

A idéia de coletivo de artistas é muito comum nas artes plásticas, de onde as artes performáticas tomaram emprestado o conceito. Geralmente, os 32 
coletivos se reúnem com o intuito de ocupar determinados espaços ou discutir temas de interesse comum. No Dicionário Houaiss da Língua Portuguesa a definição de coletivo "compreende ou abrange muitas pessoas ou coisas", "pertence a um povo, a uma classe, a um grupo" (HOUAISS, 2001, p. 760). Do latim collectivus significa aquilo "que agrupa, ajunta". A palavra "coletivo" é apresentada como antônimo de individual.

A configuração de um Coletivo possibilitou que um amontoado de gente vivenciasse uma experiência comum, descobrindo outros modos de estar junto. Não substitui a vivência em grupo, trata-se de outra formatação. As pessoas escolhem trabalharem juntas não por identificações anteriores, mas por um objetivo específico: uma "empreitada". Com um foco de interesse (estudar o cinema para se fazer teatro), a pesquisa poderia agregar grupos e artistas individuais e num tempo pré-estabelecido desenvolver a encenação. Um coletivo sobrevive o tempo que dura a empreitada, tem hora de começar e de acabar. Propõe uma circulação maior de parceiros, não permite uma construção lenta de relacionamentos, sedimentados ao longo dos anos, tal qual o grupo oferece. Entretanto, não está distante de um grupo no que diz respeito a envolvimento e dedicação. Trata-se, portanto de uma estrutura mais fluida. Se o grupo fosse um casamento, o coletivo seria um namoro, um convite a enlaces mais temporários, sujeito a repetições e reorganizações de tempos em tempos.

Após experimentarem esse Coletivo, embora tristes pela separação dessas pessoas agora "queridas", alguns deles estabeleceram novas parcerias, reativando elos iniciados no Coletivo - Jogos do Olhar. No final do processo, verificamos a importância de realizar projetos com ponto final, pois assim podemos avaliar com mais clareza nossa vontade de permanecer juntos e desenvolver um projeto comum. Muitas pessoas nos perguntaram: o grupo continua? E ficavam muito decepcionadas diante da resposta negativa. Essa atitude endossa a constatação das expectativas em relação aos grupos comparadas ao casamento. A principal característica dos grupos bem sucedidos é permanecerem juntos, apesar das diferenças e dificuldades, em uma formatação duradoura. Esse modelo de grupo estável, com atestado de qualidade garantido pelo tempo de trabalho tem um papel muito importante na organização dos artistas enquanto classe de trabalhadores. Da mesma 
maneira, participar de um grupo é um meio de inserir-se no mercado das artes. No entanto, algumas vezes esse "nó" permanece atado apenas na figura do diretor ou de um número restrito de integrantes em torno dos quais gravitam atores passageiros. A nomenclatura (grupo) e a contagem do tempo, entretanto, permanecem, provavelmente porque o tempo de sobrevivência dos grupos conta pontos a favor na luta pelos editais de cultura.

Essa experiência aponta para a possibilidade de novas formatações. Espero que o formato de Coletivo aqui proposto não se confunda com agrupamentos teatrais apoiados em processos curtos que valorizam exclusivamente a qualidade e a comercialização do produto, em processos criativos "industriais". Os Coletivos podem apresentar-se como saída para organização de agrupamentos temporários em Casas de Cultura e C.E.U.s. Geralmente, nesses contextos, fala-se em formação de grupos, mesmo que poucos realmente se sustentem com o decorrer do tempo. Atualmente, a formação de grupos está associada a valores quantitativos exibidos pelos governantes como prova de apoio à cultura e não à qualidade e manutenção da prática desses agrupamentos. No ambiente da Universidade, em cursos profissionalizantes e em oficinas de teatro, a configuração de grupos é uma conseqüência não qualificável (ser bem ou mal sucedido), pois enquanto essas pessoas estão sob o estatuto de alguma instituição são classes, ou turmas, não necessariamente grupos.

Estender essa possibilidade para instâncias profissionais é um passo além para acolher artistas independentes e dar voz a pequenos grupos incapazes de se projetar sozinhos. A configuração de Coletivos revela-se como estratégia de fortalecimento de grupos pequenos, desconhecidos e excluídos dos editais públicos. Com a proliferação de grupos na cidade de São Paulo, modelo de ação cultural para outras capitais do país, não há espaço para todos no mercado de trabalho, mesmo com a abertura de novos editais de cultura. Por isso, para garantir a sobrevivência de Coletivos, entendido aqui como organização temporária, torna-se necessária a adequação dos editais públicos. Sob esse ponto de vista, os Coletivos constituiriam uma alternativa para a organização política da classe artística. 


\section{Coleção de Jogos do Olhar}

Apresentamos a seguir a primeira lista de jogos que compõem a Coleção intitulada "Jogos do Olhar". Os jogos descritos abaixo se referem a propostas desenvolvidas com o intuito de se ler a cena cinematográfica. Ambos foram retirados do contexto de aulas em que se analisava filmes.

\section{Descrição de seqüência fílmica:}

Após observar uma seqüência de imagens e sons, geralmente os créditos do filme, sugerir que os jogadores descrevam o trecho por escrito. Escolher realizar o exercício com os créditos do filme leva os jogadores a perceberem as características formais da linguagem, uma vez que durante a apresentação dos créditos a estória ainda não começou a ser contada. Essa descrição serve para o professor analisar a qualidade da observação dos jogadores, verificando se eles se detêm somente as informações visuais ou se percebem também os sons ou músicas presentes no recorte. Também se pode notar qual o grau de apreensão do leitor no que diz respeito à composição dos fotogramas, caso haja algum deles que se destaque dos demais, por exemplo, exposto como imagem estática, imobilizado.

\footnotetext{
Identificação de cortes:

Escolher trecho do filme e convidar os leitores a falar (em voz alta) a palavra "corte" toda vez que identificarem a ocorrência de um corte. No Cinema Moderno, sobretudo, os cortes são bastante sensíveis, pois não há a intenção de se esconder nem a câmera, nem os procedimentos da linguagem. Pela utilização de planos-seqüência (planos longos, sem cortes) nos filmes desse período, o espectador notará que a cena, muitas vezes, sustenta-se pelo jogo entre os atores e não necessariamente pela montagem. Identificando os cortes, o leitor poderá discutir a montagem das cenas, analisando o posicionamento das imagens e dos sons ao longo do tempo na composição do filme.
} 


\section{ANEXO I}

1. Cartaz convite para participação do Coletivo - Jogos do Olhar, foto e arte de Marina Takami

2. Cartaz da $1^{\text {a }}$. Sessão de Cinema dos Jogos do Olhar, foto e arte de Marina Takami

3. Cartaz da $2^{a}$. Sessão de Cinema dos Jogos do Olhar, foto e arte de Renata Velguim 


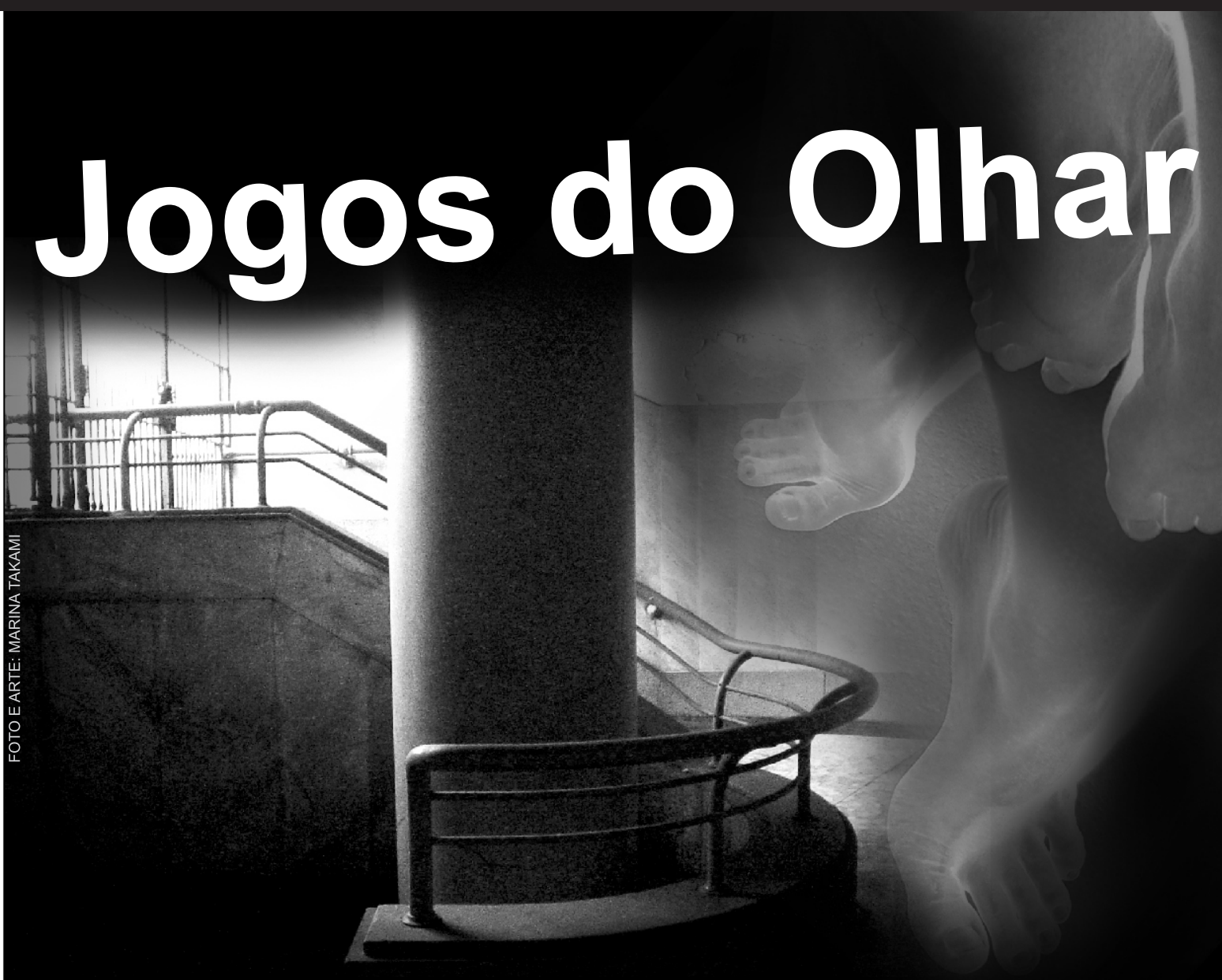

COORDENAÇÃO

VERÔNICA VELOSO mestranda

Artes Cênicas-ECA/USP INSCRIÇÕES ABERTAS para maiores de 17 anos Local dos encontros Dep. Artes Cênicas ECA/USP

INFORMAÇÕES

(11) 8447 - 0878

jogosdoolhar@gmail.com

PARTICIPE DO PROJETO Jogos do Olhar uma encenação teatral

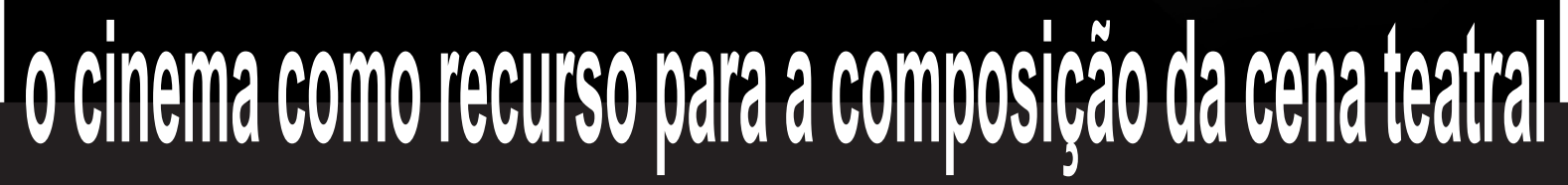
observação de cenas cinematográficas 
Sessões de cinema da oficina Jogos do Olhar

\title{
programação
}

\author{
18/04 - A FALECIDA (1965), DVD \\ de Leon Hirszman \\ - debate Prof. Luiz Fernando Ramos (CAC/ECA) \\ e Reinaldo Cardenuto (mestrando ECA)
}

25/04 - O DRAGÃO DA MALDADE CONTRA O SANTO GUERREIRO (1969)

$$
\text { de Glauber Rocha }
$$

- debate Prof. Rubens Machado (CTR/ECA) e Paula Klein (mestranda ECA e Cia. SJorge de Variedades)

02/05 - OS INCONFIDENTES (1972) de Joaquim Pedro de Andrade
- debate Prof. Sérgio de Carvalho (CAC/ECA e Cia.do Latão) e Adilson Inácio Mendes (mestrando ECA)

de 18 de abril a 23 de maio

09/05 - SÃO BERNARDO (1972) de Leon Hirszman
- debate Prof. Ismail Xavier (CTR/ECA) e Pedro Plaza (doutorando ECA)

(quartas-feiras)

às $19 \mathrm{~h} 30$

Auditório Paulo Emílio

(20. andar do prédio central da ECA/USP)

16/05 - TODA NUDEZ SERÁ CASTIGADA (1972)
de Arnaldo Jabor - debate Prof. Rubens Rewald (CTR/ECA) e Pedro Granato (IVO 60) 


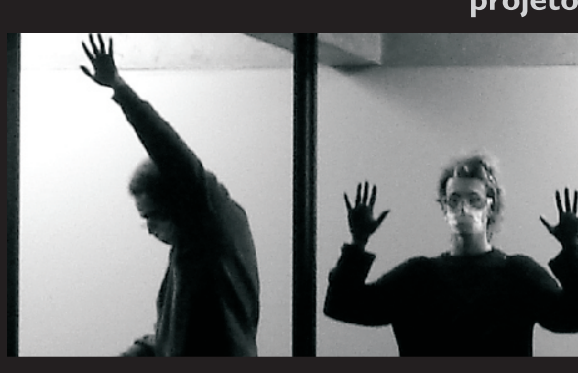

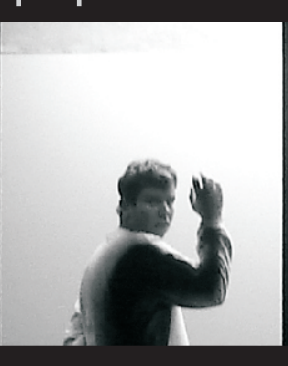

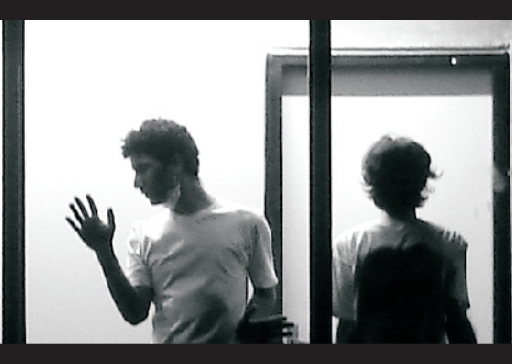

I5/08 - TODA NUDEZ SERÁ CASTIGADA

De Arnaldo Jabor

-Debate Prof. Rubens Rewald (CTR/ECA)

E Pedro Granato (IVO 60)

sessões de cinema da oficina

JOGOS DO OLHAR

22/08 - O BANDIDO DA LUZ

29/08 - SÃO PAULO S/A

De Luiz Sérgio Person

-Debate Prof. Rubens Machado (CTR/ECA)

E coletivo Jogos do Olhar

15, 22 e 29 de agosto às 19h30 - Auditório Paulo Emílio - $2^{\circ}$ andar do prédio central da ECA/USP
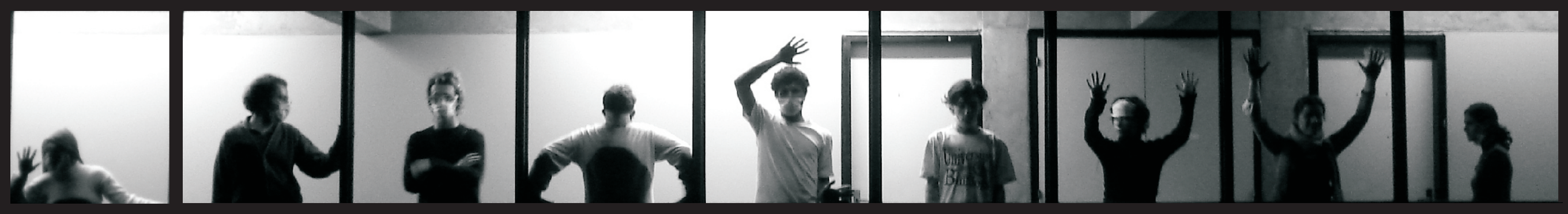

agradecimentos Ismail Xavier, Maria Lúcia Pupo e Joel Yamaji. fotos e cartaz Renata Velguim. ensaio Jogos do Olhar na Hidráulica. 


\section{Termo de Compromisso}

Ao optar por realizar essa encenação em um espaço que não é destinado oficialmente para eventos artísticos, convidamos o público a uma atitude mais ativa diante da obra de arte. Para acompanhar esse Experimento, o público deverá permanecer atento para percorrer um trajeto indicado pelos atores. É um espaço amplo, cheio de desníveis e fendas. Em alguns momentos, estará pouco iluminado, por isso procurem pelas lanternas da equipe que ajudará na condução.

Esse Termo de Compromisso é apenas uma medida de precaução, para que todos saibam de antemão o tipo de experimento que vão assistir e assumam os riscos de acompanhar o Coletivo - Jogos do Olhar nessa experiência de ressignificação do espaço da ciência.

Assinem esse termo de compromisso e participem desse evento hidráulico!

Responsabilizo-me por todo e qualquer acidente que ocorrer comigo nas dependências do Centro Tecnológico da Hidráulica.

\section{Assinatura}

Celular (se estiver com ele no momento):

Data: 


\section{Capítulo 2: Recorte Fotográfico - Composição de Imagens Estáticas}

"Este grande silêncio visual que eu amo". Clarice Lispector

O presente capítulo apresentará duas categorias de Jogos do Olhar utilizadas na composição de imagens estáticas: Espaço e Corpo. Tanto Espaço quanto Corpo são categorias que se traduziram na prática como Módulos de Trabalho. Por isso, além de nos referirmos a esses elementos como categorias abordadas em várias etapas da criação, também usamos o termo Módulo quando nos referimos à experimentação prática.

Discutiremos a composição da cena estática, vista por um observador fixo, em um recorte de espaço arquitetônico, tal qual uma fotografia viva (un tableau vivant). Consideramos a imagem como unidade mínima da composição da cena, à semelhança do fotograma cinematográfico. Portanto, nessa proposta de escritura teatral, a imagem é inicialmente estática como um fotograma retirado da faixa de imagem de um filme. Citaremos os procedimentos cinematográficos observados para a seleção ou a elaboração dos jogos relativos ao Espaço, uma vez que os jogos para estudo do Corpo não foram diretamente influenciados pelo cinema.

O Coletivo - Jogos do Olhar peregrinou por diversas locações da Cidade Universitária, explorando recortes fotográficos em diferentes arquiteturas. Ao olhar e experimentar as arquiteturas, procedimentos cinematográficos foram emprestados do cinema para a seleção e elaboração dos jogos relativos à categoria Espaço. No que diz respeito à categoria Corpo, selecionamos jogos de fontes diversificadas, decorrentes do percurso teatral da pesquisadora, tais como: proposta de treinamento do ator elaborada por Lu Carion a partir da Técnica Klauss Vianna, alguns jogos apreendidos com o ator Sotigui Kouyaté e outros propostos por Jean-Pierre Ryngaert e descritos pela pesquisadora Carmela Soares em dissertação de mestrado (UNIRIO, 2003). Além disso, alguns jogos foram elaborados em função das necessidades reveladas na interação do corpo com o espaço.

Para finalizar, traçaremos um paralelo entre um momento do processo criativo (busca pela locação) e a configuração do Coletivo. É importante ressaltar que no presente capítulo trataremos de imagens estáticas, 
"fotogramas" teatrais, que antecedem a criação da cena dotada de movimento. A criação de imagens teatrais em movimento, inspiradas nos planos cinematográficos, será tratada apenas no próximo capítulo.

\section{Arquitetura como espaço cênico}

O espaço retém o tempo comprimido.

Gaston Bachelard

Patrice Pavis considera o Espaço um dos componentes da cena, juntamente com o tempo, o ator, a voz, a música, o ritmo e a ação. Em seu "Dicionário de Teatro" encontra-se a noção de espaço praticamente esmiuçada, de acordo com diversos aspectos, do texto à representação. Em um dos primeiros protocolos ${ }^{6}$ do Coletivo, a iluminadora Taty Kanter trouxe essa teoria para a roda. Apresentou a definição de seis tipos de Espaço: o espaço dramático é aquele do qual o texto fala; o cênico é aquele onde os atores evoluem, mesmo que seja no meio do público; o cenográfico ou teatral abarca o espaço onde se encontram a cena e os espectadores; o textual refere-se à materialidade do texto, seja ela sonora, gráfica ou retórica; o gestual ou lúdico é descrito pelo corpo do ator e o interior é imaginado, ou seja, uma visão, um sonho, uma fantasia representado pelo personagem ou pelo dramaturgo.

De acordo com a terminologia acima, optamos pelo termo espaço cênico quando nos referimos aos espaços explorados pelo Coletivo de jogadores. Seguindo assim as considerações tecidas abaixo por Patrice Pavis (PAVIS, 1999, p, 133)

\footnotetext{
Considerando-se a explosão das formas cenográficas e a experimentação sobre novas relações palco-platéia, espaço cênico vem a ser um termo cômodo, porque neutro, para descrever os dispositivos polimorfos da área de atuação.
}

Algumas vezes nos referimos ao espaço como "arquitetura" com o intuito de enfatizar a possibilidade de transformação de todo e qualquer edifício em

\footnotetext{
${ }^{6}$ Protocolos são instrumentos do processo de aprendizagem destinados ao registro e à reflexão sobre cada encontro e, sobretudo, à propulsão da investigação coletiva. Podem ser realizados por um integrante, uma dupla ou todos os integrantes do grupo. Essa é uma maneira de incentivar a percepção de que todos são agentes conscientes do processo de criação e aprendizagem. (ver KOUDELA, 2001, p.86-93)
} 
espaço cênico. Em função do diálogo com o cinema, às vezes, utilizamos o termo "locação teatral".

As locações de todos os filmes analisados eram espaços arquitetônicos reais: a cidade ou o interior de edifícios. Esses filmes não foram rodados em estúdios ou em cenários que arremedam espaços reais, o que nessa tradução de linguagens corresponderia ao palco à italiana com sua parafernália cenográfica. O que se espera do espaço nessa pesquisa é que ele seja inspirador por si só, sem necessidade de complementos, de cenários sobrepostos.

O teatro contemporâneo invade os espaços públicos, não convencionados como teatrais, firmando-se no pacto de que qualquer espaço pode ser transformado em espaço cênico. O que garante a transformação de um espaço qualquer em espaço cênico é o pacto teatral, acordo tácito perceptível no jogo dos atores com o público. Dependendo do tipo de performance desenvolvida pelos atores, esse pacto é mais ou menos visível ${ }^{7}$. Os espaços utilizados pelo Teatro da Vertigem, nas encenações de Antônio Araújo, serviriam perfeitamente como locações para uma filmagem. Tais encenações foram concebidas e apresentadas em espaços como uma igreja ("O paraíso perdido"), um antigo hospital ("O livro de Jó”), um presídio desativado (“Apocalipse1, 11"), e mais recentemente, às margens e ao longo do rio morto - o Rio Tietê ("BR 3").

$\mathrm{Na}$ história do cinema também houve uma mudança significativa de espaços, representada inicialmente pelo neo-realismo italiano e, posteriormente, pelo movimento do cinema francês intitulado Nouvelle Vague. Pode-se dizer que o espaço arquitetônico tornou-se o espaço por excelência do cinema moderno, época em que os diretores de cinema começaram a rodar seus filmes fora dos estúdios. Outro fator que colaborou imensamente para a invasão dos espaços urbanos pelo cinema foi o aprimoramento tecnológico das câmeras, que se tornaram menores e mais leves.

\footnotetext{
${ }^{7}$ No caso da encenação realizada pelo Coletivo - Jogos do Olhar, os espectadores chegavam ao Centro Tecnológico de Hidráulica cientes de que assistiriam a uma encenação teatral. $O$ público inclusive era convidado a assinar um termo de compromisso responsabilizando-se por suas atitudes no local, respeitando as regras propostas pelo Coletivo e assumindo os riscos de eventuais acidentes que poderiam ocorrer no local (termo no ANEXO II).
} 
O dicionário Houaiss da Língua Portuguesa define arquitetura da seguinte maneira: "arte e técnica de organizar espaços e criar ambientes para abrigar os diversos tipos de atividades humanas, visando também a determinada intenção plástica" (HUAISS, 2001, p. 294). Pensando na relação do homem com a arquitetura, Le Corbusier afirma que a arquitetura abandonou o luxo, na medida em que passou a ocupar-se da casa comum e habitual para o homem normal, todo e qualquer homem. A mudança de foco do palácio para a casa revela o percurso da arquitetura que se ocupa de vestir, passando por uma que se ocupa de servir (a casa como "máquina de morar"), chegando àquela interessada em emocionar. É exatamente isso que esperávamos da arquitetura: que ela despertasse emoções ao emprestar-se para a ressignificação. A instalação de cenas nessa arquitetura não oficial descola do espaço seu sentido usual, o que leva aqueles que a contemplam a refletir sobre a função e os sentidos pré-estabelecidos aos lugares. Conscientes das funções dos locais visitados, mecanismos para observar, experimentar e fruir essas arquiteturas foram desenvolvidos a ponto de permitir que elas nos emocionassem.

\begin{abstract}
A transformação simbólica dos espaços urbanos causava grande interesse no grupo, em razão dos fortes contrastes entre sua significação cotidiana e as possibilidades subversivas de refuncionalização inerentes ao jogo. (MARTINS, 2003, p.76-77). ${ }^{8}$
\end{abstract}

O espaço pode ser observado plasticamente, como combinação de superfícies, paredes e sombras, compondo ambientes. Entretanto, a vivência de um espaço introduz informações sobre sua memória e sua função. Muitas informações ocultas emanam dos lugares através do modo como as pessoas vêem, utilizam e referem-se a eles. Por exemplo, há no edifício teatral uma aura particular. Independente da peça apresentada, sentimos o cheiro do teatro, vemos as cortinas e as poltronas. Imaginamos quantos espetáculos foram apresentados ali, desencadeando sentimentos diversos e numerosos. Ouvimos estórias desenroladas nesse ambiente, notamos como agem e pensam as pessoas que trabalham no local. Pode-se dizer também que a aura

\footnotetext{
${ }^{8}$ Ao narrar as experiência da Tribo de Teatro Tumutupugá, Marcos Bulhões poderia estar narrando as experiências do presente Coletivo. Como a pesquisadora atuou nessa Tribo, é difícil delimitar com clareza as influências de Marcos na atual pesquisa; ele foi formador, orientador, inspirador. O que se desenvolve aqui é um desdobramento de seu estudo.
} 
de uma igreja é diferente da aura de um cemitério, assim como a aura de cada teatro é diferente uma da outra. Não sei se a palavra "aura" é a mais indicada para o que pretendo expressar ao referir-me às sensações vividas, às histórias e aos sentimentos retidos no lugar ou no objeto. O professor de Do-Ho (treinamento de origem japonesa, que significa "Caminho para o Movimento") Toshiyuki Tanaka diria "yuki" para se referir ao que nomeei de "aura" dos espaços, conceito que ele estende também para as roupas. Para ele, uma roupa de ensaio usada várias vezes tem yuki, uma roupa nova, não; e cada espaço, como casa, igreja, teatro e parque têm yukis diferentes. Por esse motivo, mais do que visitar cada lugar, foi preciso experimentá-lo, vivenciar jogos, permanecer no local por algum tempo, reconhecer seu cheiro e perceber o que cada espaço tinha para nos contar.

O que há em comum dentre os espaços selecionados é o fato de terem recebido a influência do homem, como arquitetura e como continente de vivências humanas, durante certo período de tempo. Isso ficou refletido na experiência do Coletivo ao transformar espaços quaisquer em arquitetura própria ao teatro. De certo modo, no processo criativo tal qual propomos, o espaço acaba sussurrando os temas que serão tratados, uma vez que é sua configuração que inspira os jogadores a ressignificá-lo.

Ao falar em arquitetura teatral, Anne Ubersfeld "sonha" (segundo as palavras da autora) com uma tipologia dos espaços teatrais construídos a partir do espectador, do referente ou pela relação com os atores. Ao transformar arquitetura em espaço cênico torna-se necessário enfatizar o primeiro tipo de espaço descrito pela autora, aquele construído a partir do espectador (UBERSFELD, 2005, p. 116):

\footnotetext{
Esta perspectiva supõe uma visão geométrica do espaço, uma geometrização da cena; ainda que essa geometria corresponda a modelos totalmente diferentes (perspectiva do teatro à italiana, teatro clássico, teatro antigo, teatro chinês, teatro elisabetano), o que importa é a relação entre as diversas áreas de atuação e, nestas, o movimento que o investem. A arquitetura cênica é determinante para o funcionamento dos espaços em função do olhar do espectador.
}

A autora define o espaço teatral como a resultante da combinação de uma arquitetura, de pontos de vista quase pictóricos e de espaços esculpidos 
pela movimentação dos atores. A constatação de Ubersfeld afirma a independência do teatro do palco convencional do edifício à italiana. A formatação dessa arquitetura teatral corresponde à descoberta da perspectiva, constituindo um marco histórico tanto na representação pictórica, quanto na representação teatral. Na sala à italiana, o lugar do público está definido pela arquitetura; essa formatação constitui-se como o espaço tido como ideal para a visualização da cena, o que pode ser considerado um ganho para a história do teatro. No entanto, atualmente, as artes plásticas já ultrapassaram as questões relativas à perspectiva e à representação da realidade, aproximando-se das artes performáticas. Como já dissemos, o cinema encarrega-se muito bem de representar a realidade. Além disso, as novas tecnologias audiovisuais estão presentes em muitos espaços da vida cotidiana, são os tempos dos reality shows, da sociedade do espetáculo, da perda nítida da fronteira entre a realidade e a fiç̧ão. Portanto, o teatro precisa levar a cena para o espaçotempo real, e não somente levar o real para a cena. $O$ uso de arquiteturas quaisquer como "locações teatrais" dialoga com esse movimento das artes cênicas contemporâneas de anexação do real.

A sala à italiana é o espaço ideal para a representação dramática, pois corresponde ao espaço de dimensões médias e estáticas, cujas possibilidades de distanciamento e aproximação da cena ficam restritas ao recurso da iluminação e do foco do jogo teatral, capaz de fixar o olhar do espectador em pontos específicos. A escolha de outro espaço, diferente da sala à italiana, possibilita a escolha de um ponto de vista, de um recorte específico da imagem. Ao escolher enquadramentos, o encenador ganha uma autonomia que não tinha no palco convencional, proporcionando ao espectador uma experiência compartilhada. Diante dessas constatações, torna-se inevitável a saída da sala tradicional, a não ser que o uso desse espaço também fosse reinventado.

Segundo Hans-Thies Lehmann, a proximidade com o público gera uma dinâmica centrípeta, confundindo as fronteiras entre ficção e realidade, pois a cena não se apresenta como conjunto de signos legíveis, mas como partilha de um mesmo momento. No espaço de dimensões grandes, experimenta-se um efeito centrífugo: o público é convidado a uma atitude de contemplação de um espaço físico e o encenador não tem domínio sobre seu olhar. A investigação 
de alguns procedimentos cinematográficos seria limitada caso optássemos por um local de dimensões medianas.

O espaço imenso e o espaço íntimo tendem a se tornar perigosos para o drama. Tanto num caso quanto no outro a estrutura do espelhamento deixa de existir ou fica em perigo, na medida em que o quadro cênico funciona como um espelho que permite ao mundo homogêneo do observador reconhecer-se no mundo fechado do drama. (LEHMANN, 2007, p.265)

\section{Escolha da locação}

"Mas se digo que Brasília é a imagem da minha insônia vêem nisso uma acusação. Mas a minha insônia não é bonita nem feia, minha insônia sou eu, é vivida, é o meu espanto."

Clarice Lispector

Para encontrar a arquitetura mais instigante para uma encenação teatral "cinematográfica", o Coletivo experimentou os seguintes espaços, todos no Campus da Universidade de São Paulo: o fosso da Faculdade de Arquitetura e Urbanismo, o Biênio da Politécnica, o Velódromo do Centro Poliesportivo, o "Buraco" da FAU e o Bosque da Física. Alguns deles foram sugeridos pela autora, outros pelos jogadores. Cada espaço deu sua lição e revelou seus jogos. Por um lado, o Coletivo buscava apropriar-se do lugar; como resposta, o lugar apontava caminhos para que fossem percorridos. A coleção intitulada "Jogos do Olhar" são os segredos descobertos no contato íntimo com a materialidade dessas arquiteturas.

A exploração dessas arquiteturas foi registrada pelo olhar atento de Renata Velguim, cujas fotografias retratam com precisão a vivência do Coletivo - Jogos do Olhar nesses espaços (fotografias no Anexo II). Suas fotografias imobilizaram imagens efêmeras desde seu primeiro esboço (imagem estática) até sua concretização final (imagem em movimento), confirmando nossa opção por uma dramaturgia de imagens. Segundo Renata, esse processo foi feito para ser fotografado, é como se cada encontro do Coletivo com um espaço fosse um ensaio fotográfico, pois os jogos sempre resultavam em imagens vistas de certo ponto. Voltaremos a essa questão mais adiante. 


\section{a) O Velódromo}

O Velódromo representava o desejo de lidar com um espaço de dimensões imensas, o que possibilitaria a criação de variações amplas de distância entre a cena e o público (muito distantes ou muito próximas). Lá, a sensação era de constante circularidade, repetição e continuidade. O lugar colocava a todos num estado de contemplação, talvez porque as longas distâncias cansassem as pernas. Sua grandiosidade física causava estranha liberdade misturada com dura percepção de limitações, pois, ainda que grandioso, era limitado. Apesar de se tratar de uma arena oval, deserta, no meio do Campus da USP, a cidade de São Paulo a emoldurava e vigiava.

"Podemos ser observados por tantos e por ninguém". Esta frase foi escrita por uma jogadora durante a exploração do Velódromo. É interessante perceber que ela observava o espaço como se o filmasse, atenta ao que ele sussurrava aos seus ouvidos (Jogo do Enquadramento, incluído na Coleção de Jogos do Olhar). Talvez pela dimensão do Velódromo, tenho a impressão de que os jogos se encaixavam perfeitamente nesse espaço, ali eles eram visíveis. Ao explorar os enquadramentos, os jogadores conseguiam produzir imagens que traduziam muito bem a operação do jogo proposto. Exemplo disso é o trecho a seguir, extraído de uma discussão de final de encontro: "O espaço é um emaranhado de informações sem seleção. O corpo é uma lupa para o espaço."

Lá, aconteceu um fato curioso, o Caderno de Encenação ${ }^{9}$ desapareceu. Provavelmente, foi esquecido no meio da quadra que ficava no centro do Velódromo. O fato é, na manhã seguinte, ele não estava lá, alguém o encontrou, o levou até uma quadra coberta e depois de alguns dias o entregou no achados e perdidos. Quando peguei o caderno de volta, ele estava com as marcas da noite no sereno, com a capa empenada. A transformação da materialidade do objeto parecia um sinal de que a ali deveria ser a "locação" da encenação. O Velódromo era a minha "menina dos olhos". Desde que comecei a pensar nesse projeto, imaginava os jogos acontecendo nesse espaço.

Para exemplificar a produtividade dos jogos ocorridos no Velódromo, transcrevo do Caderno de Encenação os títulos atribuídos às imagens criadas

${ }^{9}$ Caderno de registro das escolhas da encenação. Ao longo de todo o processo, produzi dois cadernos A4, sem pauta, em formato de bloco, utilizado na horizontal. 
em um dos enquadramentos explorados. As fotos desse jogo podem ser observadas no Anexo II. Foto 1: "ladeira", "enxurrada", "rolo compressor", "tsunami", "rio branco é o mar". Foto 2: "terceira margem do rio", "Beatles atravessando a rua", "HQ3D". Foto 3: "linha da evolução", "área de largada". Anotava todos os títulos sugeridos para cada imagem formulada, como forma de demonstrar a subjetividade própria da leitura.

O Velódromo ficou entre as duas locações mais votadas para a realização de nosso experimento. A sensação provocada por ele era grandiosa e as imagens criadas lá remetiam a antigas questões da humanidade, como se a imensidão do espaço provocasse uma volta à esfera da intimidade. Nesse espaço, o ruído da marginal do Rio Pinheiros era permanente e as interferências climáticas, determinantes. Pela exposição ao tempo e a falta de cuidados, o Velódromo nos pareceu demasiadamente sujeito às intempéries. Por esse motivo, o espaço não foi escolhido como locação de nosso experimento cênico.

\section{b) O fosso da Faculdade de Arquitetura e Urbanismo}

A Faculdade de Arquitetura mostrou-se para o Coletivo como uma complexa combinação de planos e volumes que possibilitaria a criação de cenas em recortes espaciais muito interessantes. Depois de observar a regularidade da convencional sala de ensaios (branca e quadrada), experimentar o prédio da FAU foi um exercício engenhoso para os jogadores. Vista do fosso, a faculdade apresenta-se como uma suntuosa combinação de cubos vazados e sobrepostos de forma assimétrica. Apenas o teto uniformiza o edifício, cujos andares são conectados por rampas que cruzam majestosamente o ambiente. As rampas de Vilanova Artigas rompem com suas diagonais entre plataformas, o jogo das coordenadas retas que se sobrepõem sobre nossas cabeças. A beleza dessa arquitetura é bastante apreciada pelos estudantes de arquitetura que são constantemente convidados a fotografar $e$ desenhar suas luzes e sombras. Até mesmo Elis Regina encantou-se com o espaço, filmando um videoclipe nesse local, talvez um dos poucos capazes de comportar a amplidão de sua voz. Toda beleza desse exercício formal inventado por Artigas abriga muitas atividades cotidianamente. Além dos cursos de Arquitetura e Urbanismo e Design Gráfico, inúmeras exposições e 46 
instalações disputam seus espaços vazios. A concorrência com outras intervenções artísticas e a interdição de produção de som na FAU impossibilitaram a realização de nosso experimento cênico nesse local.

\section{c) O Biênio da Politécnica}

O espaço arquitetônico do Biênio da Poli, chamado carinhosamente pelos alunos de "cirquinho" era um dos edifícios de formato mais interessante para o grupo: um disco voador, um cogumelo gigante, um sanduíche?

( protocolo de Adriane Escher)

“O espaço parece um infinito. Poderíamos dar voltas e voltas que sempre seria possível encontrar um espaço novo - partindo do centro ou das extremidades. O mais bacana é que num momento você perde a parede para o infinito. Ela não termina, mas você não consegue enxergar além. Esférica. Um horizonte numa parede vertical. Repartições e muito vidro. Brincadeiras com reflexos e sombras, além da profundidade. Parece que ao andar se abrirá uma passagem, uma porta secreta para outro mundo: afunilado, comprido, truncado, desproporcional, pequeno... Um espaço criado por Lewis Carroll para Alice. Siga o coelho branco!"

Cada espaço apresenta interrogações diferentes, portanto cabe ao encenador ler as demandas de cada um deles e propor modos de olhá-lo. $\mathrm{O}$ Biênio era uma arquitetura interessante de se ver de longe, pois só assim tinhase consciência da sua estrutura rítmica e repetitiva. Por isso, a proposição de compor fotografias foi realizada a partir de duas regras: o público olhando de fora do edifício e o público olhando de dentro dele.

\section{( protocolo de Adriane Escher)}

"Distância. Esticar o olhar para ver além do primeiro plano. Um tubo. Uma TV. Um jardim gigante e mais adiante uma visão refletida. O espaço que vem de fora e fica ali dentro, quase como a imagem refletida nos olhos de quem vê. Onde estão as referências? A imagem a minha frente reflete uma realidade que está atrás de mim, ou será abaixo? Onde será? Cadê os sentidos? O olhar é sempre uma encruzilhada, deve-se escolher o caminho por onde se quer percorrer a menina dos olhos. Ou ser o próprio caminho, mais um ponto, e compor a paisagem, ou indicar algum traço. Engraçado, hoje me senti parte do espaço, deitada na linha interrompida da grama descobri o que ela sente tendo o céu como teto. Uma liberdade justa."

O Biênio da Poli não foi escolhido como locação para o experimento cênico, pois o espaço não estaria disponível para ensaios, uma vez dentro do cogumelo gigante habitam salas de aula e de estudo. 


\section{d) O "buraco" da FAU}

(protocolo de Jhony)

"Relógio, alface, aranha, caixa, quadrado, mata atlântica, ponteiros, círculo, quatro apoios, roda, metrô, consultório médico, diferenças, coceira, goteira, dança indígena, baú... Depois veio a criação da cena de três fotos, onde fizemos um trabalho com dois grupos. $1^{a}$. CENA: Vi uma aranha indo em direção à luz, uma não, várias aranhas se rastejando até a luz, dando impressão de profundidade, pois a cena revelava um cenário de fundo. $2^{\mathrm{a}}$. CENA: cofre ou oráculo? Talvez um oráculo para acessar o cofre? O Tempo ficou muito claro, a marcação do tempo, as trocas de posições. Foi ótimo esse contato com o corpo no espaço."

Um espaço de dimensões pequenas, que sintetiza dois outros: 0 Velódromo em miniatura e a circularidade do Biênio. Esse foi o primeiro espaço sugerido pelo grupo para experimentação. Foi batizado pelos alunos pelo nome "buraco" da FAU. Aos nossos olhos, era um micro teatro de arena e na realidade, um antigo buraco destinado a um sistema de ventilação (ou refrigeração) não concluído. Esse lugar foi sintetizador de algumas questões importantes: primeiro, revelou a importância para a pesquisa de um espaço de dimensões maiores; depois, apontou pistas para a relação entre o espaço e o corpo, como mostra o protocolo abaixo.

$$
\text { (protocolo de João) }
$$

"Quando discutimos sobre a performance do $1^{\circ}$ grupo, um ponto levantado era que a idéia de se 'mostrar' havia se perdido, porque o corpo/ator ficou em primeiro plano, o que é de certa forma inevitável quando num espaço 'imóvel', alguém se movimenta. Mas o espaço é sempre imóvel? 'Tudo flui', disse o filósofo Heráclito (c. 540-480 a.C.), 'Tudo está em fluxo e movimento constante, nada permanece. Por conseguinte, 'não entramos duas vezes no mesmo rio'. Quando entro no rio pela segunda vez, nem eu nem o rio somos os mesmos.' O movimento está sempre presente, mas a forma de representá-lo pode alterar a forma como vemos o espaço. Acredito que o movimento dos atores estava em sintonia com o que foi percebido. Mas para que o ator deixasse de existir e se tornasse espaço, acredito que uma das soluções seria vesti-lo, camuflar-se nele, usando elementos dele como vegetação, materiais, cores, etc. Teríamos uma miragem, ilusão de óptica naquele espaço que superficialmente é imóvel. Acho que resumiria o meu protocolo dessa aula em uma palavra: miragem. Interagir com o espaço de forma a se tornar parte dele. Estaticamente ou em movimento."

A composição de imagens nesse espaço transformou arquitetura em espaço de ficção. Rapidamente, o pequeno espaço foi subvertido, provavelmente pelo seu caráter de inacabado. Como ele não tem uma 
utilização clara, óbvia, um lugar de uso indefinido torna-se facilmente um "cenário".

\section{e) Bosque da Física}

$$
\text { (protocolo de Adriane Escher) }
$$

"Tudo escuro. Cheiro de mato, um pouco doce e úmido. Barulhos de grilos e das folhas secas sendo pisadas. De longe uma pessoa parece que surge. Um espectro. Um vulto. Não se vê os pés ou cores mais escuras. Tudo é muito alto e misterioso. Uma folha pode ganhar vida, quase um sonho, um filme de terror. Com os bastões vi ritual, ligação com terra, bruxaria. A roda também me veio à idéia de culto, celebração. Nas propostas, o espaço ganha vida e as

pessoas viram espectros. Estranho, dá medo, confunde. De fundo, sons de tambores. A floresta sempre trás o desconhecido, o obscuro. Daí a cabeça faz mais com o espaço, cria imagens, medos, parece que tudo o que queremos ver, ou que imaginávamos vem à tona."

O Bosque da Física foi outro espaço sugerido pelos jogadores. Para nos apropriarmos dele e, supondo que realizaríamos ensaios e apresentações à noite, optamos por realizar dois ensaios no local: um no período da tarde e outro à noite. Embora o ensaio diurno tenha sido interessante, o ensaio da noite foi assustador. O Bosque é muito escuro, tem terreno irregular e é freqüentado, durante a noite, por pessoas com atividades suspeitas. As impressões do ensaio noturno eliminaram as possibilidades de realizarmos a encenação no Bosque da Física. Vários empecilhos foram levantados: ambiente pouco iluminado, sem fontes de energia, perigoso para atores e espectadores. Caso optássemos por apresentar no período diurno, ensaios e apresentações estariam sujeitos a cancelamento, devido a chuvas.

$$
\text { (protocolo postado no blog < jogosdoolhar.zip.net > por Renata Velguim) }
$$

"Oi pessoal, estou tentando inserir uma imagem sobre o Goeldi, um artista plástico do modernismo brasileiro que tem como temática o isolamento humano, acho que tem bastante a ver com o que sentimos no Bosque da Física à noite."

(protocolo de João)

"Adentrar no bosque escuro da USP é invadir um universo desconhecido. Pra mim ficou clara a sensação do vídeo game, aonde as imagens vão se formando à medida que você vai avançando no jogo. O próximo passo é sempre um susto, uma surpresa que pode, ou não, ser agradável aos sentidos." 


\section{f) Centro Tecnológico de Hidráulica}

"Aqui é o lugar onde o espaço mais se parece com o tempo".

Clarice Lispector

Desde a primeira vez que entramos na Hidráulica, ficamos impressionados: um espaço difícil de ser descrito, um galpão muito grande com vidraças compridas e um tipo de cobertura que permitia a entrada da luz. Os modelos físicos reduzidos estavam dispostos de modo aleatório, apesar de aparentemente organizados. O conjunto de máquinas, quase monocolores, de tão monumentais ocultavam a grossa camada de poeira e ferrugem que encobria cada superfície férrea. Uma impressão estranha tomava conta de mim: uma sensação de nunca ter estado em um local similar, mas ao mesmo tempo, de estar diante de um lugar secreto onde máquinas tinham sido guardadas por uma espécie de colecionador. Uma impressão de testemunho histórico, como se diante de mim se materializasse um museu dos anseios humanos pelo desenvolvimento industrial. $O$ retrato futurista de um passado não muito distante. Da mesma maneira como vemos hoje o lixo eletrônico, aquelas máquinas eram um lixo mais pesado, caro, impossível de se recompor a natureza. $\mathrm{Na}$ Hidráulica, o ar estava parado, o tempo era lento, a sensação de permanência criava musgos ao lado de uma cabine cheia de computadores interligados em rede, encarregados de informar jornais, televisões e órgãos do governo sobre as previsões de chuva na cidade de São Paulo. O ruído dos computadores anunciava o que estava por vir: depois de termos finalizado o trabalho na Hidráulica, todas as máquinas foram retiradas e enviadas para algum cemitério da indústria, um ferro velho da História.

$$
\text { (protocolo Adriane Escher) }
$$

"O cheiro de ferrugem e o ar parado. Máquinas adormecidas, um passado quieto, verde das firmas que conheci quando era pequena. Sempre imagino carpas nos tanques com água, carpas escuras e de olhos fechados. Sinto-me pequenina, andar se torna um ato grande, assim

como respirar. A luz é amarela, branca, não sei, cansa, é como se eu ficasse um pouco máquina lá dentro, meio verde. É difícil manter a atenção, são tantas informações e buracos...

Frio, graxa, portões gigantes."

O Centro Tecnológico da Hidráulica atendia às necessidades de um espaço de médio ou de grande porte, possibilitando inúmeros enquadramentos e pontos de vista inesperados para o público. As plataformas e passarelas 
dividiam a arquitetura cúbica do galpão em muitos ambientes. E os "modelos físicos reduzidos" convidavam os olhares a exercícios de ressignificação. Os diferentes níveis do espaço possibilitavam cenas em locais variados, como se fossem diferentes locações. Por concentrar em suas máquinas a história da ciência, do desenvolvimento tecnológico, do avanço e controle do Homem sobre a Natureza, a Hidráulica foi escolhida como locação dessa pesquisa teatro-cinematográfica. De Centro de Ensaio de Máquinas passou a palco de experimentações cênicas.

Curiosamente, mais tarde descobrimos que um Centro de Estudos de Tratamentos de Água em Londres tornou-se espaço cultural (Wapping Project), conhecido pelas apresentações de dança e teatro, exibições de vídeos, exposições de fotografia e pelo ótimo restaurante ali instalado. Recentemente, no entanto, tivemos notícias de que todos aqueles modelos físicos reduzidos alojados no Centro Tecnológico de Hidráulica foram removidos de lá. O imenso galpão terá agora outras finalidades. Nossa locação foi desmontada, à semelhança dos enormes cenários dos filmes realizados nos estúdios da $\mathrm{UFA}^{10}$, descritos por Siegfried Kracauer no texto "O mundo de Calicó"11: A Cidade-Cinema da UFA".

Vale a pena ressaltar, a partir do protocolo abaixo, um aspecto pedagógico recorrente: a constatação da influência das análises fílmicas nos jogos de apropriação do espaço. Por exemplo, a valorização da profundidade de campo é um recurso estilístico recorrente nos filmes analisados. A conseqüência disso na composição das cenas teatrais foi a exploração da profundidade do "campo" ou do "enquadramento" teatral recortado nos espaços arquitetônicos visitados.

(protocolo de Arnaldo)

“Antes de chegar à Hidráulica, antes de entrar pela primeira vez, o nome 'Hidráulica' pouco nos diz, pois não temos referência do que vem a ser ou do que se faz ali. Imaginamos uma instalação industrial ou uma fábrica. Isso é muito interessante, pois mexe com a expectativa de quem vai entrar no lugar, sem saber o que esperar ou sem uma idéia consistente do que vai encontrar. No galpão o olhar se dispersa, são muitos patamares, muitas

10 Fundada em 1917, a Universum-Film AG (UFA) foi a maior companhia da indústria cinematográfica alemã até 1945, com grandes complexos de estúdio em Berlin-Tempelhof e Berlin-Neuebabelsberg. Foi adquirida em 1927 pelo Hugenbergrup Group, nacionalizada em 1936-1937 pelo Reich alemão e desmantelada pelos aliados em 1945.

${ }^{11}$ Calicó, tecido de algodão grosso originário da Índia muito utilizado na construção dos cenário de filmagem. 
máquinas, algumas "piscinas de água suja", uma cabine fantasma, uma tubulação "intestinal", dois corredores com janelas que podem servir a muitas cenas... Há barulho de ar condicionado que é esquecido durante o ensaio. Fizemos algumas cenas paradas (acho que podiam ser chamadas de Quadros) que nos dão a idéia da imensidão do lugar e das possibilidades de posicionamentos do espectador/câmera e da ação que encenamos. Trabalhamos (acho que é uma tendência dos jogos do olhar) as relações de profundidade de campo ou proximidade do espectador. Uma das cenas utilizou quase todo o espaço através do uso dos patamares e mostrou tanto o espaço perto como o mais alto e longe do olhar do espectador. Alguns quadros também evidenciaram o quanto o espaço é rico (algumas pessoas o consideram caótico) em detalhes e suas infinitas possibilidades de combinações corpo-máquina-olhar. Finalmente trabalhamos não apenas os quadros como também cenas com ação, ou começo, meio e fim. Não basta apenas se apropriar do espaço, mas criar movimento encadeado. Mais desafiador.

PS: no aquecimento usamos o jogo da máquina: cada um de nós era uma engrenagem. Começou a inspiração dessa locação fascinante."

\section{Conceito de representação inspirado na geometria}

"O teatro é, na verdade, essa prática que calcula o lugar olhado das coisas" Roland Barthes

Ao pensar a cena teatral contemporânea, a bibliografia com a qual se dialoga é o livro "Teatro pós-dramático", do alemão Hans-Thies Lehmann" ${ }^{12}$ O conceito de teatro pós-dramático, criado pelo autor, engloba uma gama de espetáculos recentes, elaborados a partir das tentativas de rompimento e salvação, legíveis ao longo da crise do drama. Lehmann traça um panorama de contornos imprecisos da produção teatral contemporânea, o que não invalida a atualidade do estudo e a pertinência do diálogo com o instrumental organizado pelo autor. De maneira surpreendente ele cataloga, classifica as teatralidades contemporâneas da "pré-história do pós-dramático" (Alfred Jarry, Antonin Artaud, Stanislaw Witkievicz, Gertrude Stein, para citar alguns) aos pósdramáticos radicais: Tadeusz Kantor, Michael Grüber e Robert Wilson. Situa Maurice Maeterlinck, "cujo esquema não é mais a ação, mas a situação" (FERNANDES, 2006, p. 10) no rompimento com a dramaturgia aristotélica, e o teatro pós-dramático como um teatro pós-brechtiano. Mesmo que o teatro de Brecht incorpore o processo de representação na cena e demande uma atitude

\footnotetext{
${ }^{12}$ Nesse estudo, utilizou-se inicialmente a tradução francesa de Philippe-Henri Ledru (citada na bibliografia) do original alemão "Postdramatisches theater", publicado pela Verlag em Francfortsur-le-Main, 1999. E, posteriormente, a tradução para o português de Pedro Süssekind, publicada somente em 2007 .
} 
ativa do espectador, seu teatro ainda se fundamenta na fábula, razão pela qual Lehmann exclui Brecht do amplo recorte pós-dramático.

Curioso que, seguindo o trilho dos nomes citados por ele, pode-se notar uma progressão na busca por um teatro renovado, ressignificado a partir da experiência da modernidade. Maeterlinck, em suas teses, renunciava ao conjunto tensão/drama/ação/imitação e pregava (antes mesmo de Gordon Craig e seu teatro da supermarionete) um teatro de andróides. Artaud apresenta-se como o escritor da utopia para um teatro ulterior - contra a primazia do texto e a favor da autonomia do espetáculo. Gertrude Stein escreve seus textos como se construísse quadros, imagens, paisagens (landscape plays). Assim como Bob Wilson "escreve" sua encenação com imagens, Kantor faz falar objetos, únicas testemunhas vivas dos horrores da guerra. Passando por Brecht, no entanto, Lehmann parece desconsiderar suas peças didáticas e, sobretudo, seus últimos fragmentos nos quais escreve sobre o egoísta Fatzer, peça considerada "incenável". Fatzer é um "comentário" (que segundo Brecht, só servia para o próprio autor), é um texto ainda hoje pouco encenado, que busca outras sínteses possíveis apenas a partir de uma visão de mundo que está por vir.

Apesar de enxergar algumas restrições ao conceito de pós-dramático preconizado por Lehmann (como no exemplo citado acima), considero sua obra provocadora para as reflexões tecidas nessa pesquisa. A riqueza do panorama esboçado pelo autor está na proposição de parâmetros para a leitura da cena teatral contemporânea, a partir de convenções descoladas do drama. Afora algumas divergências, os encenadores citados acima avançam em uma direção não específica, mas fugindo do ponto comum anterior: o teatro "dramático", de "imitação" e “ilusão".

Dentro do contexto desse teatro pós-dramático, considerando-se as questões apresentadas neste estudo (um teatro fora do edifício teatral ou que subverte seu uso) buscamos uma definição de representação que resolvesse problemas identificados na prática aqui analisada.

A representação não se define diretamente pela imitação: se abandonarmos noções de 'real', de 'verossímil', de 'cópia', haverá sempre 'representação', enquanto alguém (autor, leitor espectador) dirigir seu olhar para um horizonte e nele recortar a base de um 
triângulo de que seu olho (ou sua mente) será vértice. [...] O palco, o quadro, o plano, o teatro, a pintura, a literatura, isto é, todas as 'artes' exceto a música e que se poderia chamar: artes dióptricas. (BARTHES, 1990, p. 85-86).

Barthes utiliza a geometria para explicar a representação. A cena é considerada um objeto estético circunscrito num determinado espaço e tempo e observado pelos olhos (ou pelo esprit, em francês: mente ou espírito) de alguém, os espectadores ou a câmera. De certo modo, esse conceito abarca as duas linguagens comparadas nesse estudo: o teatro e o ciema. Barthes enxerga a cena por uma ótica formal, não temática. Afasta a representação da idéia de mímese e a aproxima da geometria, daquilo que é mensurado pelo olhar. Mais adiante, no mesmo texto afirma que "No cinema, no teatro, na literatura tradicional, as coisas são sempre vistas de algum lugar, é o fundamento geométrico da representação" (Ibidem, p. 91). Desde as considerações sobre a cena elaboradas por Diderot, reflete-se sobre a função pictórica do que é posto em cena, promovendo uma coincidência entre o recorte visual e o recorte das idéias. Tanto Barthes quanto Diderot, seja utilizando a geometria, seja a pintura, referem-se ao teatro realizado na sala à italiana. Entretanto, os problemas apresentados na presente pesquisa dizem respeito às cenas construídas em toda e qualquer arquitetura, onde a demarcação e a dissolução do espaço cênico dependem das escolas da encenação.

Marilena Chauí também refletiu a respeito do ponto de vista, que corresponde em grego à skópos, "idéias e opiniões dependem de onde vemos o real, também nos ensina que se trata da visão feita nas alturas, que abarca até os confins do horizonte e o todo do mundo circundante" (CHAUÍ, 1988, p.37). Sua ciência chama-se optikê (em grego) e perspectiva (em latim), a qual designa a escolha do ponto de vista. A perspectiva pode ser considerada a representação geométrica da visão, ressaltando o ponto em que se situa o olho do observador, aquele que vê para frente e em profundidade.

Dada essa primazia do visual, a diferença vem da técnica: o que o tableau teatral sugere pela configuração visível da cena, o cinema pode oferecer, com maior controle, mediante enquadramentos variados. Nesses, é a posição da câmera que materializa a idéia do 
vértice do cone da representação - aquele ponto de observação para o qual a cena se volta. (XAVIER, 2003, p. 66)

Através dessa teoria geométrica da representação, encontramos no modo de proceder cinematográfico uma tradução para a criação de cenas visíveis a partir da composição de imagens. Simplesmente por se tratar de uma câmera que recorta um espaço específico, criando sentidos, estabelecendo relações e dispondo elementos entre si. Sobretudo no que se refere ao teatro fora da sala à italiana, onde o lugar do público não está definido pela arquitetura, a aplicação de procedimentos cinematográficos pode ser considerada uma saída para a composição da cena teatral.

Fora da sala tradicionalmente teatral, considera-se o espaço segundo dois aspectos: o espaço do jogo dos atores e o espaço do espectador. Ao utilizar qualquer espaço arquitetônico como espaço cênico, a definição dos pontos de vista da cena é primordial na construção da encenação. Apesar de, nesse estudo, o assunto ser tratado dessa forma, não é unânime essa opinião entre os encenadores que se apropriam de espaços não convencionais para se fazer teatro. Muitas vezes, a posição e o percurso do público são definidos junto com o roteiro final, nem sempre é o ponto de partida.

$$
\text { (protocolo de Felipe Pitta) }
$$

"A cena não é apenas de quem joga, mas também de quem a observa."

\section{Procedimentos cinematográficos para novas arquiteturas teatrais}

Apresentaremos a seguir alguns procedimentos cinematográficos para a composição de cenas teatrais fora do Teatro ou que subvertam sua utilização convencional. Nessas condições, diante do impasse vivenciado pela cena desprovida de lugar para o observador, apresentamos dois procedimentos cinematográficos: a definição da posição da câmera e a escolha dos enquadramentos. A posição da câmera pode ser entendida como posição do público e o enquadramento como o recorte no âmbito do qual acontecerá a cena teatral. A escolha dos enquadramentos reflete a escolha dos pontos de vista, estando diretamente relacionada à posição do público. Isso interfere na leitura que o público terá da cena, portanto é importante descobrir maneiras de direcionar o olhar do espectador para as escolhas da encenação. Lehmann 
associa essa escolha, no teatro de Bob Wilson, aos recursos teatrais de molduragem, fazendo com que "cada detalhe seja objeto da função estética do isolamento e ganhe um valor de exposição próprio" (LEHMANN, 2007, p.273).

O espaço não teatral amplia a possibilidade de movimentação do olhar do espectador, que, neste estudo, será sempre associado ao olhar da câmera. Aqui optamos por partir da definição do ponto de vista do público. Já que o público não tem lugar pré-estabelecido, o primeiro passo é defini-lo. Dessa forma, os atores têm clareza de onde vêm os olhares que os observam.

Em um primeiro momento da escolha dos enquadramentos, o espaço apresenta-se ainda sem atores. Ao definirmos a posição do público, voltamos ao significado da palavra théatron, do grego, lugar de onde se vê. Diz-se que o cinema é um olhar sem corpo. Nessa proposta devolvemos o corpo para esse olhar - o corpo do público.

Se a câmera é considerada o olhar do espectador, as posições e movimentações da câmera nos filmes precisam ser observadas. Podem-se destacar dois ângulos de enquadramento, além da posição frontal: o plongée e o contra-plongée. Emprestada do francês, essa palavra significa "mergulhar", um movimento de cima para baixo, tal qual o ângulo da câmera ao observar a cena. O contrário disso, o contra-plongée, a câmera observa de baixo para cima. Por exemplo, em uma das cenas finais de "Bandido da Luz Vermelha", de Rogério Sganzerla, um político corrupto é mostrado discursando pelas ruas, filmado para um programa de TV. Numa primeira tomada, o político é visto em contra-plongée (de baixo para cima); esse efeito aumenta sua imagem e conseqüentemente, seu poder. Posteriormente, com a entrada da locução de rádio que perpassa o filme inteiro, questionando criticamente os acontecimentos, a câmera muda radicalmente o ângulo para plongée (passa a olhá-lo de cima para baixo). Desse modo, vê-se a imagem do político ser diminuída, paralelamente às críticas destiladas pelo casal de locutores do programa radiofônico. Portanto, a transposição dos ângulos de enquadramento para a criação da cena teatral acontece definindo-se posições para o público em plataformas diferentes das cenas.

Outra maneira de abordar o tema: um acontecimento no meio da rua, observado por um transeunte que a atravessa, é uma cena; observada do terceiro andar de um prédio, é outra; observada por alguém que passa em um 56 
carro em movimento, é ainda outra. Dessa forma, pensamos na posição do público em relação à cena.

Entendemos que a definição da posição do público e a demarcação precisa do enquadramento no espaço não teatral colaboram para a exclusão do que "não é cena" do foco de atenção do espectador. De outro modo, o encenador também poderá optar por deixar a cena dissolver-se na arquitetura, seja para convidar o público a observar a locação na íntegra, ou o entorno dela, seja para propor o confronto entre cena e espaço arquitetônico como um todo. Sabemos que para haver realmente um enquadramento seria necessário a presença da câmera, pois é da sua natureza enquadrar tudo o que vê. Como já discutido aqui, a estrutura do palco à italiana corresponde a certo tipo de enquadramento, uma vez que se trata de uma edificação que exclui do olhar do público tudo o que não é cena. No palco tradicional, é possível convidar o público a olhar partes e não o todo, com o auxílio da iluminação que estabelece recortes precisos. Entretanto, não seria possível, nessa arquitetura, reproduzir a escala de planos cinematográficos, pois essa proposição demanda a aproximação ou o distanciamento da câmera, ou seja, do público. Os espectadores teriam necessariamente que aproximar-se ou distanciar-se da cena.

$\mathrm{Na}$ fase de apropriação do espaço por parte dos jogadores, recorremos ao jogo do enquadramento (descrito na Coleção - Jogos do Olhar) desenvolvido a partir de proposta de observação do espaço criada pelo professor Jean-Pierre Ryngaert. Propostas similares a essa são utilizadas em aulas de desenho de observação, pois a máscara de papel recorta o campo de visão (à semelhança de uma câmera), ajudando o desenhista a selecionar as imagens que serão reproduzidas. Em oficinas de cinema e vídeo esse procedimento também é adotado, geralmente com um papel cartão grande e preto, do qual se recorta um pequeno retângulo que simula uma tela de cinema. Durante todo o processo criativo, na exploração dos espaços visitados utilizamos o jogo do enquadramento. Esse simples instrumento de trabalho (máscara de papel) colaborou para educar o olhar no sentido de fazer revelar parcelas de espaço que seriam ocupadas pelos jogadores. No momento em que a máscara era retirada, os jogadores buscavam elementos presentes no espaço para servirem de balizas para sua delimitação. 
(protocolo de Daniel Cordova)

"Depois da experiência com o Coletivo - Jogos do Olhar comecei a olhar o espaço em recortes, além do todo."

Após a escolha dos enquadramentos correspondentes aos pontos de vista do público, os jogadores buscavam ocupar o espaço com seus corpos estáticos, compondo fotografias (Jogo descrito na Coleção de Jogos do Olhar). A partir da perspectiva do público, um jogador coloca-se no espaço, buscando preencher e apontar os limites do recorte espacial. Outros jogadores podem complementar a fotografia, compondo-a coletivamente. Em seguida, os jogadores que estão de fora da fotografia dão nomes para ela, revelando temáticas apontadas pela relação do grupo com o espaço.

\footnotetext{
O teatro de Robert Wilson é exemplar do 'efeito quadro'. Não é sem razão que freqüentemente se tem comparado esse teatro com a tradição do tableau vivant. Sabe-se que no século XVIII as damas e senhores da sociedade tinham o hábito de se divertir imitando pinturas, imobilizando-se com as poses e vestimentas correspondentes [...]. O que é correto na comparação é que no teatro da lentidão a percepção inevitavelmente se orienta para o foco com que se percebe um quadro. $O$ que é falso é que o retardamento cerimonial não visa o reconhecimento de um quadro famoso, mas a presença teatral viva dos gestos humanos e das formas em movimento. (LEHMANN, 2007, p.272-273)
}

Variações dessa proposta podem acontecer no que se refere à distância da câmera da cena, seguindo a escala de planos descrita no capítulo anterior. Assim definimos uma panorâmica, alguns planos gerais, muitos planos de conjunto e alguns planos médios. Desse modo, contrariamos a afirmação de André Malraux de que "o ator de teatro é uma cabeça pequena numa grande sala; o ator de cinema, uma grande cabeça, numa sala pequena" (MALRAUX, 1959, p.91). Durante o processo criativo, chegamos a uma proposta de close na cena teatral muito interessante. Um jogador segurava uma espécie de manilha, parte de um tubo de água grande e redondo, na altura de seu rosto, e convidava o público a acompanhá-lo dizendo "pílula". Na encenação, a mesma cena foi substituída pelo mesmo jogador propondo um travelling de ré ao 
público, pois andava de costas em um longo corredor, oferecendo balas que chamava de "pílulas".

As movimentações da câmera também foram destacadas, como descritas no capítulo anterior: panorâmica (um movimento de câmera, num tripé ou na mão da pessoa que filma, sem se deslocar) e travellings (deslocamentos da câmera em diversas direções - frente, trás e lados) ${ }^{13}$. No primeiro caso, tratavase de colocar o público em pontos que pudesse observar o espaço como um todo. No resultado final, uma panorâmica foi definida no final do percurso, único momento em que todas as luzes do galpão eram acesas, revelando-o em sua integridade. O segundo caso será tratado no capítulo seguinte.

Um procedimento cinematográfico foi objeto de intensas reflexões no Coletivo de jogadores, o superenquadramento, ou seja, quando a câmera enquadra um recorte espacial que já sugere um enquadramento. De fato, perceber que determinados "obstáculos" arquitetônicos cumprem o papel da câmera, tais como janelas, portas ou a combinação de vigas e pilares causando a impressão de moldura, foi determinante na idealização desse projeto. Pois, se aproveitarmos os enquadramentos já propostos pela arquitetura, acentuamos explicitamente a escolha do recorte espacial. Por outro lado, afirmar a possibilidade de tradução do superenquadramento para o teatro me parece fora de propósito, pois mesmo quando se observa um enquadramento dentro de outro, o olhar tende a desconsiderar 0 enquadramento maior, focando o menor. Isso poderia acarretar uma sensação de aproximação da cena dentro da escala de planos. Por exemplo, um enquadramento maior definiria um plano geral e um subrecorte dentro desse enquadramento corresponderia a um plano médio ou próximo. Por isso discordo da possibilidade de superenquadramento no teatro fora do edifício teatral. O superenquadramento só pode ser percebido através da câmera, pois ela exclui definitivamente o que está fora do enquadramento, imprimindo o quadrado de sua mirada em tudo que vê. Talvez no espaço à italiana, em que a

\footnotetext{
${ }^{13}$ Há uma curiosidade a respeito da história do cinema que gostaria de ressaltar. Os irmãos Lumière ainda não haviam pensado na possibilidade de movimentar a câmera. Todos os seus registros eram feitos com a câmera parada, tal qual um espectador privilegiado sentado na platéia do teatro à italiana. No entanto, mandaram câmeras para algumas cidades européias com o intuito de apresentar essas cidades aos parisienses. Quando assistiram às imagens registradas em Veneza, na Itália, se deram conta da possibilidade de movimentar a câmera, pois nessa cidade ela tinha sido colocada em um barco para que o espectador tivesse a sensação de estar realmente passeando em Veneza.
} 
moldura do palco é mais nítida, pudéssemos causar a impressão de superenquadramento, sobretudo se essa moldura estivesse toda iluminada ou coberta por uma cortina marcante que estabelecesse claramente seus contornos. Por esse motivo, utilizamos esse procedimento como forma de revelar recortes propostos pela arquitetura, mas não buscamos transcodificá-lo para a linguagem teatral.

Nas experimentações práticas, chegamos a comparar o efeito da elaboração de um close e um superenquadramento a partir de um recorte arquitetônico. Após escolhermos diversos enquadramentos bem delimitados por alguma barreira ou limite arquitetônico, concluímos que os recortes próximos do público soavam como closes, e os distantes como superenquadramentos. Repito: embora reconheça que o conceito de superenquadramento tenha ajudado na configuração de "enquadramentos" teatrais, desconsidero a possibilidade de realização de superenquadramento no teatro, salvo o exemplo da sala à italiana apresentado acima.

Nas proposições de molduragem criadas por Bob Wilson, a definição de campos de luz geométricos e a precisão escultural dos gestos são responsáveis pela ilusão de moldura teatral. Na atual pesquisa, fora da sala tradicional, acrescentamos delimitações presentes na arquitetura escolhida à iluminação e à precisão dos corpos para se chegar à molduragem. Talvez Bob Wilson também tenha considerado as características da arquitetura em suas encenações a céu aberto.

Embora Ariane Mnouchkine afirme que sua encenação mais recente não tenha sofrido influências da linguagem cinematográfica ${ }^{14}$, podemos identificar a apropriação de certos procedimentos dessa linguagem na escritura de sua obra. O exemplo é rico inclusive por reafirmar nossa atitude diante da análise: observar o que é imanente à obra e não as intenções de seus autores. Mesmo sabendo que "Les Éphémères" coleciona situações efêmeras da vida e que tal

\footnotetext{
${ }^{14}$ Declaração prestada pela encenadora, na ocasião de sua visita ao Brasil, em um debate com o público no Itaú Cultural em 19/10/2007.

60
} 
qualidade é intrínseca ao teatro, o espectador atento não terá dificuldades em visualizar na estrutura dessa encenação, componentes cinematográficos. A pesquisadora francesa Béatrice Picon-Vallin também utiliza termos cinematográficos para analisar a criação do Soleil, como por exemplo, ao afirmar que "a ação se desenrola em planos-seqüência muito longos" (PICONVALLIN, 2007, p. 115). Além disso, a autora confirma, através dessa encenação, que o teatro assimilou e transpôs técnicas do cinema para sua concepção.

\section{“Les Éphémères”, criação do Théâtre du Soleil, encenada por Ariane Mnouchkine :}

A última produção do Théâtre du Soleil inova ao mostrar a cena para o espectador e dialoga com o cinema ao estruturar sua mise-en-scène em plataformas redondas e rolantes. Tais plataformas permitem que as cenas desfilem sob os olhares do público como carros alegóricos do carnaval. Os espectadores, posicionados em duas arquibancadas frontais, transformam o espaço cênico num corredor. Nos carrinhos que suportam as cenas, os cenários são meticulosamente dispostos à maneira naturalista. Por exemplo: numa cozinha com fogão que funciona, prepara-se e come-se uma massa. A intimidade desses fragmentos de mundo é cuidadosamente manipulada por atores agachados, movendo-se como gatos ágeis e precisos, que imprimem o ritmo exato à situação dramática representada.

Pode-se identificar certos procedimentos cinematográficos no desfile das cenas do Théâtre du Soleil e para isso é preciso observar a cena teatral para além do texto. Por exemplo, o tom naturalista da representação dos atores, aliado aos diálogos cotidianos presentes no texto, poderiam ser lidos como "cinematográficos". Entretanto, o dado cinematográfico está na quebra das "quatro paredes" desse naturalismo. A cena que gira diante do espectador tem sua tridimensionalidade explicitada, podendo ser observada de muitos pontos de vista. Ainda nesse aparato cênico, onde são acondicionadas todas as cenas, mais um procedimento pode ser extraído, pois além de girar, a cena desliza na passarela como se fosse um longo travelling lateral. Assim, ao mostrar personagens assistindo de maneira rudimentar à projeção de um filme, a companhia francesa apenas acolhe o material audiovisual no seu espaço 
teatral; em contrapartida, ao colocar cenas rotatórias deslizando como se fosse uma esteira rolante, fala do efêmero de forma cinematográfica. Na primeira passagem (em que os personagens assistem ao filme) anuncia que nesse mundo existe cena visível projetável. Ao colocar as cenas rotatórias, apropriase do "estilo" da outra linguagem, como se convidasse a platéia para brincar de ser câmera, circulando em torno da cena, sobre patins, numa extensa pista teatral.

\section{Coleção dos Jogos do Olhar - Espaço}

Anteriormente, no primeiro capítulo, apresentamos jogos para "ler" cinema; os jogos apresentados a seguir convidam o leitor a "fazer" teatro. A série de jogos descrita abaixo propõe a apropriação de espaços arquitetônicos como espaços cênicos. Eles correspondem a modalidades de trabalho experimentadas pelo Coletivo - Jogos do Olhar nos diversos espaços que percorreu, representando os pontos de partida para a escritura das cenas organizadas na encenação "ISAURA S/A +1 Experimento Hidráulico".

\section{O enquadramento de Ryngaert:}

Jogo recorrente na fase de apropriação do espaço, proposto por Jean-Pierre Ryngaert e descrito na dissertação "Pedagogia do Jogo Teatral: uma Poética do Efêmero. O Ensino do Teatro na Escola Pública" (SOARES, 2003). Tratase de utilizar máscaras de pape ${ }^{15}$, através das quais os jogadores observam o espaço recortado. Ao longo da trajetória, pede-se aos jogadores que anotem suas impressões sobre o que apreciaram, sem descreverem o que vêem.

\section{Percepção do espaço pela palavra: \\ Jogo coletado de "Encenação em Jogo" (MARTINS, 2003) ${ }^{16}$ que consiste em colher impressões dos jogadores "após uma abordagem física e sensorial do espaço". Há várias versões: as palavras, expressões ou frases produzidas}

\footnotetext{
${ }^{15}$ Medidas aproximadas: recorte um retângulo de $15 \mathrm{~cm} \times 12 \mathrm{~cm}$, com outro retângulo vazado de $7 \mathrm{~cm} \times 4 \mathrm{~cm}$, posicionado no centro do primeiro retângulo.

${ }^{16}$ A autora participou da experimentação prática do mestrado de Marcos Bulhões, cujo trabalho tem fortes influências sobre a pesquisa aqui apresentada. 
pelos jogadores podem ser escritas ou faladas. O texto ao qual se chega corresponde à tradução poética da percepção do espaço.

O registro poético abaixo foi realizado coletivamente após a experimentação do espaço da Faculdade de Arquitetura e Urbanismo na Cidade Universitária da USP. Depois de observar esse edifício projetado pelo arquiteto Vilanova Artigas, através das máscaras de papel descritas no "Jogo do enquadramento", o Coletivo produziu as seguintes impressões:

"Foto do calçadão. Praça. Intersecção. Flecha. Ponte. Fluxo. Hospital. Enquadramento. Árvore. Leveza. Peso. Alguém está só. Colméia. Meio e meio. Saudade da minha avó.

Caverna. Nascer do Sol. Brasília. Perspectiva. Perto. Detalhes. Passagem. Chuveiro. Desconforto. Poética. $Z$ das rampas. Encontro de arestas. Se melam se amam. Viagem. Cartão postal. Trabalho. Pipa com rabiola pequena. Outra foto. Parede de fuzilamento. O outro olhando outra coisa. Quadro negro. Alguém passeia sozinha. As mãos de alguém que procura. Jovem suicida. Degradê. Reforma do bar. A poça verde. Dia nublado. Três duplas. E se eu fosse o Artigas?"

\section{Composição de figuras geométricas:}

Jogo desenvolvido pela Cia. São Jorge de Variedades, sob coordenação de Georgete Fadel. O coordenador propõe que os jogadores formem figuras geométricas (maior círculo possível, menor círculo, linha paralela à parede tal, quadrado, triângulo, espiral) posicionando seus corpos, sem combinação verbal. É uma boa preparação para o treino de coros, colaborando para a percepção da composição espacial do grupo.

\section{Composição de imagens fixas - "fotografias":}

Jogo adaptado a partir de experiência com a professora Maria Lúcia Pupo, por sua vez baseada em Jean-Pierre Ryngaert, nas aulas de "Jogos Teatrais" no Departamento de Artes Cênicas da ECA/USP, que consiste em compor uma imagem estática, como uma fotografia, em um espaço pré-estabelecido. Aqui, propõe-se uma abordagem a partir do "jogo do enquadramento“. Com as máscaras, recorta-se o espaço com a ajuda da arquitetura, ou a partir de algum referencial presente nele, para que o enquadramento possa ser percebido mesmo a olhos nus, sem a ajuda da máscara. Define-se a partir de 
então o espaço cênico (enquadrado) e a posição do público (ponto de vista da câmera). O público, constituído pelos demais jogadores, pode esperar para receber a imagem de olhos fechados. Apesar de todos os conhecerem o recorte proposto, os observadores serão surpreendidos, pois não sabem em que pontos do espaço os jogadores aparecerão. Em seguida, os que estão de fora da imagem buscam títulos que sintetizem uma leitura da ocupação do recorte arquitetônico.

\section{Camuflar e apontar:}

Jogo elaborado a partir das visitas aos espaços e de conversas com o Coletivo. Ao escolher enquadramentos e pontos de vista, durante o jogo da composição de fotografias, os jogadores procuram camuflar-se no espaço, tornar-se espaço, confundir-se com ele, ou apontar o espaço, revelando seus limites, delimitando-o. Esse jogo contribui para que os jogadores considerem o espaço na composição da fotografia, ao invés de criá-la pensando em uma situação previamente concebida.

\section{Panorâmica teatral:}

Uma variação do jogo de composição de fotografias. Busca-se descobrir panorâmicas, isto é, locais escolhidos para o público apreciar o espaço como um todo. A atenção volta-se para dois pontos: manter o público parado e garantir que as pessoas movam a cabeça, deixando seus olhos passearem pela imagem contemplada, definindo livremente o percurso de seus olhares. Assim, como só há vistas panorâmicas em espaços de grande dimensão, para o público ter uma impressão de panorâmica, é preciso distância para olhar.

\section{Plongée e contra-plongée: \\ Escolher pontos de vista para as cenas: de cima para baixo (plongée) e de baixo para cima (contra-plongée). Os jogadores devem definir um local para acomodar o número estabelecido de espectadores mirando um enquadramento abaixo do piso onde se encontram. No caso da Hidráulica, aproveitamos as plataformas existentes no galpão. Se o local utilizado para o jogo não tiver essas características, o posicionamento dos atores no chão}


sendo observados por espectadores de pé, já causa a impressão de plongée. Para um contra-plongée basta inverter a regra: definir local para acomodar o público mirando espaço acima de suas cabeças, em outro piso, plataforma ou móvel, de modo que conduza o olhar do espectador para cima.

\section{(protocolo de Adriane Escher)}

"Acho que depois da experiência com o Coletivo - Jogos do Olhar mudou muita coisa. Afinal, foi um processo longo e no qual mergulhamos de cabeça - pelo menos é essa a impressão. Talvez eu só tenha a real noção de tudo daqui a alguns anos, analisando meus próximos passos. Sinto que a parte que mais me apropriei foi em relação ao espaço, e mesmo do treinamento corporal. Ah! A coisa que mais faz sentido agora é notar o quanto o processo é visível em cena, o quanto cada etapa tem seu valor e é realmente necessária, e o quanto partilhar dele, entendê-lo e questioná-lo é importante para a compreensão da experiência. $O$ processo sendo um procedimento aberto, transparente, provocativo."

\section{O Corpo como território do jogo}

Assim como não se deve separar espaço de tempo, nessa investigação não separamos o corpo do espaço. Ainda que em um primeiro momento tenhamos observado o espaço de fora dele, como espectadores, ele só é recortado, delimitado e passível de leituras a partir do momento em que é habitado. Na medida em que o corpo ocupa o espaço, ele ganha significados. Como se trata de teatro e não de cinema, observar o espaço arquitetônico "desocupado" é como observar o mundo de maneira cotidiana, a menos que o espaço sofra alguma intervenção identificável, como a iluminação. No caso do cinema, o simples efeito câmera, correspondente ao olhar do cineasta, já denota um modo particular, subjetivo, de olhar o mundo. Sem corpos ou luzes "habitando" o espaço, não há meios para efetuarmos alguma leitura, pois nenhum elemento se apresenta revelando o pacto no qual se estabelece que aquela arquitetura sirva, no momento, como espaço teatral. No cinema, a câmera recorta superfícies de espaço, que mesmo sem serem preenchidas por corpos, já se constituem como seleção para ser observada. Nesse teatro no espaço arquitetônico, a presença corporal é imprescindível, pois o pacto teatral depende do aparecimento de alguém que convide o espectador a uma releitura daquele espaço. 
Diz-se que no cinema o espaço está presente o tempo todo. É fácil concordar com essa afirmação uma vez que, desde o momento em que se liga a câmera, define-se claramente um recorte enquadrado, mesmo que seja um retângulo branco ou escuro. Por esse motivo, ao se referir ao corpo no cinema é necessário incluir o espaço. O corpo existe e apresenta-se constantemente em relação ao espaço. Podemos considerar, então, o corpo ou qualquer objeto presente no espaço como significante na composição estética do quadro. Não há acaso. Mesmo que não haja escolha consciente por parte do cineasta, o que se apresenta no filme está sujeito a leituras e significados. Por isso, sempre nos atentamos ao filme como objeto estético, independentemente das intenções do cineasta, o que ele diz sobre seu próprio trabalho.

Os Jogos do Olhar propõem que os intérpretes adquiram consciência de toda a estrutura da composição da cena. Ao mesmo tempo em que seus corpos são mídias - os ambientes de transformação e revelação das metáforas escolhidas - são também observados por alguém. A cena depende dos estados corporais dos intépretes e seus corpos estão presentes no material que é orquestrado. Portanto, essa Coleção de jogos interessa ao ator criador, consciente de suas escolhas, motivo pelo qual empresta seu corpo e voz como significantes das imagens compostas. Por outro lado, interessa ao encenador como primeiro observador, pois toda a criação acontece em função do olhar do espectador.

\footnotetext{
"A imagem se destaca; é pura e nítida como uma letra: é a letra daquilo que me machuca. Precisa, completa, minuciosa, definitiva, não me deixa qualquer lugar: dela sou excluído como da cena primitiva, que existe talvez apenas na medida em que é recortada pelo buraco da fechadura. Eis aqui portanto, finalmente, a definição de imagem de toda imagem: a imagem é aquilo de que sou excluído. Ao contrário daqueles desenhos ambíguos, nos quais o caçador está secretamente desenhado no emaranhado de uma folhagem, não estou na cena: a imagem está isenta de enigmas." (BARTHES, 2003, p.211, grifo meu)
}

A citação acima reafirma a qualidade dos Jogos do Olhar que se volta para a figura do encenador, que, por natureza, é excluído da imagem. Esse conceito colabora para a distinção dos papéis durante a escritura cênica. Assim 
como o encenador está excluído, o ator está incluído, é parte integrante e indispensável à composição da imagem. Porém, durante o processo de criação dessas imagens, cada jogador é observador também das imagens compostas pelos demais jogadores.

Portanto, consideramos o corpo como o lugar onde acontece a comunicação, a expressão, a catalisação das informações provenientes do ambiente. A idéia de Corpomídia é bastante relevante para verificar o contextosensitivo de cada corpo, definindo a informação que transforma. É a negação do corpo como recipiente, pois o veículo da informação nunca é passivo. As informações não são transmitidas pelo corpo, são transformadas em corpo. 0 corpo é visto como uma mídia de si mesmo (GREINER, 2005, p.129-133).

No caso da experimentação prática dos Jogos do Olhar, os jogadores eram convidados a identificar os comportamentos e as atitudes assumidas pelos personagens dos filmes selecionados pela pesquisa. Em seguida, no espaço cênico buscavam contaminar-se pelos ambientes, agindo ativamente na atribuição de significados aos lugares da cena. Experimentar um espaço pode ser comparado ao que disse o artista japonês Min Tanaka na coreografia "Locus Focus": "I dont dance in the place, I dance the place". Portanto, o espaço não é tomado como continente, nem como fundo em oposição à figura do corpo. É uma informação concreta para o jogador, um referencial constante, sempre presente. O espaço pode ser tomado como o meio, o que o atravessa, o que o faz mudar de atmosfera e alterar diretamente a matéria de seu corpo.

\section{(protocolo de Felipe Pitta)}

"Tenho a sensação de estar num formigueiro, cheio de caminhos a serem descobertos, tudo muito grande. Tenho a impressão de estar num lugar vazio, mesmo com tantas máquinas."

Apresentamos abaixo a análise de alguns personagens do filme "Toda Nudez será Castigada", de Arnaldo Jabor. Identificamos no filme uma explosão do corpo em direção ao espaço, ou seria o inverso? Escolhemos três personagens, portanto três corpos: Herculano, Geni e Serginho. Os três sofrem transformações ou transformam os espaços que ocupam, tornando-os 
verdadeiros prolongamentos de suas dimensões físicas. A questão é: corpo e espaço estão representados um no outro. Cada personagem pertence ao espaço no qual é apresentado e as mudanças de espaços detonam mudanças no ambiente de seus corpos (mídias). A atenção se volta para a interação entre as personagens e para a arquitetura exibida no filme.

\section{Toda nudez será castigada, de Arnaldo Jabor}

\section{a) Herculano}

O espaço que por excelência comporta Herculano é o casarão em que viveu com sua ex-mulher e depois com Geni, quando decide se casar com ela. A primeira cena (que é também a última) é a da chegada de Herculano no casarão, que dá início ao grande flashback que constitui a peça de Nelson e o filme de Jabor. A casa é povoada de retratos que o observa, vigia seus passos, como se a morte preenchesse as lacunas entre as paredes e as obras de arte. Há uma atmosfera fúnebre, de antiguidades. $O$ passado pesa no presente e 0 casarão se mostra como o palco da tragédia de Herculano. Ele penetra no tablado de seu teatro com a mesma formalidade do entorno, a casa é uma extensão de sua própria pompa. A trilha sonora escolhida por Jabor é um tango de Astor Piazzolla. A música registra a entrada triunfal de Herculano carregando flores e exibindo o alto nível de sua morada; e, ao mesmo tempo, anuncia a surpresa que será revelada pela gravação estridente de Geni.

Outro espaço que reflete essa personagem de maneira didática é aquele apresentado na cena em que Herculano está sentado diante de um espelho de três faces. A imagem revela a dúvida, a crise de identidade explicitada pela fisionomia do ator triplicada pelo reflexo do espelho. Essas projeções o fazem sofrer e questionar suas escolhas. A penteadeira de espelhos externaliza a luta entre a luz representada por Geni e o peso sombrio do passado que persegue Herculano.

Essa dúvida é exibida em outros planos em que os espaços de Herculano são invadidos por algum objeto colorido, iluminado, anunciando a chegada ou a presença de Geni. Na cena em que o personagem fala com ela ao telefone, ao som de Roberto Carlos, o plano de Herculano é negro, com exceção do orelhão amarelo de onde sai a voz de Geni. O único objeto colorido presente na cena simboliza a figura iluminada da amada. 
Outra cena em que a luz de Geni contamina Herculano é aquela em que os dois se encontram numa rua movimentada. Há um som muito alto que cria uma situação curiosa na cena; Herculano grita num raro esboço de sorriso: "tive uma idéia formidável!" A rua está cheia de gente, carros, barulho, é um lugar de transição, um entroncamento de caminhos, um sinal de mudança de rumos para o personagem. O espaço dá o contexto do pedido inusitado de casamento. Ele ri, gargalha, numa das poucas cenas em que abandona o ar cabisbaixo, sério, preocupado.

De volta ao casarão, o espaço que melhor traduz o personagem, há uma cena, durante a lua-de-mel antes do casamento, em que a câmera usa dois pilares para enquadrar o casal nu no cenário barroco. A moldura dos pilares descortina um espaço carregado, vermelho, de corpos contorcidos, entregues e camuflados à paisagem. Esse é o espaço que se confunde com a relação dos dois, um espaço teatral.

\section{b) Geni}

Nas primeiras tomadas em que a personagem aparece, ela está de costas, revelando o olhar misterioso que o cineasta dirige a Geni. O local que expõe a personagem é a boate, ambiente de penumbra, cuja iluminação provém de sua presença ensolarada. Geni também aparece no camarim diante de um espelho, justamente no momento em que Patrício lhe faz a proposta de Mefisto. A imagem duplicada de Geni exprime sua hesitação diante do desafio apresentado.

Em outra cena, na boate, Geni conversa com Patrício no balcão, sob forte luz vermelha. Ela e a boate se misturam, compondo um cenário de luzes e sombras. Geni tem olhos faiscantes. O ambiente traduz o fervor de dentro dela e a ansiedade pelo telefonema de Herculano. Depois dessa ligação, a boate ainda é o melhor lugar para que a frase "Patrício, eu tarei, tarei!" saia da boca grande de Geni.

Um espaço que reflete a transparência da personagem é o Rendez-vous da Laura. Na manhã seguinte ao seu primeiro encontro com Herculano, Geni dança, de roupão brilhante azul, na varanda multicolorida do cabaré. lluminada pela luz natural do sol, a personagem se torna mais leve, saltitante. O corpo dourado dança o espaço, o espaço invade o corpo. 
Quando a personagem chega ao casarão, os móveis estão cobertos por lençóis brancos, como os fantasmas que povoam o lugar. Sua primeira atitude é abrir as janelas e convidar a luz do sol para amenizar o ambiente opressor. No final, Geni é engolida por esse espaço e termina o enredo com os pulsos abertos, enrolada em um mísero lençol branco cheio de sangue. Um último vestígio de sol ilumina os olhos grandes que trocaram o brilho suburbano pela pompa de uma casa "herculana". Morta, paralisada, Geni pode ser vista como mais um dos objetos de arte expostos no casarão.

\section{c) Serginho}

O espaço que primeiro apresenta Serginho é o cemitério, onde encontra seu pai, diante do túmulo da mãe. Seu aspecto magro, franzino, vestindo um terno escuro, demonstra sua intimidade com a morte e seu apego ao passado. Seu corpo é rígido como o lugar destinado aos mortos. Sua opacidade só será perturbada depois da experiência trágica e transformadora do encontro com o ladrão boliviano na cadeia.

Há uma cena no hospital em que a imagem de Serginho aparece no fundo de uma porta entreaberta, entre seu pai e Geni. É a primeira vez que Serginho se coloca entre o casal, assumindo o papel de articulador da trama, antes desenvolvido por seu tio. Assim se iniciam as estratégias de Serginho para, afinal, encontrar o espaço onde seu corpo será identificado.

A cena em que Serginho e Geni namoram no conversível de Herculano revela o espaço manifestado do garoto: a auto-estrada. Esse é o lugar onde habita com maior familiaridade. Em fuga, o personagem se mostra mais confortável, com os cabelos ao vento. A auto-estrada simboliza a possibilidade de transformação de um Serginho pronto para iniciar sua história, livre da vingança contra o pai. Nesse momento, ele pode partir para o exterior acompanhado daquele que participou de sua grande epifania: o ladrão boliviano.

\section{Na Sala Branca - do treinamento ao aquecimento: diálogos com Klauss Vianna e seus "atualizadores"}

A Sala Branca, ou sala de ensaio comum do Departamento de Artes Cênicas da ECA/USP, teve um papel relevante no exercício contínuo de 70 
apropriação do espaço e, conseqüentemente, de apropriação do corpo. Por constituir-se como uma arquitetura simples, em comparação com os espaços visitados pelo Coletivo, a Sala Branca tornou-se um tubo de ensaio. Tudo o que se experimentava na sala, aplicava-se na complexidade de informações dos outros lugares. É o espaço primeiro, da excelência, com o qual o corpo se relaciona, onde ocorre o treinamento do corpo para a apropriação de outros espaços. Um espaço razoavelmente neutro, que pelo contraste, colabora na percepção e na escuta de outros espaços, inicialmente apenas arquitetônicos e, mais tarde, transformados em espaços cênicos.

Pensou-se em qualificá-la de "não-lugar", de acordo com o conceito desenvolvido por Marc Augé, a partir de George Benko (BENKO, George e STROHMAYER, UIf, 1997 apud BAUMAN, 2001, p.120) ${ }^{17}$.

[...] um espaço destituído das expressões simbólicas de identidade, relações e história: exemplos incluem aeroportos, auto-estradas, anônimos quartos de hotel, transporte público [...] Jamais na história do mundo os não-lugares ocuparam tanto espaço.

De certa forma, pode-se dizer que as salas de ensaio de diferentes lugares do mundo tendem a ser semelhantes, pois, ao construí-las, busca-se um ambiente neutro, com poucas informações e chão apropriado para o trabalho corporal. Às vezes, também são projetadas como lugares versáteis, aptos para receberem formatações variadas. Pensou-se também em qualificálas de espaços vazios, segundo citação encontrada no mesmo livro (KOCIATKIEWICZ, Jerzy e KOSTERA, Monica, 1999 apud BAUMAN, 2001, p.120) ${ }^{18}$.

[...] lugares a que não se atribui significado. Não precisam ser delimitados fisicamente por cercas ou barreiras. Não são lugares proibidos, mas espaços vazios, inacessíveis porque invisíveis. Se [...] o fazer sentido é um ato de padronização, compreensão, superação da surpresa e criação de significado, nossa experiência dos espaços vazios não inclui o fazer sentido.

${ }_{17}$ BENKO, George. Introduction: modernity, postmodernity and social science. In: BENKO, George e STROHMAYER, Ulf (org.). Space and Social Theory: Interpreting Modernity and Postmodernity. Oxford: Blackwell, 1997, p. 23-4.

${ }^{18}$ KOCIATKIEWICZ, Jerzy e KOSTERA, Monica. The anthropology of empty space. In: Qualitative Sociology. Springer, vol. 22, n. 1, p. 37-50, 1999. 
Não se sabe se a terminologia utilizada por Peter Brook também vem dessa fonte, uma vez que se trata de definições convergentes. Ao falar em espaço vazio, Peter Brook refere-se ao espaço recortado a partir da base de um tapete (como se o tapete fosse a planta baixa de um recorte tridimensional do espaço). Um espaço despido de cenários e objetos, dedicado ao jogo corporal dos atores. De certo modo, um espaço sem significados imediatos, dependente da presença do ator. O espaço aqui é considerado uma ferramenta, como para o mestre-encenador Peter Brook.

Sala Branca, não-lugar, espaço vazio, recinto importante para a percepção do corpo (individual), do coletivo e das significações já impressas nos lugares visitados. Essa afinação na percepção dos sentidos embutidos nos espaços é relevante, tanto para que o sentido seja ressaltado, quanto para que seja subvertido.

Algumas fontes garantiram o manancial de propostas corporais destinadas ao treinamento técnico e criativo dos jogadores "do olhar". Sobretudo os princípios técnicos desenvolvidos por Klauss Vianna e transformados em jogos específicos para a formação de atores por Lu Carion, com quem trabalhei durante sete anos ${ }^{19}$. A bagagem dessa técnica pode ser considerada a cartilha através da qual conduzi a preparação corporal dos atores-jogadores. Mais que um vocabulário, a Técnica Klauss Vianna tem sido um alfabeto com o qual aprendemos a escrever com o corpo, um modo de olhar para ele e, por extensão, para a voz, disponibilizando-os para a cena.

Além dos desdobramentos realizados por Lu Carion, aproximando o treinamento do jogo, a ferramenta da arte e o aquecimento da criação, levamos em consideração a experiência corporal vivenciada nas aulas de Neide Neves e Jussara Miller, duas "atualizadoras" da Técnica de Klauss Vianna. Para aprofundar a relação entre corpo e espaço, recorremos aos escritos de Laban, num recorte congruente aos ensinamentos de Klauss. Aproveitamos também a vivência com o ator Sotigui Kouyaté (do Théâtre des Bouffes du Nord, dirigido

\footnotetext{
${ }_{19}$ A pesquisadora integrou o OBARA - Grupo de Pesquisa e Criação em Teatro-Dança, iniciado como experimentação prática do mestrado de Luzia Carion Braz. Além da formação corporal, nasceu no OBARA a idéia de se compor a cena teatral a partir da observação cinematográfica, durante a primeira encenação do grupo ("Os Donos do Corpo") que se utilizou de fragmentos de roteiros de filmes de Glauber Rocha. Nessa ocasião, o grupo organizou uma Mostra de Vídeos do cineasta que reuniu professores e pesquisadores em debates que foram o ponto de partida de nosso estudo sobre a linguagem cinematográfica.
} 
por Peter Brook $)^{20}$, cujas propostas de jogo zelam pela atenção do ator ao momento presente, disponibilizando-se para a cena sem ansiedade, apenas colocando-se em relação com os outros jogadores. Para ajudar na coesão do grupo, utilizaram-se dois jogos aprendidos com o ator, os quais se tornaram parte do treinamento do grupo e foram incorporados à Coleção Jogos do Olhar - Corpo.

Os seguintes princípios da Técnica Klauss Vianna foram apresentados: disponibilidade das articulações, qualidade dos movimentos, apoio, peso, oposição, resistência e direcionamentos ósseos (algumas propostas estão descritas na Coleção Jogos do Olhar - Corpo). Klauss Vianna, em seu livro "A Dança", afirma que para ele "a configuração do espaço gerado por um movimento é mais importante que o movimento em si: é nesse intervalo que se passam a emoção, as projeções" (VIANNA, 2005, p. 92). Podemos dizer que o corpo em movimento cria espaços.

A observação do espaço físico era recomendada a cada encontro, seguindo o modelo proposto por Lu Carion. Como se analisássemos o projeto arquitetônico de um edifício, o enfoque estava nos referenciais concretos: dimensões (altura e largura), cores, materiais, proporções, temperaturas. Para "incorporar" a sala sensorialmente, realizávamos deslocamentos, ocupando-a de maneira uniforme. Em tais deslocamentos a pesquisadora propunha variações de andamentos e direções (frente, trás e lateralidades), experimentando alguns sons como forma de aquecer a voz e entender sua reverberação no local.

Apoios e articulações foram trabalhados simultaneamente. O primeiro passo é a percepção de que o movimento acontece pela transferência de apoios, pela mudança da base, da relação do corpo com o chão. Para isso, exploramos mudanças entre os níveis alto, médio e baixo. Movimentando as articulações uma a uma, com atenção às dobras corporais, induzimos a soltura da musculatura que sempre, nessa técnica, é conduzida pelos movimentos ósseos. "Klauss exemplificava em aula: 'pensar em osso traz alongamento e projeção, pensar em músculo pode trazer tensão"' (MILLER, 2007, p.84). O

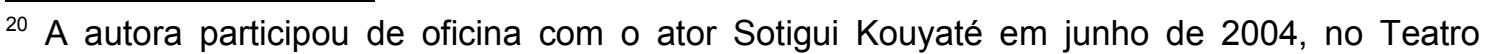
Fábrica São Paulo.
} 
trabalho com as articulações seguia o modelo da proposta descrita abaixo por Lu Carion (BRAZ, 2004, p. 95):

Lentamente, os alunos experimentavam uma proposta de exploração das articulações, isoladamente, seguindo uma condução simplificada. Experimentavam desde movimentos muito pequenos até os grandes movimentos com os pés (dedos, metatarso, tornozelo), joelho, coxofemoral, coluna vertebral (quadril e tórax), cintura escapular, braços (úmero-escapular, cotovelo e pulso), mãos (dedos e metacarpo) e pescoço/cabeça (cervical e caixa craniana).

Pequenas alterações foram acrescentadas à proposta descrita acima, como por exemplo, fechar os olhos durante o aquecimento corporal pela mobilização das articulações, pois de olhos fechados enfatiza-se a relação do corpo com o chão. Pela ausência do sentido da visão, a percepção tátil da relação do corpo com o chão torna-se mais evidente, colaborando para a utilização dos apoios. Assim, passamos a confiar mais no chão, pois ele passa a ser a única referência concreta.

Juntamente a essa proposta, exercícios foram conduzidos tendo como mote a movimentação parcial (uma articulação ou grupo articular) ou total (grande número de articulações). Algumas qualidades foram evidenciadas a partir dos seguintes verbos como proposições para a movimentação: dobrar, balançar e sacudir. O desenho no espaço também foi ressaltado pela variação "direto/reto e flexível/sinuoso" (Ibidem, p. 96).

A percepção do peso corporal é importante para o reconhecimento dos apoios utilizados pelo corpo, tanto em uma posição estática, quanto durante a execução de um movimento. A boa utilização dos apoios é fundamental para reduzir tensões corporais, encontrando a medida certa do esforço para moverse (tônus corporal) e projetar os movimentos e os sons no espaço.

Essa é a primeira fase, a da germinação, a da entrega. Só quando descubro a gravidade, o chão, abre-se espaço para que o movimento crie raízes, seja mais profundo, como uma planta que só cresce com o contato íntimo com o solo. (VIANNA, 2005, p. 93)

Introduzimos, também, os princípios da resistência e da oposição. Resistência pode ser considerada, segundo Lu Carion, "a intenção real, o 
esforço muscular para realizar um movimento encontrando uma força contrária, que dificulta sua concretização e demonstra a importância do contato com o chão como propulsor desse movimento". (BRAZ, 2004, p. 100). Exemplo disso é a proposta em que um jogador impõe resistência ao movimento de outro jogador, com as mãos. Sem impedir o movimento do outro, ele o leva a perceber os apoios necessários para mover-se e as partes do corpo que estão abandonadas (sem tônus). Essa resistência gera a oposição, que era exemplificada por Klauss Vianna da seguinte maneira: "Na ida de um gesto está contida também a vinda: é o que chamo de intenção e contra-intenção muscular" (VIANNA, 2004, p. 81). A oposição também foi trabalhada por meio do contato corporal entre dois jogadores, que usam o corpo do outro como apoio para "crescer" na direção oposta. "Com as oposições do corpo podemos dimensioná-lo em sua tridimensão, considerando-se os três planos anatômicos nos quais se realizam os movimentos: transversal, frontal e sagital" (MILLER, 2007, p.83).

Apresentamos também o princípio dos direcionamentos ósseos, desenvolvido por Klauss Vianna, baseado em estudos da anatomia do movimento aos quais se dedicou ao longo de toda sua vida. Klauss era um homem observador. Desde sua infância, o corpo era foco de seu interesse nas brincadeiras com o jardineiro de sua casa, nos esqueletos para estudos de anatomia de seu pai médico e nas aulas de balé clássico, até tornar-se um dos primeiros preparadores corporais do Brasil. Chegou a posar como modelo vivo para os quadros do pintor Guignard (mineiro, como ele). Depois de longos anos de observação e estudo, insatisfeito com as explicações para as posições do balé clássico, chegou aos direcionamentos ósseos, uma série de direções que alinham o corpo, ampliando os espaços entre as articulações e aumentando sua plasticidade ${ }^{21}$.

$$
\text { (protocolo de Pedro Melão) }
$$

"Neste ensaio houve uma troca de local, que ao menos para mim, gerou uma maior consciência de espaço. Primeiramente estávamos em uma das salas brancas, que a princípio não me parecia tão grande. Com o decorrer dos exercícios ela foi se tornando mais espaçosa e percebi que nem sempre a visão é capaz de nos dar uma noção exata de algo; é preciso

21 Para maiores esclarecimentos consultar BRAZ, 2004, MILLER, 2007 e ainda o site www.klaussvianna.art.br 
explorar com o corpo e com os outros sentidos. No outro local, um dos camarins do Teatro

Laboratório, outra coisa foi percebida: [...] para mensurar um espaço é interessante a exploração do mesmo nos 3 níveis (alto, médio, baixo)"

Verificamos que assistindo a cenas cinematográficas, enquadradas por uma câmera que obtém um objeto estético bidimensional, os jogadores percebem melhor o espaço tridimensional do teatro. A proposta levada a efeito era assistir a determinadas cenas cinematográficas, observando elementos específicos da composição. Esse exercício colabora para a consciência do intérprete de seu corpo como significante, bem como das relações dele com o espaço que ocupa. Apenas nos encarregamos de apresentar ferramentas que servem tanto para a observação dos corpos na tela, quanto para a expressividade de seu corpo no campo teatral. Conhecendo seu material criativo, o jogador pode fazer escolhas e optar conscientemente pelas imagens que compõe.

Partindo do pressuposto de que a posição da câmera é considerada o lugar de onde se avista a cena, desenvolvi um jogo. Nele, o ator encara seu corpo como um objeto tridimensional presente no espaço, cujas projeções geométricas configuram as três dimensões corporais. É como se o ator fosse posicionado em um triedro (encontro de dois planos, semelhante ao plano cartesiano - encontro de duas retas) e fosse convidado, pelo professorencenador, a observar as visões do seu corpo projetadas nas paredes e no chão. Trata-se de um desbodramento do exercício de espelho n.1 desenvolvido por Viola Spolin (SPOLIN, 1998, p. 55), denominado por mim de "Jogo do triedro". A partir dele, o jogador poderia responder às seguintes questões: que imagem de você é projetada para um observador posicionado de frente para você? E acima de você? E de lado? E o que observa alguém posicionado embaixo de você, caso o chão fosse de vidro? Essa última imagem corresponderia à planta baixa da posição do jogador. Tal imagem foi explorada no cinema no filme "Entr'acte", de René Clair (1924): uma bailarina dança sobre um suporte de vidro e o cineasta capta sua movimentação de baixo para cima.

O olhar que seleciona espaços faz dele uma categoria interdisciplinar. $\mathrm{O}$ olhar torna-se ponto de referência também para o corpo. Podemos imaginar quais as projeções das diversas visões do corpo no espaço, como sombras 
que produzimos no chão e nas paredes. Em geometria descritiva estuda-se a representação de um objeto tridimensional no papel que é bidimensional, através das projeções geométricas. Assim, ao ver a representação do objeto no papel, pode-se construir o objeto tridimensionalmente. Esses são exemplos de caminhos que levam do tridimensional ao bidimensional e vice-versa.

A consciência do próprio corpo é fundamental para a construção da identidade do grupo e para a formação de intérpretes presentes no "aqui e agora" da cena, não preocupados em representar personagens. Noções de progressões geométricas podem contribuir para que o jogador compreenda o volume de seu corpo, sua espacialidade e suas projeções no espaço. Consciente dos pontos a partir dos quais é observado, o jogador ressalta o lado do corpo de onde é visto, projetando seus movimentos e conseqüentemente, sua voz.

$$
\text { (protocolo de Adriane Escher) }
$$

"Uma coxofemoral travada. Um externo que se mexe com facilidade, mas que incomoda. Sensação desconfortante. Angústia? Os ombros também são travados, até mais. A minha postura não contribui em nada para a análise da movimentação. Sinto-me tão torta! [...] Fizemos então as palmas Sotigui, as palmas de tempo e contratempo, a palmas seguidas de flecha com mudança de lugar. Depois nos alongamos na parte térrea, utilizando o espaço como estímulo. Descobri que o intestino é ótimo para alongar a coluna, assim como massagear as pernas e sentir o peso do corpo. A escada aquece mais a parte superior do corpo, principalmente os braços. O cano maior eu gostei para a virilha. Enfim, pensei bastante nisso, neste encontro..." 


\section{Coleção dos Jogos do Olhar - Espaço + Corpo}

Apresentaremos a seguir mais uma lista de jogos que se referem a modalidades de jogos que focam a conscientização, o treinamento e a expressividade do corpo.

A roda de Sotigui:
Cada integrante da roda bate uma palma, buscando manter um pulso
contínuo. Na segunda rodada duas pessoas batem a primeira palma. Na
terceira, mais uma pessoa é agregada à primeira palma. Na quarta, mais uma
pessoa, e assim, cada integrante vai sendo agregado à primeira palma, até
todos baterem palmas juntos.

\section{Caminhadas e paradas de Sotigui:}

Todos os jogadores caminham pela sala, procurando ocupar o espaço de maneira uniforme. As pessoas devem parar uma por vez, sem uma ordem previamente estabelecida. Se duas pessoas pararem juntas, todas voltam a caminhar. Depois, uma a uma, todas voltam a andar, valendo a mesma regra (se duas pessoas saírem andando juntas, todas param novamente, até saírem todos na sua vez). Em seguida, duas pessoas saem andando por vez, sem combinar, nem sinalizar. Vale a mesma regra: caso uma ou mais pessoas (não uma dupla) saírem, todas param. Quando todos estiverem parados, duplas saem andando, valendo sempre a mesma regra.

$$
\text { (protocolo de Felipe Pitta) }
$$

"Tudo é muito grande, acaba virando um breu, pessoas se perdem no espaço ou o espaço perde as pessoas! Lá viramos máquinas, pássaros ou simplesmente pó? As cenas nascem de imagens, o tempo que temos é para isso mesmo, ver e fazer."

\section{Percepção sensorial do espaço:}

Jogo proveniente do treinamento desenvolvido no OBARA, a partir dos desdobramentos de Lu Carion sobre a Técnica Klauss Vianna. Consiste em observar o espaço partindo de referenciais concretos apresentados pela arquitetura (forma ou volume do espaço, combinação dos planos, desenhos geométricos - linhas retas ou curvas, cores, temperaturas, luminosidades, texturas, materiais - madeira, alvenaria, etc) e perceber quais as sensações do corpo diante dessas informações. 
Simultaneamente às primeiras experimentações para estimular os sentidos, foram propostos exercícios e jogos para a exploração do espaço. Em deslocamento com diferentes andamentos (lento, habitual e rápido), com delimitações espaciais (espaço grande e pequeno) e nas lateralidades (frente, trás, lado direito e esquerdo), o grupo deveria realizar a ocupação equilibrada do espaço. (BRAZ, 2004, p. 93).

\begin{abstract}
Maquete imaginária:
Jogo desenvolvido com o objetivo de perceber a complexidade dos espaços experimentados.

Depois de apreendida a materialidade do espaço, os jogadores fecham os olhos e procuram reconstruir todo o espaço na cabeça, como uma maquete imaginária. Dentro desse pequeno espaço imaginado, localiza-se a posição do próprio corpo do jogador, como se colocasse na maquete um pequeno alfinete representando-o. Pergunta-se ao jogador se ele conseguiria localizar e posicionar em sua maquete os outros jogadores. Quando, finalmente abrem os olhos, verificam se realmente se apropriaram do espaço (suas dimensões), se estão conscientes das proporções do próprio corpo em relação a ele e do posicionamento das demais pessoas. Realizar esse jogo na sala branca e nos diversos espaços pelos quais o Coletivo passou, funcionou como um treinamento na adequação do movimento e da voz em relação à dimensão espacial.
\end{abstract}

Os próximos seis jogos descritos foram vivenciados no OBARA - Grupo de Pesquisa e Criação em Teatro-Dança como desdobramentos para a aplicação da Técnica Klauss Vianna desenvolvidos por Lu Carion, que por sua vez os apreendeu com Rainer Vianna (filho de Klauss):

\title{
Círculo de Apresentação:
}

Todos os jogadores posicionados em círculo. Um deles caminha em direção a outra pessoa olhando em seus olhos, com precisão, assumindo seu lugar no círculo. Essa, por sua vez, escolhe outra pessoa do círculo e faz o mesmo.

Durante a caminhada, os jogadores dizem o próprio nome, apresentando-se a outra pessoa. Além de sustentar o foco do olhar, é importante manter a 
precisão na simples ação de andar, articulando bem o maxilar ao pronunciar o próprio nome e mantendo um volume audível.

Seguindo a mesma estrutura, o jogador diz o nome da pessoa em direção à| qual caminha, testando sua capacidade de memorização dos nomes em um jogo de atenção e escuta.

Na medida em que o exercício progride, é possível acrescentar mais linhas de trocas de posição simultâneas, aumentando a dificuldade de execução e, em conseqüência, o nível de atenção e escuta.

\section{Associação entre percepção do movimento e nome da articulação:}

Seguindo a estrutura do exercício anterior, incluir movimentos parciais (com apenas uma articulação ou grupo articular) durante o percurso entre a posição inicial do círculo e a pessoa escolhida. Durante a caminhada experimenta-se dizer o nome da articulação movida, associando o movimento ao modo de dizer o nome.

\section{Movimentos Parciais e Totais: \\ Em roda, um jogador deve explorar um movimento parcial (envolvendo apenas uma articulação). Na seqüência, todos os jogadores (incluindo aquele que propôs) repetem o movimento juntos, como se fossem um eco do proponente. O jogador seguinte da roda propõe um movimento total (envolvendo muitas articulações); todos os jogadores o repetem em eco. O próximo jogador propõe um movimento parcial e assim sucessivamente, alternando movimentos parciais e totais.}

\footnotetext{
Mapa de apoios corporais:

Convidar os jogadores a observarem as partes do corpo que tocam e as partes do corpo que não tocam no chão, antes e depois de atividades que mobilizem as articulações ou provoquem certo cansaço corporal (um jogo mais dinâmico, por exemplo, sem necessariamente recorrer ao artifício da exaustão). É importante registrar o enfoque da Técnica Klauss Vianna na percepção consciente dos movimentos. Geralmente, quando se trabalha a
} 
exaustão, perde-se a consciência das partes do corpo envolvidas no movimento.

Peço que se deitem no chão e observem-se: a intensidade da respiração, a temperatura, o que estão sentindo, o que não estão sentindo, o que é agradável, o que não é agradável. Peço ainda que imaginem um giz traçando o desenho do corpo no chão, como um mapa deles mesmos, no qual as várias regiões diferenciam-se: traços mais fortes, em que o contato é mais pesado ou profundo, mais delicados onde o contato é menor, ausência de linhas nas regiões em que o corpo não toca o chão. (VIANNA, 2005 p. 137).

\section{Contato da pele com o chão:}

Estimular a pele através do contato com o chão, variando a intensidade das pressões, ora esfregando-a no chão, ora roçando-a delicadamente, ora massageando-a vigorosamente. Nem sempre as tensões são dissipadas com força e rapidez, geralmente a suavidade e a lentidão geram mais soltura muscular do que a força e a rapidez. Nessa proposta faz-se necessário uma sala com chão apropriado ao trabalho corporal. Em nossa experiência, realizamos esse tipo de trabalho apenas na Sala Branca (sala de ensaios do CAC/ECA/USP).

\section{Bexigas para soltar o peso:}

Utilizar bexigas cheias de ar, como instrumento de trabalho, posicionadas sob os joelhos (um de cada vez), o sacro e as escápulas (uma de cada vez), para soltar o peso das partes do corpo. Proposta que requer chão apropriado, no nosso caso, a realizamos também na sala de ensaio.

Os alunos iniciavam um processo de reconhecimento do peso real do corpo pelo relaxamento conduzido de cada parte específica (foi muito usada a imagem de um volume, de uma massa de sorvete que derrete e se esparrama pelo chão). O termo iniciar, nesse caso, é proposital, pois muitos alunos encontram dificuldades para soltar e perceber o peso do seu corpo em conseqüência de grandes tensões musculares. (BRAZ, 2004, p. 98).

Soltar o peso das partes do corpo: 
Em situações em que o chão não for apropriado (caso da Hidráulica e de uma sala de aula comum, na vivência do Coletivo - Jogos do Olhar), propor a soltura das partes do corpo, de pé. Parados, começar soltando o peso da cabeça e, depois, da cintura escapular. Em deslocamento, perceber o peso dos braços (às vezes correndo e colocando-os em diferentes posições) e cada uma das pernas (inicialmente segurando cada perna com os dois braços, para reconhecer o peso dessa parte do corpo).

\section{(protocolo de Felipe Pitta)}

"O corpo marca a areia assim como em cada ponto o corpo expressa uma sensação, em cada ponto, um ponto de vista.

Corpo - unidade completa que se processa e se une novamente.

O peso da cabeça, dos braços, cada parte um peso, cada peso um incômodo, desmonta e monta."

\section{Jogo do espelho narrado:}

Desdobramento do exercício de espelho n.1 de Viola Spolin (SPOLIN, 1998, p. 55). Cada jogador define uma seqüência de movimentos para ir até o nível baixo e voltar ao alto. Quando se consegue repetir com precisão a seqüência de movimentos, formam-se duplas. Um jogador mostra sua seqüência de movimentos para sua dupla, narrando as mudanças de apoio que efetua para mudar de posição, atentando-se para narrar apenas os "novos" apoios e não aqueles já utilizados na posição anterior. O espelho da dupla reproduz os movimentos e executa-os repetindo a narração proposta pelo colega simultaneamente às mudanças de posição.

\section{Jogo do triedro:}

Desdobramento do exercício de espelho n.1 de Viola Spolin (SPOLIN, 1998, p. 55), como se o jogador estivesse dentro de uma caixa espelhada.

O jogo foi elaborado com o objetivo de tornar os jogadores conscientes das projeções de seus corpos para espectadores posicionados em diferentes pontos de vista. Um jogador propõe movimentos (improvisados ou préestabelecidos, como no jogo anterior) que são reproduzidos por três ou quatro 
jogadores posicionados ao redor do jogador central. Cada jogador espelha uma vista do corpo copiado, fisicalizando as projeções desse corpo no espaço. 


\section{Imagem do corpo só \& imagem do corpo coletivo}

"Apêndice:

Olho é uma coisa que participa o silêncio dos outros

Coisa é uma pessoa que termina como sílaba

O chão é um ensino."

Manoel de Barros

Dois jogos podem ser considerados "chaves" para a inscrição de cenas teatrais em um espaço arquitetônico qualquer, de acordo com as explorações de procedimentos cinematográficos aqui apresentados: o jogo do enquadramento de Ryngaert e o jogo de composição de fotografias. A associação desses dois jogos define recortes espaciais como se fossem enquadramentos teatrais, aos quais correspondem posições específicas para o olhar dos espectadores. Os enquadramentos teatrais são recortes espaciais identificáveis pelos observadores, seja pela presença de alguma barreira arquitetônica, seja por meio de recursos de iluminação. A máscara de papel, utilizada como ferramenta para recortar o espaço, familiariza o jogador com uma observação fragmentária do espaço, como se brincasse com uma câmera de fotografia ou vídeo. No entanto, como revelar o enquadramento teatral sem o auxílio desse artifício? Pois o que caracteriza a construção do visível no teatro é a observação das imagens diretamente, sem a mediação de uma câmera. Não pretendemos com essa afirmação definir um estatuto para a cena teatral, apenas discorrer sobre os meandros que envolvem a fixação do quadro teatral, ou a mise-en-cadre de uma encenação fora da sala convencional.

A apresentação das possibilidades de "superenquadramento", específicas às imagens criadas com o auxílio da câmera (ou máscara de papel), orientou os olhares dos jogadores na busca por barreiras ou limites sugeridos pela própria configuração da arquitetura. Nesse estudo a máscara de papel simboliza uma câmera. Todavia, ao transformar esse recorte em enquadramento teatral, o espectador o observa sem o quadro vazado da máscara de papel (ou a câmera). Ao contemplar um espaço a olho nu, não sabemos qual fatia dele será isolada para a cena. Por isso, lançamos mão de obstáculos presentes no espaço e na iluminação, fundamental para que o espaço seja revelado parcialmente. 
A partir de um mesmo ponto de vista, muitos enquadramentos são possíveis. Da mesma forma, cada enquadramento esconde múltiplos quadros que só virão à tona por meio da experimentação corporal do espaço. Na Hidráulica, pela amplitude da área observada, dividimos em três momentos a pesquisa do espaço: pontos de vista do térreo, pontos de vista da plataforma 1 ou dos corredores e pontos de vista das plataformas 2 e 3 . Organizados desse modo, os jogadores tiveram períodos de tempo estabelecidos para investigarem o espaço através da máscara de papel e selecionarem enquadramentos. Em um primeiro momento, os jogadores mostravam uns aos outros as sugestões de posição do público e quadro observado, mas apenas alguns enquadramentos eram realmente explorados. Geralmente, excluíamos espaços que comportassem um número pequeno de espectadores, lugares que oferecessem riscos ao público e também locais em que o recorte arquitetônico não seria preciso sem o auxílio da máscara. O jogo do enquadramento revela inúmeras possibilidades, no entanto, é importante a seleção de um número restrito de enquadramentos nos quais muitas fotografias sejam experimentadas. Notamos, na prática, que mais vale insistir na composição de várias fotografias no mesmo enquadramento, que explorar poucas fotos em vários enquadramentos.

No momento de ocupar o espaço, os atores devem mostrar o enquadramento selecionado por meio do posicionamento de seus corpos. A regra, descrita na Coleção de Jogos do Olhar, consiste em ocupar o espaço um participante por vez, sendo que, em alguns recortes, a primeira pessoa a se posicionar já compõe uma fotografia precisa. Durante a proposição de títulos para as imagens propostas, constatamos que a responsabilidade pela significação recai sobre a atitude corporal. Sem a presença do corpo, o recorte espacial não revela muitas opções de significação. Por isso é tão relevante dedicar-se durante um bom tempo à composição de fotografias, sugerindo variações de posição do corpo na relação com a arquitetura (nível no espaço, tônus corporal, posição do olhar), pois a leitura das fotografias criadas depende dos significados propostos pelos corpos presentes no espaço.

Outro fator a ser observado é a combinação de muitos corpos no enquadramento, como na composição de um tableau ou uma paisagem. 0 tableau equivale a um quadro pictórico bem composto, uma cena absorvida em 
si mesma, manifestando a produção de sentido. Um recorte visual corresponde a um recorte de idéias, mesmo que uma única imagem desencadeie leituras diversas. Desse modo, atribuímos ao corpo a responsabilidade pelos significados imanentes no espaço. Ele é o meio através do qual o espaço se revela, seja pela presença de apenas um corpo, seja pela presença de uma coletividade. A disposição dos corpos entre si reitera um comportamento coral, revela tensões ou reafirma posições individuais dentro do coletivo. $\mathrm{Na}$ composição do tableau podem-se utilizar referenciais geométricos, sugerindo uma paisagem que emerge do encontro dos corpos com a locação. Mesmo que se trate de uma abordagem abstrata, é relevante ressaltar que a combinação dos elementos presentes na cena pode criar atmosferas e não necessariamente situações definidas.

Para lidar com esse tipo de concepção, é preciso estudar os agrupamentos de pessoas, os coletivos presentes na cena. Jean-Pierre Sarrazac, citando Hans-Thies Lehmann, afirma que a coralidade é uma espécie de categoria do pós-dramático. Segundo ele, coralidade e monólogo substituem o diálogo dramático nesse teatro de imagens, eminentemente cenocêntrico (SARRAZAC, 2003, p. 28-29). A aparição de coros no filme "O Dragão da Maldade contra o Santo Guerreiro", de Glauber Rocha é emblemática das inúmeras possibilidades de representação das massas. Muitos aspectos podem ser percebidos: desde os desenhos que juntos compõem no espaço, até a ordem de importância das personagens, dependendo de sua posição no quadro. Inicialmente, na História do Teatro o coro caracterizava-se por realizar o comentário da cena. Atualmente, reaparece a função coral e não necessariamente o coro. As coralidades contemporâneas têm caráter discordante, apresentando corpos, textos e intenções, muitas vezes, conflitantes. O estudo do coro resultou na coleção de variadas propostas de jogo como estímulo para sua formalização. Esses jogos estão relacionados na próxima listagem de Jogos do Olhar.

O protocolo abaixo revela a proporção que essas modalidades de jogo tomaram para os participantes do Coletivo, uma vez que questionam a 
realização da encenação no Centro Tecnológico de Hidráulica por colocar em risco a utilização dos coros em cena.

(protocolo de Adriane Escher)

"A Paulinha disse e concordo: aqui não cabe coro, é um lugar de indivíduos que se camuflam. Para se destacar aqui é preciso muito, porque senão o corpo desaparece no espaço. Isso foi o contrário dos demais espaços. A qualidade daqui é te fazer sumir, se anular. Vi poucas imagens aqui. Parece que tudo já está carregado de muito significado. $O$ barulho cansa, fica como um zunido. Falar também exige esforço. Tudo fica meio perdido. Lembra-me a firma do meu pai, algo chato e falso, verde e cinza..."

Filmado no sertão da Bahia, em 1969, a obra de Glauber Rocha é rica em composições visuais geometricamente elaboradas. Abaixo, algumas cenas são descritas e nosso foco de atenção se volta para o posicionamento de um corpo ou de uma coralidade no espaço ficcional. Também observamos a relação da cena com a câmera, sua movimentação diante da ação, o que na transposição para o teatro representaria a relação entre atores e espectadores. Os planos não são frutos do acaso, são pensados, organizados sob a influência de um olho cuidadosamente treinado. Glauber é alegórico, explícito em suas escolhas. Podemos perceber os efeitos do seu olhar nos fragmentos selecionados abaixo.

\section{O Dragão da Maldade contra o Santo Guerreiro, de Glauber Rocha}

A - Plano-seqüência em que pequenos movimentos da câmera acompanham Coirana, o cangaceiro. A cena é estruturada em forma de um tableau que apresenta o contexto do filme. Coirana, o Santo Guerreiro, está posicionado no centro de uma arena formada pelos beatos que assistem à sua performance. Eles estão sentados no fundo da cena em degraus diante das fachadas das casas do lugarejo: Jardim das Piranhas. Alguns cangaceiros estão sentados no chão, dispostos geometricamente (em losangos) para preencher a arena. $O$ professor, delegado Matos, a Santa (lansã, Santa Bárbara) e Antão (Oxossi, São Jorge), sucessivamente, descrevem trajetórias circulares em torno de Coirana. Há um pequeno movimento da câmera que busca o olhar cego do coronel Horácio acompanhado por seu guia, Batista. O movimento da câmera, sugerindo o olhar do espectador, descreve, sem palavras, a situação de tensão 
em que se encontra a vila. Uma ação é apresentada, com começo, meio e fim. Do momento em que a câmera mostra Coirana no centro da arena até o momento em que ela mostra o coronel, uma situação concisa é definida. A composição do tableau revela as ordens de importância. Coirana está no centro. Os cangaceiros estão sentados em um círculo ao redor dele. Os beatos ao fundo fecham a arena, junto com as casas. As personagens e a ordem de sua aparição, circundando Coirana, revelam sua relevância e anunciam algo que está por vir dentro da trama.

B - Plano em que Coirana é ladeado pela Santa e Antão, ambos empunhando armas pontiagudas que passam no meio de seus rostos, dividindo-os simetricamente. As armas dos santos formam duas linhas paralelas verticais que ladeiam o rosto de Coirana como uma moldura de metal, que o protege. A composição visual do quadro foi preparada para a emissão da fala de Coirana. A imagem suscita inúmeras leituras: um cangaceiro entre dois santos armados. Ela carrega em si o paradoxo entre a fé e o sentimento de vingança, características típicas dos cangaceiros, justiceiros fora da lei.

C - Plano que mostra fachada da casa do coronel Horácio, num recorte que seleciona uma porta e uma janela. A câmera está fixa e o enquadramento sugere um palco, "espaço circunscrito". Antônio das Mortes atravessa a cena da esquerda para a direita e volta. Laura aparece na janela e acompanha com os olhos os movimentos de Antônio; ele a ignora. Em seguida, entra em cena o delegado, pela porta da fachada da casa, revelando o seguimento do fundo do campo cinematográfico. Com sua chegada, Antônio se posiciona na extremidade direita do quadro. Entram o coronel e o guia, também pela porta, e permanecem na outra extremidade do quadro. O delegado está entre Laura e o coronel.

O posicionamento dos personagens no enquadramento é significante, revelador de suas atitudes e personalidades. O percurso descrito por Antônio das Mortes demonstra sua espera e sua condição, antecipando a fala do coronel ao encerrar o plano: "Jagunço de graça, traz desgraça." Antônio está à espreita: ronda a casa, cabisbaixo, com a espingarda em punho. Laura destoa da cor local. Traja uma roupa roxa esvoaçante e permanece o tempo todo 
dentro da casa, protegida pela propriedade do marido. Esconde-se e revela-se, semi-escondida pelo batente da janela. Seu olhar vivo está atento a tudo, arquitetando estratégias que denunciam sua insatisfação e acomodação.

O olhar direcionado à cena é teatral, pois a fachada da casa funciona como cenário teatral, omitindo a profundidade de campo. Ao caminhar no revés da tendência do cinema moderno (que revela a profundidade de campo), o cineasta apresenta a dureza da fachada da casa como se apresentasse o problema da posse da propriedade privada. O espaço do coronel é o espaço privado, delimitado por paredes e cercas; oposto ao espaço dos beatos e cangaceiros, os campos abertos e a encosta da montanha, que anunciam o desejo de uniformidade na utilização da terra.

D - Plano-seqüência delimitado pelo som da cantiga "ó Cosme e Damião chegou...". Beatos, Santa, Antão, Coirana e cangaceiros se deslocam em coro da direita para a esquerda do quadro. Vez ou outra, o padre cruza a tela no sentido oposto. A câmera se movimenta lentamente no mesmo sentido. No entanto, só é possível perceber esse movimento devido à mudança da paisagem de fundo e ao desfile de olhares atrás do coro, acompanhando a cena. O movimento coral é reforçado pelo movimento da câmera, contrário ao sentido natural do olhar ocidental (da esquerda para a direita), causando desconforto. A atitude do padre, contra a corrente do coro, traduz suas inquietações místicas, questionando os caminhos da fé. A cena é vista pelos "protagonistas" que estavam na cena da fachada da casa do coronel. Esses personagens não se envolvem nesse círculo religioso, permanecem distanciados, apenas observando.

E - Plano da Santa enquadrada em uma paisagem seca, agreste. O diretor usa o corpo da Santa sentada ao pé de uma árvore para contornar o quadro. Ela compõe com a paisagem como se o espaço existisse a partir dela. O branco do seu vestido se confunde com o branco da areia seca. Os arbustos e plantas da caatinga têm os tons de seus adornos: ocres, cobres, amarelos. Só alguns verdes resistem à seca, como se anunciando a chegada de Antônio das Mortes. Ele traz mudança, movimento e redefinição de percursos. O seu "das mortes" simboliza a transcendência da morte, apesar de para alguns significar 
uma interrupção, um ponto final. O posicionamento do personagem (Santa) dentro do quadro cria significado. Seu corpo em consonância com o espaço representa sua simbiose com a natureza, de onde evoca poderes premonitórios. A Santa reclama a Antônio das Mortes a perda dos seus. Sua voz uniforme causa a impressão de entoar um mantra ao enunciar o "destino" de Antônio.

A composição da cena teatral pela imagem imobilizada remonta à composição do fotograma, contrariando "a essência sagrada do cinema: a imagem em movimento" (BARTHES, 1990, p.59). Em consonância com Bob Wilson, a proposição de se partir de fotografias "vivas" revela um nexo entre fotografia, teatro e cinema (nesse caso, pelo fotograma). A composição da cena pela imobilidade do corpo ressalta a manifestação da corporeidade. "O corpo passa a ocupar o ponto central não como portador de sentido, mas em sua substância física e gesticulação. O signo central do teatro, o corpo do ator, recusa o papel de significante" (LEHMANN, 2007, p. 157). No teatro pósdramático a corporeidade é auto-suficiente, seja em um estado de imobilidade, seja em movimento. O teatro atual valoriza o fenômeno que ocorre no corpo, em sua expressividade e conseqüente movimentação e interação entre corpos, como profetizou Antonin Artaud. Prova disso é a aproximação cada vez mais evidente entre teatro e dança na contemporaneidade. Se por um lado, o teatro "falado" cria partitura de movimentos, verdadeiras coreografias, ainda que não seja propriamente uma dança, o conceito de dança ampliou-se significativamente. A dança abandonou a estrutura narrativa e psicológica e a produção de sentido dramático. Exemplo disso é o trabalho de Maguy Marin, recentemente apresentado em São Paulo (outubro de 2008) "Unwelt". Nele, os bailarinos executam seqüências de ações corriqueiras (acordar, tomar café, limpar o chão), sem apresentar um movimento sequer dançado.

Citando Eisenstein, Roland Barthes fala do "dentro" do plano sobre as possibilidades da montagem, sobretudo no que se refere à dramaturgia visual. O cineasta russo atribui aos elementos internos ao plano, que dizem respeito ao fotograma, o centro de gravidade da montagem e não ao choque entre planos. 
Sem dúvida, não há nenhuma montagem audiovisual no fotograma; mas a fórmula de S. M. E. é geral, pois que inaugura um direito à disjunção sintagmática das imagens, e requer uma leitura vertical da articulação. Além disso, o fotograma não é uma amostra [...], mas sim uma citação. [...] filme e fotograma encontram-se em uma relação de palimpsesto ${ }^{22}$, sem que se possa dizer que um é o em cima do outro, ou que um é extrato do outro. (BARTHES, 1990, p. 59, grifo do autor)

Recorremos a Eisenstein na busca por diálogos na composição de imobilidades como ponto de partida para cenas em movimento. No entanto, somos conscientes da ideologia implícita à obra do cineasta, a qual não será abordada nesse estudo. Sua formulação sobre o fotograma interessa na medida em que dá autonomia ao quadro, como unidade composta e recheada de sentidos obtusos que vão além do sentido óbvio (temático), para utilizar terminologia elaborada por Roland Barthes.

De volta ao jogo teatral propriamente dito, nas situações que experimentamos com o Coletivo aconteceu de os jogadores, no jogo de composição de fotografias, ignorarem o espaço e proporem uma imagem que poderia ser apresentada sobre qualquer fundo. Como se a imagem de seus corpos uma vez recortada e colada sobre um fundo branco ou outro lugar qualquer, se sustentasse independentemente das informações contidas no espaço. Esse tipo de ocorrência revela a necessidade dos jogadores de ilustrarem o espaço, recorrendo a clichês da representação e à criação de fábulas. Tanto como jogadores quanto como espectadores é comum esse tipo de atitude; pode-se dizer que somos treinados cotidianamente para ler "estorinhas", mesmo onde elas são ausentes. Atualmente, há uma tendência à fabulação, desde os comerciais de televisão até a espetacularização da vida privada. Portanto, ao compor fotografias no enquadramento teatral, recomendava que os jogadores delimitassem ou apresentassem o espaço, sem interpretá-lo, sem forjar alguma significação. Expondo-se como materialidade, substância física e gesticulação, retomando citação de Lehmann, e permitindose certo grau de abstração na composição do quadro, o jogador de dentro da cena permite que o jogador de fora da cena exercite sua capacidade de leitura. As imagens criadas a partir da friç̧ão dos corpos com o espaço convidam o

${ }^{22}$ Palimpsesto: papiro ou pergaminho cujo texto primitivo foi raspado, para dar lugar a outro. (HOUAISS, 2001, p. 2111) 
leitor a olhar poeticamente para as cenas, buscando uma percepção metafórica da composição. Ao contestar a primazia da fábula também na apreciação das imagens, possibilitamos a convivência de leituras diversas, ampliando as alternativas de desenvolvimento das imagens estáticas em cenas dotadas de movimento.

Essa proposta nos aproxima de outro conceito elaborado por Roland Barthes no livro "A Câmara Clara". Ao referir-se à fotografia fala em operator (quem fotografa), spectator (quem observa a fotografia) e spectrum (quem posa para ela). Refere-se a essas práticas como três emoções ou intenções: fazer, olhar e suportar, respectivamente. Tais conceitos, utilizados para discutir a fotografia, podem ser aplicados à representação teatral. Para isso, basta experimentar a inversão de alguns termos. O operator seria o encenador; 0 spectator, o espectador de outra imagem visível (teatral ou cinematográfica) e o spectrum seria associado ao papel do ator. Como o autor não chegou a experimentar o ato de fotografar, discorreu sobre duas dessas práticas: a do sujeito olhado e a do sujeito que olha.

Diante da objetiva, sou ao mesmo tempo: aquele que eu me julgo, aquele que eu gostaria que me julgassem, aquele que o fotógrafo me julga e aquele de que ele se serve para exibir sua arte. Em outras palavras, ato curioso: não paro de me imitar, e é por isso que, cada vez que me faço (que me deixo) fotografar, sou infalivelmente tocado por uma sensação de inautenticidade, às vezes de impostura (como certos pesadelos podem proporcionar). Imaginariamente, a Fotografia (aquela de que tenho a intenção) representa esse momento muito sutil em que, para dizer a verdade, não sou nem um sujeito nem um objeto, mas antes um sujeito que se sente tornar-se objeto: vivo então uma microexperiência da morte (do parêntese): torno-me verdadeiramente espectro. (BARTHES, 1984, p. 27, grifo do autor)

Considerando-se as imagens uma intersecção entre corpos e espaço, pode ser angustiante para o ator emprestar-se para a leitura do spectator, como o spectrum de Barthes. Ele discorre sobre a sensação de tornar-se objeto ao ser fotografado, mas não considera que o objeto da fotografia, no caso da transposição para a prática do ator, é o responsável pela composição da imagem. É o ator quem decide, juntamente com os outros atores, no 
território do jogo, como ou em que situação se apresenta como objeto. Encarado por essa ótica, o ator não é nem um pouco objeto. Vale afirmar que agindo como ator criador (chamado por Matteo Bonfitto de ator-compositor), o jogador é o sujeito da escritura da cena. Sobretudo em um processo criativo em que não se parte de texto prévio e não se trata da concretização de uma encenação imaginada pelo diretor. $\mathrm{O}$ ator-jogador exercita seu direito de ser sujeito. Verificamos que o sentir-se objeto ou sentir-se sujeito no seio de uma criação coletiva são sensações oscilantes, partilhadas entre as funções dos atores e da encenação. O ator é sujeito na criação da cena, pois é ele quem propõe a ocupação espacial e cria as fotografias, embora ao tornar-se imagem passe a ser "lido" como objeto. Do mesmo modo, o encenador é sujeito ao propor os pontos de partida para a criação e é objeto ao receber as imagens compostas pela coletividade. O encenador pode ser considerado o olho mecânico que seleciona, organiza, "opera" as imagens relacionando-as ou colocando-as em conflito.

Nesse contexto, as temáticas nasceram das imagens, não o contrário. Por isso, era importante que os jogadores propusessem imagens a partir da relação concreta com o espaço e o ocupassem delimitando-o, revelando seus contornos. No jogo de composição de fotografias, depois da entrada do primeiro jogador, outros entravam um por vez, complementando a figura inicial, levando em consideração o que estava sendo proposto. De maneira indireta, pois não havia elaboração prévia e sim o choque das ocupações espaciais sobrepostas, os sentidos criados na relação com as locações eram revelados aos demais jogadores, encarregados de nominar as fotografias, atribuindo-lhes títulos. O corpo apresentava o espaço, não se impunha sobre ele, desvelando sentidos e possibilitando ressignificações.

(protocolo de Anna Dulce)

"Foi definitivamente a parte mais divertida e talvez mais desafiadora. Quando experimentávamos destacar o corpo no recorte do espaço escolhido, eu não tinha a menor idéia de como aquelas fotografias poderiam ser encenadas."

Curiosamente, cada momento do processo criativo da encenação correspondeu a um momento similar na estruturação do Coletivo - Jogos do Olhar. No momento anterior à escolha da locação, o Coletivo não tinha um corpo definido, a fluidez foi sua maior característica. Ou seja, enquanto fomos 
nômades, o Coletivo foi fluido. Na medida em que fixamos residência na Hidráulica, o corpo do agrupamento definiu-se. Os horários passaram a ser uniformes e comuns a todos, eliminando a possibilidade de haver ensaios não freqüentados por todos os componentes.

No início da pesquisa, definimos três horários de ensaios semanais; entretanto, cada componente deveria participar de no mínimo dois. Com a mudança de característica do Coletivo para sedentário, os integrantes alteraram as regras, uniformizando os ensaios e chegando a dias e horários de trabalho possíveis para todos. Todos deveriam estar presentes o mesmo número de horas: eliminaram a possibilidade de participações eventuais de determinados jogadores. Tal possibilidade restringia-se a outras funções: iluminação, programação visual, figurinos e documentação audiovisual. A questão espacial deve ser considerada, pois a relação desse grupo de pessoas com um lugar específico definiu critérios para a gestão do Coletivo. Portanto, ao afirmar que Coletivo é questão de tempo, refiro-me à duração da experiência e à concentração do agrupamento enquanto dura certa empreitada. Não me refiro à mobilidade na participação, o que constituiria uma formatação amorfa de Coletivo, que receberia a cada encontro participantes distintos. A questão do espaço, no entanto, é relevante na constituição da identidade grupal.

$$
\text { (protocolo de Kátia Lazarini ) }
$$

"A fase de experimentação do espaço pareceu muito apropriada por parte da coordenação, que transmitiu confiança e clareza nas proposições. Foi ainda um momento do grupo se conhecer e identificar seus participantes. Os jogos propostos traziam regras claras que não exigiam experiência ou conhecimento teatral prévio."

\section{Coleção dos Jogos do Olhar - Espaço + Corpo}

Essa parte da Coleção de Jogos do Olhar apresenta modalidades de jogo colecionadas e desenvolvidas com o objetivo de formalizar coros na cena teatral. Provenientes de fontes diversas, ao serem levados para a cena, esses jogos ganharam estatutos de "coralidades" diversas. Todas as propostas abaixo foram experimentadas no Coletivo, ainda que nem todas tenham sido 
levadas à cena. No entanto, o treino de coro foi muito eficaz para a percepção da coletividade por parte dos jogadores.

\begin{abstract}
Coro de pulso comum
Trata-se de um desdobramento do jogo tradicional "Siga o Mestre". A primeira vez que tive acesso ao jogo foi nas aulas da professora Neide Neves.

Todas as pessoas ao caminharem marcam um pulso, que pode ser percebido pelo contato do pé com o chão. Esse pulso pode ser percebido mesmo que os passos não provoquem nenhum som, é uma cadência sugerida pela alternância das pernas. Depois de perceber o próprio pulso, cada jogador busca aproximar-se de alguém que tenha o pulso parecido com o seu. Depois, aproximar-se de alguém que tenha o pulso muito diferente. Provavelmente esse encontro será breve, pois com pulsos diferentes, essas pessoas tenderão a se afastar. No entanto, procura-se manter a conexão com essa pessoa (mais veloz ou mais lenta) mesmo à distância, seguindo-a ou escapando dela. Os jogadores podem perceber as diferentes sensações de estar próximo de alguém com pulso similar e de tentar manter-se conectado com uma pessoa de pulso muito diferente do seu. Entre uma proposta e outra, volta-se ao próprio pulso, notando sua zona de conforto. Em seguida, o grupo todo busca encontrar um pulso comum. Nesse acordo, sem palavras, todos cedem: alguns aceleram e outros desaceleram seu próprio andamento, buscando alcançar um pulso comum. Uma pessoa propõe uma alteração no pulso, o que significa alterar o andamento da caminhada e todos a seguem como no conhecido jogo "Siga o Mestre". Variações de direções (frente, trás e lados) também são bem-vindas. Deve-se evitar sobrepor movimentos dos braços aos movimentos de deslocamento, pois eles podem confundir o jogador que pensa ter alterado o pulso ao introduzir palmas à caminhada, por exemplo. O mestre varia ao longo do jogo. Caso dois mestres proponham ao mesmo tempo, o grupo tacitamente escolhe um deles.
\end{abstract}


Outro desdobramento do jogo "Sida o Mestre". Todos os participantes caminham pelo espaço. Com a instrução "a primeira pessoa com quem você cruzar o olhar será seu par", formam-se duplas. Essas duplas passam a caminhar lado a lado, buscando manter sempre a mesma direção e o mesmo andamento. Ambos os integrantes do par podem propor essas variações, inclusive explorando sons como complemento à brincadeira. Aos poucos, os pares encontram outros, formando quartetos. Dependendo da quantidade de jogadores, podem-se formar octetos, ou dois grandes grupos, até todos os jogadores serem reunidos em um mesmo coro. A partir dos quartetos propõese que os participantes prestem atenção aos desenhos que estabelecem no espaço: linhas, círculos, quadrados, triângulos. Ciente do desenho que inscreve no espaço, cada grupo ou o grande grupo escolhe uma forma geométrica na qual permanecerá percorrendo todo o espaço. Uma forma geométrica bastante interessante e recorrente nos desenhos cênicos de Glauber Rocha é o losango. Essa figura contribui para a visualização de todos os integrantes da coletividade. Outra possibilidade é convidar os jogadores, divididos em subgrupos de quatro pessoas, para se posicionarem em forma de losangos e percorrerem o espaço como um todo, sem deformar as dimensões do losango. Na Hidráulica, esse jogo gerou bastante atenção no grupo, apesar da dificuldade apresentada pelas diversas escadas e desníveis presentes no galpão.

\section{Coro e Corifeu:}

Prática vivenciada nas aulas da professora Ingrid Koudela, como decorrência do jogo "Dar e Tomar", de Viola Spolin (SPOLIN, 2001, A74 - número de ficha do fichário). "Um/Qualquer jogador pode iniciar um movimento. Quando um jogador está em movimento, todos os outros jogadores devem parar (nãomovimento). Qualquer jogador pode movimentar-se a qualquer momento, mas deve parar se outro jogador iniciar o movimento". A professora ressaltava a diferença entre dar e tomar: os jogadores podiam "roubar", no sentido de "tomar" o foco de quem se movimentava ou os jogadores podiam "doar" o foco, esperando que alguém lhe passasse o foco do jogo. Tal jogo pode ser feito somente com movimentações ou associado a um jogo com texto. 
O que nos interessa aqui é o desdobramento que se segue: aquele que detém o foco torna-se o corifeu e os outros jogadores, o coro. Destacado do grupo, o corifeu interage com o coro, que por sua vez responde aos seus estímulos, não copiando-o ou espelhando-o, mas reagindo à forma que o corifeu propôs. É interessante que todos passem pela função do corifeu. Ele pode se destacar, espontaneamente, ou ser destacado pelo coro.

\section{Coro com reverência, deslocamento e grito de guerra:}

Versão de coro apresentada por Marcos Bulhões à Tribo de Teatro Tumutupugá, proveniente do repertório de Augusto Boal.

O grupo é dividido em dois coros. Cada coro escolhe um corifeu para iniciar o jogo, sendo que essa função será revezada por todos os integrantes do coro.

O corifeu A propõe uma reverência ao coro $B$, sendo espelhado imediatamente pelo coro A. O corifeu do time B responde ao time A com outra reverência, sendo copiado, de imediato, pelo coro B. O corifeu A propõe um deslocamento até o centro do espaço, seguido pelo coro referente, ao que o corifeu $B$, seguido por seu respectivo coro, responde igualmente com um deslocamento. Assim que os dois coros se aproximarem, o corifeu $A$ propõe um grito de guerra e é seguido pelo coro $A$. O corifeu $B$, juntamente com seu coro, responde, do mesmo modo, apresentando seu próprio grito de guerra. Ao final, alterna-se a função do corifeu, rapidamente.

Toda a movimentação do jogo é improvisada pelo jogador que atua como corifeu e espelhada pelo coro correspondente. O jogo desenvolve a escuta e o controle da ansiedade, uma vez que os corifeus tendem a se antecipar ao coro do lado oposto. Por exemplo, antes que o coro $A$ tenha copiado a reverência do corifeu $A$, o corifeu $B$ já responde com sua reverência. $A$ ansiedade aumenta ainda mais com a aproximação do grito de guerra, a tendência dos corifeus é de ignorarem os coros opostos, quando não ignoram o próprio coro.

Em segundo momento, desenvolvi o jogo, sugerindo que os jogadores investigassem movimentos circulares e contínuos para fazerem as reverências e movimentos retos e diretos para os gritos de guerra. Considero importante a diferenciação da qualidade dos movimentos, pois assim se um 
grupo fizer uma reverência mais forte que o grito de guerra, terá realizado uma escolha e não será confundido com um coro que não se sustenta.

Exercício do guerreiro. [...] em seguida foi pedido aos alunos que andassem pelo espaço da sala procurando ocupá-lo de forma equilibrada. Neste meio tempo um aluno deve lançar seu nome no espaço e quando isso acontecer, todos correm em sua direção, colocando-se todo o grupo ao seu redor, sem que ninguém possa tocá-lo. O aluno colocado no centro da roda deve então esperar uma fração de segundo, até perceber que todos os colegas já se aproximaram e depois dizer o nome novamente. Em seguida, após uma nova fração de silêncio, todos repetem em voz alta, sem gritar, o nome do colega [...](SOARES, 2003, p. 60, grifo meu)

\section{Coro do guerreiro}

Jogo desenvolvido a partir de descrição de jogo dramático de Jean-Pierre Ryngaert, realizada por Carmela C. Soares.

Essa estrutura de jogo pode ser utilizada em diversas situações. Como descrito acima, para apresentar os jogadores e uns aprenderem os nomes dos outros. Ou ainda, em situações de decisão ou avaliação.

Os contornos do velódromo impulsionaram a elaboração do momento de retomada sintética do espaço, na sala branca. Para trazer para os jogadores as sensações e impressões registradas no Velódromo, propôs-se que os jogadores traçassem trajetórias circulares. Para trazer as sensações da Hidráulica foram propostas trajetórias retas e paralelas às paredes, evitandose diagonais. Em seguida, cada integrante do grupo chamava seu próprio nome, ao que os demais jogadores respondiam formando um círculo ao seu redor. O jogador do centro da roda propõe um movimento síntese do espaço e uma palavra ou frase, descrevendo o espaço. Por fim, todos repetem a seqüência de movimentos e frases descritivas, atentos ao discurso criado pelo grupo 23 .

\footnotetext{
${ }^{23}$ As impressões recolhidas sobre o Velódromo foram: "grande", "sinuoso", "Tem uma quadra no meio e uma meia lua no fosso", "dá pra ver o céu", "muitos degraus", "aberto", "amarelo", "vertical", "oco". E sobre a Hidráulica: "canos", "compartimentos", "planos", "máquinas", "novo \& antigo", "multifacetado", "verde e marrom", "muito", "vidros", "água".
} 


\section{ANEXO II}

1. Fotos do Biênio

2. Fotos da Faculdade de Arquitetura e Urbanismo

3. Fotos do Velódromo

(todas as fotos de Renata Velguim)

4. Termo de compromisso destinado aos espectadores de ISAURA S/A + 1 Experimento Hidráulico 


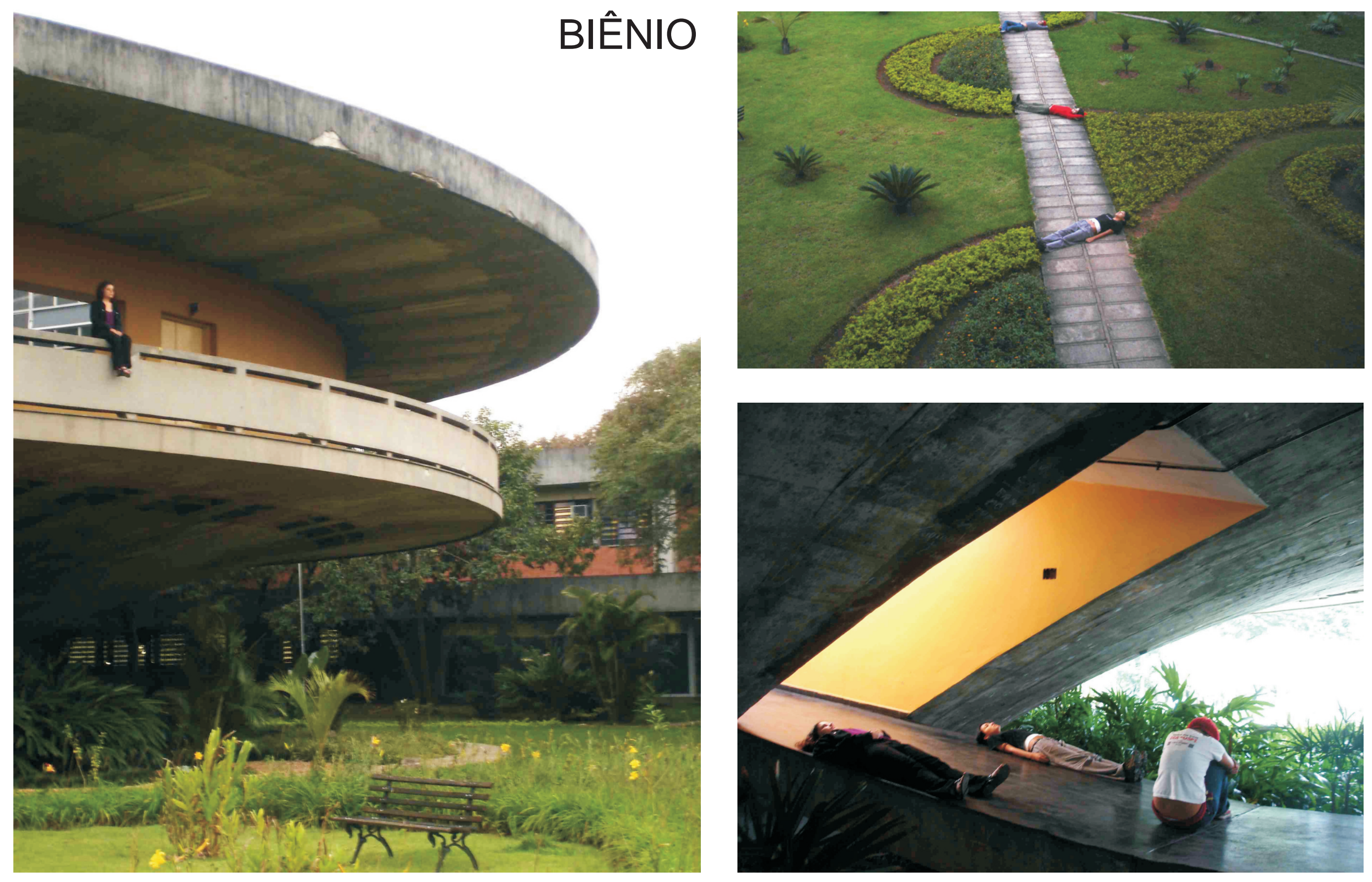



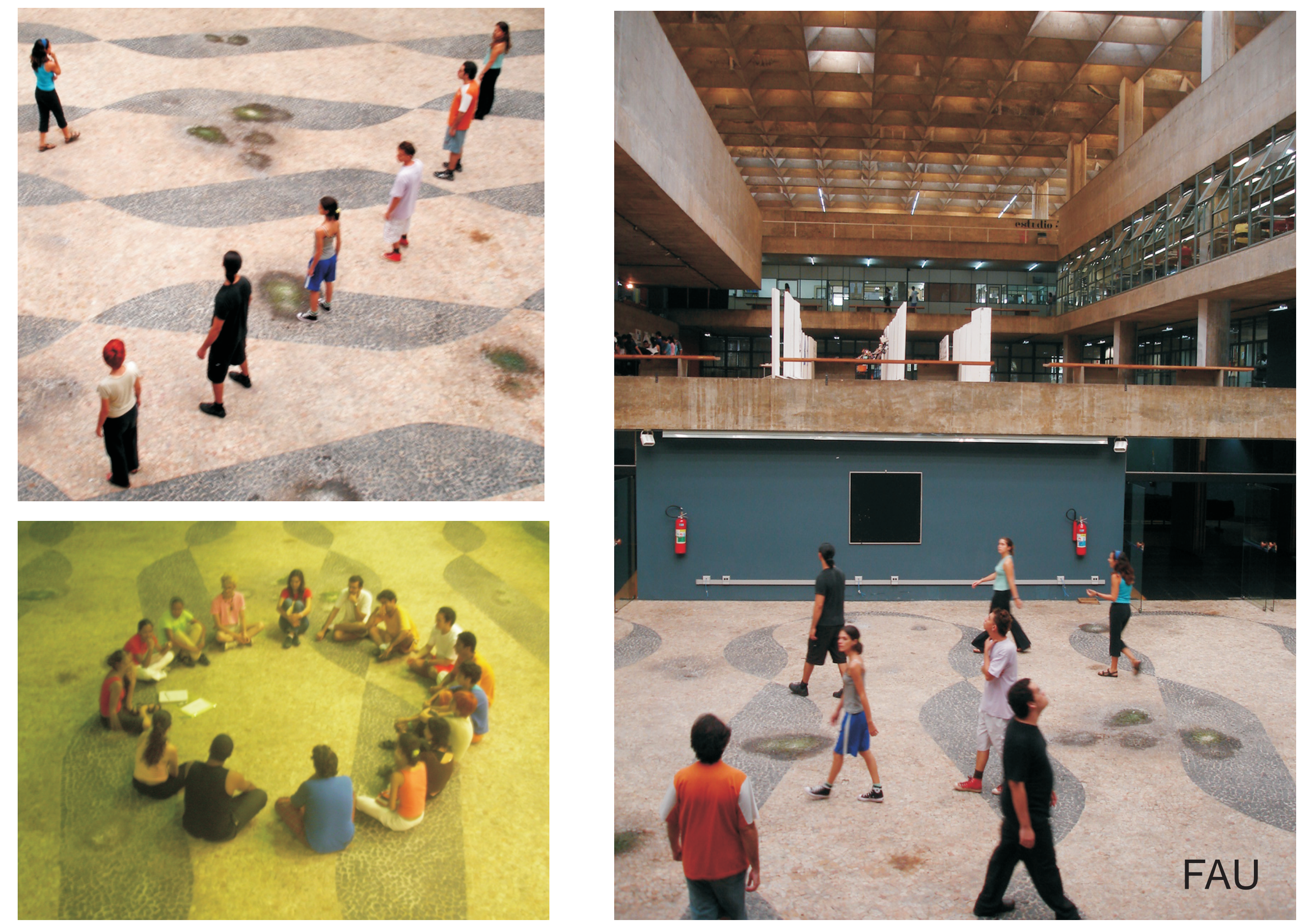


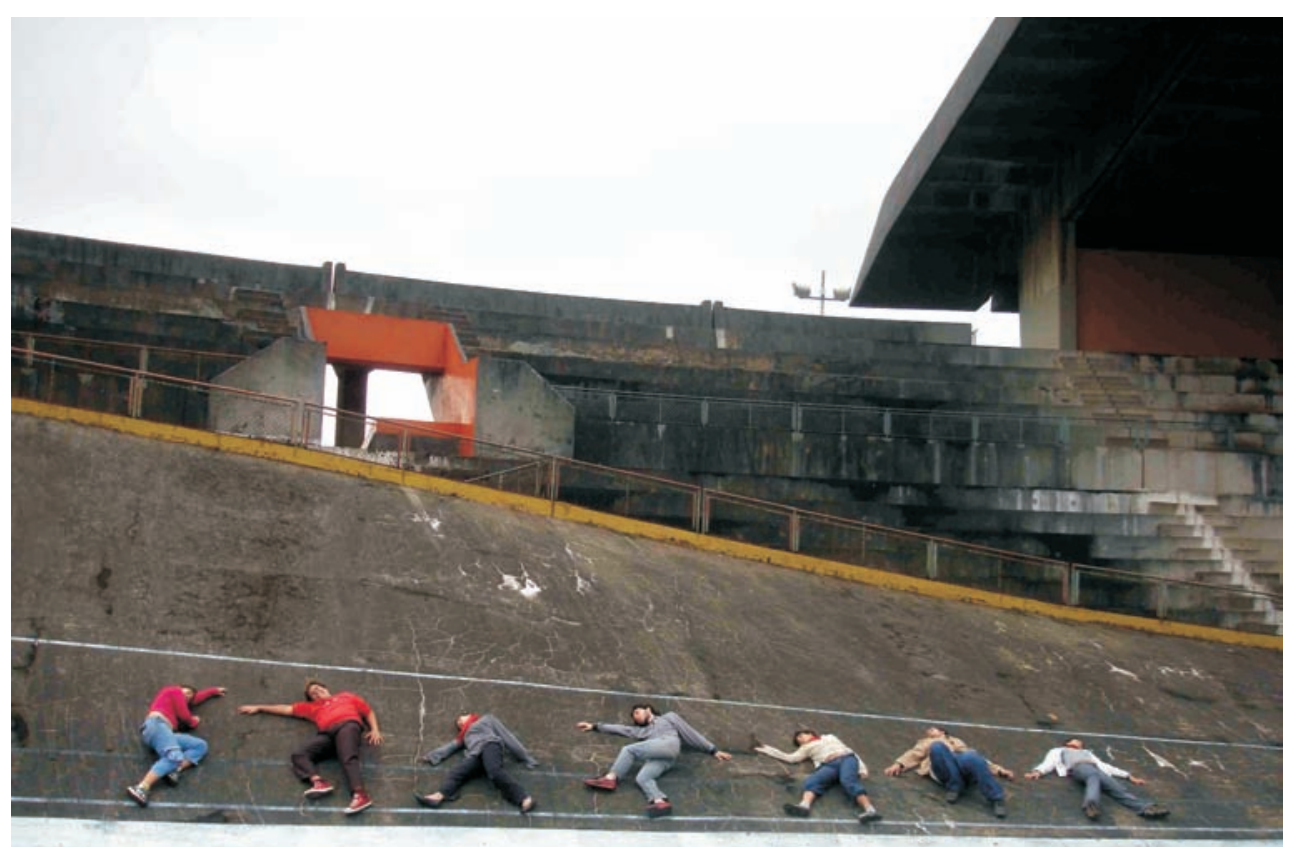

\section{VELÓDROMO}
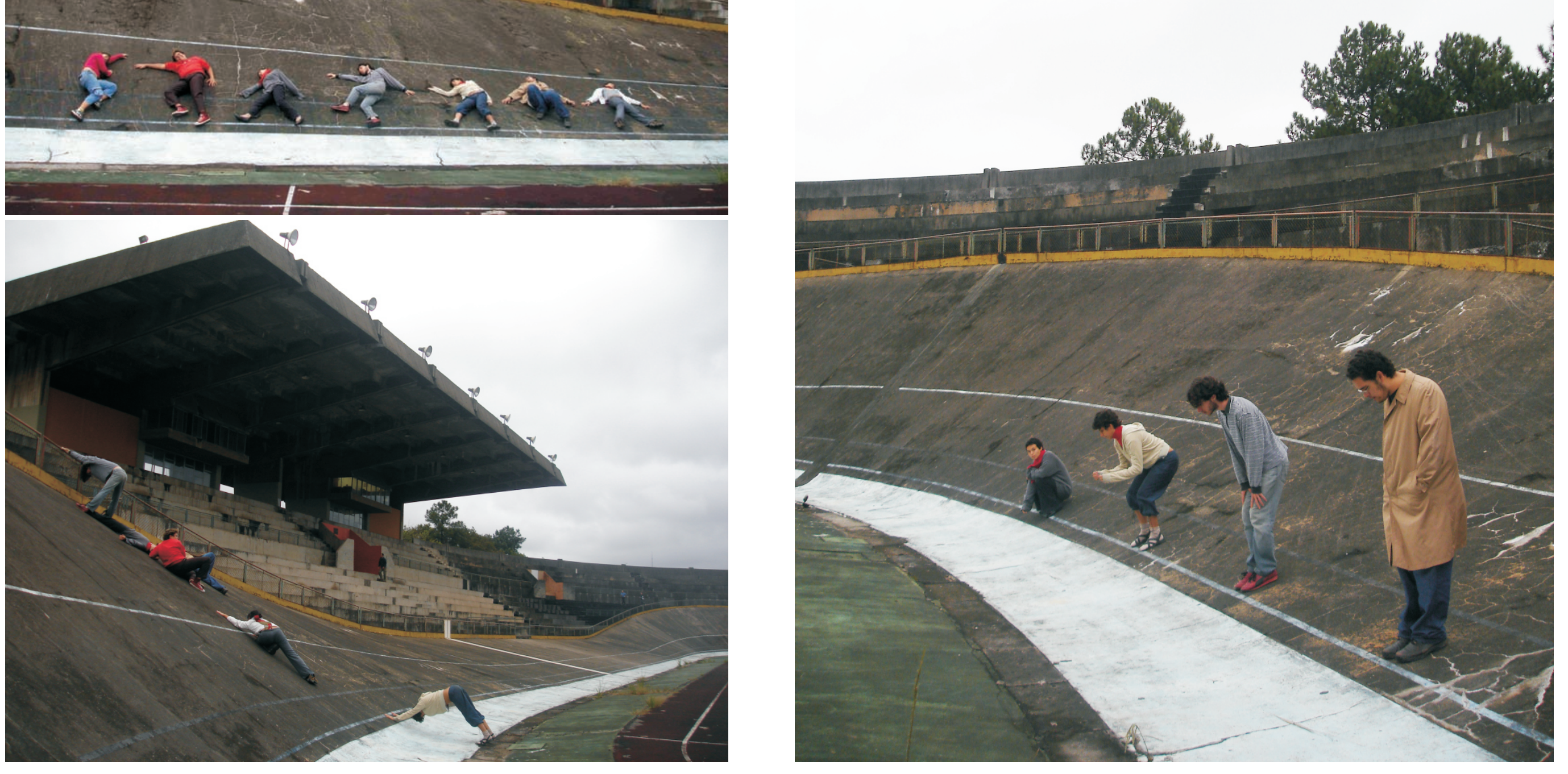


\section{Capítulo 3: Escrever a cena teatral com imagens}

"Hoje atingi o reino das imagens, o reino da despalavra.

Daqui vem que todas as coisas podem ter qualidades humanas.

(...) Daqui vem que os poetas devem aumentar o mundo com suas metáforas.

(...) Daqui vem que os poetas podem compreender o mundo sem conceitos.

Que os poetas podem refazer o mundo por imagens, por eflúvios, por afeto."

Manoel de Barros

Pretende-se nesse capítulo analisar os caminhos propostos para dotar a cena teatral de movimento. Como apresentado no capítulo anterior, partimos de imagens estáticas, fotografias, para a escritura da cena teatral. Trataremos, portanto, de imagens em movimento. Para isso, selecionamos e desenvolvemos modalidades de jogo que envolvem as categorias Espaço, Corpo e Tempo, os quais serão apresentados como partes integrantes da Coleção de Jogos do Olhar. A composição de imagens-movimento depende de corpos disponíveis e atentos aos demais componentes da cena. Por isso apresentaremos versões dos exercícios propostos por mais uma interlocutora (além de Klauss Vianna) na apropriação do corpo no espaço: Anne Bogart. Nessa etapa, estabeleceremos distinções entre o trabalho desenvolvido na Sala Branca e no espaço da encenação, ressaltando a relevância da repetição de certas propostas, com o objetivo de criar uma rotina.

O treinamento físico-vocal desenvolvido em sala de aula e nos ensaios necessitava de continuidade mesmo durante as apresentações do experimento cênico. Assim sendo, refletiremos sobre a função do aquecimento do Coletivo ao longo do processo criativo, no que se refere ao seu caráter de formação e de ritual de chegada. Tanto no caso de ensaios quanto nas apresentações, o aquecimento serve para proporcionar uma mudança de estado. O corpo que chega da rua, carregado de informações precisa se reconectar com o espaço cênico, com os outros jogadores e consigo mesmo. A criação de uma rotina de trabalho garante a qualidade técnica ao mesmo tempo em que propõe esse ritual de chegada. Assim como os pequenos rituais cotidianos (como por exemplo, aqueles realizados antes de dormir), o corpo identifica os rituais de preparação para a entrada em cena. Instaurando esse ritual de chegada 
coletivo, convidamos todos os jogadores para se prepararem juntos, buscando uma presença cênica, diferente de uma presença cotidiana.

Outra questão merece atenção: quais os estímulos para a movimentação dos corpos presentes nas imagens? Além do referido treinamento, voltamos aos filmes, utilizando-os como modelos de ação e estoque de imagens. Nesse momento da pesquisa, debruçamo-nos sobre o estudo do elemento Tempo na constituição das cenas cinematográficas e teatrais. Alguns autores foram consultados e nos guiaram na configuração de jogos e na conseqüente elaboração teórica desenvolvida a seguir. Entretanto, vale adiantar que esse elemento contribuiu em apontamentos parciais, referentes aos movimentos, deslocamentos e ações físicas executadas pelos atores; e totais, referentes à composição da encenação como um todo. Esse fator nos levou mais uma vez à problematização do espaço destinado ao público, especificamente ao trajeto percorrido por ele durante a encenação.

E por último, seguindo o modelo utilizado nos demais capítulos, abordaremos as influências das escolhas realizadas para o processo criativo na configuração do Coletivo de artistas criadores. Tratar do componente Tempo tocou de forma contundente os integrantes do Coletivo, proporcionando muitas reflexões e questionamentos sobre os caminhos trilhados e as opções que acabariam determinando as características desse conjunto de artistas e da encenação à qual se chegou.

\section{Uma dramaturgia para um teatro de imagens}

“Imagens não passam de incontinências do visual." Jorge Luis Borges

Para abordar a dramaturgia de um teatro composto a partir de imagens, iniciamos o tratamento da dramaturgia, ou seja, da leitura das cenas, antes mesmo da inserção de palavras na composição. Excluindo o texto, procuramos ler a sobreposição de múltiplas informações provenientes do espaço (diferente do edifício teatral), dos corpos, dos sons e das músicas inseridas na encenação. Ao optar por um tipo de construção de cena não derivada do texto, aproximamo-nos de uma visão cenocentrista da encenação em oposição a uma visão textocentrista. 
Tal posição radical nega qualquer ligação de causa e efeito entre o texto e a cena, atribuindo à encenação o poder de decidir soberanamente suas escolhas estéticas. $E$, de fato, é assim que procedem numerosos encenadores, de Wilson a Grüber, ou de Mesguich a Heiner Müller. Eles preparam texto, música, cenografia, atuação de maneira autônoma e efetuam a 'mixagem' dessas diferentes pistas apenas no final do percurso, quando se monta um filme. Nesses exemplos, o texto não se beneficia mais de um estatuto de anterioridade ou de exclusividade: é apenas um dos materiais de representação e não centraliza nem organiza os elementos não verbais. (PAVIS, 2005, p. 191)

Não pretendemos, nesse momento, entrar na discussão sobre o papel do texto dentro da encenação; essa será uma tarefa atribuída ao próximo capítulo. A citação acima serve, no entanto, para salientar a autonomia dos demais elementos da cena. Vale acrescentar aqui a reflexão acerca do conceito de teatralidade desenvolvida por alguns teóricos. Josette Féral, nos diversos exemplos que selecionou e discutiu em texto escrito em 1988, entende a teatralidade como alteridade - a visão do outro. Patrice Pavis considera a teatralidade outro termo para encenação e Roland Barthes a vê como o teatro menos o texto. Para Hans-Thies Lehmann é a configuração cênica do teatro. Já o professor Jacó Guinsburg sintetizou o conceito de teatralidade como a qualidade do teatro. Apesar de seus numerosos aspectos, a teatralidade pode ser compreendida como a materialidade cênica, tudo o que se apresenta em cena, visual e auditivamente, sem excluir elementos que eventualmente falem aos demais sentidos (olfato e tato). A busca desses autores por conceitualizar teatralidade é bastante pertinente em um tempo de crise do drama e da representação.

O que parece necessário para desenvolver esse estudo é separar o momento da representação da vida corrente. Ou seja, os recortes efetuados nessa pesquisa referem-se a experimentos assumidamente cênicos, não se trata de intervenções no cotidiano que provocam dubiedade no espectador. $O$ pacto teatral é instaurado, há horário e local pré-estabelecidos para o encontro do público com a cena. Ela não invade seu cotidiano, não o surpreende, a não ser pelo deslocamento espacial, pois se trata de um teatro que acontece fora do edifício tradicional. Talvez nos momentos dos ensaios, da preparação da 
encenação, possa ter havido alguma confusão com a realidade, mas nosso objetivo sempre foi deixar claro que se trata de um evento artístico. Por isso resolvemos investigar se uma encenação pós-dramática pode ser considerada uma narrativa, segundo o conceito desenvolvido por Christian Metz.

Segundo o autor, uma narrativa é uma seqüência temporal, mais ou menos cronológica de acontecimentos. Seqüência temporal por possuir início e fim demarcados, cujos limites a distinguem do resto do mundo, da vida "real". Mais ou menos cronológica para evidenciar que os acontecimentos podem ser organizados de forma linear ou descontínua. Metz afirma que por se tratar de seqüência fechada, toda narração é um discurso, apesar de a recíproca não ser verdadeira. E acrescenta que a narração é duas vezes temporal, pois um discurso é necessariamente proferido por alguém, portanto há o tempo do enunciado (da estória que se conta) e o tempo da enunciação (a "escritura" da cena). Para concluir, aponta que a coisa-narrada deve ser irrealizada, ou seja, um acontecimento deve estar de algum modo encerrado para ser narrado. $O$ autor separa o real do realismo, uma vez que o realismo diz respeito à organização do conteúdo e a realidade pressupõe a presença, para a qual é indispensável a concomitância do espaço e do tempo.

O espectador percebe imagens que foram visivelmente escolhidas (poderiam ter sido outras) que foram visivelmente ordenadas (sua ordem poderia ter sido outra): ele folheia de certo modo um álbum de imagens impostas, e não é ele quem vira as páginas, mas forçosamente algum 'mestre de cerimônia', algum 'grão-mestre das imagens' que (antes de ser identificado como autor, caso se tratar de um filme de autor, e nos outros casos na ausência de qualquer autor) é sempre em primeiro lugar o próprio filme enquanto objeto lingüístico (já que o espectador sabe sempre que é um filme que ele está vendo). (METZ, 2004, p. 34)

O autor citado utiliza durante toda a elaboração do seu conceito o exemplo da narração cinematográfica, especificamente relativa aos filmes narrativo-dramáticos, recorte coincidente com o nosso. Ainda que complexo, seu estudo colaborou para a investigação desse conceito de narração à luz do teatro tratado aqui. As constatações de Metz iluminaram nossa percepção, 
ajudando-nos a afastar os objetos de estudo do produto cênico resultante dessa pesquisa.

Quando o autor assume que a narração é seqüência duplamente temporal, precisamos ponderar sobre o nosso processo de trabalho, uma vez que a encenação realizada como prática dessa pesquisa não contava uma estória, apenas fazia alusões a possíveis estórias, temas ou associações. Portanto, o tempo do enunciado não existe previamente no caso de uma estrutura fragmentada, de uma colagem de espaços-tempos divergentes. Esse tempo poderia existir caso contássemos uma estória, mesmo de forma não linear, o que não ocorre em ISAURA S/A. Nessa encenação, experimentação prática vinculada a essa pesquisa, não há construção de uma fábula; as pequenas estórias sugeridas não convergem para um desfecho que as contextualize, nem encontram uma explicação em um tema central discutido. $O$ que existe é a construção de um discurso que cria ilusões de fios narrativos, um panorama de imagens, respostas soltas aos estímulos provenientes do espaço e do diálogo com os filmes pesquisados. O tempo da enunciação, todavia, é sempre existente, pois se refere ao tempo de permanência do espectador em contato com a obra artística, consciente de que não se trata da vida real. Contudo, podemos afirmar que, nesse caso, o tempo do enunciado e o tempo da enunciação não podem ser separados.

A encenação formulada nesse estudo consiste em um discurso fechado que realiza (e não irrealiza, como propõe o autor) uma seqüência temporal de acontecimentos. Não podemos afirmar que irrealiza, pois a presença dos atores no aqui-agora da cena é uma especificidade teatral. Logo, o acontecimento realiza-se na presença do público, no mesmo espaço e tempo no qual se encontra o espectador. O tempo da apresentação da peça e de sua recepção é compartilhado, é também tempo de vida de ambos, artistas e espectadores. Talvez pelo mesmo motivo se possa afirmar que não há narração, uma vez que o evento não está encerrado, mas acontecerá ao vivo. Por outro lado, talvez o fato de se tratar de um acontecimento conhecido, ensaiado e preparado anteriormente e não improvisado, torne-o relativamente "encerrado". Nesse caso, a incerteza é aquela inerente a todo e qualquer espetáculo vivo, se considerarmos que a cada dia vivencia-se um 
acontecimento diferente, ou se ao contrário, constatarmos que se trata de um acontecimento encerrado porque foi planejado e ensaiado anteriormente. Poderíamos então dizer que a narração teatral seria um "discurso fechado que irrealiza uma seqüência temporal de acontecimentos" (Ibidem, p. 42). Mantendo essa incerteza no que diz respeito ao encerramento de uma narração teatral, questiono a pertinência da afirmação de Metz em se tratando da encenação resultante deste estudo, pois percebo que ela coincide com o trecho a seguir:

Cenas sem um índice temporal concreto podem gerar uma
temporalidade flutuante, uma incerteza quanto à sucessão narrativa.
No nível da manifestação teatral chega-se a fenômenos de
temporalidade mais difíceis de apreender. Repetições obsessivas,
aparente inação, inversão de causa e efeito, extremos de
prolongamento ou de aceleração, saltos temporais e surpresas
chocantes podem distorcer a percepção normal do curso do tempo.
Tais recursos se tornam constitutivos no teatro pós-dramático, já que
ele desloca a temática temporal do nível dos significados (os
processos denotados pelos recursos cênicos) para o nível dos
significantes (os próprios processos cênicos). (LEHMANN, 2007, p. 294)

Em suma, mesmo não partindo de uma estória, nem a tendo como ponto de chegada, uma encenação composta de fragmentos é uma seqüência fechada, portanto é um discurso, mas não pode ser necessariamente considerada uma narração. Uma obra cheia de tensões internas é um discurso projetado por alguém, ainda que suas partes não se encaixem e seus sentidos sejam sugeridos pelos descompassos provocados pela justaposição dessas partes. Existe uma responsabilidade sobre essas escolhas, pois os elementos da cena não foram colocados ao acaso para se confrontarem no momento da experimentação pública. Há uma responsabilidade pela junção das partes no espaço-tempo da ficção, cuja natureza está garantida por sua separação da realidade.

Um exemplo citado em aula pelo professor Ismail Xavier ajuda a esclarecer a questão. Imagens filmadas ao acaso por uma câmera de vigilância podem ser consideradas uma narrativa? Não. No entanto, se alguém escolher 
um ponto qualquer, demarcado por algum passante ou algum acontecimento, e defini-lo como o começo, e em seguida, escolher outro ponto para igualmente demarcar como sendo o final, chega-se a uma narrativa. Na ocasião, não tive a oportunidade de realizar a seguinte pergunta: $E$ se recortarmos e colarmos aleatoriamente uma série de inícios e fins, demarcando o início e o final geral, chegaremos a uma narrativa? De acordo com a definição de narrativa apresentada por Christian Metz, acredito que não. Podemos chegar a um discurso e não a uma narrativa.

A cena deve ser relativizada; é o contrário da cena absoluta (dramática) que possui unidade de tempo e lugar. Poderíamos citar como exemplo cenas do filme "O Bandido da Luz Vermelha", de Rogério Sganzerla, em que identificamos com freqüência descontinuidades espaciais e temporais, contra o princípio de seqüência de presentes absolutos. Esse filme é um exemplo de construção descontínua, não-linear. No entanto, não podemos afirmar que não se trate de uma narrativa, pois seus fragmentos colecionados contam a estória do Bandido da Luz Vermelha, de seu nascimento até sua morte. O exemplo, contudo, explicita a presença da montagem, ou mixagem, cuja apresentação revela ao espectador que as imagens e sons foram organizados segundo uma lógica própria.

A observação das amostras de cenas retiradas dos filmes estudados nos ajudou na discriminação de alguns procedimentos fílmicos relativos à categoria Tempo. A estrutura da composição fílmica depende da articulação das imagens no tempo, uma vez que a narração cinematográfica acontece através das imagens. Seguindo o modelo cinematográfico, propusemos movimentos para as imagens inicialmente estáticas, compostas como fotografias no recorte espacial. Podemos destacar os seguintes procedimentos: ordem, duração, repetição, justaposição, simultaneidade, paralelismo e paralisação dos planos.

Optamos por não mencionar aqui os flashbacks, uma vez que eles podem ser identificados em situações em que uma estória é contada, indicando uma construção formal, uma estruturação de acontecimentos apresentados fora da ordem cronológica. No caso do teatro aqui experimentado, ao retomar uma imagem ou cena não se trata de flashback, apenas de repetição. A combinação das cenas serve justamente para desestruturar, desarticular a possibilidade de 
configuração da fábula. Nesse estudo há uma coleção de instantes fragmentados e aleatórios, construídos a partir da fricção entre imagens produzidas na arquitetura da Hidráulica e a interferência dos modelos fílmicos.

Exploramos a duração, a repetição, a imobilização, a justaposição, a simultaneidade e o paralelismo como formas de tratamento do tempo. Lehmann qualifica-as como técnicas teatrais de distorção do tempo (LEHMANN, 2007, p. 306), pois evidenciam a existência de uma montagem, em detrimento da instauração da unidade temporal. A idéia de manipular o tempo como elemento constitutivo da cena reforça a presença do tempo para além do tempo "percebido" da encenação. Exemplo disso são as encenações de Bob Wilson, em que a dilatação do tempo relativiza cada uma das cenas, dotando-as de unidade independente do todo. As técnicas de deformação do tempo revelam sua presença e fazem a construção temporal saltar aos olhos dos espectadores, tornando explícita a presença do montador (alguém que articula os elementos da cena). A montagem contraria o princípio da seqüência de presentes absolutos, típico da construção dramática, afirmando a descontinuidade temporal da obra.

A duração e a repetição podem ser tratadas em duas esferas: nos movimentos que se configuram como ações físicas e na cena como um todo, cuja duração e repetição podem ser definidas pela significação percebida. Esses dois tratamentos serão desenvolvidos posteriormente nos itens que se referem aos filmes como modelo de ação e à composição do roteiro da encenação. A imobilização pode ser associada ao princípio gerador de todas as cenas criadas no processo criativo de ISAURA S/A, uma vez que partimos da composição de fotografias, imóveis por natureza. Os mecanismos de duração (principalmente aquelas muito lentas) e repetição causam ilusão de imobilidade e depõem contra o aceleramento do tempo comum na experiência cotidiana. Indo na contramão da velocidade da vida, as cenas que se utilizam desses recursos convidam o espectador a outro tempo do olhar, à contemplação. De acordo com Lehmann esses tratamentos do tempo contribuem para impedir a primazia da fábula da construção da encenação. (Ibidem, p. 310, grifo do autor) 
Assim como na duração, na repetição há uma cristalização do tempo, uma compressão e uma negação mais ou menos sutis do decorrer do tempo. É certo que o ritmo, a melodia, a estrutura visual, a retórica e a prosódia desde sempre empregaram a repetição - não há nenhum ritmo musical, nenhuma composição de imagens, nenhuma retórica eficaz, nenhuma poesia, em suma, nenhuma forma estética sem uma repetição utilizada intencionalmente. [...] se antes ela servia para a estruturação, para a construção de uma forma, aqui ela serve justamente para a desestruturação e desconstrução da fábula, do significado e da totalidade formal.

A justaposição, do mesmo modo, articula seqüências de imagens ou cenas independentes da relação de causa e efeito entre os acontecimentos. Configura-se como uma maneira de contar não dramática, sem o encadeamento de momentos significativos um em relação ao outro. Voltaremos a essa questão no item dedicado ao estudo da composição do roteiro.

A simultaneidade é distinta do paralelismo, pois, na primeira, duas ações são simultâneas, competindo pelo foco de atenção da platéia. No caso de nossa exploração cênica, consideramos simultâneas as cenas que ocorriam ao mesmo tempo, obrigando o público a escolher entre dois ou mais pontos de observação. Essa construção é arriscada, pois parte do público pode perder algumas cenas, caso fique preso a uma seqüência ou cena específica. $O$ recurso da simultaneidade foi aplicado no início da encenação de maneira mais sutil, uma vez que um dos personagens induzia o público a percorrer todas as cenas. No entanto, todas as cenas consideradas simultâneas estavam instaladas no espaço, de modo que mesmo sem assisti-las diretamente, os sons e vozes provenientes delas eram ouvidos pelo público. Houve outro caso de simultaneidade mais explícita, na cena que denominamos "caos", pois nela o público estava posicionado em espaço restrito e era, literalmente, cercado por cenas que surgiam sobrepondo-se umas às outras. Nesse exemplo, no qual o público era pulverizado por cenas de todos os lados, tínhamos o objetivo de sintetizar a experiência vivenciada até aquele momento, citando várias seqüências já apresentadas e confundindo deliberadamente a atenção dos espectadores. 
Já no paralelismo, uma ação ou cena é interrompida para que outra seja observada pela platéia. Podemos dizer que o paralelismo está mais próximo da justaposição do que da simultaneidade, com a diferença que também joga com a repetição. Logo, quando as cenas são simultâneas, os espectadores escolhem qual cena observar; quando elas são paralelas, a composição guia o olhar do espectador para observar uma cena ou outra.

Os procedimentos elencados acima se aplicavam tanto à composição dos planos (fotografias que ganhavam movimento) quanto à estruturação dos mesmos ao longo da narrativa. A seguir observaremos a aplicação desses diferentes tratamentos do tempo na composição das cenas (imagens que foram dotadas de movimento) e a composição do roteiro como um todo - o macrocosmo da encenação.

\section{O olhar de Klauss Vianna para Anne Bogart: do treinamento ao} aquecimento

Apresentaremos a seguir as fontes referentes ao estudo do corpo, seja ao desenvolver parâmetros para a observação dos corpos nas cenas de cinema, seja ao disponibilizar o corpo para a movimentação dentro da cena teatral. Além da Técnica Klauss Vianna ${ }^{23}$, buscamos o conceito de Viewpoints desenvolvido por Anne Bogart ${ }^{24}$. Viewpoints são princípios de movimento que constituem uma linguagem para se falar do que acontece no espaço cênico, utilizados para o treinamento de performers para a criação coletiva. A autora separa seus Viewpoints em dois grupos, um relativo ao tempo (andamento, duração, resposta kinestésica e repetição) e outro referente ao espaço (forma, gesto, arquitetura, relação com o espaço e topografia), somando um total de nove Viewpoints. Utilizamos nesse estudo os Viewpoints relacionados ao tempo, pois no momento em que conhecemos os Viewpoints todo o trabalho voltado para o estudo do espaço já havia sido realizado. Elaboramos versões de exercícios descritos por Anne Bogart em The Viewpoints Book: A Practical Guide to Viewpoints and Compositions e as propusemos ao Coletivo. Digo

\footnotetext{
${ }^{23}$ As referências à Técnica Klauss Vianna são decorrentes de minha experiência com Lu Carion no OBARA - Grupo de Pesquisa e Criação em Teatro-Dança, portanto trata-se do meu olhar sobre essa técnica.

${ }^{24}$ Segundo recomendação da professora Sílvia Fernandes durante o Exame de Qualificação. 108
} 
versões, pois não os pratiquei, apenas os sugeri a partir da interpretação de uma leitura particular.

Anne Bogart propõe cinco imagens para reforçar a presença corporal, apresentadas abaixo a partir do filtro da Técnica Klauss Vianna. Bogart trabalha excessivamente com o imaginário do ator, ao passo que Klauss propõe formas mais concretas para lidar com o corpo, sem basear-se em imagens. Portanto, a leitura que fazemos elimina a maior parte das imagens propostas por ela.

-Pés muito bem apoiados no chão, como raízes, seguidos de pernas fortes. Para isso sugere que os exercícios sejam realizados com pés descalços (só foi possível na sala branca, jamais na Hidráulica);

-Braços soltos ao longo do corpo;

- Cabeça suspensa por um fio até o teto;

- Olhar suave (soft focus), sem tensão, recebendo as informações do espaço;

- Coração aberto para vivenciar as propostas, o que significa também peito literalmente aberto.

Apesar de Anne Bogart apresentar tais imagens iniciando sempre pelo verbo "Imagine", transformamos essas imagens em indicações mais técnicas, de acordo com aquelas adotadas no estudo da Técnica Klauss Vianna. Tanto Anne Bogart quanto Klauss Vianna se referem à mesma questão: a atenção ao momento presente através da percepção de partes do corpo. No entanto, o segundo subtrai imagens que afastem o indivíduo da percepção sensorial de seu próprio corpo.

A combinação da Técnica Klauss Vianna e dos exercícios de Viewpoints desenvolvidos por Anne Bogart constituíram um rico repertório para o treinamento físico-vocal proposto ao Coletivo. Os jogos de atenção de Anne Bogart surgiram como uma sucessão dos exercícios propostos por Sotigui ("roda de palmas" e "caminha e parada"). Experimentamos combinar exercícios de Sotigui com Bogart, mas constatamos que essa combinação gerou apenas dificuldades excessivas, impondo mais desafios e mera demonstração de habilidades. Ambos os exercícios têm suas finalidades e interesses peculiares 
e podem ser propostos em momentos distintos, como variações de jogos de atenção em círculo.

É importante efetuar uma distinção entre dois enfoques do trabalho corporal: o treinamento de base desenvolvido na Sala Branca (sala de ensaios) e a transformação gradual desse treinamento em aquecimento utilizado na locação. Os ensaios na Sala Branca foram ao mesmo tempo uma opção e uma necessidade. Optar por ensaiar na sala foi importante, pois a atenção dos jogadores voltava-se para a percepção de seus corpos e das relações entre eles. O espaço era um continente com poucas informações, um tubo de ensaio. Já nas arquiteturas experimentadas e, posteriormente, na locação escolhida, o espaço era carregado de informações, demandando dos jogadores atenção diferente. O treinamento na locação também exigia algumas adaptações em função das características do espaço. No caso da Hidráulica, o espaço era bem maior que a sala de ensaios, não tinha chão apropriado para o trabalho corporal e foi preciso encontrar o melhor local dentro do galpão para o grupo realizar seus aquecimentos.

Durante o período de ensaios, ficamos dois meses fora da Hidráulica. Por problemas de re-estruturação interna do Centro Tecnológico, só nos restava ensaiar na Sala Branca. Por esse motivo afirmei anteriormente a necessidade de trabalhar nesse espaço. No entanto, a vivência nessa sala possibilitou o refinamento do estudo do Tempo, tanto no treinamento físico-vocal, quanto nas cenas.

Se observarmos os viewpoints agrupados por Anne Bogart na categoria tempo (andamento, duração, repetição e resposta kinestésica), poderemos notar que eles coincidem com as propostas de estudo e apropriação do movimento propostos na Técnica Klauss Vianna, com exceção da resposta kinestésica (de certo modo também desenvolvida, mas não com esse nome). Desse modo, as versões dos exercícios propostos por Anne Bogart (descritos na Coleção de Jogos do Olhar), vivenciados inicialmente na Sala Branca, referem-se à resposta kinestésica, escuta e prontidão para responder a estímulos externos.

$\mathrm{Na}$ Técnica Klauss Vianna, a variação temporal era um dado relevante nos exercícios de apropriação de partituras físicas. Entendemos por partitura 110 
uma seqüência de movimentos envolvendo determinadas articulações e passível de modulações na direção (espacial), no esforço corporal (tônus) e no tempo (do muito lento ao muito rápido). São recorrentes também os exercícios de mudança de níveis (do alto ao baixo e vice-versa) em diferentes tempos (andamentos): 16, 8, 4 e 2 tempos. Tais exercícios colaboram na exploração da partitura que pode ser executada com os dois lados do corpo, em níveis diferentes, em outras direções e ainda rápida ou lentamente. Todas essas variações servem para o real aprendizado da seqüência de movimentos, que depois de ser experimentada em todas as suas "tonalidades", torna-se um vocabulário para o jogo e não uma amarra, uma limitação. Semelhante às regras do jogo, a partitura não limita, apenas delimita a esfera de possibilidades de movimentação durante um improviso.

$$
\text { (protocolo de Paula Bellaguarda) }
$$

"A partitura ao contrário. A partitura em outras direções. A partitura destrinchada. A partitura começou a existir para mim a partir do diálogo com as novas partituras. [...] Estou entendendo o procedimento. Uma partitura é um lugar de onde se sai e cria justaposições."

Manoel de Barros escreveu "Repetir, repetir, até ficar diferente. Repetir é um dom do estilo." O poeta traduz com esses versos um princípio muito caro para a atividade do ator, referente ao tempo: a repetição. Repetir deve adquirir outro sentido para os atores: fazer de novo. Há três naturezas de repetição que merecem ser destacadas. A primeira, aproxima o ator da apropriação do material cênico, pois à medida que ele o repete, apodera-se dele, e, de acordo com Manoel de Barros, também transforma o movimento e, por conseqüência a estrutura da cena. A segunda repetição destacada é aquela que se refere à imitação, à apropriação de modelos de ação, que podem ser textos, imagens (fotografias, pinturas, esculturas), músicas e filmes (no nosso caso). Essa repetição pode ser comparada à antropofagia preconizada por Oswald de Andrade. Ao repetir, copiar, apropriar-se de uma ação ou um texto e transportálo para outro contexto, ele(a) é ressignificado(a), adquirindo outro estatuto referente ao novo contexto em que é inserido. Alguns exemplos dessa repetição serão demonstrados no item em que trataremos dos filmes como modelos de ação e estoques de imagem.

Por último, podemos destacar a repetição à qual o ator é submetido a cada apresentação. Como repetir as mesmas cenas a cada dia, sem 
mecanizá-las? Essa é uma questão própria à atividade teatral, cuja resposta configura-se em uma busca constante por perceber pequenas alterações no estado corporal individual e no jogo com o outro, que é sempre diferente. Por esse motivo, diz-se que cada movimento é único, encerra-se em si mesmo. Não há possibilidade de repetição, pois ao fazer de novo, o corpo já está modificado e o movimento será diferente. No item 4 , voltaremos a discutir a repetição de partes como recurso estilístico, ou seja, a repetição de imagens ou cenas na estrutura da encenação.

No que se refere ao quesito tempo, podemos recorrer aos conceitos de duração e andamento, os quais podem ser experimentados de forma semelhante. A duração de um movimento ou cena processa-se num contínuo, podendo variar de curta a longa e o andamento também varia de lento a rápido. Por isso, na apropriação dos movimentos executadas nas posições definidas em cada imagem e nas transições de uma imagem à outra, exploramos muitas variações de duração e andamento. Chegamos à duração das cenas quando definimos os andamentos das ações. Desse modo, o jogador verifica quanto tempo permanece realizando tal ação em determinado andamento e também verifica a possibilidade de aceleração e desaceleração das ações.

(Protocolo de Katia Lazarini)

"O elemento Tempo para a composição da cena. Parece sempre óbvio se falar em andamento, principalmente em dança. Antes do processo Jogos do Olhar, nunca tinha considerado o Tempo como um elemento teatral essencial para a composição cênica."

Alguns exercícios relativos ao tempo, inspirados na técnica do butô, também foram experimentados. Consistiam em estabelecer tempos específicos para os jogadores executarem ações simples como, por exemplo, chegar ao chão em um minuto ou sair do fundo da sala e chegar à frente dela em cinco minutos. Ao lidar com a duração real de uma atividade, o Coletivo percebeu na pele a sensação da passagem do tempo. Na primeira vez que fizemos o exercício dos cinco minutos, a maioria dos jogadores demorou mais tempo para chegar à frente da sala do que os cinco minutos previstos. Isso prova uma atitude ansiosa que reflete os tempos atuais, quando cinco minutos parecem mais tempo do que realmente é. 
(protocolo de Clóvis Lima)

"Quanta impaciência... Cinco minutos que não chegam nunca. Vou na minha ou na velocidade do grupo? Eles parecem estar mais lentos. Acho que não é a proposta, vou na minha. Reparei que quando não ligo muito para o tempo, me atento só à respiração, fico mais tranqüilo, caminho com mais fluidez, sem desequilíbrios e até com uma sensação gostosa.

Depois, senti o cansaço."

A percepção do tempo é relativa, por isso o advento do relógio, objeto de referência para as sociedades que se desconectaram dos eventos da natureza. O teor da proposta do jogo, contada em minutos, já denota hábitos urbanos, de uma era em que o tempo é cronometrado, sem vínculos com a natureza. Não trabalhamos menos nos dias mais curtos do inverno, não nos recolhemos quando chove torrencialmente, nem respeitamos a noite como a hora do descanso. Não há licenças para o homem urbano contemporâneo. Essa divagação é sinal dos tempos. Ela interfere na prática teatral, reflexo de seu tempo, e em certas ocasiões uma cena, um jogo ou improviso podem ser treinados para durar um tempo preciso. Com a ajuda do cronômetro pode-se garantir a duração do evento cênico, dependendo apenas da repetição, do número de vezes em que nos propomos fazer mais uma vez.

Essas propostas colaboraram para a distinção de dois atributos relativos ao tempo: duração e andamento. A duração de cada movimento é o tempo gasto na execução de uma ação ou partitura. $O$ andamento é a velocidade, podendo variar entre lento, moderado e rápido. Por exemplo: quanto tempo alguém permanece realizando determinado movimento em tal andamento? Outra pergunta que ajudava a definir a duração de um movimento (sem ser cronometrado) era: o que fazer enquanto fulano faz tal ação?

$$
\text { (protocolo de Katia Lazarini) }
$$

"Mudar o tempo de realização do movimento é mudar o movimento."

No que diz respeito às cenas, distante do Laboratório de Hidráulica, quando ensaiamos na Sala Branca (sala de ensaios do Departamento de Artes Cênicas) com as informações visuais do espaço eliminadas, foi possível o centramento do foco de atenção no desempenho dos atores. A observação cuidadosa dos movimentos executados em andamentos diferentes possibilitou a compreensão exata, por parte dos atores, das características dos seus movimentos: quais articulações estavam envolvidas, quais os apoios utilizados 
e qual o tônus adequado. Esse período de ensaio na Sala Branca devolveu às cenas uma precisão pouco provável de ser obtida caso não tivéssemos saído da complexidade do espaço da Hidráulica.

(protocolo de Daniel Cordova)

"A Hidráulica não fez falta! Não que ela seja dispensável. Ela não é. Eu sou da opinião que levar o projeto para outro espaço seria iniciar um novo processo, o que não tem coerência. Mesmo assim, nesses primeiros cinco ensaios do ano foi bom poder olhar para as cenas diante de um fundo branco. Foi como colocá-las no microscópio. Pudemos trabalhá-las na minúcia, nos detalhes e preocupamo-nos em resolver, ou propor soluções para problemas que passavam despercebidos, ou que nunca foram encarados. Além disso, o trabalho corporal para mim pareceu aprofundado. Não sei se pela irregularidade que eles acabaram acontecendo no final do ano passado ou pelas faltas ou por qualquer outra razão, eu não havia me sentido seguro sobre o que estávamos trabalhando como no intensivão. Ou vice-versa: a constância de trabalhar dias seguidos traz essa sensação de domínio. Enfim, depois de um dia de trabalho, a continuação já vinha no dia seguinte, ainda estava tudo fresco na cabeça (estou falando dos direcionamentos). E é gostoso se sentir direcionado. Os novos exercícios mostraram também que não é necessário saturar os exercícios antigos para propor algo novo. Eles (os novos exercícios) dão uma arejada no trabalho, além de suas finalidades específicas."

Na Hidráulica, o treinamento corporal adquiriu novas dimensões, uma vez que ele tomava proporções de um aquecimento. É válido salientar que não entendemos o aquecimento como um momento descolado da criação, mas como uma preparação, uma inscrição no corpo das mobilizações que serão requisitadas dele no momento da criação. Vivemos dois momentos distintos de configuração de aquecimentos, um na época dos ensaios abertos, realizados depois de nove meses de processo (sendo seis meses na Hidráulica) e outro na ocasião da temporada da encenação, quatro meses depois (sendo dois meses na Hidráulica).

Já que estamos tratando de questões relativas ao tempo, abro um parêntese para discorrer sobre a importância de se revelar a quantidade de meses dedicados ao processo criativo, e proporcionalmente, o tempo de permanência do Coletivo na locação. Acredito na descrição dos procedimentos adotados e na exposição do tempo de trabalho como convite à análise do processo vivenciado, em detrimento do produto apresentado. Apenas relevando a freqüência das atividades realizadas e o teor do trabalho proposto, disponibilizaremos os conhecimentos construídos no sabor da prática, 
entendendo essa atitude como uma busca por democratizar e desmistificar processos criativos teatrais. O objetivo pedagógico que cerca a pesquisa só parece possível graças à transparência adotada no estudo dos princípios investigados, convidando todos os envolvidos no Coletivo a uma reflexão conjunta sobre os modos de produção da encenação. Tais questões serão retomadas em outros momentos da escrita; agora voltemos às configurações dos aquecimentos coletivos.

Dois pontos eram fundamentais para configuração do aquecimento: realizá-lo coletivamente, como definição de estado corporal comum a todos, e desenvolvê-lo com o objetivo de preparar o corpo e a voz para a cena de forma atenta e consciente às singularidades de cada corpo. $O$ momento do aquecimento compreendia uma entrega, uma passagem do estado "da rua" para um estado de prontidão necessário à cena. Uma boa metáfora seria dizer que passamos de um estado de prosa para um estado de poesia. Esse momento demanda escuta do próprio corpo e do corpo do coletivo, a cada dia diferente e imprevisível, por isso optamos por estabelecer uma seqüência definida de propostas repetidas todos os dias. Ao invés de estancar a escuta ou mecanizar o aquecimento, a repetição da mesma seqüência torna-se uma referência para o grupo perceber com maior facilidade as alterações no corpo dia após dia. Se o aquecimento variasse, seria mais difícil a manutenção do treinamento corporal com o mesmo rigor adotado na sala de ensaio. Ele funciona como uma recuperação da aula, do estudo, da pesquisa, mesmo durante as apresentações, quando os atores tendem a se sentir "prontos". O aquecimento como um ritual diário, garante um mínimo de qualidade técnica, tirando o ator da zona de conforto (sensação de experiência já vivida) e respeitando as variações constantes de nosso corpo: cansaço, humor, hormônios, tristeza, preguiça, etc.

Entre cada articulação existem cápsulas e essas cápsulas contêm um líquido que, conforme o aquecimento, começa a dar elasticidade à musculatura. Daí o valor de um aquecimento bem-feito, profundo e detalhado. (VIANNA, 2005, p. 140)

Outra questão foi levantada: o aquecimento depende ou não de uma condução externa? Durante os ensaios abertos, muitos ajustes técnicos 
dependiam de minha atenção e era difícil me desdobrar para estar junto dos atores no aquecimento. A definição do passo a passo do aquecimento dotou os jogadores de autonomia para se preparem para a cena sem depender de uma condução externa. Juntos, longe dos olhos da encenadora-professora, responsabilizavam-se pela preparação de seus corpos para a cena e foram capazes de problematizar sua pertinência.

(protocolo de Daniel Cordova)

"Quando se consegue realizar um exercício com perfeição é hora de descartá-lo ou a palma do Sotigui e os tempos e contratempos são aquecimentos que devem acontecer sempre? Assim como eu sempre vou me espreguiçar para acordar as partes do corpo, eu sempre vou realizá-los para acordar a escuta, a conexão com os outros e a prontidão?"

Posteriormente, com a proximidade da estréia, lidamos com outra formatação do aquecimento, inserindo e retirando jogos, observando qual a melhor seqüência para esse novo momento. No trecho abaixo, podemos notar o questionamento do jogador sobre sua apropriação do novo aquecimento:

(protocolo do Daniel Cordova)

"O aquecimento está em construção, o que me dá certa insegurança, uma sensação de falta de propriedade, enfim, divagações. Gostaria que ele fosse menor, ou que não dependêssemos tanto da condução para saber o que fazer em seguida. Problema real ou dificuldade em lidar com o novo?"

A vontade de que o Coletivo fosse autônomo e responsável pela preparação de seu corpo e voz norteou a decisão de que o aquecimento fosse realizado sem minha presença e intervenção.

$$
\text { (protocolo de Katia Lazarini) }
$$

"Aquecemos sozinhos. É legal ter uma estrutura de aquecimento, isso traz uma autonomia para o grupo. Todos sabem o que fazer, mesmo na ausência da coordenadora."

Aos poucos, fui percebendo que o aquecimento estava ficando cada vez mais curto, mesmo com a colaboração de Paulina (amiga que participou de parte do processo criativo) e do professor Fábio Cintra na observação do aquecimento, dando retornos e amparando os atores. Após a estréia da encenação, tivemos a oportunidade de refletir sobre a potencialidade do aquecimento como preparador de uma boa apresentação. Diante de toda a inquietação dos jogadores, resolvi conduzir o aquecimento, participando da 
parte inicial, com o objetivo de verificar se o problema era a configuração do aquecimento ou "como" ele estava sendo realizado. Resultado: chegaram à conclusão de que o aquecimento era bom, o problema estava na ausência de uma condução. Não acredito que se possa enunciar uma regra geral segundo a qual um grupo de atores não conseguiria se aquecer coletivamente sem a condução de alguém. Verifiquei sim, que durante um tempo, fizeram isso muito bem. Notei, mais uma vez, o quanto um agrupamento de pessoas investigando o fazer teatral configura uma experiência dinâmica, sem receitas ou regras gerais. $\mathrm{O}$ que vale para um grupo de pessoas não vale necessariamente para outro. Também tinha como referência o grupo do qual participei durante sete anos, que a partir de certo momento, passou a atuar sem direção, sem condução externa. Acontece que muito tempo se passou até chegarmos ao ponto de realmente termos essa autonomia, além de essa experiência não servir como exemplo para outra, com outras pessoas, em outro contexto.

O ponto ao qual chegamos foi: mesmo com a finalização de um processo autônomo em que todos são criadores, a presença do orientador é importante. O aquecimento é a continuidade do processo de ensinoaprendizagem. Pode-se dizer que chegamos mais uma vez à constatação de que os processos de criação e aprendizagem não podem ser apartados.

Geralmente, os grupos têm dificuldade em repetir um mesmo exercício. Muitas vezes cobram do professor um vasto e diversificado leque de propostas. Essa atitude é coerente com a relação estabelecida com o tempo na contemporaneidade: há excesso de informação, fugacidade na apreensão e, rapidamente, falta de interesse. Os grupos tendem a lidar com os jogos como produtos descartáveis e não experiências a serem vivenciadas. "Walter Benjamin, em um texto célebre, já observava a pobreza de experiências que caracteriza o nosso mundo. Nunca se passaram tantas coisas, mas a experiência é cada vez mais rara" (BONDÍA, 2002, p.21). Portanto, determinados jogos de atenção e prontidão precisam ser repetidos, pois a cada dia, o que nos acontece e nos toca é diferente e só podemos percebê-lo se repetirmos os mesmos jogos. O autor ainda afirma que a experiência é cada vez mais rara por falta de envolvimento com assuntos específicos e dificuldade de escolha de focos de interesse (Ibidem, p.23). 
O acontecimento nos é dado na forma de choque, do estímulo, da sensação pura, na forma da vivência instantânea, pontual e fragmentada. A velocidade com que nos são dados os acontecimentos e a obsessão pela novidade, pelo novo, que caracteriza o mundo moderno, impedem a conexão significativa entre acontecimentos. Impedem também a memória, já que cada acontecimento é imediatamente substituído por outro que igualmente nos excita por um momento, mas sem deixar qualquer vestígio. (...) Ao sujeito do estímulo, da vivência pontual, tudo o atravessa, tudo o excita, tudo o agita, tudo o choca, mas nada lhe acontece. Por isso, a velocidade e o que ela provoca, a falta de silêncio e de memória, são também inimigas mortais da experiência.

\section{Coleção dos Jogos do Olhar- Corpo}

Seguem alguns exemplos de exercícios inspirados nas proposições de Anne Bogart, os quais não foram propostos exatamente como a autora os descreve, são, portanto, versões pessoais dos exercícios indicados por ela:

\footnotetext{
Visão periférica:

Pede-se para o grupo deslocar-se pelo espaço com presença. Segundo Bogart, presença diz respeito ao interesse pessoal naquele momento, portanto é algo que não pode ser falso ou indicado (relembra as cinco imagens para reforçar a presença corporal, descritas na p. 92). Cada um deve escolher uma pessoa para observar, sem deixá-la perceber que é a escolhida e sem deixá-la em nenhum momento fora do campo de visão, olhando-a com o olhar periférico: receber as informações sobre a pessoa, observando as cores de sua roupa, sua pele, suas formas e o ritmo de seu caminhar, ficar atento ao momento em que deixar de agregar informações e se desinteressar. Como manter o interesse e conseqüentemente, a presença cênica? Depois de mais 1 minuto, deixar a pessoa sair do campo de visão. Escolher outra pessoa, observar as diferenças e senti-las. Depois de 1 minuto, agregar mais uma pessoa à visão periférica, mantendo as duas no campo de visão. Aos poucos, adicionar mais pessoas, ampliando cada vez mais o campo de visão. Voltar a caminhar simplesmente, sem perder a "presença" e o interesse.
} 


\section{Corra para o centro:}

Formar um círculo bem grande no espaço. Uma pessoa pode a qualquer momento iniciar uma corrida até o centro. Todos devem correr ao centro, em consenso, de tal forma que quem estiver de fora não perceba quem iniciou o movimento. O objetivo do grupo é voltar junto para a grande roda, também em consenso, sem necessariamente ocupar os mesmos lugares.

\section{Círculo das três regras:}

Formar um círculo em que todos caminham na mesma direção, mantendo a mesma velocidade e o mesmo intervalo espacial entre os integrantes.

Regra 1: sem ninguém iniciar, o grupo inteiro deve mudar de direção ao mesmo tempo, girando para dentro do círculo, sem diminuir a velocidade para mudar a direção. O grupo deve buscar consenso mútuo para agir junto, de forma precisa e sucinta.

Regra 2: todos param voltados para dentro do círculo e, em consenso, saltam, voltam para o chão juntos e retomam a caminhada na direção oposta. Regra 3: alguém do grupo propõe uma pausa e todos reagem parando ao mesmo tempo. Todos se olham e voltam a caminhar na mesma direção. Acrescentar as regras consecutivamente e deixar o grupo passar por elas de forma aleatória. Uma variação possível é propor um número de mudanças de direção (12), saltos (6) e pausas (4), as quais podem ser contadas por alguém de fora da roda, sempre revelando quantas mudanças, saltos ou pausas faltam. É importante que o grupo busque executar as regras em consenso, como se fosse uma jogada ensaiada.

\section{Grade ou Raia:}

Iniciar na pausa e deslocar-se no espaço traçando linhas paralelas e perpendiculares, evitando curvas e diagonais, como se desenhassem uma grade no chão. Na pausa, explorar movimentos com alguma articulação ou parte do corpo pré-estabelecida. Tanto os deslocamentos quanto os movimentos propostos são reações, respostas ao movimento de alguém ou a algum estímulo do espaço. Caminhar variando as distâncias entre as pessoas 
e as paredes. O jogo pressupõe escuta, deixar-se influenciar pelo outro e fazer pausas.

A mesma proposta pode ser realizada com outro desenho no espaço: raias, como as de uma piscina. Inicia-se em uma linha, na qual todos os jogadores estão posicionados para a mesma direção, no fundo da sala, como se estivessem diante de raias. Recomenda-se iniciar com no máximo cinco integrantes, para que eles possam efetivamente mover-se em resposta a alguém.

\section{Filmes como modelo de ação e estoque de imagens}

“A vida cotidiana, religiosa, ou artística consiste em grande parte em rotinas, hábitos e ritualizações e de recombinação de comportamentos previamente exercidos. O que é novo, original, chocante, ou 'avant garde' é, quase sempre, uma recombinação de comportamentos conhecidos, ou o deslocamento de um comportamento do lugar que ele é aceitável ou esperado, para um espaço ou situação em que este seja inaceitável ou inesperado".

Richard Schechner

O processo de criação teatral, detalhado até agora, envolveu a relação dos corpos com o espaço, inicialmente estáticos. Somente neste presente capítulo começamos a tratar da imagem em movimento, ou seja, da imagemtempo. Durante o treinamento e o aquecimento corporal houve movimento; no entanto, as primeiras imagens "cênicas" que compusemos eram estáticas. Para a proposição de movimentos vinculados a essas imagens, alguns recursos foram utilizados, considerando-se os seguintes atributos: duração, andamento, repetição e resposta kinestésica, como já explicitado.

Após a definição dos enquadramentos e a composição das imagens estáticas como forma de apropriação do espaço, proponho que os jogadores se relacionem com ele como se fossem crianças extraterrestres. Essa instrução veio de jogo proposto por Marcos Bulhões. A idéia consistia em desbravar o espaço como crianças alienígenas que desconhecem os objetos encontrados no local, assim como sua função e seu modo de uso. Esse convite ao estranhamento de espaços e objetos cotidianos coloca o jogador numa verdadeira postura de descoberta. Vale cheirar, tocar, perceber todas as informações latentes nele, colocando-se como um corpo curioso. Acrescentei a essa proposta instruções mais diretas a respeito da investigação da 
materialidade do espaço: perceber materiais, cores, texturas, cheiros, formatos. Paralelamente a isso, propus perceber as sensações desencadeadas na relação do corpo com os materiais encontrados no lugar. Em seguida, sugiro que os jogadores meçam o recorte com partes de seu corpo, desenvolvendo uma relação direta do corpo com o espaço. Os jogadores selecionam alguns trechos de seu exercício e apresentam essa síntese, uns aos outros.

Outra forma de dotar de movimento a imagem fixa é a partir da apresentação dos segmentos espaciais do espaço cinematográfico. Traduzindo para a experimentação teatral, o ator pode explorar esses segmentos em suas entradas e saídas do recorte espacial. É da natureza do cinema referir-se a dois espaços: o de dentro e o de fora do quadro, como se fossem duas imagens, o que está em quadro e o que está fora dele. Por se tratar de um teatro que explora a arquitetura na qual se instala, podemos nos referir a eles utilizando os espaços dentro e fora dos enquadramentos sugeridos pelos limites arquitetônicos. Uma cena exemplar desse modelo foi chamada de " $3 \mathrm{x}$ 4". O espaço cênico foi estabelecido em dois corredores, um sobre o outro, que ressaltavam a verticalidade da Hidráulica. O público posicionado em uma das plataformas, portanto acima do nível do chão, observava os atores através das vidraças que revelavam os corredores que constituíam o espaço cênico (imagem utilizada no cartaz da segunda Sessão de Cinema dos Jogos do Olhar).

Para os objetivos desta discussão, a definição de espaço do campo (ou do quadro) é extremamente simples: constitui tudo o que o olho percebe na tela. O espaço-fora-da-tela ou quadro é, neste nível de análise, de ordem mais complexa. Divide-se em seis 'segmentos': os limites imediatos dos quatro primeiros segmentos são determinados pelos quatro cantos da tela (...). O quinto segmento não pode ser definido com a mesma (falsa) precisão geométrica e, no entanto, ninguém contestará a existência de um espaço-fora-da-tela, 'atrás da câmera' (...) mesmo que as personagens tenham acesso a ele passando geralmente à esquerda ou à direita da câmera. Enfim, o sexto segmento compreende tudo o que se encontra atrás do cenário (ou atrás de um elemento do cenário): tem-se acesso a ele saindo por uma porta, contornando a esquina de uma rua, escondendo-se atrás de uma pilastra ou de uma personagem. (BURCH, 1969, p. 37-38) 
No caso da cena descrita acima, os jogadores podiam entrar no recorte espacial pelos lados ou de baixo para cima, pois as vidraças revelavam seus corpos apenas da cintura para cima. Portanto, diferentes partes do corpo dos jogadores entravam inicialmente em quadro, variando as partes do corpo visíveis ao público. Apesar de não vermos os atores como um todo, do ponto de vista dos espectadores, a movimentação de partes do corpo fora de quadro reverberava na parte visível. Esses efeitos foram bastante explorados pelos jogadores, conscientes daquilo que era projetado para a vista do público, uma vez que o enquadramento constituído pelas janelas dos corredores ajudava a diferenciar a área de jogo (campo) da área do não-jogo (fora de campo).

Uma maneira recorrente de mobilizar as imagens estáticas acontecia por meio da definição de uma ordem de apresentação de três imagens escolhidas e da exploração de diferentes transições de uma fotografia a outra. Uma indicação possível para os jogadores é recomendar que parem em cada imagem e pensem na próxima, procurando perceber quais impulsos os direcionam para a outra imagem. Esse impulso pode vir de apenas um dos jogadores ou de todos ao mesmo tempo, seguindo as propostas de Anne Bogart no treinamento da resposta kinestésica. A passagem de uma imagem a outra pode variar em relação às suas qualidades, podendo constituir-se por um rompante ou por um acordo instaurado lentamente. A utilização de sons pode ajudar os componentes da fotografia a concretizarem esse impulso de mudança.

A passagem de uma imagem a outra envolve deslocamento espacial dos atores, o que corresponderia na linguagem cinematográfica ao procedimento intitulado plano-seqüência: um plano longo que acompanha a ação dos atores, sem cortes. Por hora, esses planos-seqüência caracterizavam-se por manter a câmera (a platéia) mais ou menos fixa. Nesse ponto do processo transformamos planos fixos em planos-seqüência, pelo deslocamento dos atores. Se o olhar do público cumpre o papel da câmera, o público também está livre para acompanhar a cena, deslocando-se para melhor acompanhá-la. Entretanto, não nos referimos aqui aos deslocamentos que a encenação propõe ao público, o que chamamos de travellings. A instrução era convidar o olhar do público para percorrer a imagem cênica acompanhando o percurso de 
alguém, de um som que atraísse a atenção, de alguém que se escondesse, desaparecesse, e de outra pessoa que eventualmente aparecesse em outro ponto do quadro. A idéia era colocar algumas imagens estáticas em seqüência, criando ligações entre elas.

Todas as modalidades elencadas acima tinham como finalidade definir uma seqüência de "ocupações" do espaço, imagens em deslocamento direcionadas a um observador fixo. Utilizamos ainda uma proposta emprestada do encenador canadense Robert Lepage para a composição de partituras vinculadas ao espaço. Mais uma vez considero relevante ponderar que se trata de uma versão do jogo, adaptado para as necessidades dessa pesquisa. Cada jogador escolhe um espaço e alguns recursos para lidar com ele. É importante ressaltar que recurso é diferente de estímulo, pois o estímulo é pessoal, cada performer pode descobrir estímulos específicos para a sua ação/atuação. Entretanto, o recurso é comum a todos e pode realmente ser "qualquer coisa": uma cadeira, um biombo, uma janela, um projetor de slides ou um sofisticado programa de computação gráfica em três dimensões. O termo empregado por Lepage é proveniente do teatro-dança, por isso propõe que os performers lidem com a materialidade dos recursos, como se fossem brinquedos. Para ele, a tecnologia é ferramenta que serve também para revelar os mecanismos de construção da cena. O interessante de se pensar em "recurso" para a composição é que não há jamais "falta" de recurso, mesmo nos ambientes mais precários, pois a criação será feita com os meios à disposição. Desse modo, o recurso é um ponto de partida, um material ou espaço para se relacionar na composição da cena.

Retomando a proposta: cada jogador escolhe um espaço e os recursos para se relacionar com ele, define um ponto de partida e um ponto de chegada. Tais escolhas constituem uma partitura que deve ser transformada em anotação, um desenho com indicações dos pontos de partida e chegada e algumas indicações de interações com os recursos disponíveis. Na concepção de Lepage, score ou partitura é como uma partitura musical, um fragmento lógico. Não se trata de uma estrutura acabada, depende de quem a executará. O encenador também não considera a partitura um evento ou acontecimento definido pela dupla "causa e efeito"; trata-se de estrutura flexível, que poderá 
ser manipulada. Por isso, propõe que os jogadores troquem suas anotações e experimentem as partituras uns dos outros. O curioso na proposta de Lepage é o trabalho com o imprevisível que vem do outro e o exercício do desapego da idéia inicial. A troca de "projetos de partitura" amplia significativamente as possibilidades de criação, uma vez que um jogador entrega a proposta de partitura "no papel" para outro, sem tê-la realizado anteriormente. Todas as explorações são surpreendentes, pois cada jogador, ao executar uma anotação, coloca impressões e dados singulares na relação que estabelece com os recursos. Algumas vezes devolvemos a "cena" ao propositor de origem; em outras, as cenas permaneceram trocadas. O fato recorrente nesse caso, é que após ter sido experimentada por outra pessoa, a cena não será jamais a mesma. No contexto da criação coletiva, esse princípio pedagógico ressalta a importância do partilhamento das vozes na autoria da encenação. Embora haja diferentes funções sendo exercidas, não cabe a ninguém em particular a autoria das cenas. Elas resultam de uma ação conjunta.

Partindo da composição de imagens e seguindo procedimentos identificados na linguagem cinematográfica, o teatro experimentado ainda tratou o filme como um modelo de ação. Esse conceito foi desenvolvido por Bertolt Brecht no estudo de suas peças didáticas. "Os 'modelos de ação' são determinados, ou seja, nitidamente delineados, isoláveis em suas partes para que possam ser julgados ou imitados. [...] Característica do modelo é sua reprodutibilidade por qualquer pessoa" (KOUDELA, 1991, p. 135). Embora Brecht proponha que um texto seja o modelo, a professora Ingrid Koudela apresenta em seus estudos a possibilidade de pinturas serem tomadas como modelo. Dando continuidade a essa licença, usamos aqui filmes como modelos de ação. De acordo com Brecht, o extremo oposto de lidar com o texto como modelo de ação seria realizá-lo literalmente, o que nessa proposta corresponderia à adaptação de um filme para o teatro. Como esse não é nosso objetivo, tomamos o filme como modelo, trazendo-o para o cotidiano dos jogadores que se sentem livres para manipulá-lo, questioná-lo e reinventá-lo. 0 filme torna-se uma inspiração; "objeto de imitação crítica, ele se constitui enquanto princípio unificador do processo pedagógico, o que propicia liberdade e diversidade de respostas, por meio da historicização, ou seja, da contextualização do modelo" (Idem, 2001, p. 46). 
Esse instrumento didático proposto por Brecht, aliado ao instrumental apresentado pela Técnica Klauss Vianna, dotou os jogadores de referências para a observação de ações presentes nos filmes e suas transposições para o contexto das cenas teatrais criadas. Às seqüências de imagens, introduzimos ações físicas em certas posições ou nas passagens entre uma fotografia e outra. Depois de selecionadas, as ações eram estudadas a partir de alguns referenciais: nível espacial (alto, médio ou baixo), articulações envolvidas na movimentação, qualidades do movimento (direto ou flexível), tônus corporal, andamento e direção no espaço. Depois, as mesmas ações eram reproduzidas dentro das partituras teatrais. Adotamos uma concepção de ação física, derivada da pesquisa do ator, diretor e teórico russo Constantin Stanislávski, a qual se refere a ações psicofísicas como ações simples executadas corporalmente. Matteo Bonfitto, em sua abordagem sobre o ator-compositor, distingue ação de gesto, da seguinte maneira: "a ação é um signo, e portanto representa, significa, mas não particulariza; o gesto significa, mas ao mesmo tempo particulariza" (BONFITTO, 2002, p. 108).

Tomar um filme como modelo de ação amplia as margens do diálogo entre as duas linguagens, pois um filme é um objeto estético e estilístico, provocador de estímulos diversos, portador de referências e citações próprias. Ao adotar esse instrumento didático, houve de fato a apropriação dos filmes selecionados, uma vez que os jogadores passaram a lidar com o material fílmico de modo menos tímido, ousando recontextualizar situações, inspirar-se em personagens, fazer citações e pegar músicas emprestadas.

No contexto desse teatro de imagem, a escritura cênica indica o trabalho de composição que se efetua inicialmente no espaço articulado com os corpos que o ocupam, resultando assim em pensamento-imagem. Essa escritura é fundada sobre um alfabeto contaminado, pois resulta da colagem e da montagem de som, música, iluminação, gesto e movimento muitas vezes já existentes. Os objetos estão no mundo e o que o criador faz é apropriar-se deles. Não há nesse momento histórico atual a necessidade de ineditismo. Apropriação é reciclagem, essa é a palavra de ordem. Há muita imagem no mundo, o que temos a fazer é reciclá-las! 
Duas ações relacionadas à dança foram observadas no filme "São Paulo S/A", de Luiz Sérgio Person: a dança a dois de Carlos e Luciana, de rostinho colado, e a dança do carnaval solitário de Hilda. A primeira foi reproduzida pelo par romântico da encenação vivenciado por Adriane Escher e Daniel Cordova. O casal dançou um bolero no alto da última plataforma da Hidráulica, observado pelo público que tinha sua atenção dividida entre a cena em si mesma e a imensa sombra do casal projetada em uma das paredes do galpão. A música da cena era "Sabor a mi", de Álvaro Carrillo, utilizada em dois filmes da coleção: "Bandido da Luz Vermelha", de Rogério Sganzerla, e "Toda nudez será castigada", de Arnaldo Jabor. A dança de Hilda também teve como palco a plataforma 3 (a mais alta) da Hidráulica. A transposição dessa ação realizouse para um contexto anárquico, em que duas figuras femininas comemoram ao mesmo tempo um pedido de casamento e a queda de pequenos aviões de papel. Do mesmo filme, extraímos também a ação de esquiar, utilizada por Daniel Cordova em uma das passagens da cena "piscina amarela". Somada à dramaticidade da música "Vuelva al Sur", de Astor Piazzolla, o ator enfatizava os desequilíbrios provocados pela ação com a execução de sons que complementavam a atmosfera grandiosa sugerida pela imagem.

Algumas ações foram retiradas do filme "O Dragão da Maldade contra o Santo Guerreiro", de Glauber Rocha e introduzidas em contextos diversos de ISAURA S/A, embora o filme já estivesse fora da seleção dos filmes que seriam usados como modelo de ação (apenas "O Bandido da Luz Vermelha" e "São Paulo S/A"). No filme, há uma cena (descrita no capítulo anterior) em que Antônio das Mortes e Coirana lutam mantendo um lenço vermelho separandoos pela boca. A mesma ação foi utilizada na encenação teatral por duas atrizes, como modo de conduzir o público. Há no filme também duas cenas de morte das quais nos apropriamos. A primeira é uma cena em que a personagem de Odete Lara esfaqueia o delegado, seu amante, e a segunda é a encenação da clássica morte do dragão. Ele é representado no filme pelo Coronel, morto pelas mãos de Antão, do alto de um cavalo branco, levando a Santa na garupa. A morte por punhal foi usada na cena da sombra em ISAURA $\mathrm{S} / \mathrm{A}$, em que o político mata sua amante com o mesmo objeto que anteriormente havia representado seu falo. O movimento de cravar a lança no peito do dragão foi transportado para a cena intitulada "piscina amarela", em 126 
que uma figura masculina (morto na cena final, no lugar do cangaceiro) realiza a movimentação na qual uma figura feminina simula ser golpeada. Como a cena era vista de muito longe, a obviedade do "faz de conta" não incomodava. A ação que originalmente representava a tão esperada morte do dragão foi transformada em seqüência de movimento, cujo efeito era mais estilístico do que dramático. Aliás, o cineasta também reforça essa idéia repetindo a imagem da lança atingindo o Coronel duas ou três vezes; agindo assim, ele afasta-se da dramaticidade e aproxima-se de um comando, como se sussurrasse através da tela: "matem os dragões, senhores espectadores, matem os dragões..."

Nesse ímpeto de reciclar, algumas vezes os jogadores "reproduziram" as cenas dos filmes, ao invés de pinçar ações e recontextualizá-las. Pode-se dizer que, nesses casos, os filmes foram utilizados como estoque de imagens para a composição teatral, do mesmo modo que alguns encenadores utilizam fotografias, pinturas, esculturas, enfim, imagens diversas como estoques de imagem. Exemplo disso foi a cena apresentada na cabine de comandos na plataforma 2 da Hidráulica. Em certo momento do processo criativo, fizemos um levantamento de espaços ociosos pelos quais passávamos ao longo do roteiro de cenas criadas. Alguns subgrupos manifestaram seu desejo de desenvolver propostas cênicas nesses locais. Sem seguir a indicação inicial de composição partindo de fotografias, disseram: "Vamos fazer a cena em que o Bandido da Luz Vermelha está na cozinha experimentando vários pares de óculos aqui”.

$$
\text { (protocolo de Katia Lazarini) }
$$

"Fomos para a cabine: como chegar? Como ocupar esse espaço? Organizamos os materiais da cena procurando encontrar as melhores opções. Nossa cena foi uma cópia ou releitura integral de uma cena do filme. Como transpor para o teatro? Como recortar? Por onde mostrar? [...] Apresentamos, foi muito bom ver novas idéias ocupando o espaço, a Paulinha pulando muros, a Caru cuspindo água, a Katinha com as malas... Lentamente os filmes estão chegando na Hidráulica e preenchendo com algum sentido o percurso dessas personagens."

Assim sendo, selecionaram algumas ações realizadas pelo bandido no filme, tais como: experimentar pares de óculos, beber mistura de diversos alimentos batidos no liqüidificador, usar spray contra mau hálito e beijar. Ordenaram essas ações de modo coerente com a ocupação da cabine que propuseram e apresentaram para o Coletivo. Com o passar do tempo, outra 
ação foi agregada à cena como efeito de repetição, e citação de outro momento em que aquelas figuras apareceram juntas. A ausência de um dos jogadores também influenciou na reestruturação dessa cena. Segue abaixo um exemplo de cena adotada como estoque de imagem:

\section{“O Dragão da Maldade contra o Santo Guerreiro”, de Glauber Rocha.}

A cena de apresentação dos créditos do filme é um plano-seqüência didático na demonstração dos dois espaços constitutivos da cena cinematográfica: o de dentro e o de fora do quadro. Inicialmente, ouvimos sons distorcidos de tiros, misturados a outros ruídos. Observado por uma câmera fixa, entra no quadro Antônio das Mortes, pelo segmento espacial direito, e atravessa o espaço enquadrado disparando tiros contra um alvo fora de campo. Ouvimos sons que revelam que seu alvo foi atingido. Do segmento esquerdo da tela, mesmo lado do qual saiu o matador, entra um cangaceiro estrebuchando até cair morto.

A cena sintetiza a estória de Antônio das Mortes, o matador de cangaceiros que vivenciará na trama do filme uma crise de consciência. Glauber é magistral ao compor o plano com uma simplicidade que o aproxima do teatro. O espaço enquadrado de forma fixa poderia ser comparado ao palco de um teatro à italiana.

Na cena de ISAURA S/A composta a partir da cena de Glauber, o recorte do espaço era sugerido por um dos grandes portões do galpão, aberto. $\mathrm{O}$ público assistia à cena de dentro do Laboratório e os atores estavam posicionados do lado de fora. Optamos por apresentar três entradas de personagens e não as duas propostas na cena-estoque. Primeiro, o personagem atingido pela bala cruzava o espaço, da direita para a esquerda. Depois, do mesmo segmento (lateral da imagem que conduz ao espaço fora de campo) do qual saiu o ator baleado, sai a noiva simulando carregar um rifle. No meio do caminho, atira e continua caminhando até sair de quadro. Do mesmo lado, sai o ator baleado agora estrebuchando e cai no centro do espaço dizendo "Foi assim que eu ensaiei", frase de fechamento da encenação. A escolha dessa frase testemunha nossa vontade de que a peça fosse entendida 
como um ensaio, não um ensaio na acepção teatral, mas o ensaio na acepção literária.

\section{Coleção dos Jogos do Olhar - Espaço + Corpo + Tempo}

As modalidades de jogo abaixo se referem à percepção da temporalidade. O primeiro jogo é um desenvolvido do "Jogo de composição de fotografias". Os dois jogos adiante servem de diagnóstico sobre a percepção da passagem do tempo e de treinamento para a sua manipulação, por parte do jogador que está inserido no jogo. Ambos podem ser desdobrados e desenvolvidos de acordo com a situação que se cria em cena.

\section{Composição de seqüência de três fotos}

Jogo desenvolvido a partir da modalidade anterior (composição de imagens fixas) $)^{25}$. Primeiro os jogadores escolhem três imagens experimentadas durante a exploração do espaço. As imagens são colocadas em uma ordem escolhida pelos jogadores, que, em seguida, criam passagens de uma "foto" a outra. Aconselha-se sempre buscar um caminho a partir do corpo (quais os impulsos para se chegar à próxima imagem?), orientando-se pelos movimentos necessários para a mudança de posição e não por motivações dramáticas. Cabe ao espectador (os outros jogadores) realizar, mais uma vez, a leitura do "plano-seqüência" criado.

\section{Linha dos 5 minutos}

Todos os jogadores alinhados ombro a ombro, no fundo da sala, buscam chegar até a frente da sala em cinco minutos. Cada jogador caminha no seu tempo, enquanto isso o coordenador pode anotar o tempo de chegada de cada um e depois apresentar a média da percepção do tempo do grupo.

\section{Ir até o chão em 1 minuto}

\footnotetext{
${ }^{25}$ A autora aprendeu esse jogo com a companheira de grupo e de muitas parcerias artísticopedagógicas, Paulina Caon.
} 
Todos os jogadores procuram chegar ao chão (ficar deitados) em 1 minuto. Eles podem tanto tentar levar um minuto para chegar ao chão, quanto esperar o tempo de 50 segundos de pé e descer ao chão em 10 segundos.

\section{Roteiro: sucessão de planos e travellings para o público}

"O teatro é uma anarquia que se organiza" Jacques Derrida

No minucioso trabalho de entrelaçamento dos fios "abertos" no levantamento de material para a encenação, organizou-se um subgrupo dentro do Coletivo que chamamos de Núcleo de Dramaturgia. Esse núcleo realizou uma espécie de leitura do material cênico, observado à distância, pois nos encontrávamos em horários diferentes dos ensaios. Nesses encontros levantávamos hipóteses sobre a recepção das cenas, exercitando colocarmonos no lugar do público, lendo as escolhas da encenação. Definições como o encadeamento das cenas, o percurso do público, a configuração de diferentes versões do roteiro, os sentidos esboçados, as sensações despertadas eram debatidas no Núcleo de Dramaturgia. Uma das participantes, Katia Lazarini, teve papel fundamental na coleta de propostas para se pensar a dramaturgia. Interessada em desenvolver uma proposta de pesquisa que fundava a dramaturgia sobre o jogo teatral, Katia foi uma colaboradora de fôlego inesgotável.

Desde a definição dos enquadramentos e respectivos pontos de vista, houve a preocupação com a recepção da encenação. Tanto é, que antes mesmo de observarmos as imagens em movimento, voltamos nossa atenção à ordenação da apresentação das imagens. Como se tratava de um espaço não teatral, o local destinado ao público precisava ser pensado; buscou-se então definir uma trajetória o quanto antes. A Hidráulica era cheia de escadas e desníveis, fatores preocupantes no tocante à segurança do público, por isso desde o início fomos alertados e cobrados em relação à definição dos locais permitidos ao público. O percurso traçado pelo público durante a encenação foi definido considerando-se a acessibilidade de maneira segura e o princípio geométrico do teatro, como lugar de onde se vê. Em apenas dois lugares os espectadores tinham assentos fixos para observarem as cenas, na maior parte 
do tempo tinham certa mobilidade diante delas. Assim, a relação com a locação teatral direcionou a definição do roteiro, ou seja, a ordem da sucessão dos planos exibidos. Esse roteiro foi definido por um dos jogadores (no protocolo transcrito abaixo) de roteiro geográfico.

(Protocolo de Daniel Cordova)

"Encontrar a ordem no caos. Aqui eu penso que era a momento em que poderíamos ter nos dedicado a pensar o sentido da ordem das cenas, ou seja, de um modo não só geográfico. A minha questão tem a ver com a dificuldade de construção de sentido no fim do processo."

A escolha por definir um roteiro geograficamente se deve ao interesse em se construir um discurso a partir da releitura do Laboratório de Hidráulica e não um discurso calcado na relação causa e efeito. Ou seja, não havia busca por construir uma narrativa que justificasse a seqüência de apresentação das cenas; elas estavam apenas dispostas lado a lado no espaço da encenação. Embora haja uma porcentagem significativa de acaso nesse modo de composição, pois o roteiro se define pela disposição espacial, o discurso que se constrói está vinculado à presença de uma montagem, uma vez que não há um narrador conduzindo a mudança das cenas. Havia falsos narradores que apareciam para iludir o público, fazendo-o acreditar que seria levado pela mão. O exemplo do cão que guiava o público na primeira seqüência de cenas da encenação é metafórico, se lembrarmos que, geralmente, os cães guiam os cegos. O público, então, seria esse convidado cego, guiado por um cão não confiável, pois abandonava os espectadores no primeiro terço da encenação.

Em um primeiro momento, definimos a ordem das seqüências, combinando a sucessão de imagens estáticas e não propriamente de cenas que envolvessem movimento. Desse modo, as cenas também se desenvolveram no que se refere aos sentidos esboçados, em função dessa geografia. A maneira pela qual conduzimos a composição das cenas caracteriza-se pela sobreposição em camadas dos elementos cênicos. Após definir os pontos de vista e os enquadramentos, ocupamos o espaço com o corpo, dotamos o corpo de movimento e, conseqüentemente as cenas e as transições entre elas. A partir de então, sentidos podiam ser identificados e textos recolhidos para a última das sobreposições. 
"A discussão sobre a dramaturgia junto com o grupo foi muito importante para podermos clarear juntos a trajetória que estamos construindo. [...] O procedimento de colagem, ou melhor, sobreposição - CORPO, CORPO em relação ao ESPAÇO, CORPO e ESPAÇO em relação a

TEMPO, CORPO, ESPAÇO e TEMPO em relação ao TEXTO parece pertinente para a construção de uma dramaturgia não linear, onde uma história qualquer sequer é mencionada. Favorece uma dramaturgia de imagens, construída a partir do corpo dos atores, organizados

em partituras "cuja combinatória forma a própria fábula" (Patrice Pavis). Ainda que não pensemos em uma fábula, cada escolha, cada nova peça encaixada à engrenagem reconfigura os sentidos e acrescenta uma nova informação à nossa narrativa."

Para a formatação da ordem dos planos pensávamos na reação dos espectadores ao entrarem pela primeira vez na Hidráulica. Como apresentar aquele espaço aos poucos para as vinte e cinco pessoas do público? Para explorar bem o percurso, valorizando seus momentos de destaque, elegemos as imagens caras ao processo. Como o público se relacionava com a obra em deslocamento, o espaço circunscrito do teatro citado por Malraux no excerto abaixo, foi destruído por meio da substituição do tablado do palco por espécies de planos cinematográficos.

Enquanto o cinema não foi mais do que um meio de reprodução de personagens em movimento, não foi mais arte do que a gravação sonora ou a fotografia de reprodução. Num espaço circunscrito, os atores evoluíam, representavam peça ou farsa que a câmera se limitava a registrar. O nascimento do cinema como meio de expressão (e não de reprodução) data da destruição deste espaço circunscrito: da época em que o decupador imaginou a divisão do argumento em planos e procurou, em lugar de fotografar uma peça de teatro, registrar uma sucessão de instantes, aproximar a câmera (fazer crescer os personagens na tela quando necessário) ou recuála; sobretudo substituir o tablado de um teatro pelo "campo", o espaço que será limitado pela tela e que o diretor da cena escolheu, em vez de ser dele prisioneiro. O meio de reprodução do cinema era a fotografia que se movia, mas seu meio de expressão é a sucessão de planos. (MALRAUX, 1959, p. 90)

Uma imagem determinante dessa ordem foi a panorâmica, o melhor ponto de vista para observar o galpão como um todo e único momento em que todas as luzes do galpão seriam acesas. Todos os portões de acesso ao Centro Tecnológico de Hidráulica situavam-se do mesmo lado, com exceção de uma 
pequena entrada que para ser utilizada demandaria alterar a rota da chegada das pessoas no prédio. Convencidos de que a chegada mais óbvia seria por um dos portões, percebemos que o roteiro teria uma característica cíclica, cujo circuito poderia começar pela direita ou pela esquerda. Como o ponto de vista para a imagem panorâmica era à esquerda e não queríamos começar revelando o espaço todo, optamos por iniciar o circuito pela direita. Não sem antes englobar o modelo físico reduzido que apelidamos de "aquário", cubo com uma parede de vidro, espaço de múltiplas possibilidades de ocupação, que poderia ser visto no início e no final da trajetória.

Após a observação de algumas versões do roteiro, com pequenas variações na ordem das cenas, pelo teor de recorte e colagem da encenação, já previa que não chegaríamos a contar uma estória, a não ser que forjássemos a escrita de uma narrativa que se inscrevesse em todas aquelas imagens levantadas. Da primeira à última versão do roteiro, pouco se alterou o percurso do público. De certo modo intuía-se que a questão não era de ordem geográfica, mas relacionava-se ao nível de desenvolvimento de cada fragmento. Prova disso é que as cenas mais plenamente resolvidas surgiram das imagens mais interessantes criadas nos primeiros ensaios na Hidráulica. Nossa lista de imagens caras incluía as cenas conhecidas como: "piscina amarela", "3 x 4", "plongée” e "panorâmica" (Ver Roteiro Hidráulico, no anexo IV).

Uma das propostas do Núcleo de dramaturgia nessa ocasião foi a confecção de cartões com os nomes das cenas para serem posicionados no espaço, reconstruindo-o. Esse jogo foi posterior à tentativa, no momento de apropriação do espaço, de desenhar o galpão aproximando-se cada vez mais de suas proporções. Os primeiros desenhos da Hidráulica pareciam um plano de realização impossível. Eles descreviam justamente a rota do público, um plano meticuloso, permeado de desvios e espaços vazios. Quando já havia cenas suficientes em todo o trajeto percorrido, aumentou nossa sensação de preenchimento do espaço. 
(protocolo de Daniel Cordova)

"Quero fazer o passadão. Ver que cara isso está. Faz tempo que não fazemos. Sinto falta de conexão entre as coisas, não no plano do significado, mas da leitura espaço-temporal mesmo. Quero descobrir também lacunas em que se possam encaixar mais ações dos filmes."

Conhecendo o grande esboço do roteiro e em diferentes momentos do processo sujeito às entradas e saídas de jogadores, fizemos algumas passagens do roteiro todo para diagnosticar as lacunas na ocupação do espaço. Identificados os recortes ainda inexplorados, concentramos esforços na criação de cenas em subgrupos e, paralelamente, na leitura daquelas que se consolidavam.

A montagem a qual se chegava não correspondia a uma progressão linear, em que um plano é encadeado a outro. Aparentemente, o que construímos aproxima-se do que Eisenstein chamou de montagem disjuntiva, uma progressão de cenas em que a descontinuidade é ostensiva. "Eisenstein prefere falar em 'justaposição de planos', ao invés de encadeamento" (XAVIER, 2005 , p. 130). Para ele, "a perspectiva correta é produzir choques - um plano conflitando com outro - para arrancar o espectador da 'atitude cotidiana"” (Ibidem, p. 133). Os integrantes do Coletivo costumavam brincar entre eles com a seguinte expressão: "Pensa imagem, não pensa palavra"; quando alguém contava alguma estória engraçada ou fazia alguma associação de palavras curiosa. Coincidentemente, ou talvez porque algumas coisas continuam no "ar do nosso tempo", o cineasta russo propunha na década de 1920 "um cinema que 'pensa por imagens' em vez de 'narrar por imagens"” (Ibidem).

\section{(Protocolo de Paula Bellaguarda)}

"A escrita das cenas por imagens me incomoda um pouco, pois não deu conta da reflexão sobre o que escrevíamos. As escolhas para a edição eram circunstanciais - o que não

é completamente ruim - mas tornava irrelevante a escolha de um discurso cênico. Aspecto este que na etapa anterior era bastante importante tanto na escolha do espaço como na criação das cenas que emergiram desse espaço."

O protocolo acima revela dificuldades intrínsecas aos processos criativos que propõem pontos de partida, e, sobretudo, pontos de chegada não convencionais. Não concordo que a escolha do discurso cênico fosse irrelevante; atribuo tal insatisfação com a escrita por imagens aos atropelos do 134 
final do processo da encenação, em que tivemos que fazer escolhas apressadas e sem passar pelo crivo de todos os artistas do Coletivo.

O processo de composição fílmica envolve etapas que não encontram correspondências no processo teatral. A elaboração do filme compreende pelo menos dois momentos distintos: a filmagem e a montagem. A filmagem é a materialização, a concretização das cenas. Talvez o momento que mais se aproxime da realidade dos ensaios teatrais. Há a presença do ator e a vivacidade do jogo que o relaciona aos demais componentes e recursos da cena. Apesar da intenção do ator de cinema voltar-se para a câmera que pode estar muito próxima dele, ele também se dirige aos espectadores. Entretanto, tais espectadores não compartilham o mesmo espaço-tempo da realização da cena. Já na montagem, ocorre uma manipulação do material fílmico, que não é humano. Esse material é resultado da filmagem e está pronto para ser arranjado. No teatro não há qualquer experiência semelhante a essa, no que se refere à ausência do material humano. O que se observa são algumas possibilidades de alteração e inversão na ordem das cenas, assim com a aplicação de outros recursos como repetição, justaposição e simultaneidade.

\footnotetext{
Qualquer um que tem em mãos um fragmento de filme a ser montado sabe por experiência como ele continuará neutro, apesar de ser parte de uma seqüência planejada, até que seja associado a um outro fragmento quando de repente adquire e exprime um significado mais intenso e bastante diferente do que o planejado para ele na época da filmagem. (EISENSTEIN, 1990, p. 20)
}

Ao perambular pela locação, o público precisava ser orientado, isto é, precisava de referências para não se sentir livre para percorrer o espaço todo ao seu bel prazer. Se a opção repousasse sobre a idéia de uma peçainstalação (estruturada por meio de cenas "instaladas" no espaço), bastaria anunciar ao público para se comportar como se visitasse uma exposição ou um museu. Como não era essa a proposta, a peregrinação pelos pontos de vista sugeridos pela encenação não se configurava de maneira tão simples. $\mathrm{Na}$ condução do público havia duas distinções claras: momentos de parar para observar a cena e momentos de assisti-las em deslocamento. A responsabilidade pelo posicionamento diante do quadro é em parte da própria 
cena, que deve atrair o olhar, em parte dos atores que propõem a condução e em parte, dos "lanterninhas", parceiros do público que iluminam o espaço e coordenam praticamente seu deslocamento, sem interferir na cena.

Chamamos os deslocamentos do público, seguindo a proposição de comparar o espectador à câmera cinematográfica, de travellings. Tal procedimento corresponde ao deslocamento da câmera, seja na mão, seja em um carrinho. A definição dos travellings para o público é muito importante na configuração geral da encenação fora do edifício teatral, pois revela um caráter processional, que significa "relativo a ou próprio de procissão" (HOUAISS, 2001, p. 2303). Embora não se trate de uma procissão religiosa, o público desloca-se coletivamente com o objetivo de que todos observem a mesma cena. Algumas vezes, ouvimos referências a correspondentes de travellings no teatro em que as cenas se deslocam, causando a ilusão de que o olhar se locomove. No entanto, considero o exemplo abaixo bastante adequado para ilustrar uma utilização explícita de travelling no teatro, em que o espectador se desloca, literalmente, ao observar a cena.

\section{"Trem Fantasma", coletivo de criadores provocados por Christoph Schlingensief:}

A instalação operística organizada pelo artista plástico Christoph Schlingensief propõe uma performance inspirada na obra de arte total de Wagner. Com vasto aparato tecnológico (dezenas de projetores de vídeo), o encenador criou um espaço sobrecarregado de informações. Sem entrar no âmbito da performance (realizada por artistas que acompanham o encenador, dois grupos convidados da cidade de São Paulo, cantores de ópera e espécies de "maquinistas" encarregados de girar grandes plataformas), nossa atenção volta-se ao obsessivo trabalho de pinçar procedimentos cinematográficos no corpo da escritura cênica.

É importante destacar que se trata de uma performance-instalação, pois todos os elementos estavam dispostos num amplo galpão nas futuras instalações do SESC Belenzinho. Cabia ao espectador deslocar-se livremente pelas "cenas" que correm num moto continuum, causando sempre a sensação 
de atraso, como se algo tivesse sido perdido. Dois momentos eram marcantes. No primeiro, há uma instalação sobre uma plataforma giratória que lembra um carrossel. Ao adentrar nesse labirinto giratório, cujo percurso também convida a andar em círculos, não se espera encontrar um ensaio de uma trupe de cantores de ópera que convidam alguns espectadores a participarem de sua tosca apresentação. Nesse caso, não é a cena que gira sozinha, todos giram, inclusive os espectadores, convidados a uma experiência sensorial de teste dos labirintos.

O segundo momento a destacar é o percurso sobre uma ampla ponte que cruza todo o espaço. Sob a ponte, há inúmeras estruturas que comportam cenas entre as quais corre o carrinho do trem fantasma. O fato cinematográfico está implicado na possibilidade de o espectador observar as cenas em plongée (ou câmera alta), sobre a ponte, e em seguida, fazê-lo de dentro do carrinho do trem fantasma, como se ocupasse o lugar da câmera, movimentada por um carrinho. Aqui o olhar do público associa-se diretamente ao olhar da câmera. Há uma particularidade nesse exemplo de travelling: é o público que se desloca pela cena estática e não a cena que se move sobre carrinhos enquanto o público está estático. Portanto, ao pensar na tradução desse procedimento cinematográfico para o teatro, pode-se fazer a cena mover, provocando a sensação de travelling no público. Porém, no "Trem Fantasma" de Schlingensief tal experiência é radicalizada, uma vez que o público "vive" o travelling.

Para concluir, é importante salientar a presença ensurdecedora da trilha sonora comandada por um DJ com repertório abrangente, do samba à reprodução dos cantos produzidos pelo grupo de cantores do carrossel labiríntico. Esse é um bom exemplo de faixa de som composta paralelamente à composição visual. Apesar de serem explicitadas concomitantemente, as faixas exacerbam o mesmo nível de experimentação; a performance tanto dos "atuadores" quanto do DJ era carregada de improviso e instabilidade, deslizando definitivamente por territórios pós-dramáticos.

No caso de ISAURA S/A buscamos formas de conduzir o público sem estabelecer quebras entre uma cena e outra, já que o espaço todo podia ser 
foco de interesse. Não gostaríamos de que o público se sentisse vivenciando uma visita guiada a uma estação de tratamento de águas. Por isso, muitas experimentações foram feitas no sentido de evitar simplesmente chamar 0 público ou fazer gestos convencionais para convidá-los a nos acompanhar. Em uma das primeiras explorações do jogo de composição de travellings, um trio de atores subiu em um carrinho rolante e compôs uma tríade que realizava sons e movimentos conectados entre si como uma engrenagem. Havia algo de "zen" nesse trio que estranhamente nos convidava a segui-los, sem dizer nenhuma palavra inteligível.

\section{(protocolo de Adriane Escher)}

"Depois partimos para a execução do roteiro. Tínhamos pouca gente, mas fizemos uma divisão boa e conseguimos realizar as 17 cenas duas vezes - apesar de alguns terem julgado,

a priori, essa tarefa quase impossível. Fizemos e foi bacana! [...] As cenas aconteceram tranqüilamente, com algumas relações mais fixas do que outras, mas a condução do público foi bem complicada. Como chamar a atenção sem pedantismo, ou manter-se interessante para ele no tempo de um travelling? Qual ação é mais instigante, qual palavra? É preciso criar uma cumplicidade com o espectador para que ele tire dessa experiência o máximo de proveito. Mas como? Ter o domínio sobre o espaço ajuda na segurança deles, mas é preciso mais, bem mais. A ação tem que também ser dominada, sendo sustentada quando necessária ou mesmo transformada. Tudo tem que ser preciso, justo. Eu estou apresentando um novo lugar, uma nova visão sobre ele e se eu perco meu olhar, meu foco, acontece o mesmo com os espectadores."

Outra condução surgiu da exploração da palavra "pacientemente", que repetida e decupada podia ser entendida como o comando "passe". Algumas soluções foram mais interessantes que outras, por exemplo: uma dupla enrolada em mangueiras encontradas no local, surpreendia o público saltando numa placa de metal e provocando um ruído bem forte. Em seguida, falavam o seguinte texto: "Sozinho a gente não vale nada"; variando o tom do discurso até falarem "então, vamos ficar juntinhos?". E assim, assumiam a condução deslocando o público entre uma posição e outra. Em outras ocasiões, os jogadores buscaram modos distintos de convidar o público com a ajuda de cacoetes como "vem", "por aqui, caros espectadores" ou até mesmo apontando a lanterna para o local para onde deviam se deslocar. Na corrente oposta a essa, no que diz respeito aos bons tratos, em uma das cenas, os jogadores expulsavam o público dizendo "Chispa! Sai daí!". Era curioso ouvir esse 
comando sucedido de uma cena de sexo, pois causava a impressão de que os jogadores haviam se dado conta de que estavam sendo observados. Nesse caso, ficava claro o papel de voyeur atribuído ao público.

Uma solução eficiente para os travellings do público foi a criação de um personagem chamado "Cão". Ele conduzia o público entregando sua coleira para algum espectador que ao invés de conduzi-lo era guiado pelo Cão. De certo modo, o posicionamento desse personagem perto do público, desde o início da encenação, criou um código facilmente apreendido pelos espectadores. Uma proposta que não chegou a ser concretizada, pois demandava mais radicalidade na lida com o público e dependia da sua presença para ser experimentada, foi a de estabelecer um tempo para o público percorrer um trecho do percurso sozinho, observando cenas instaladas nas máquinas. Esse momento aconteceria no início da encenação, momento importante para se estabelecer vínculos com o público. Por isso, optamos por deixar o Cão acompanhá-los, pois corríamos o risco de as pessoas se sentirem muito "livres" dentro da Hidráulica, ousando desbravar locais interditados ao público. A questão da segurança dentro do Laboratório foi insistentemente observada; não poderíamos responder por acidentes ocasionados no local.

A mudança de luz pode servir de recurso para atrair a atenção do público de um ponto a outro. Utilizamos esse recurso em uma cena em que o público estava sentado em banquinhos muito baixos e fáceis de manipular. Assim que havia a mudança na luz, os espectadores posicionavam seus banquinhos de frente para a nova cena. Entretanto, não ousamos deixar o público se deslocar em direção a uma luz, sem nenhuma coordenada explícita. É importante ressaltar que a prontidão dos atores em todos os casos de deslocamento do público é fundamental para o bom andamento da condução. Cada público reage de modo diferente do outro. Comportamentos inesperados podem ser detectados em situações semelhantes, por isso não há regras ou verdades quando o assunto é a atitude de um agrupamento casual de pessoas. Tamanha dificuldade se deveu ao fato dessa experimentação depender da reação dos espectadores em movimento. Mesmo que durante os ensaios a equipe técnica simulasse o comportamento do público, sua condução seria sempre improvisada. 


\section{Coleção dos Jogos do Olhar - Espaço + Corpo + Tempo}

Apresentamos abaixo três Jogos do Olhar propostos pelo Núcleo de Dramaturgia, cujo trabalho se voltou para a leitura da encenação. Em seguida, formalizamos como modalidade de jogo a busca de modos de condução do público em experimentos cênicos em espaços oficialmente não teatrais.

\section{Escrita do roteiro individual:}

Em tempo pré-determinado (15 minutos), escrever a seqüência de cenas das quais cada jogador participa. Mesmo em encenações mais convencionais, nem sempre os atores têm consciência da peça como um todo. No nosso caso, cada ator tinha um percurso muito peculiar dentro do espaço.

$$
\text { (protocolo de Katia Lazarini) }
$$

"Roteiro na mão, no bolso, na meia... um olho no todo e o outro no meu roteiro particular dentro da Hidráulica. Quais caminhos eu faço? Quando vou de uma cena a outra? Como? [...]

Qual a trajetória dessas personagens? A que me remete a seqüência de cenas que justapusemos? Eu sou Isaura? Quem é Isaura?"

\section{Leitura pós-dramática de roteiros individuais:}

Em seguida, os jogadores liam seus roteiros individuais, inclusive rubricas, indicações e lembretes no recorte de luz do retroprojetor. Além disso, realizavam suas partituras, paralelamente, respeitando a cronologia da encenação. Porém, isso não impedia a entrada de um ator no espaço do jogo para ler sua rubrica enquanto outro fazia uma partitura. Foi uma maneira divertida de mostrar aos "espectadores" (os próprios jogadores e a equipe técnica) a encenação e os bastidores da peça concomitantemente.

\section{Contar a peça:}

Em outro jogo, vivenciado um mês antes da estréia, foi proposto que os jogadores contassem a peça, como se fossem espectadores, para alguém que não a assistiu. Diante desse discurso, impossível de ser sintetizado, os jogadores se viram obrigados a descrever as cenas, o que ajudou na elaboração da leitura que tinham da própria encenação. 


\section{Travelling do público:}

Grande ponto de inflexão dentro do teatro em espaços não convencionais. $O$ público não permanece numa situação de contemplação passiva, mas é convidado a observar de pontos de vista inesperados. Entre um enquadramento e outro, o público precisa deslocar-se. Como conduzir o público? O deslocamento deve soar como pequena cena on the road e não como passagem. A dificuldade consiste em locomover o público, mantendo seu interesse pelo acontecimento cênico e a atenção aos obstáculos do lugar. No caso da Hidráulica, enquanto se deslocava, o público ainda observava, apropriava-se, interrogava o espaço. É preciso estar claro se o deslocamento deve interromper a observação da cena ou deve constituir-se uma proposta de jogo para o público caminhar de um ponto a outro.

\section{O papel do tempo na formatação de um coletivo}

"O tempo foi o meu mestre

Que me ensinou a curar

Passei três dias de bruço

Debaixo do humaitá

Quando eu me alevantei

Ô no tempo eu tou pra curar"

(Mestre Serrano, no CD Baião de Princesas,

da Casa Fanti Ashanti e a Barca)

Vivenciando a etapa do processo dedicada ao estudo do elemento Tempo na elaboração das cenas, muito se discutiu sobre a distribuição do tempo no decorrer dos ensaios. Traçando um paralelo entre a etapa do processo criativo e a configuração do Coletivo, destaco a importância do rigor no manejamento do tempo. Questões de ordem prática, de funcionamento e de organização, quase administrativas vieram à tona. A pesquisadora Anne Bogart discorre sobre o manuseamento do tempo em atividades coletivas: "Começar na hora. Começar e terminar as sessões de trabalho com pontualidade mostra um respeito pelos outros e acrescenta um sentido de ordem, o qual, paradoxalmente, permite maior complexidade e liberdade dentro do tempo designado" (BOGART e LANDAU, 2005, p. 21-22, tradução da autora) ${ }^{26}$.

${ }^{26}$ Do inglês: "Start on time. Beginning and ending work sessions with punctuality shows a respect for one another and adds a sense of order which, paradoxically, allows for more complexity and abandon inside the allotted time". 


\section{(Protocolo de Daniel Cordova)}

"Não existe um tempo ideal para um processo, o que existe é o que eu faço e como me organizo no tempo que tenho. Discutirei 30 minutos ou 2 horas? Demorarei 10 minutos ou 2 horas para arrumar o figurino, cenário, etc?"

No silêncio da Sala Branca (sala de ensaios), durante o estudo do tempo, aprendi que não adianta apressar o rio, ele corre sozinho. Nessa fase, o Coletivo viveu sua fase de maior precariedade; havia uma incerteza sobre a possibilidade de continuarmos a pesquisa na locação escolhida e três integrantes haviam saído do processo na mudança de ano. Apesar de abalados, participantes e coordenação mantiveram a pesquisa e vivenciaram um período de aprofundamento na proposta, paradoxalmente impulsionado por essa crise. A palavra de ordem era reorganizar, buscar uma nova configuração e encarar a realidade tal qual ela se apresentava. Não tínhamos o espaço escolhido como locação e éramos poucos. Então, o que era possível? O tempo já transcorrido, de vivência e pesquisa coletiva, contou pontos a favor do empenho que os jogadores tiveram e a vontade de concluir a criação iniciada levou-os a expressar suas prioridades e seus descontentamentos. Nesse momento, passamos por inúmeras conversas, acordos e discussões.

Vários ajustes nos relacionamentos foram propostos: precisavam de tempo para chegar até o ensaio, para o encontro, para a prosa, precisavam de um laboratório da chegada. O intervalo entre a chegada e o início do ensaio não é uma linha tênue, pois o fato de os participantes chegarem no horário combinado não garantia que o ensaio se iniciasse imediatamente. Eu não gostaria de assumir uma atitude vigilante, de quem sempre chega para acabar com a boa conversa e levar as pessoas ao trabalho. Esperava que a iniciativa de sair da conversa cotidiana para entrar no ambiente da pesquisa também viesse dos jogadores. Então, concordei com o seguinte acordo: precisavam de meia hora para a chegada, a conversa, a troca, a amizade. Ou seja, o ensaio começava meia hora depois do horário marcado, essa era a linha que separava a vida da prática, um intervalo de meia hora! Podemos observar no trecho de protocolo abaixo, reflexões sobre a utilização do tempo e a relevância das discussões travadas em roda:

(Protocolo de Anna Dulce) 
"O protocolo nos faz discutir e longas discussões são às vezes necessárias para a experiência democrática. $O$ conhecimento que se dá por meio da experiência é de fato mais demorado e mais difícil de ser assimilado. A humanidade é um experimento coletivo de milênios, o teatro é um experimento coletivo de milênios, mas a condição humana é uma experiência individual e é a partir desta matéria que se experimenta a coletividade, por isso é que com ela há de existir algum tipo de compreensão. Deve ter sido difícil para o Felipe ouvir aquilo que a gente falou sobre o protocolo dele no ensaio passado, mas também não é necessário fazer concessões, porque pode ser legal pro Felipe pegar tudo o que ele ouviu, embaralhar na cabeça e ir tirando dessas coisas pequenas conclusões temporárias. Afinal, uma experiência individual pode ser alimentada pela experiência coletiva. Nos Jogos do Olhar só sobraram os indivíduos que se sentem (temporariamente) alimentados. A humanidade, o teatro e o indivíduo andam não em círculos mas em espirais."

O estudo do Tempo inspirou mudanças significativas nos modos de produção, alternado também as formas dos protocolos. Experimentamos muitas maneiras de organizar nossas reflexões sobre a prática, desde encarregar uma pessoa por encontro de fazer o protocolo, que depois seria postado no blog do Coletivo, até ceder quinze minutos no final do encontro para todos escreverem suas impressões sobre a prática. Essas anotações poderiam ser mais desenvolvidas em momentos posteriores ao ensaio, ou não. A última alternativa descrita servia como uma avaliação da autonomia do grupo no que concerne à necessidade da reflexão crítica a partir das experiências vividas.

Outra proposta, inspirada pelas aulas da pós-graduação da professora Ingrid Koudela, foi a prática de realizar protocolos coletivos. Não que eles fossem escritos coletivamente, mas todos preparavam seus protocolos individuais a cada encontro, buscando sintetizar os aprendizados da aula anterior e criar conexões com as leituras e pesquisas individuais. No momento da leitura dos protocolos, cada jogador selecionava trechos interessantes do próprio protocolo para compartilhar com o grupo. O "coletivo" da proposta se fazia no momento de tecer os comentários, pois a seleção do trecho dependia das proposições dos outros. Nessa proposta, havia também a possibilidade dos protocolos sugerirem a continuidade do estudo, muitas vezes assuntos levantados nos protocolos eram desenvolvidos na aula. O protocolo funcionava como um propulsor da aprendizagem. Diante dessa rica experiência nas aulas de pós-graduação, sugeri ao Coletivo - Jogos do Olhar que aditássemos essa 
estrutura para protocolar nossas discussões. No entanto, diferente do que ocorria nas aulas da professora Ingrid, nas quais todos os alunos escreviam e acabavam lendo todo o protocolo, no nosso contexto, a tendência à fragmentação foi exagerada e começou a incomodar o grupo.

(protocolo de Daniel Cordova)

"Essa leitura videoclíptica dos protocolos está me incomodando. Por que não aproveitar esse espaço de escrita para realmente se dedicar a escrever algo com consistência, bem articulado, saindo desse costume cotidiano de escrever em tópicos, flechas. Parece um exercício jogado fora. Os pensamentos são pontas de icebergs, ou o gelo fino do Bauman, que logo se quebra, ou os objetos de Calicó que não enxergam desenvolvimento no tempo."

Na ocasião da reestruturação do Coletivo, impulsionados pelo estudo do Tempo, os jogadores sugeriram que voltássemos à estrutura mais convencional de protocolos realizados em um caderno coletivo. A última fase de aproximação dos procedimentos cinematográficos e de formalização da encenação foi marcada pela rotatividade de um caderno de capa verde (bem no estilo "Hidráulica" - cheia de tubos verdes), do tipo brochura, pautado. Depois de passar por propostas totalmente conectadas com o tempo atual, realizando protocolos veiculados em um blog, cujas informações permanecem acessíveis pela internet, o Coletivo propõe uma volta ao caderno escolar. Essa escolha mostrou-se coerente com o momento do processo, embora eu não a tivesse previsto anteriormente.

Foi bastante rico testar todas essas formas de pensamento e debate sobre o processo de criação e aprendizagem, as quais se revelaram como pretextos para análise e não podem ser consideradas receitas prontas e certas. O que pudemos reter desse passeio por muitas formas de protocolar foi a importância de se ouvir o grupo de jogadores com o qual se compartilha a aprendizagem e a criação. Como coordenadora desse processo, aprendi a passear por diversas formas de discussão, sem temer as mudanças, experimentando novas propostas como resposta às insatisfações com os procedimentos escolhidos.

Na função de professor-encenador, somos testados cotidianamente sobre o nível de controle no que se refere aos encaminhamentos propostos. De formas diferentes, cada jogador investiga o quanto o coordenador é flexível na 
escuta do Coletivo e o quanto está interessado em manter suas convicções. Geralmente, os procedimentos adotados são questionados porque o grupo não sente que eles correspondam às necessidades do processo que se vive. Muitas vezes, no entanto, o descontentamento com o procedimento adotado, expressado pelo jogador, é um descontentamento consigo mesmo: seja pelo fato de não ter cumprido o combinado, seja por não se sentir estimulado para refletir, seja por não ter aprendido a avaliar criticamente em nenhum outro contexto de aprendizagem. Muitas pessoas jamais tiveram suas opiniões requisitadas em momentos de avaliação. Portanto, cabe ao mestre-encenador ouvir o grupo não só com os ouvidos e não só na hora da manifestação do descontentamento, pois entendemos o outro também nas brechas das atividades "sérias", nos intervalos, nas atitudes mais cotidianas. Aprendi a devolver o descontentamento para o grupo e avaliar se ele era comum ou particular. Aprendi a não responder sozinha pela falta de interesse do outro, convidando a todos para refletir sobre os procedimentos escolhidos. Diante de todas as incertezas que envolvem processos artístico-pedagógicos, pode-se acertar parando para conversar e pode-se acertar escolhendo não prosseguir com a discussão.

Por isso é tão importante a clareza nos acordos, para que a análise e a escolha do procedimento estejam sedimentadas sobre as regras acordadas coletivamente. Algumas vezes, concordava em mudar a dinâmica do protocolo para que o Coletivo percebesse que o problema não estava no procedimento e sim no modo de proceder. Outras vezes, fiquei surpresa ao perceber que uma escolha que para mim era pouco relevante, suscitava reflexões mais profundas do que aquelas baseadas em parâmetros os quais julgava importantes. Dessa experiência, noto que a função do professor-pedagogo é descrever uma trajetória nítida, porém flexível e dinâmica, sujeita a atalhos, corridas desenfreadas e pausas, às vezes longas, para conversar e aprender a pensar junto.

Outro aspecto que considero relevante destacar, uma das premissas dessa pesquisa, é a opção por não distinguir processo criativo de processo de aprendizagem. Ao conduzir uma pesquisa, cujo objeto de estudo é artístico, não posso me colocar senão como artista. Ao mesmo tempo, considero o 
artista um indagador, um curioso, um sedento por descobrir o que desconhece. Essa afirmativa não diminui os saberes adquiridos ao longo da experiência, mas não redime nenhum artista de se colocar como aprendiz do próprio processo de criação. Quem não tem o que o aprender, não tem o que pesquisar. Por isso, confundo, propositalmente, processo criativo e processo de aprendizagem. Tanto a arte quanto a aprendizagem caminham numa mesma via, mesmo que as aprendizagens tenham teores diferentes. Provavelmente, nenhum dos participantes do Coletivo tenha investigado como eu, a dinâmica de ser flexível ao definir caminhos para a criação, simplesmente pelo fato de eu ter sido a pessoa a ocupar a função de professora-encenadora. Mesmo que muitos deles observassem minhas atitudes, interessados também em assumir essa função em outros contextos, suas aprendizagens ocorreram em outras instâncias. Poderia citar a aprendizagem dos jogadores, mas escolho citar a minha, nesse momento, como forma de me colocar também como sujeito da aprendizagem.

\begin{abstract}
Meyerhold sempre liga encenação e pedagogia: cada espetáculo propõe tanto aos atores quanto ao encenador problemas diferentes, gera um programa de trabalho particular, considerado como um elemento capaz de fazer progredir a "ciência da cena". (PICONVALLIN, 1987, p. 109, tradução da autora) $)^{27}$
\end{abstract}

Não consigo separar as funções de professora e encenadora: como poderia agir ora como professora, ora como encenadora? Seria uma mudança de atitude, de foco de interesse, de trato com os jogadores? A dificuldade em assumir a unidade nessas duas funções me parece associada a um conceito de professor excessivamente didático, explicativo, e de um encenador incompreendido, com dificuldades de comunicação com os atores e popular pelas grosserias e maus tratos. De outro modo, poderíamos dizer que o encenador está interessado no produto artístico e o professor no processo de aprendizagem. No entanto, existe uma leva de encenadores bastante preocupados com o processo de formação de seus atores como sujeitos de sua arte, sem desconsiderar as qualidades artísticas de seus produtos. Tais

\footnotetext{
${ }^{27}$ Do fracês: "Meyerhold lie toujours davantage mise en scène et pédagogie: chaque spectacle pose aux acteurs comme au metteur en scène des problèmes differents, génère un programme de travail particulier, se voit consideré comme un élément capable de faire progresser la 'science de la scène'". 
encenadores consideram-se igualmente professores e, freqüentemente, valorizam o processo em detrimento do produto, pois vivenciam processos criativos longos e preocupam-se também com a formação da platéia e não somente com o número de produções que disponibilizam no mercado por ano.

Com Grotowski e Barba é impossível distinguir o encenador do pedagogo. [...] A osmose é total entre os processos de treinamento $e$ os processos de criação. O encenador enquanto tal é pedagogo. Não há vai e vem ou tensão entre as duas funções, circulação entre os dois papéis. A encenação em sua essência está fundada na relação pedagógica. Mais: essa relação pedagógica define de certo modo o próprio ato de fazer teatro, tanto quanto a preparação para esse ato. E a noção de 'teatro de grupo' cristaliza essa idéia de teatro que faz da situação pedagógica seu núcleo. (BORIE, 1987, p.128, tradução da autora $)^{28}$

Nesse aspecto, vale ressaltar que a atitude do Coletivo - Jogos do Olhar reafirma a voz da professora Monique Borie, citada acima. Mesmo considerando-se um coletivo e não um grupo, esse agrupamento tomou para si a função pedagógica no workshop proposto pelos próprios jogadores com o objetivo de agregar novos participantes na ocasião da saída de alguns integrantes na mudança de ano, momento de crise ao qual nos referimos acima. Era uma maneira de convidar novos jogadores para o Coletivo, conhecendo-os minimamente em jogo e apresentando de forma breve as etapas da criação vivenciadas até então. Discutimos bastante sobre como fazer os convites e como integrar novas pessoas ao Coletivo. Depois de muito raciocinar, concluímos que os novos integrantes precisavam receber treinamento similar ao recebido pelo Coletivo inicial e deveriam atuar criativamente na composição da encenação.

Assim, espalhamos cartazes na Cidade Unversitária, convidando pessoas interessadas para o workshop, que se destinava a quem gostava de cinema e

\footnotetext{
${ }^{28}$ Do francês: "Avec Grotowski et Barba il est impossible de distinguer le metteur en scène du pédagogue. [...] L'osmose est totale entre les processus d'entraînement et les processus de création. Le metteur en scène en tant que tel est pédagogue. II n'y a pas de va-et-vient ou de tension entre deux fonctions, de circulation entre deux rôles. La mise en scène dans son essence est fondée sur la relation pédagogique. Plus: cette relation pédagogique définit en quelque sorte l'acte même de faire du théâtre tout autant que la préparation à cet acte. Et la notion de 'théâtre de group' cristalise cette idée d'un théâtre qui fait de la situation pédagogique son noyau."
} 
queria fazer teatro. Para a inscrição era solicitada uma carta (no mínimo uma frase!) de interesse, que poderia ser enviada por e-mail. Doze pessoas se inscreveram; entretanto nem todos participaram de todos os dias de atividades. Apesar disso, pudemos perceber quem eram as pessoas que melhor se adaptavam à proposta apresentada. Seis pessoas foram convidadas e quatro aceitaram o convite, mas apenas três puderam ingressar no Coletivo.

Entre os jogadores do Coletivo, cinco se interessaram em conduzir os encontros do workshop. Juntos, preparamos os ensaios e nos dividimos em duplas para as conduções. Esse foi o primeiro "evento" realizado por todos os integrantes. O workshop foi dividido em três dias de atividades: um teórico e dois práticos. No primeiro dia, eu apresentei o histórico da pesquisa e os procedimentos cinematográficos aos quais nos remeteríamos nos exercícios práticos dos dias seguintes. E em seguida, analisamos um filme coletivamente, apontando os procedimentos destacados anteriormente. Os encontros práticos ocorreram na Faculdade de Arquitetura e Urbanismo da USP, local explorado pelo Coletivo na ocasião da peregrinação em busca de uma locação.

Paula Bellaguarda e Daniel Cordova conduziram o primeiro dia de trabalho, composto por exercícios de atenção e apresentação dos jogadores em roda (todos já utilizados no nosso treinamento). Conduziram ainda a observação do espaço para que os jogadores o experimentassem de fato e tivessem instrumentos para selecionar "recortes" do lugar, para depois produzirem fotografias (imagens fixas). Os condutores estavam um pouco inseguros; como eu gostaria de observar a condução deles sem intervir, não consegui ajudá-los muito. Foi uma oportunidade de diagnosticar a apreensão que tinham em relação aos jogos. Notei que as modalidades que estavam bem incorporadas eram justamente aquelas repetidas em todos os espaços experimentados. Também foi importante a troca de papéis, pois quando os jogadores ocupam o lugar de quem conduz, têm que lidar com dificuldads imprevistas, como por exemplo: como passar as instruções que antecedem o jogo?

$$
\text { (protocolo de Paula Bellaguarda) }
$$

"Poxa vida, como é importante este registro e a retomada dele - bobo jeito de dizer, mas vi o quanto se pode retomar uma experiência vivida, mas não refletida, o que dela apreendeu. 
Bonito ver o que eu senti pelos olhos dos outros e aprender agora com eles o que já havia vivido."

No segundo dia, Daniel Cordova e Adriane Escher se encarregaram da condução e propuseram jogos de atenção e prontidão, seguidos de proposta para disponibilizar as articulações do corpo. Em seguida, exercícios de composição de figuras geométricas e de composição de coros, com um corifeu se destacando foram realizados. Depois, retomaram os recortes de espaço destacados no dia anterior, criaram novas fotografias, escolheram três delas e inventaram ligações entre as fotos. Dessa maneira, revelaram as primeiras etapas da composição das cenas, tal qual desenvolvemos na Hidráulica. A dupla de condutores desse dia estava mais confiante. Do meu lado também havia mais tranqüilidade, uma vez que passei a contribuir para o desenvolvimento das propostas quando julgava necessário.

O retorno do grupo foi muito positivo. Alguns participantes haviam assistido aos ensaios abertos na Hidráulica e comentaram que haviam compreendido a proposta de pensar a cena como uma imagem, fato identificável na encenação. Perceberam o cuidado do processo com a escolha do ponto de vista do público e a riqueza de possibilidades de ressignificação de um espaço, ao recortá-lo.

As mesmas modalidades de jogos desenvolvidas nesse workshop também foram propostas a um grupo jovens do C.E.U. Perus, em outubro de 2007. O Coletivo - Jogos do Olhar foi convidado para uma demonstração prática da pesquisa nesse equipamento da Prefeitura de São Paulo ${ }^{29}$. Nessa ocasião, conduzi as propostas de exploração do espaço, sendo que os integrantes do Coletivo participaram como jogadores juntamente com os jovens do C.E.U.. Utilizarei os registros fotográficos dessa experiência como exemplo da pesquisa desenvolvida com outros agrupamentos em diferentes espaços (fotos no Anexo III).

${ }^{29} \mathrm{O}$ convite partiu de Paula Klein (mestranda da ECA/USP e artista-orientadora do Projeto Vocacional) para a participação na Mostra de Teatro do C.E.U. Perus (20/10/2007). 
1. Cartaz do Workshop - Jogos do Olhar, foto e arte de Renata Velguim

2. Demonstração Prática dos Jogos do Olhar no C.E.U. Perus, fotos de Renata Velguim 


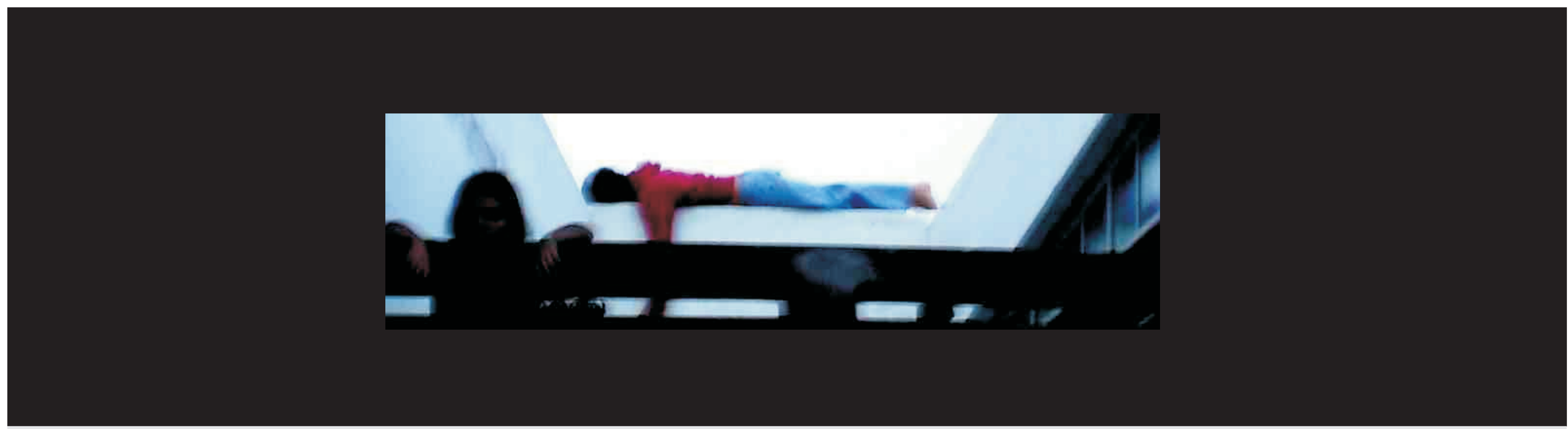

workshop JOGOS DO OLHAR - apresentação dos procedimentoscinematográfic os para a composição da cena teatral (para interessa dos em cinema que querem fazer tea tro) 

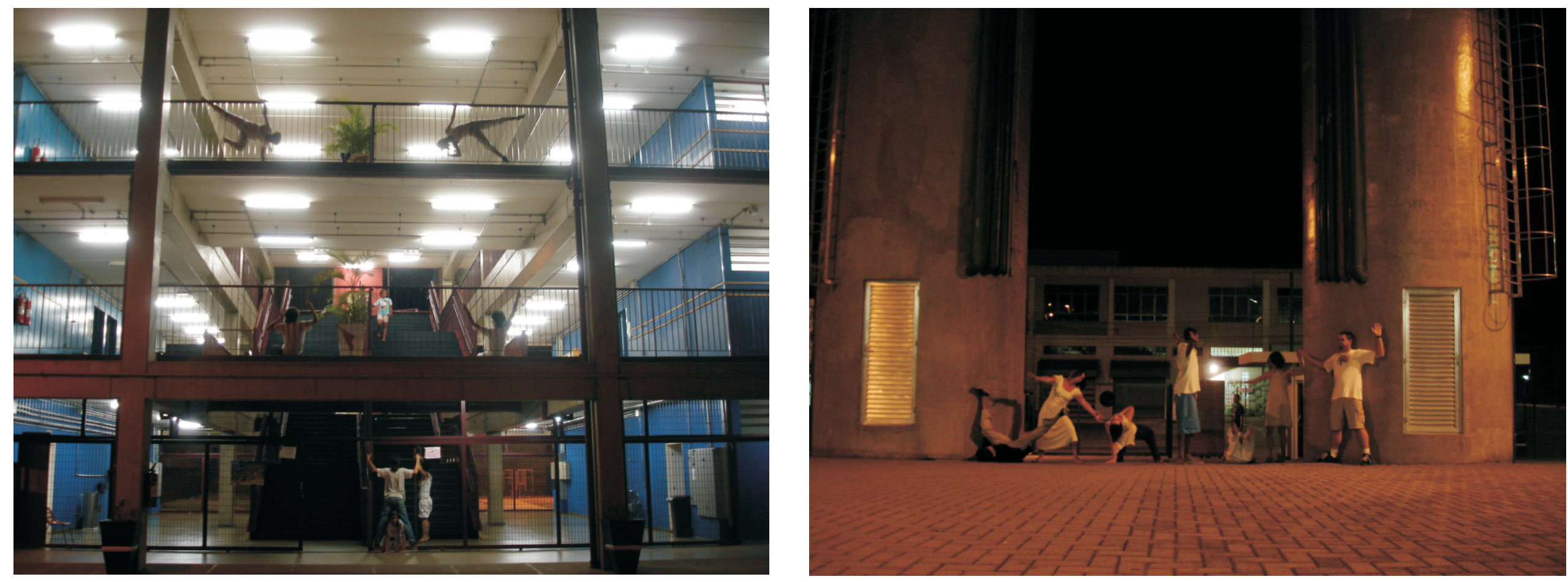

CEU
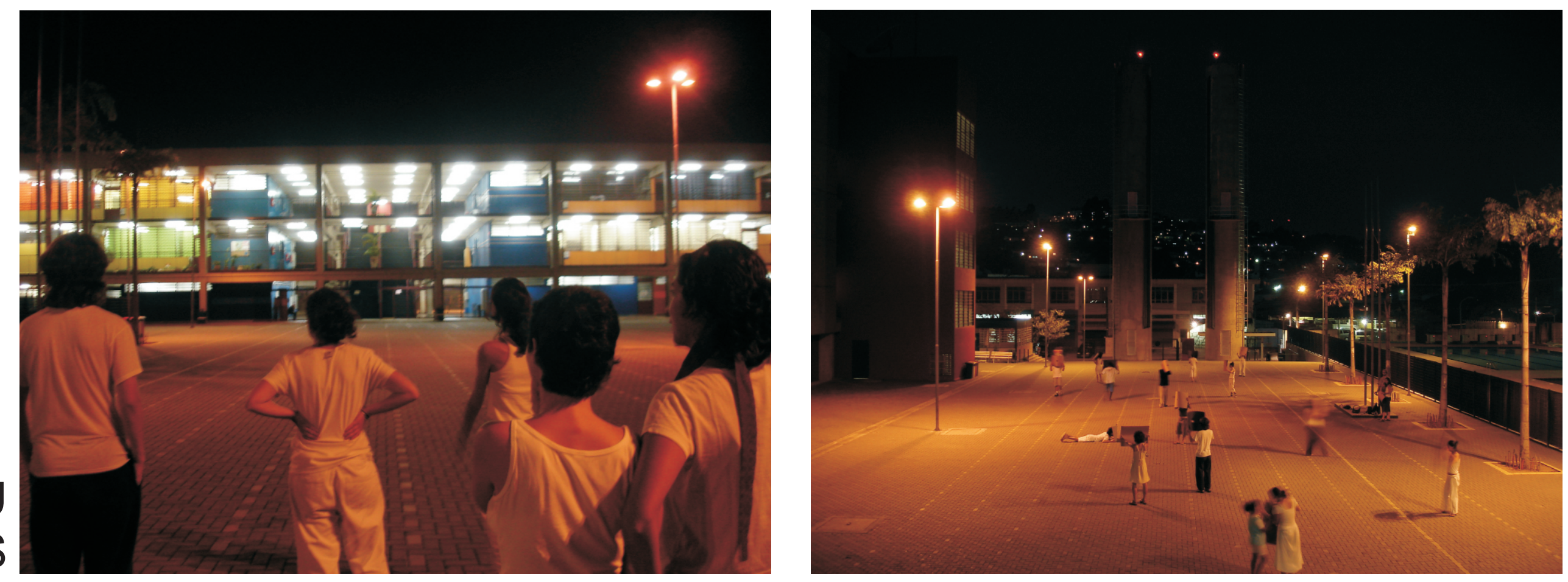


\section{Capítulo 4: Compor a cena teatral de modo cinematográfico}

"A imaginação do espectador trabalha sob o impacto de duas impressões, uma visual e outra auditiva" Béatrice Picon-Vallin

Este capítulo apresentará uma proposta de composição teatral que se aproxima de um modo de compor cinematográfico. Isso não significa que a composição cinematográfica aconteça dessa forma. No cinema, a estruturação dos elementos da cena acontece em dois níveis: na filmagem e na montagem. Ao propor um movimento de câmera ou um enquadramento, referimo-nos ao momento da filmagem. Ao estabelecer conexões entre dois planos ou entre a faixa de imagem e a faixa de som, referimo-nos ao momento da montagem. Fazer cinema e assistir a cinema são duas experiências completamente distintas. A proposição apresentada aqui parte de alguém que não faz cinema, mas que enxerga no cinema um campo fértil para o diálogo entre as linguagens que se prestam a escrever o visível. Compor a cena teatral de modo cinematográfico poderia ser interpretado das maneiras mais diversas possíveis. Entretanto o recorte pontual efetuado nos ajuda a estabelecer balizas para buscar correspondências entre as duas linguagens. Exemplo da associação do cinema com um teatro com o qual essa pesquisa não se identifica é a citação abaixo (LEHMANN, 2007, p. 313), em que o autor descarta a possibilidade de encontrar no cinema ferramentas para a composição de um teatro pósdramático ou de relações dramáticas reinventadas, de acordo com a perspectiva presente entre os franceses hoje.

Tal teatro de uma contemplação desacelerada, mas próxima da contemplação pictórica, se afasta ainda mais de seu irmão mais popular, o cinema, na medida em que não partilha sua inclinação para a fabulação, substituindo a linha de tempo de uma trama pela experiência de um tempo teatral global que se pauta pelo ritmo. É somente por via da imersão nesse ritmo cênico que se chega à percepção de narrações 'conteudísticas' residuais - freqüentemente fragmentadas - possíveis histórias, temas, associações.

Observamos algumas tendências no teatro contemporâneo que gostaríamos de salientar, tais como: a diminuição da relevância da fábula e dos 
personagens, o excesso ou a escassez de ações e falas e a manipulação explícita dos elementos cênicos no que diz respeito à sua materialidade. Paralelamente, identificamos na estrutura de alguns fragmentos de filmes, a gramática cinematográfica sendo utilizada independentemente de uma função utilitária, de comunicação ou justificativa do enredo. Essa aplicação dos recursos fílmicos pode ser percebida como responsável pela inscrição na obra de certos efeitos de desconstrução do discurso, enfatizando a falha no sistema, a impossibilidade de comunicação. Não considero esse modo de compor a cena teatral um modelo, apenas uma hipótese, uma proposta de composição inspirada nos fragmentos cinematográficos observados. É importante destacar o estudo de partes dos filmes, de fragmentos, pois somente com esse corte interceptando-o verticalmente, conseguimos estabelecer tais conexões com o teatro que nos interessa.

De outro modo, se observássemos os filmes como um todo, constataríamos a presença de uma narrativa mais ou menos linear, pautada em uma fábula, com personagens bem definidos, cujo modo de se apresentar explicita a presença da montagem, da câmera e do corte. A primeira constatação, portanto, não nos interessa no que se refere à composição teatral investigada; a segunda constatação, sobre o modo de apresentar a narrativa, refere-se ao ponto com o qual nos identificamos e sobre o qual nos detivemos na análise dos fragmentos fílmicos. O teatro ao qual chegamos é uma possibilidade de teatro a partir desse recorte do cinema, ou antes, posterior às experimentações cênicas em torno desse cinema.

O que está em jogo nesse estudo quando falamos em um modo cinematográfico de composição é a "incorporação de implicações estéticas do olhar fílmico" (PAVIS, 2005, p.43). Patrice Pavis fala em implicações no modo de olhar: de que forma um olhar acostumado com cortes, fragmentação do corpo e montagem compõe sua escritura teatral? O exemplo abaixo retrata muito bem nosso foco de interesse na interação entre teatro e cinema.

Pina Bausch, e com ela boa parte da dança contemporânea dita pósmoderna, utiliza processos de composição coreográfica que seriam esperados mais na estética do filme ou do vídeo: fragmentação do gesto, repetição de uma seqüência, efeito de close e de focalização, fades, olhares para a câmera, elipse narrativa, montagem em câmera 
rápida. Como se a maneira de coreografar passasse por um olhar mediado pela câmera ou a mesa de montagem do cinema ou vídeo. (Ibidem, p. 44)

Anne Bogart entende que estudar composição seja tomar emprestado princípios de outras disciplinas para traduzi-los para o teatro. Para ela, podemse buscar procedimentos no teatro que sejam equivalentes ao ritmo na música e ao corte no filme.

Composição é um método para estar em diálogo com outras formas de arte, pois toma emprestado e reflete outras artes. No trabalho de Composição, estudamos e usamos princípios de outras disciplinas traduzidos para o palco. Por exemplo, emprestando da música, podemos perguntar o que é o ritmo de um momento [...]. Ou nós pensaremos em um filme: "como encenar um close? E estabelecer um corte? Uma montagem?" E nós perguntaremos: "O que é o equivalente no teatro?" (BOGART e LANDAU, 2005, p. 13, tradução da autora $)^{30}$

Nosso modo de compor opera por meio da sobreposição de camadas: estabelecemos o recorte espacial (a partir do ponto de vista do público), preenchemos de figuras (corpos) e dotamos esses corpos de movimento. Poderíamos falar em assemblage (mistura) para nos referir à combinação de uma superfície (espaço) e suas figuras (corpos), dispostas e percebidas em silêncio. Essa maneira de escrever a cena dialoga com os princípios desenvolvidos por Bob Wilson: a criação parte do desenho da imagem sobre um suporte espacial e não sobre um suporte papel, uma superfície tridimensional e não bidimensional. $\mathrm{O}$ encenador norte-americano entende $\mathrm{O}$ teatro como arquitetura, como livro visual, onde o tempo pode ser esculpido. Essa escolha apóia-se na des-hierarquização dos elementos constitutivos da cena, enfatizando, sobretudo, a mudança do estatuto do texto na cena. Desse modo, no nosso caso, a temática da obra nasce da sobreposição de elementos, dispostos em camadas e articulados segundo relações espaçotemporais. Ao invés de a imagem ser tomada como pano de fundo ou

\footnotetext{
${ }^{30}$ Do inglês:"Composition is a method for being in dialogue with other art forms, as it borrows from and reflects the other arts. In Composition work, we study and use principles from other disciplines translated for the stage. For example, borrowing from music, we might ask what the rhythm of a moment is (...). Or we'll think about film: 'How do we stage a close-up? An establishing shot? A montage?' And we'll ask: 'What is the equivalent in the theater?' "
} 
ilustração dos textos, ela se apresenta inteiramente para o desfrute da visão, liberando a audição para uma percepção paralela e simultânea. A citação abaixo apresenta a montagem vertical proposta por Eisenstein. O modo de composição cinematográfico sugerido nesse capítulo pode ser entendido como um desdobramento desse tipo de montagem.

[...] As formas mais complexas de sobreposição de palavra e imagem encontraram seus melhores exemplos no cinema moderno, mas a questão foi explicitamente formulada, pela primeira vez, num artigo de S. M. Eisenstein, escrito em 1932 [...].

[...] a formulação do cineasta russo, embora apoiada numa situação particular, abriu espaço para formas mais radicais de combinação assíncrona de palavra e imagem, formas de montagem vertical que o cinema moderno, depois de 1960, veio a explorar (como em Alain Resnais, Jean-Luc Godard, Bernardo Bertolucci, Robert Bresson ou Glauber Rocha). Vale lembrar que não basta a presença de uma locução a comentar as imagens para que tenhamos o verticalismo proposto por Eisenstein - é preciso ter um efeito de simultaneidade que preserve, ao mesmo tempo, a disjunção entre som e imagem, seu entrechoque, estranhamento [...]. (XAVIER, 1997, p. 128)

O fundamento de base desse modo de composição é a montagem, que pode ser considerada uma herança cinematográfica, apesar de também constituir-se recurso próprio à literatura. Estabelecendo um parêntese, podemos tecer algumas considerações sobre as influências da literatura e do cinema na construção do imaginário de uma época e, conseqüentemente, as alterações percebidas na composição da cena teatral. Ao comparar a produção teatral atual com a produção de um momento anterior a este, nota-se que o paradigma do século XIX era a literatura, pois o teatro era influenciado por questões literárias: a narração, a representação, a figuração e a linearidade. Em contrapartida, as mudanças observadas no teatro recente (realizado nos últimos trinta anos) apontam para uma multiplicidade de informações que aproximam o teatro mais de um objeto cinético (Lehmann, 2007, p. 313) do que de um objeto literário. Sem pretender unificar esses teatros em poucas características que ignorem suas particularidades, gostaria de chamar a atenção para a mudança do estatuto do texto e, em conseqüência, dos demais elementos da cena (corpos, espaço, tempo) na atualidade. 
Não pretendo envolver literatura e cinema em uma atmosfera de confrontação. Embora o cinema se utilize de textos e a literatura cultive a produção de imagens mentais, suas materialidades são diferentes: a palavra e a imagem. O cinema é uma linguagem inicialmente imagética, mesmo que tenha se apropriado posteriormente da palavra, dos ruídos e da música. Não questiono o papel primordial da literatura na construção do imaginário humano, entretanto considero que essa construção sofre fortes influências do cinema e das novas tecnologias da imagem. E, em última instância, o que está em jogo não é a escolha de uma das linguagens como meio de expressão. Prova disso é o comentário que Christian Metz faz da genialidade de Orson Welles na manipulação do choque, que poderia recorrer a uma continuidade de câmera tão envolvente quanto uma frase de Proust (METZ, 2004).

A seguir discutiremos o modo de organização da escritura teatral, tal qual desenvolvemos na experimentação prática (ISAURA S/A + 1 Experimento Hidráulico), no que concerne à sobreposição do texto, do som e da iluminação. Ao discutir texto e som, tratamos de voz, ruídos e músicas produzidos pelos atores, pelo espaço e registrados em áudio. Por fim, e de forma conclusiva, apresentaremos nossas considerações finais sobre as relações entre a composição da encenação e a formatação do Coletivo - Jogos do Olhar.

\section{Textos: ditos, ouvidos e vistos}

"Agora não se fala mais. Toda palavra guarda uma cilada.

E qualquer gesto é o fim.

Do seu início."

Torquato Neto

Ao estudar o elemento Texto na cena contemporânea e, conseqüentemente, na maneira como nos apropriamos do texto como modalidade de Jogo do Olhar, investigamos o lugar e a função do texto na dramaturgia da imagem.

Em linhas gerais, tomando o exemplo de alguns encenadores contemporâneos, podemos elencar algumas tendências da cena teatral com a qual nos identificamos. A profusão de imagens notada, por exemplo, no teatro de Bob Wilson, revela a primazia do fenômeno cênico em detrimento da 
narração. O efeito de imagem conquistado pela relação do ator com o espaço se sobrepõe à individualidade de sua figura, a qual não chega nem mesmo a ser considerada um personagem. Ao espectador é solicitada uma mudança de atitude, pois não compreenderá imediatamente todos os signos apresentados na cena e, provavelmente, não assimilará tudo. A urgência não está na compreensão de uma mensagem, mas no contato com o objeto artístico. Lehmann fala em dois fatores concomitantes: o significado suspenso e o parcelamento da percepção (LEHMANN, 2007, p. 145). Convida-se o público a buscar um estado mais contemplativo e menos interpretativo. O exemplo da obra de Bob Wilson vale mais uma vez para demonstrar um teatro que cria um tempo para o olhar.

Ninguém é capaz de apreender tudo o que se passa em um espetáculo de dança de William Forsythe e de Saburo Teshigawara. Em certas representações o acontecimento visível no palco é cercado e complementado por uma segunda realidade impossível de ignorar, composta de ruídos, música, vozes e estruturas barulhentas de todo tipo, de modo que é preciso falar da existência simultânea de um segundo "palco auditivo" (Helene Varapoulou), como no caso das montagens da Orestéia e de Júlio César pela Societas Raffaello Sanzio. (Ibidem, p. 146, grifos do autor).

A ação e a fábula perdem lugar e importância. Entre a situação inicial e a final, não há progressão da ação nem transformação. Em contrapartida, notase um jogo desmedido no que se refere à utilização da palavra: ou ela aparece excessivamente ou é praticamente escassa. No âmbito desse teatro das imagens, o estatuto da palavra na cena revela-se na presença de monólogos e coralidades; o diálogo é cada vez mais raro, levando-nos a refletir sobre os níveis de interlocução na contemporaneidade. Segundo o professor JeanPierre Ryngaert, o diálogo tem recebido "infiltrações" de seqüências narrativas, as quais Peter Szondi denomina de sujeito épico, enquanto o professor prefere falar de sujeito rapsódico ou pulsão rapsódica. O conceito de narrador-rapsodo, bastante desenvolvido por Jean-Pierre Sarrazac, remonta a uma figura que toma partido, testemunha a ação, ora de modo épico, ora de modo dramático.

Um diálogo que costura junto (rhaptein em grego significa "coser") modos poéticos diferentes, até mesmo refratários uns aos outros (modo lírico, épico, dramático, argumentativo). Sendo que o rapsodo 
é esse costurador-descosturador. Um novo "partilhamento de vozes" se instaura onde a voz - que só se exprime através das didascálias, que intervém no discurso dos personagens - e o gesto do rapsodo o da composição, da fragmentação, da montagem reivindicada - se intercalam entre as vozes e os gestos dos personagens. (RYNGAERT, 2005, p.14-15, tradução da autora) ${ }^{31}$

Diferente do diálogo padrão, clássico, que opera como um jogo de pingue-pongue (um fala e o outro responde), focado em um só tema, cuja função é fazer avançar a ação, o diálogo ao qual o professor se refere é híbrido. A voz do autor aparece de maneira mais ou menos explícita e passeia por diversos temas, sem preocupar-se em informar o espectador de tudo que diz e sem compromisso com a ação. Segundo Ryngaert, o diálogo contemporâneo sofre influências da conversa, desprovida de projeto e de intenção, carregada de informações implícitas e sem poder de modificar a ação. Ou seja, ao final de uma conversa, nada muda no estado dos enunciadores. $O$ professou citou um exemplo muito interessante ao discutir a relação entre fala e situação. De acordo com o ele, o cineasta francês Jean-Luc Godard teria dito que era extremamente tedioso falar de amor na cama e de política no Congresso Nacional. Ao passo que falar de política na cama e de amor no Congresso Nacional seria muito mais interessante. A anedota serve muito bem para explicitar a desincronia entre ação e fala na atual escritura do visível, já que o autor do exemplo me dá liberdade para englobar também o cinema nessa afirmativa.

Após essas observações mais abrangentes sobre o texto na cena, voltaremos ao nosso objeto de estudo. Não sem antes fazer algumas ressalvas. Sabemos que a cena contemporânea não obedece regras. $\mathrm{Na}$ atualidade, formas distintas de escrituras teatrais convivem, por isso não podemos falar em regras gerais. A resposta a esse teatro sem ação nem personagem, pode acontecer de duas formas. Em certa vertente de pesquisa, pode ocorrer o fortalecimento do texto, que predomina sobre os demais

\footnotetext{
${ }^{31}$ Do francês: "Un dialogue qui coud ensemble (rhaptein en grec signifie 'coudre') des modes poétiques différents voire réfractaires les uns aux autres (modes lyrique, épique, dramatique, argumentatif). Le rhapsode étant ce couseur-découseur. Un nouveau 'partage de voix' s'instaure où la voix - qui ne s'exprime pas qu'à travers les didascalies, qui s'immisce dans les discours des personnages - et le geste du rhapsode - celui de la composition, de la fragmentation, du montage revendiqué - s'intercalent entre les voix et les gestes des personnages". 
elementos da cena. De outro modo, o teatro pode estar apoiado na composição imagética, multitemática, em que prevalece a escassez textual. Este é o recorte teatral ao qual nos referimos.

No experimento cênico que realizamos na Hidráulica, os textos vieram de muitas fontes distintas: roteiros dos filmes estudados, textos teóricos referentes à essa pesquisa acadêmica e trechos literários trazidos pelos jogadores como complemento aos protocolos. O roteiro do experimento teve sua versão final concluída apenas no final da temporada de apresentações. Proveniente de uma criação coletiva, não se sustenta sem a encenação, nem servirá para outros grupos em uma montagem futura, portanto esse roteiro não pode ser considerado dramaturgia. No entanto, ao analisá-lo podemos identificar pontos de aproximação com as discussões presentes na dramaturgia atual.

Os textos presentes no roteiro, no ato de sua emissão, podiam ser ditos (por um ou mais emissores), ouvidos (pois os emissores não estavam presentes) ou lidos (no caso de textos apresentados graficamente). Desse modo, os textos ditos e ouvidos serão analisados de acordo com as seguintes características: número de emissores e a presença ou a ausência dos emissores no ato da emissão. A matéria textual chega a níveis de grande fragmentação, resultando em estilhaços de texto. Aproximamos esses fragmentos, palavras mais próximas dos sons do que de elaborações frasais, das sonoridades produzidas pelo corpo. Por isso, trataremos das informações sonoras, provenientes dos corpos, do espaço e de músicas cantadas e gravadas, presentes no roteiro, apenas no item seguinte.

Quanto ao número de emissores dos textos da encenação, pode-se dizer que, proporcionalmente, o número de monólogos e formas corais é bastante superior ao número de diálogos. Considero esse dado sintomático, um sinal dos tempos: solilóquios e coralidades discordantes em detrimento do diálogo. Como não vêm de personagens bem delineados, os textos ressoam como sussuros anônimos ou vozes diluídas numa coletividade que representa menos a união de um grupo, uma massa imbuída de princípios comuns, do que um aglomerado de individualidades singulares. Não trataremos de todos os textos do roteiro, apenas de alguns que servirão para exemplificar o trabalho 
desenvolvido. Quanto aos monólogos, selecionamos dois, um excerto de texto teórico pesquisado e outro pinçado de um dos filmes selecionados.

[...] a preparação para o movimento se inicia antes da nossa decisão de mover algo. Esta preparação se associa à atividade cerebral e forma o potencial de prontidão - espécie de onda elétrica discreta que pode ser medida acima dos lobos frontais, e que começa um terço de segundo antes de um movimento ser observado. [...] Há quem ligue o estado de prontidão às narrativas subconscientes ou ao narrador dentro da nossa cabeça: nossos olhos seriam câmeras de televisão que projetam as suas imagens para dentro do nosso cérebro. Quem assiste às imagens lá dentro? Um narrador, é claro, uma espécie de miniatura de nós mesmos. Um homúnculo embutido no nosso cérebro que fala para nós com uma voz que apenas nós ouvimos. [...] Há que desconfiar desse modelo de miniatura de eus de plantão nas mentes humanas. (KATZ, 2005, p.58-59)

O texto em que Helena Katz cita os estudos de um neurofisiologista da Universidade da Califórnia foi narrado pela figura "cão", ao guiar os espectadores para dentro do Laboratório de Hidráulica. Ao dizer o presente texto, o cão passeava pelos demais jogadores "instalados" nos modelos físicos reduzidos como se fossem homúnculos. O texto faz referência ao estado de prontidão, de uma maneira criticada pela autora no final do excerto, no entanto o que pretendíamos era um cruzamento de significados: a reflexão sobre o exercício do ator e a apresentação de um espaço cênico repleto de máquinas. A convivência da arte no meio de tantas ferragens era ratificada pelo texto que explicava "cientificamente" a prontidão como uma atividade cerebral. O resultado era ao mesmo tempo metalingüístico, pois referia-se ironicamente a um estado necessário ao ator, pois sabemos que o entendimento prático do estado de prontidão é bem mais complexo que essa explicação neurofisiológica. A emissão do texto era repetida inúmeras vezes até o cão completar o circuito de apresentação de todos os jogadores, em um espaço delimitado.

A repetição como elemento constitutivo talvez seja uma das características mais marcantes da performance. No uso da repetição busca-se um "efeito zen", à medida que a fala continuamente repetida vai criando um som de mantra, hipnótico, que conduz a outros estados de consciência (o chamado estado alfa). Essa repetição 
provoca também uma emissão de mensagem subliminar, que irá ocasionar uma cognição diferente por parte do receptor. (COHEN, 2007, p. 74)

A repetição do texto em loopings minimizava a sua percepção, servindo mais para pontuar a musicalidade da condução do público do que para realmente fazer o público ouvir o texto mais uma vez. Embora a repetição provocasse alterações na percepção e no entendimento do texto, ela permitia que os espectadores se aproximem do assunto. Mesmo de maneira subliminar como afirma Renato Cohen na citação acima, os espectadores tinham seu próprio estado de prontidão solicitado.

Independentemente da quantidade de emissores, os textos ditos são o que Patrice Pavis categorizou como texto impostado (PAVIS, 2005). No caso de um teatro que não parte de um texto formalizado anteriormente, só podemos analisar segundo esse ponto de vista, passagens textuais compiladas no roteiro. O que ainda é possível é observar os fragmentos, refletir sobre o contexto no qual estavam inseridos e, depois de deslocados, analisar sua relação com o ambiente da encenação.

O outro monólogo foi retirado do roteiro do filme São Paulo S/A, de Luiz Sérgio Person:

Recomeçar, trabalhar, mil vezes tentar ser um homem, trabalhar pra tudo, esquecer Ana, apagar Luciana, não lembrar senão do trabalho, das (cinqüenta) obrigações diárias. Lembrar somente das (chateações diárias) do trabalho. Lembrar [...] engrenagens. $E$ mais outra. E mais outra. E mais outra. De uma engrenagem. E depois do eixo. Que deve ser entregue dentro do prazo estabelecido. Mil vezes recomeçar. Recomeçar de novo. Recomeçar sempre. Esquecer Ana. Apagar Luciana. Lembrar-se das cinqüenta obrigações diárias do trabalho.

A transposição do texto acima, do filme para a encenação teatral, pode ser considerado um exemplo de situação desvinculada da fala, pois ele era dito enquanto uma figura, no alto de uma viga de metal, masturbava-se. Embora o assunto da fala dissesse respeito às obrigações e cobranças vivenciadas cotidianamente, a ação praticada denotava prazer e não o aborrecimento que ilustraria o enunciado. Essa réplica era precedida por uma pergunta: "E daí?" que a figura dirigia a um casal que acabara de dizer "Quando a gente não pode 
mais, a gente avacalha, avacalha e esculhamba, porque sozinho a gente não vale nada!", frase extraída do filme "O Bandido da Luz Vermelha", de Rogério Sganzerla. Nesse momento, de cruzamento de vozes, há um diálogo de monólogos, pois o referido casal não dialogava propriamente; ambos compartilhavam o mesmo texto configurando-se como uma figura coral (conjunto de pessoas dispostas paralelamente, sem intercâmbio de informações, um não modifica o outro).

Essa estrutura de enunciação foi bastante utilizada na encenação e se inscreve na noção de coralidade, inicialmente proposta por Jean-Pierre Sarrazac no livro "L’Avenir du drame" e posteriormente, discutida por vários teóricos em uma importante edição da revista belga "Alternatives Théâtrales". Martin Mégevand também discutiu a noção de coralidade no artigo citado abaixo, no qual afirma que ela pode servir para qualificar estéticas híbridas, próximas da instalação, apoiadas apenas sumariamente no texto. $O$ autor ainda afirma que a coralidade nasce em um tempo que o coro já não pode mais existir, devido ao fim das utopias e das ideologias, acompanhado pela dissolução das comunidades. Sabemos que o coro preconizado pelos gregos representava a voz do povo, a opinião pública, e caracterizava-se por comentar a ação. A coralidade aparece em um contexto de falas estilhaçadas, como um conjunto refratário de vozes, um coletivo discordante. Nesse sentido, Mégevand considera a coralidade inversa ao coro, portador de um ideal uníssono.

[...] entende-se por coralidade essa disposição particular de vozes que não tem a ver nem com o diálogo, nem com o monólogo; que, solicitando uma pluralidade (um mínimo de duas vozes), contorna os princípios do dialogismo, especialmente reciprocidade e fluidez dos encadeamentos, em proveito de uma retórica da dispersão (atomização, parataxe, dispersão) ou do entrelaçamento entre diferentes falas que se respondem musicalmente (fração, sobreposição, ecos, todos efeitos de polifonia). (MÉGEVAND, 2005, p. $37-38)^{32}$

\footnotetext{
${ }^{32}$ Do francês: "[...] on entend par choralité cette disposition particulière des voix qui ne relève ni du dialogue, ni du dialogue, ni du monologue ; qui, requérant une pluralité (un minimum de deux voix), contourne les prinicpes du dialogisme, notamment réciprovité et fluidité des enchaînements, au profit d'une rhétorique de la dispersion (atomisation, parataxe, éclatement) ou du tressage entre différentes paroles qui se répondent musicalement (étoilement, superposition, échos, tous effets de polyphonie)." 
Diante dessas novas formas de estabelecer a função coral na contemporaneidade, as figuras-corais apresentadas na Hidráulica compartilhavam a possibilidade de associação entre o gênero lírico e épico. No primeiro exemplo, citado abaixo, a dupla emitia sua fala diretamente para o público. A estrutura dessa fala, contudo, era fragmentada, ecoada, repetida como um disco riscado, efeito que servia para ressaltar o conteúdo ao qual se referiam (chamávamos esse texto de prólogo, pois de certa forma explicava as ferramentas utilizadas na composição de ISAURA S/A) e para explorar a musicalidade do texto. A fala foi elaborada por uma das jogadoras (Katia Lazarini) a partir da mixagem de textos retirados de duas fontes: a narração dos radialistas do filme "O Bandido da Luz Vermelha", de Rogério Sganzerla e excertos de "O Mundo de Calicó - A Cidade-Cinema da UFA", de Siegfried Kracauer.

Aqui, nesse amplo laboratório hidráulico apresentaremos os elementos retirados do mundo. As cenas são muitas... Parecem as pedrinhas de um mosaico. Uma multidão de grãos de imagens, oriunda de múltiplos lugares permanecem desunidas. $O$ procedimento é rápido, em vez de deixar o mundo nesse estado quebradiço, as coisas são reintegradas ao Terceiro Mundo. As coisas são retiradas de seu contexto e são reintroduzidas, não são para serem levadas a sério. Cada acontecimento foi preparado isoladamente e instalado em seu lugar. Os personagens, assim como os acontecimentos, não pertencem ao mundo, mas ao Terceiro Mundo. É um lixo sem limites senhoras e senhores. Trata-se de um faroeste do Terceiro Mundo. Qualquer semelhança com fatos reais ou irreais, pessoas vivas, mortas ou imaginárias é mera coincidência.

Outro exemplo de figura coral foi composto por dois atores que representavam o político corrupto do filme "O Bandido da Luz Vermelha". O político era uma das únicas figuras da encenação que tinha nome: J. B. da Silva. Sua função coral revela-se até mesmo no caráter de ser alguém nominável, pois uma figura pública tem um nome, ainda que represente toda corja de políticos corruptos. Em todas as aparições ele era um duplo, explicitando seu comportamento dúbio. Na primeira aparição, na qual profere o texto citado a seguir (dito por Arturo, personagem do filme São Paulo S/A, de 
Luiz Sérgio Person), o público via a imagem do ator Júlio, que dublava a voz do ator Felipe.

\begin{abstract}
E afinal das contas, o que é o café?... Tá certo, o que ele ainda pesa na balança. Sem ele, o Brasil já estaria perdido. Mas o café é o presente, o futuro está aqui, Carlos. É a indústria que vai decidir. É o aço, o petróleo, nossas máquinas, nossos automóveis, nossos tratores. E quem é que diz a última palavra no assunto? Quem é que comanda? Quem é que puxa tudo isso pra frente? Me diga? É São Paulo, meu velho! É São Paulo! Essa terra de gente que trabalha. Somos nós que impulsionamos o Brasil, somos nós o motor. São Paulo cresce e não parará de crescer. Você se lembra alguns anos atrás, quem pensava que o Brasil ia fabricar automóveis? Quem acreditava que de um dia para outro surgiria tudo isso que você vê na sua frente...? Duas mil indústrias de autopeças como a nossa, mais de duzentos mil veículos por ano, assim, de uma hora para outra, já pensou?
\end{abstract}

Na segunda aparição, essa ambigüidade era revelada pela bipartição do "personagem" na figura do político (Júlio) e de um jornalista que o entrevistava (Felipe). Os jogadores insinuavam que a imprensa também estava sob o controle da corrupção política, ao propor que o jornalista fosse integrado na figura do político, pois os mesmos atores jogavam a função do jornalista. $\mathrm{Na}$ última aparição dessa figura coral, os dois atores estavam posicionados em uma escada, espelhados - um com a cabeça para cima e o outro com a cabeça para baixo - como se tivessem saído de uma carta de baralho. Nesse momento, aparece outra jornalista, liberando a dupla política para representar a dubiedade de sua constituição. Mesmo essa jornalista, que aparentemente denunciava o modo de vida de J.B. da Silva, recebe favores sexuais do político por debaixo dos panos (uma das cabeças do político simulava fazer sexo oral na jornalista durante sua fala de repúdio ao seu comportamento).

Outro tipo de coralidade foi explorada através de um dos únicos textos emitidos por todos os jogadores: "As Cidades Delgadas 1", uma das Cidades Invisíveis de Ítalo Calvino. Todos os integrantes da encenação estavam espalhados pelo galpão, completamente iluminado, revelado na íntegra (cena já citada, intitulada "Panorâmica). Eles jogavam o texto uns para os outros, reproduzindo o jogo da flecha de atenção (descrito na próxima lista da Coleção 
de Jogos do Olhar). O texto abaixo (com alguns cortes a partir do original) foi trazido pela jogadora Adriane Escher em um protocolo e configura-se um exemplo de infiltração de narrativas literárias no contexto teatral. A descrição da cidade invisível "Isaura", de onde tiramos o nome da encenação, serviria perfeitamente para descrever nossa locação, o Centro de Ensaio de Máquinas da Hidráulica. (CALVINO, 2000, p.24)

Presume-se que Isaura, cidade dos mil poços, esteja situada em cima de um profundo lago subterrâneo. A cidade se estendeu exclusivamente até os lugares em que os habitantes conseguiram extrair água escavando na terra longos buracos verticais: o seu perímetro verdejante reproduz 0 das margens escuras do lago submerso, uma paisagem invisível condiciona a paisagem visível [...]. [...] Isaura [...], segundo alguns, vive nas profundidades, no lago negro que nutre as veias subterrâneas. Segundo outros, [...] [Isaura] vive $(m)$ nos baldes que, erguidos pelas cordas, surge nos parapeitos dos poços, nas roldanas que giram [...], nas alavancas das bombas, nas pás dos moinhos de vento que puxam a água das escavações, nas torres de andaimes que sustentam a perfuração das sondas, nos reservatórios suspensos [...] no alto dos edifícios, nos estreitos arcos dos aquedutos, em todas as colunas de água, tubos verticais, tranquetas, registros, até alcançar os cataventos acima dos andaimes de Isaura, cidade que se move para o alto.

Fiz algumas adaptações no texto com o intuito de facilitar sua apreensão. Mesmo sendo um texto basicamente descritivo, apresenta dificuldades na memorização, por sua forma repetitiva. Entretanto, justamente essa forma repetitiva explicita a materialidade do texto através da musicalidade presente nele, uma aliteração. Por exemplo, a repetição da letra "p" em "parapeitos dos poços" e da letra "t" em "tubos verticais, tranquetas, registros, até alcançar os cataventos". O autor também brinca com palavras de sentidos próximos, confundindo o ator e o espectador e, ao mesmo tempo, enfatizando determinadas características. São exemplos da profundidade do espaço, as palavras: poços, buracos, escavações, perfuração. Refere-se à água ao dizer: reservatórios, poços, água, lago, verdejantes, margem; reafirma a verticalidade do lugar em: colunas, tubos verticais, veias; demonstra o movimento do ar com: roldanas, giram, pás, moinho, vento, catavento, move e ainda insiste na altura 
de Isaura da seguinte forma: torres, andaimes, sustentam, suspensos, alto, edifício, aquedutos, andaimes, alto.

Parece-me que o autor não está preocupado com a apreensão do texto na íntegra; ao contrário, ele cria um manancial de imagens sobrepostas. 0 texto nos dá a idéia de um lugar vertical, profundo e alto, pois todas as imagens que se referem à horizontalidade são finitas: perímetro, margem e paisagem. Ítalo Calvino descreve um lugar, uma cidade, de dimensões visíveis, porém repleta de perfurações e buracos subterrâneos os quais não podemos dimensionar. Além disso, o trabalho em Isaura gira em torno da manipulação da água. As informações iniciais sobre Isaura são: provavelmente ela esteja situada em cima de um profundo lago subterrâneo e tenha se estendido até os lugares em que os habitantes conseguiram extrair água. As informações posteriores referem-se aos modos com os quais os habitantes lidam com a água. Diante dessas informações, Calvino poderia estar descrevendo a Hidráulica: galpão vertical, com dimensões visíveis e subterrâneos invisíveis, úmido, repleto de máquinas para a realização de experimentos com a água, de cor predominantemente verdejante.

(protocolo de Adriane Escher)

"O encontro de hoje criou uma relação mais humana com a encenação. O nome Isaura foi gritado, procurado, choramingado... Era como se houvesse uma pessoa hidráulica perdida, aprisionada e revelada. As cenas se relacionavam algumas vezes menos maquinalmente, como uns seres primitivos, misto de gente-bicho-máquina, e muitos pássaros. Um diálogo sem logicidade nas palavras soltas, ruídos, sons, gritos."

O texto de Ítalo Calvino foi memorizado pelo grupo em jogo (descrito na Coleção de Jogos do Olhar). Parte das questões investigadas pelo grupo referia-se à concatenação dos movimentos com os textos. Propostas de experimentação de movimentação repetitiva ajudavam a perceber como saía o impulso vocal, mas em longo prazo acabam gerando uma exploração mecanizada do texto. Por isso, alternamos a proposta anterior com movimentações mais livres de partes restritas do corpo (cabeça, cintura escapular ou quadril) associadas ao texto.

Essa cena merece um cuidado especial, ainda que em muitos momentos sua execução revelasse algumas imprecisões no corpo e na apreensão do texto. A posição da "panorâmica" no roteiro da encenação foi determinante de 166 
toda a ordenação das cenas, pois nela o espaço seria exposto na sua grandeza, com sua iluminação original. Tudo que a encenação buscou escamotear do espaço, revelando-o aos poucos e criando uma sensação labiríntica nos espectadores, era escancarado nesse momento. Além disso, a posição estratégica dessa cena dentro do roteiro encerra o momento de apresentação dos fatos. A partir da "panorâmica" nada mais é acrescentado, todo o movimento da encenação se encaminha para fechamentos das linhas narrativas. Retomaremos dessa discussão no último item do capítulo, ao analisar a macro-estrutura da encenação.

Ainda em relação à quantidade de emissores dos textos presentes no roteiro de ISAURA S/A, podemos destacar a presença do diálogo, apenas um em toda a encenação. Retirado do roteiro do filme São Paulo S/A, de Luiz Sérgio Person, trata-se de um diálogo cujas didascálias foram levadas à cena, mesmo sem terem sido escritas com esse objetivo. Optamos por colocar uma narradora dizendo as didascálias e cedendo a palavra aos personagens, atividade que poderia ser considerada como função do sujeito rapsódico. Colocar as descrições presentes nas didascálias em cena nos interessava na medida em que o espaço onde a cena estava ambientada não correspondia definitivamente à descrição. O confronto entre o emitido e o contexto da emissão promovia a demanda da atenção do espectador, uma vez que a fala não ilustrava a situação. Por outro lado, as réplicas de Carlos vez ou outra escapavam para o poético, descrevendo a paisagem. Esse emprego ou infiltração do lírico na fala do personagem contribui para a "desdramatização" da situação.

Dunas. Ruído de lancha. Cobrindo a praia e entrando pelo lago, um pontilhão, onde Carlos e Ana passeiam. Conversam.

Carlos - Existe sempre um porto. É um porto ainda quando não é.

Ana - Carlos, o que é esse lugar?

Carlos - Era... Hoje não é mais.

Ana - Carlos, o que era este lugar?

Carlos - Era um porto, um porto de areia.

Ana - Areia, barcos. Os barcos, o que eram?

Carlos - Os barcos não eram barcos. Os barcos eram batelões. Os batelões eram para a areia. A areia era para o vidro. Hoje a areia não é mais para o vidro. Hoje não tem mais vidro. Hoje não tem mais.

Latidos apavoram Ana. 
Ana - Carlos!

O cão persegue Ana que abraça Carlos.

Na imensidão do lago, uma canoa, Carlos rema, Ana diante dele. Passa uma lancha.

Ana - Olha, Carlos, quero uma lancha grande como aquela ali!

Em relação à cena acima, optamos por manter os nomes das personagens do filme nas figuras da encenação. No entanto, parodiando o personagem seriamente estruturado do filme, vinculado a três amantes diferentes, deixamos a amada de Carlos receber vários nomes ou qualquer um deles, ao invés de um nome só. Não considerávamos relevante que aquela figura tivesse status de personagem, ela não tem identidade a ser afirmada. Todos seus nomes terminavam com Ana: Luciana, Juliana, Fabiana. A identidade presente no nome é de caráter geográfico, já que essa combinação de nomes só é possível no Brasil.

Tal fator pode ser percebido no roteiro em anexo. Poucas figuras têm nome, na maior parte das vezes as réplicas são atribuídas aos atores pela inscrição de seus nomes antes delas. Optar por falar de figura e não personagem revela o enfraquecimento do personagem, a tal ponto que o que se esboça em cenas são figuras que detêm uma unidade simplesmente por serem apresentadas no corpo de certo ator. Não há encarnação de personagem, o que se nota são personas ou figuras, facetas de um ator que executa ações físicas. Por isso, pedia aos jogadores que se lançassem no espaço como pessoas, não como personagens. Muitas vezes o que se percebia em ISAURA S/A, eram silhuetas mais ou menos anônimas, plantadas no espaço.

Quanto à presença ou ausência do emissor no espaço cênico, tomamos emprestado uma noção da linguagem cinematográfica: fala-se em voz in, voz off e voz over. A primeira delas é a voz do texto que é dito por alguém em cena, a ocorrência mais tradicional. A segunda, voz off, é proferida por alguém que está fora do quadro, ou seja, o emissor está presente na diegese, mas não está sendo visto no momento em que fala. Essa noção é comum também no teatro, quando se fala da coxia, por exemplo, diz-se tratar de uma voz off. A última ocorrência, voz over refere-se a um emissor que não faz parte da diegese, está ausente do espaço-tempo da cena. Segundo o professor Ismail 168 
Xavier, a voz over "é esta que se superpõe às imagens e cujo foco emissor é indeterminado ou se encontra em outro espaço frente ao observado pela câmara" (XAVIER, 1997, p. 128). Nesse ponto, chegamos ao texto ouvido, referido no título desse item da dissertação. Na nossa tradução de procedimentos cinematográficos, utilizamos esse tipo de voz gravando textos e sobrepondo-os à cena. Dessa forma, produzimos vozes ausentes, emitidas por figuras alheias ao contexto da cena que se apresentava. Podemos citar no mínimo dois exemplos de coralidades auditivas: uma constituída por todos os membros do coletivo, em uníssono; e outra, por uma figura coral, também ausente da cena apresentada, pois apenas ouvimos sua voz em áudio, não vemos sua imagem.

No primeiro caso, tratava-se do "Manifesto Futurista", de Marinetti, retirado do texto "A obra de arte na era da reprodutibilidade técnica", de Walter Benjamin e trazido para o grupo em um encontro de estudos teóricos. $\mathrm{O}$ áudio desse texto era sobreposto a uma cena produzida a partir de um retroprojetor. O aparelho serviu como recurso para a produção da cena, pois um dos políticos manipulava uma tampinha de embalagem plástica presa a uma agulha de costurar bonecas (por isso, bastante comprida) sobre a tela do retroprojetor. Ao ser projetado na parede, a sombra desse pequeno objeto era transformada numa cápsula que prendia os jogadores que se encontravam em uma passarela muito alta e distante do público. A imagem mostrava a manipulação de seres humanos, realizada por um político sorridente e despreocupado, enquanto o áudio reproduzia um discurso de louvor às belezas da guerra - 0 Manifesto Futurista.

Manifesto de Marinetti sobre a guerra colonial da Etiópia.

Há vinte e sete anos, nós futuristas contestamos a afirmação de que a guerra é antiestética... Por isso, dizemos:... a guerra é bela, porque graças às máscaras de gás, aos megafones assustadores, aos lançachamas e aos tanques, funda a supremacia do homem sobre a máquina subjugada. A guerra é bela, porque inaugura a metalização onírica do corpo humano. A guerra é bela, porque enriquece um prado florido com as orquídeas de fogo das metralhadoras. A guerra é bela, porque conjuga numa sinfonia os tiros de fuzil, os canhoneiros, 
as pausas entre duas batalhas, os perfumes e os odores de decomposição. A guerra é bela, porque cria novas arquiteturas, como a dos grandes tanques, dos esquadrões aéreos em formação geométrica, das espirais de fumaça pairando sobre aldeias incendiadas, e muitas outras... Poetas e artistas do futurismo... lembrai-vos desses princípios de uma estética da guerra, para que eles iluminem vossa luta por uma nova poesia e uma nova escultura! (BENJAMIN, 1994, p. 195-196)

No segundo caso, uma figura coral apresentava o texto de Alan Lightman, retirado do livro de Helena Katz e tal gravação era sobreposta a uma cena em que um casal experimentava diversas posições para 0 ato sexual. 0 cientificismo do texto eliminava qualquer sentimentalismo que poderia ser projetado na imagem do casal. A negação da impressão de realidade da cena era reforçada pelo fato do casal explorar seu "kamasutra" sobre um dos tubos verdes da Hidráulica. Assim, o interesse que a cena de sexo causava no público era incomodado pelo risco que aparentemente os atores corriam. Embora seguros e preparados para a realização da cena, a impressão da platéia era de que os jogadores podiam cair em um dos poços de água do Laboratório.

[...] o corpo não é o resultado de uma mágica fantástica mas uma coleção de elementos químicos, tecidos e impulsos nervosos. Pensamentos não são mais que oscilações elétricas no cérebro. Excitação sexual não passa de um fluxo de elementos químicos para as extremidades de certos nervos. Tristeza nada mais é que um pouco de ácido transfixado no cerebelo. Em resumo, o corpo é uma máquina, sujeito às mesmas leis da eletricidade e da mecânica que um elétron ou um relógio. Portanto, ao falar do corpo deve-se usar a linguagem da física. E, se o corpo fala, é a fala de nada mais que um número de alavancas e forças. O corpo não é uma coisa a que se obedece e sim uma coisa em que se manda. (KATZ, 2005, p. 60)

Ainda podemos observar a presença da conversa descompromissada, sem projetos e pouco elaborada, sendo improvisada por um jogador que telefonava para o celular de duas pessoas da platéia. Antes de iniciar cada sessão, os espectadores assinavam um termo de compromisso, no qual anotavam seus celulares, caso estivessem com eles no momento. Uma pessoa da equipe técnica encarregava-se de passar alguns números de telefone para o celular que era usado na cena. Como os espectadores eram incentivados a 
manterem seus celulares ligados e não se desconectarem do mundo, um celular tocava e o ator em cena comunicava-se com a pessoa do público escolhida. Nessa cena, o ator não olhava diretamente para o espectador, apesar de todos perceberem com quem o ator falava. Algumas vezes o jogador utilizava o recurso do "viva voz" do celular, para que todos os espectadores ouvissem a conversa. Quando a pessoa que recebia a chamada não atendia ao telefone, o ator deixava um recado para ela, dizendo compreender sua escolha por não atender ao telefone enquanto assiste a uma peça de teatro. A qualidade dessa fala destoava das demais, revelando as alterações no estatuto do texto na atualidade.

Há ainda um lugar para o texto nesse teatro centrado na imagem: o texto grafado ou projetado em cena, ressaltando sua materialidade. O texto, apresentado como texto propriamente dito, remete à sua função primeira: ser lido, observado na sua grafia e não ser ouvido. Em ISAURA S/A, esse recurso foi utilizado duas vezes. A primeira, em uma pichação realizada sobre suporte de jornais velhos, como referência ao filme "Bandido da Luz Vermelha": "Woce pulicial do mal seu boçal woce naum me pegará nunca. Ass." Todas as vezes que o bandido do filme escrevia, sua escrita revelava seu contexto cultural: origem pobre, provavelmente mal alfabetizado e afeito aos estrangeirismos, por isso a substituição da letra "v" pelo "w". A opção por escrever "naum" ao invés de "não" foi feita pelo jogador que atualizou a escrita do bandido para o tipo de escrita praticada nas conversas pela internet.

Outra ocorrência de texto grafado acontecia, quando a figura do cão retomava a condução do público, para o fechamento da encenação. Diante do modelo físico reduzido que chamamos de "aquário", o cão observava as ações da jogadora Larissa e, em seguida, escrevia no vidro "foi assim que ensaiei pra morrer", frase do filme "O Bandido da Luz Vermelha". Na seqüência, o público era conduzido de volta ao portão inicial e, ao passar pela "piscina de musgo", deparava-se com a imagem da figura que ocupava esse espaço no início da encenação, dependurada, com uma capa de chuva transparente, na qual podiam ler a inscrição: "foi assim...". A presença do texto grafado, para ser lido, evidencia o tratamento dado ao texto, como materialidade visual e sonora, no que tange à musicalidade do texto. Ao ser transformado em imagem, o texto é liberado de interpretações psicologizantes e seu estatuto é revelado como 
presença visível e não só audível. O texto visto em cena é uma citação da experiência literária. Embora não entre em contato com o texto por meio do suporte papel, o ato da leitura, da decodificação dos signos lingüísticos convida o espectador a complementar a cena com imagens formuladas a partir de sua enciclopédia pessoal, como diz Umberto Eco.

No teatro contemporâneo fala-se cada vez menos em personagens e mais em organização das vozes narrativas. Jean-Pierre Sarrazac aborda essa questão analisando o partilhamento das vozes nos textos dramáticos e nas encenações. No caso de um roteiro composto coletivamente a partir de fragmentos provenientes de múltiplos lugares, há uma profusão de vozes. $\mathrm{Na}$ encenação na Hidráulica, podemos identificar um entrelaçamento das vozes dos autores originais dos textos empregados na cena. De certa forma, esse modo de escrita de roteiro por apropriação de textos alheios se assemelha a um gênero cinematográfico conhecido por found footage, prática de fazer filmes a partir da compilação de materiais de arquivo. A voz da encenação é resultante do processo de montagem. É a voz do montador que se eleva acima de todas as outras, pois ela rearticula as vozes narrativas em função do discurso da encenação. No nosso caso, pode-se dizer que a função do montador foi, na maior parte das vezes, compartilhada entre integrantes do Coletivo, salvo algumas ocasiões em que a direção realizou escolhas pontuais. O Núcleo de Dramaturgia encarregado de "ler" as cenas, ou de acordo com a tradição grega, colher seus significados, também operou a voz do montador.

\section{Coleção dos Jogos do Olhar - Texto}

Apresentaremos a seguir uma parte da Coleção de Jogos do Olhar dedicada ao estudo do elemento Texto. A ênfase dada a esse elemento da escrita cênica não desconsidera os demais elementos presentes na cena. Corpo e o Tempo estão engajados nas modalidades de jogo descritas abaixo.

\footnotetext{
Jogo para memorização do texto em conjunto:

Modalidade de jogo apreendida com Lu Carion, que por sua vez partiu das proposições de Rainer Vianna (filho de Klauss Vianna). Trata-se de uma forma de apropriação de um texto em jogo, importante para que os jogadores não
} 
mecanizem o texto ao decorá-lo. Esse jogo para memorização do texto é um desdobramento de um jogo de apresentação dos jogadores, comum no início dos processos. Descrevemos o jogo em itens que vão sendo sobrepostos na medida em que o jogo progride:

1. Todos os jogadores estão em círculo. Uma pessoa caminha em direção a outra olhando em seus olhos, com precisão, assumindo seu lugar no círculo. Essa, por sua vez, escolhe outra pessoa do círculo e faz o mesmo.

2. Durante a caminhada, os jogadores dizem o próprio nome, apresentando-se a outra pessoa. É importante manter a precisão na simples ação de andar, articular bem o próprio nome e manter um volume audível, além de sustentar o foco no olhar.

3. Seguindo a mesma estrutura, o jogador diz o nome da pessoa para a qual caminha, testando sua capacidade de memorização dos nomes em um jogo de atenção e escuta.

4. Durante o estudo das dobras do corpo, essa estrutura de jogo pode ser usada incluindo movimentos parciais (com apenas uma articulação ou grupo articular) durante o percurso entre a posição inicial do círculo e a pessoa escolhida. Durante a caminhada pode-se experimentar dizer o nome da articulação movida, associando o movimento ao modo de dizer o nome.

5. Para memorizar um texto, os jogadores podem explorar a mobilidade das articulações, enquanto repetem algumas vezes as frases ditadas pelo professor. A repetição da frase em jogo faz com que os jogadores explorem muitas maneiras de dizer a frase, não se restringindo à sua entonação inicial, pois a alteração dos movimentos leva à alteração do modo de dizer o texto.

\section{Jogo da flecha de atenção:}

Todos os jogadores estão dispostos em círculo. Um deles lança uma palma na direção de outro, de forma precisa, com a ajuda do olhar que também foca a pessoa mirada. Aquele que recebe a palma/flecha a devolve para qualquer outro jogador da roda e assim continua sucessivamente.

Após um período de jogo em silêncio, acrescenta-se o texto já decorado, promovendo quebras na estrutura da pontuação. Ou seja, o jogador não precisa passar junto com a palma uma frase na íntegra, ele pode interromper o 
fluxo da frase quando quiser. Desse modo, caberá ao próximo jogador completar a frase iniciada pelo jogador anterior. Nesse caso, todos os jogadores têm que conhecer o mesmo texto.

\section{Jogo para a apropriação do texto:}

Este jogo foi desenvolvido a partir de jogo proposto em sala de aula pela professora Maria Lúcia Pupo (ver PUPO, 2005).

Todos caminham pela sala lendo o texto impresso, simultaneamente, cada um no seu tempo.

Em seguida, experimentam a leitura em uníssono.

Depois, um jogador começa a leitura e interrompe quando quiser, sem necessariamente seguir as pontuações do texto. Imediatamente, outro jogador retoma a leitura do ponto em que o jogador anterior interrompeu. Caso dois ou mais jogadores leiam juntos, podem continuar a leitura.

Propõem-se certas alterações no ambiente para que o grupo realize algumas ações, tais como: o chão está cheio de sabão, só é possível caminhar sobre cordas bambas, o chão está pegando fogo, o ar da sala dá choque. $\mathrm{Na}$ medida do possível, os jogadores continuam lendo o texto, escolhendo frases e repetindo-as enquanto exploram tais movimentações. Essa proposta faz com que os jogadores alterem as formas de dizer o texto, descondicionando a primeira leitura e abrindo uma infinidade de possibilidades.

Propõem-se ainda alterações no modo de falar o texto, como por exemplo: dizê-lo para alguém que está muito longe, cochichar para alguém ou dizê-lo como discurso, tal qual um político.

\section{Trilha Sonora: vozes, ruídos, música gravada e desconstruída}

Ao falar em trilha sonora consideramos toda a paisagem sonora percebida em uma encenação: vozes, músicas e ruídos produzidos pelos jogadores ou gravados. Além disso, os sons produzidos no espaço, resultado do encontro dos corpos com o espaço, e os sons presentes no espaço também são considerados. A arquitetura que recebe o teatro, mesmo que seja um palco tradicional, possui uma sonoridade, própria do ambiente, tal qual uma locação. Além disso, todas as modalidades de aparecimento do texto nesse teatro das 
imagens dizem respeito à trilha sonora: tanto os textos ditos e ouvidos (tratados no item anterior) quanto os fragmentos textuais, mais próximos da musicalidade dos sons do que da integridade da palavra (esses serão tratados mais adiante).

Durante a análise do roteiro final de textos e cenas ao qual chegamos no Experimento Hidráulico, notamos que boa parte das significações eram acionadas por meio da introdução de ruídos decorrentes da produção de ações no espaço. Diferente do que acontece na criação cinematográfica, na qual a captação do som durante as filmagens é complementada pela inserção de sons na hora da montagem, na composição teatral é possível descobrir sons durante o processo criativo e propor a inserção deles no ato da apresentação. Também seria possível, embora não haja no teatro a edição do material teatral como há com o material fílmico, a gravação de sons captados em lugares distintos da locação e, posteriormente, a inserção desses sons na encenação. Entretanto, não chegamos nesse nível de experimentação, como no exemplo citado abaixo:

Não há nos espetáculos do Cosmos Kolej cenário naturalista visando criar um efeito de real. [...] Não é o que se vê que cria a ilusão, é o que se ouve. $\mathrm{O}$ universo sonoro é feito de ruídos naturais captados que são em seguida retrabalhados ( $85 \%$ da música e dos sons de Ulysse vêm da Irlanda) e montados com a partitura. (AUTANTMATHIEU, 2004, p. 337, tradução da autora) $)^{33}$

O exemplo acima se refere à encenação Ulysse à l'envers, do encenador polonês Wladyslaw Snorko, do grupo Cosmos Kolej. Seguindo o modelo de Tarkosvki, cineasta russo, o encenador polonês retira sons do mundo real e os distorce, os esculpe e os aplica como partitura sonora em suas peças. De acordo com Tarkovski, quando o som não tem mais relação com a imagem, o filme encontra uma ressonância própria. Snorko, por sua vez, não trabalha com um dramaturgo, mas com um inventor de sons que molda a matéria sonora, misturando sons verdadeiros (reais) e sons falsos (manipulados).

Os registros em áudio organizados para ISAURA S/A compreendiam os textos, apresentados nos diversos jogos com as vozes: ao vivo ou registradas, ${ }^{33}$ Do francês: "Il n'ya pas dans les spectacles du Cosmos Kolej de décor naturaliste, visant à
créer un effect de réel. [...] Ce n'est pas ce que l'on voit qui crée l'illusion, c'est que l'on entend.
L'univers sonore est fait des bruits naturels captés qui sont ensuite retravaillés ( $85 \%$ de la
musique et des sons d' Ulysse viennent d'Irlande) et montés avec la partition. " 
faladas ou cantadas, contextualizadas ou descontextualizadas. Além disso, havia também um caso especial de emissão sonora: um texto retirado do filme Bandido da Luz Vermelha que era "microfonado". Tratava-se, portanto, de uma voz amplificada. Segundo Renato Cohen, na arte da performance "dificilmente um texto é dito sem o uso de aparelhagem eletrônica" (COHEN, 2007, p. 74). No nosso caso, esse foi o único momento em que usamos a fala apoiada em microfone, o que remetia explicitamente ao contexto midiático (televisão, rádio, filme) de onde o discurso foi extraído. Na citação abaixo, o autor discorre sobre a presença das vozes "eletronificadas", pelo microfone e pela gravação (caso da voz over referida anteriormente).

A principal razão para a "eletronificação", a nosso ver, é que a arte é reflexo do tempo, do modus vivendi de uma sociedade; estamos em plena era da eletrônica, da cibernética. O som que fica no subconsciente é o som da mídia - o som da televisão, do rádio, da música eletrônica, do computador. (Ibidem, p. 74-75)

Na cena, a jogadora tinha sua voz "microfonada" enquanto narrava a estória do Bandido da Luz Vermelha, cuja trajetória foi veiculada pela televisão, constituindo-se um dos bandidos mais famosos da década de 1970, antes mesmo do filme de Rogério Sganzerla. Nessa cena, a voz "microfonada" era in, pois os espectadores assistiam à figura que falava no microfone. A seqüência na qual essa voz é inserida é um caso de sobreposição de diversas informações sonoras. Além da voz que diz o texto amplificado, havia uma batida insistente, produzida por um jogador sobre uma barra de ferro, pontuando o discurso de apresentação do bandido e a incidência de duas palavras soltas: sim e não. Essas palavras são o fragmento do fragmento e eram repetidas por uma figura de olhos vendados, como resposta às batidas estridentes do ferro.

A criação dessa imagem surgiu em decorrência da exploração da cabine onde a figura estava inserida. Um antigo programa de televisão em que o apresentador Sílvio Santos vendava uma criança, a colocava dentro de uma cabine, com um fone no ouvido e perguntava se ela queria esse ou aquele brinquedo, foi a motivação dos jogadores para a composição dessa cena. Chegamos a essa situação a partir das leituras das fotografias criadas no espaço, uma etapa do trabalho em que os jogadores revelam seu repertório, 
sua "enciclopédia pessoal". Por exemplo: nas explorações de recortes fotográficos na Hidráulica, alguns títulos de imagens foram "batalha naval" (jogo de tabuleiro), "animação de computador", "dentro do meu inconsciente", "playmobil" (um brinquedo), "plataforma de petróleo da Petrobrás", "sala de tortura", "show de Truman" (um filme), "submarino", "supermercado do Atari" (jogo de videogame). Observados de forma descontextualizada podem parecer estranhas tantas informações aleatórias, contudo os títulos acima resumem o universo de referências dos participantes ativado pelo jogo no espaço da Hidráulica. Esse é um momento de revelação do contexto cultural do grupo, no qual todas as alusões são bem vindas, sem julgamentos de valor.

O que vale, em um processo pedagógico, é o modo pelo qual o universo referido é ressignificado e o quanto o processo criativo oferecerá recursos para que esse universo seja ampliado e revisto. Portanto, a citação ao programa de televisão acaba não sendo evidente na encenação, mas constituiu-se como ponto de partida para o jogo, cuja função acabou recaindo sobre a reorganização simbólica do universo referencial. Ao jogar a cabine do Sílvio Santos de modo quase macabro, os jogadores olharam criticamente para o programa de televisão, questionaram o modo de tratar os desejos das crianças e puderam, talvez, sublimar a experiência vivenciada através do outro, caso sentissem algum pavor ao se imaginarem no lugar daqueles que tinham os olhos vendados.

O discurso caleidoscópico ao qual chegamos na Hidráulica, na maioria das vezes, era emitido na direção do público, mas não se destinava a ele. A palavra ecoava no ar, buscando ressonadores no espaço, não interlocutores. A palavra revela-se não somente no que era dito, mas no que era feito de sua materialidade. Exemplo disso são tais réplicas compostas por frases soltas ou palavras que, repetidas, tinham seu sentido subvertido (como por exemplo, o "sim" e o "não" da cabine). Pela fragmentação da emissão, às vezes funcionavam como turbulências do discurso ou interrupções no fluxo da cena. As frases abaixo, inicialmente, não tinham destinatário preciso.

Quero virar pedrinha de gelo. Me faz pedrinha de gelo?

Esse final de semana vou me dedicar aos boçais. Nasci para os boçais. 
A primeira frase foi pinçada do filme "São Paulo S/A", de Luiz Sérgio Person e a segunda, do filme "A mulher de todos", de Rogério Sganzerla. A primeira vez que essa frase era dita na encenação, a atriz emitia a frase para si mesma, molhando seus cabelos com uma garrafa de água, sem jamais direcionar-se para o público. O ruído da água jogada contava tanto quanto a frase emitida. No segundo momento em que retomamos essa frase, na cena intitulada "Antifesta", uma das jogadoras experimentava lançar a frase a outro jogador, que a rejeitava. Toda a cena, no entanto, era pontuada por barulhos de água das garrafinhas de plástico que o casal manipulava: ele enchia a garrafa dela, ela jogava água em si mesma, ele jogava água nela. O resultado da mudança no endereçamento da frase redimensionou seu significado, criando novas ambigüidades nas relações entre as figuras emergentes da Hidráulica.

A frase abaixo, do "Bandido da Luz Vermelha", representa o mesmo caso de fragmentação, entretanto o discurso era claramente direcionado ao público. Nesse caso, inclusive, um dos políticos tentava impedir que os espectadores ouvissem, dessem importância à frase.

O terceiro mundo vai explodir, quem estiver de sapato não sobra. $A$ solução pro Brasil é o extermínio total. Eu sou poeta, eu vejo.

Outro exemplo emblemático da fragmentação do discurso ocorria na utilização da palavra "pílula". Repetida inúmeras vezes, o jogador oferecia balas ao público enquanto falava "pílula", explorando muitas modulações na voz com o intuito de fazer com que os espectadores aceitassem as falsas pílulas. Considero esse um exemplo de travelling ou condução do público muito bem sucedido, fruto da interação do jogador com o público. O inocente ato de oferecer balinhas para o público aludia à compulsão por remédios percebida contemporaneamente. Desse modo, ao aceitar uma bala de açúcar, o espectador compactuava simbolicamente com o hábito de resolver os problemas de forma imediata, simplesmente administrando-se pílulas.

Durante todo o trabalho corporal, busquei não dissociar corpo de voz, sempre alertando os atores para a utilização de sons como conseqüência da respiração. Por exemplo, o som pode funcionar como um diagnóstico para verificar se o ator está prendendo a respiração durante o movimento, além de 
externalizar a sensação corporal induzida pela movimentação. O acesso à voz via corpo remete ao estudo de Roland Barthes sobre a voz, no qual critica a adjetivação recorrente nas análises de músicas e propõe, ao invés de um adjetivo, um nome: "grão", quando a música alia a melodia à voz. Refere-se, portanto à música cantada e afirma que "o grão é o corpo na voz que canta, na mão que escreve, no membro que executa" (BARTHES, 1990, p. 244). Desse modo, evitamos práticas vocais que deixem o corpo esquecido e procuramos associar explorações da voz durante as atividades corporais.

No nível da experimentação, algumas vezes percebemos que não era viável a inserção de um som em determinado exercício, tais como os jogos de atenção provenientes de Sotigui e de Anne Bogart. Por outro lado, notamos que os jogos de exploração do espaço serviam igualmente para a percepção dos limites da voz, de sua amplitude e possibilidades de projeção, constituindose uma via de mão dupla para o corpo e a voz. Patrice Pavis aponta a semiologia barthesiana como referência para a observação da voz, em detrimento de uma semiologia clássica calcada na comunicação da voz do autor.

Tal semiologia em trabalho se impõe para o estudo do ator, se quisermos captar essa impureza do texto e essa corporeidade da voz nua que é talhada no mesmo pano que o corpo do locutor. Evitaremos, nas descrições, separar as observações sobre a voz daquelas sobre a corporeidade do ator: assim como se pode discernir se a voz ao telefone sorri, devemos poder sentir o corpo que leva e é levado pela voz. (PAVIS, 2005, p. 127)

Aproveitando a formação advinda do OBARA - Grupo de Pesquisa e Criação em Teatro-Dança, procurei desenvolver um treinamento físico-vocal que permitisse um contato íntimo dos jogadores com seus recursos expressivos: o corpo e a voz. Se pudesse, não separaria essas duas instâncias, criando um novo verbete para os dicionários de teatro: "corpovoz", tentativa que não é nova, mas que ainda não está bastante difundida. Para dar continuidade à pesquisa iniciada no OBARA, busquei colaboradores que pudessem complementar o treinamento que se desenvolvia. No que se refere ao estudo da voz, contamos com a colaboração pontual da colega Paula Carrara, que conduziu um trabalho vocal no qual não desarticulava o corpo da 
voz. Estudiosa da voz, ela desenvolveu iniciação científica sobre a expressão vocal, cuja pesquisa aliada ao encontro com a austríaca Sabine Utiz do Via Rosse Teatro, da Itália, possibilitou a proposição de um treinamento vocal para o Coletivo - Jogos do Olhar.

Seguindo o mesmo objetivo, descobrir recursos para que corpo e voz estivessem sempre interligados, Paula propôs a percepção dos ressonadores do corpo a partir do toque. Inicialmente em duplas, depois individualmente, os jogadores foram convidados a perceber a dimensão da caixa craniana, compreendendo todas as reentrâncias e concavidades, por meio de uma massagem que liberava respiração e, conseqüentemente, a voz. Esse processo continuava, passando pelo pescoço, omoplatas, colo, costelas, coluna vertebral e sacro. Cada ponto do corpo ativado pelo toque correspondia registros sonoros distintos, gerando modulações da voz impressionantes, no que tange à altura (de grave a aguda) e ao volume (do sussurro ao grito). Como desdobramento desse trabalho, Paula propôs que os jogadores experimentassem diferentes ressonadores do corpo, em dupla, através da emissão de um texto. Inicialmente, observavam a vibração da fala por meio do contato de costas com costas, depois de cabeça com cabeça e, por último, por meio do contato das mãos. Essa proposta de jogo foi posta em cena pela dupla que fazia a cena chamada de "prólogo", na frente de um dos portões, do lado de fora da Hidráulica.

O processo de descoberta das potencialidades vocais compõe parte da trilha sonora da encenação. Tais potencialidades se referem tanto a questões objetivas quanto subjetivas, mais difíceis de apreender e nomear. Por isso, revela-se mais uma vez extremamente importante a conjunção dos processos criativo e pedagógico, pois a expressividade do jogador será desvelada na medida em que ele se apropriar de seu manancial de expressão, encurtando o caminho entre a intenção, o impulso, e a concretização de um movimento e/ou sonoridade.

A faixa sonora é composta tanto pela impostação dos textos, quanto pela sonorização do corpo, dos movimentos, independente da presença do texto. Nos dois casos o colorido, a tonalidade e as nuances impregnadas na voz concretizam a emissão do som. As características da performance dos jogadores preenchem as lacunas do texto, anulando sua existência tal qual 180 
aparece no papel, para ser lido. As qualidades do corpo que produzem os ruídos e sonoridades mais abstratas também se tornam autorais na emissão do texto. O corpo do emissor se torna, em parte, também autor do texto. Patrice Pavis diz que "o texto representado e pronunciado pelo ator já está servido por uma cena e signos prosódicos, visuais, gestuais dos quais já não se pode mais fazer abstração" em oposição ao texto lido que "não foi ativado por uma voz humana" (PAVIS, 2005, p.187).

Antes de continuar nossa reflexão, considero relevante apresentar mais um colaborador da pesquisa: o professor Fábio Cintra. Sua contribuição foi fundamental para o aprofundamento da pesquisa vocal e para o reconhecimento do potencial de musicalidade presente no espaço e já latente nas cenas. Responsável pelas disciplinas relacionadas ao estudo da música e do ritmo na cena teatral, o professor do Departamento de Artes Cênicas da ECA propôs uma participação colaborativa no processo, depois de assistir ao ensaio aberto realizado pelo Coletivo - Jogos do Olhar no final de 2007. Quando o professor assistiu ao ensaio, percebeu a massa sonora levantada durante a exploração da Hidráulica como um material bruto que merecia um tratamento musical. Sua colaboração foi de extrema importância, tanto na sala de ensaios, quanto no espaço da encenação, propondo o que os jogadores chamaram de "Jogos do Ouvir".

A primeira proposta do professor referia-se ao reconhecimento e à seleção de sons produzidos pela voz no espaço ou pelo contato físico com ele. A partir desse levantamento, ele pôde nos orientar no sentido de transformar ruídos em arranjos sonoros. Todas as suas escolhas visavam à escuta da musicalidade gerada pela instalação das cenas na Hidráulica. Assim sendo, o corpo e o espaço também se constituíam os territórios da musicalização. No espaço da locação, o professor Fábio Cintra propôs que os jogadores buscassem ressonadores, em duas instâncias: ouvindo as vozes das cenas e explorando a voz e os sons produzidos no atrito com o espaço. Escutando as vozes da cena, pôde orientar os jogadores individualmente, apontando ressonadores do espaço e auxiliando na projeção das falas. A relação do corpovoz com o espaço tornou-se um guia para a resolução de diversas cenas, pois uma simples mudança na direção da cabeça do ator alterava o ângulo de projeção da voz e fazia com que ele fosse ouvido. Ele apontou para 
as diferentes sonoridades provenientes de elementos como vidro, ferro e madeira. Dois exemplos esclarecem sua atuação. No caso da cena do "foguete", orientou que a jogadora Paula aproveitasse o balde que segurava como ressonador para sua voz. Dentro do objeto de cena havia um pouco de água, que usava para limpar as vidraças do galpão (ação característica dessa figura) e a água também servia à amplificação de sua voz. Outro exemplo de ressonador encontrado a partir da proposição do professor Fábio, foi um cubículo que ampliava a voz do jogador Felipe ao falar o texto do político, enquanto Júlio mimava e dublava sua fala. Nesse caso o emissor não era visível, mas procurava posicionar sua boca na direção do público; no entanto ao direcioná-la para dentro do cubículo, este servia de concha acústica, ampliando sua voz, que chegava bem mais nítida até o público.

A investigação sonora do espaço levou os jogadores a descobrirem novos ruídos e a escutarem os ruídos já produzidos em cena, de forma intuitiva e não intencional. Durante a exploração espacial, o professor citou alguns exemplos de sons que havia descoberto, batendo pedaços de madeira ou explorando a voz e convidou os jogadores para uma investigação ruidosa pela Hidráulica. Em seguida, cada jogador mostrou os sons mais interessantes que tinha descoberto. Esse trabalho resultou em arranjos precisos dos ruídos produzidos nas cenas simultâneas (momento de entrada do público no galpão). Definimos quais os sons seriam introduzidos primeiro e experimentamos alternar momentos de silêncios, pausas, entremeados às sonoridades, tai como: gemidos, contagem de números da dança indiana, risadas, barulhos de água sendo manipulada com um balde, passos e estrondo produzido por pulos numa placa de metal. Dessa forma, compusemos com a sonoridade presente no ambiente, escolhendo momentos de ação e de silêncio, em um movimento de pseudo-edição do som. Os exemplos citados abaixo pelo autor (Choral e Bataille) se referem a criações do Théâtre du Radeau.

É de um modo muito sutil, porque quase inconsciente, que se opera no espectador a passagem de um espaço onde o som é o som do lugar (um espaço do tipo teatral) a um espaço onde o som é o som da imagem (um espaço do tipo icônico). Tanto em Choral quanto em Bataille, as técnicas servem para produzir um equivalente do que Michel Chion chama "o som individual ampliado" do cinema, servem 
para produzir acessos de imagicidade: o universo auditivo prolonga o espaço da visão cênica. (MERVANT-ROUX, 2004, p. 371, tradução da autora $)^{34}$

O professor Fábio Cintra nos alertou para a dimensão da Hidráulica, especialmente durante o jogo da "panorâmica", no que diz respeito à velocidade do som. Pelas dimensões do espaço, tudo demorava a acontecer e o como o som é propagado em ondas, da mesma forma, também demorava a chegar. Na Hidráulica o tempo era lento. Por isso o professor propunha aos atores: pronunciar o texto o mais articuladamente possível; buscar registros mais agudos da voz; acentuar as consoantes das palavras e caprichar na pronúncia dos finais das frases. Recomendações importantes às quais complementei: apoiar bem o corpo no espaço, pois a relação concreta do corpo com o mesmo serve de apoio também para a projeção da voz.

O trabalho com o professor foi um impulso para o Coletivo, uma mostra das múltiplas possibilidades de concretização de pesquisas envolvendo professores e alunos na Universidade. Sua colaboração nos orientou na construção do som como linguagem, na substituição de gritos por música, na transformação de ruídos em trilha sonora.

A música é assemântica, ou pelo menos não figurativa: não representa o mundo, diferentemente da palavra. Assim, aninhada no espetáculo, ela irradia, sem que saiba muito bem o quê. Influencia nossa percepção global, mas não saberíamos dizer que sentido ela suscita ao certo. Ela cria um atmosfera que nos torna particularmente receptivos à representação. É como uma luz da alma que desperta em nós. (PAVIS, 2005, p. 130)

Em relação à música propriamente dita, quatro foram selecionadas para compor a trilha sonora de ISAURA S/A, sendo que uma foi veiculada como registro em áudio, uma foi cantada e depois veiculada em áudio, e duas foram praticamente desconstruídas. Citaremos algumas cenas como exemplo da utilização da música na encenação. Nas cenas em que há música, ela é determinante da duração e do andamento. As imagens teatrais, como as do

\footnotetext{
${ }^{34}$ Do francês: "C'est d'une façon très subtile, parce que quasiment inconsciente, que s'opère chez le spectateur le passage d'un espace où le son est le son du lieu (un espace de type théâtral) à un espace où le son est le son de l'image (un espace de type iconique). Tant dans Choral que dans Bataille, les techniques servent à produire un équivalent de se que Michel Chion appelle "le son individuel agrandi" du cinéma servent à produire des poussés d'imagicité : l'univers auditif prolonge l'espace de la vision scénique."
} 
cinema, comportam uma dimensão sonora e uma dimensão temporal. Com a presença da música, geralmente, os atores seguem o ritmo proposto por ela.

$\mathrm{Na}$ encenação não havia proposições de movimentação entrando em conflito com o ritmo proposto pela música; o movimento a acompanhava. A música de Astor Piazzolla utilizada na "piscina amarela" define o tempo de duração da cena. Apesar de dotá-la de atmosfera própria, pois a música tornase um referencial determinante quando colocada em qualquer cena, a movimentação dos atores não foi definida por ela. Assim, as imagens resultantes do encontro dessas figuras, em um espaço recortado pela luz, eram observadas de um ponto de vista determinado, simultaneamente à percepção da música. Porém, as ações realizadas pelos atores não se constituem como coreografia da música; a imagem não a ilustra.

$\mathrm{Na}$ formulação dessa cena, iniciou-se nossa reflexão acerca do foco sonoro, pois a definição do posicionamento da fonte sonora em casos de encenações em espaços não convencionais não se refere somente à melhor posição para o público ouvir a informação sonora, mas ela também cria significados. Como o público assistia a essa cena de um corredor envidraçado, pensamos em posicionar o som no corredor, já que o interesse era que o público ouvisse a música. No entanto, quando experimentamos alterar o foco sonoro para a pequena cabine à esquerda do modelo onde a cena se passava, posicionando o aparelho de som, portanto, mais perto da cena do que do público, o resultado foi espantoso. A mudança do foco para mais perto dos atores estimulou a realização de suas movimentações, sendo que a música ajudava na pontuação dos movimentos. Na nova posição, a música pôde ser veiculada em um volume muito mais alto, preenchendo todo o espaço, sem incomodar o público, que estava protegido pelo vidro. Outro fator significativo dessa mudança foi a qualidade das emissões sonoras dos atores da cena, uma vez que ampliaram o volume e a intensidade de suas vozes para não serem encobertos pela música. A integração dos elementos sonoros à composição visual será discutida no item dedicado à iluminação da locação.

Uma única vez, uma música foi cantada, sem ser desconstruída. Foi o caso da chegada do público na plataforma 1 (onde os assentos eram pequenos bancos de madeira) e viam o cão sentado de costas repetindo o texto "Recomeçar, mil vezes recomeçar..." do filme São Paulo S/A. A única música 184 
cantada seriamente era emitida pelo cão, que ao voltar-se de frente para a platéia, soltava os cabelos e com olhar lânguido cantava "Sabor a mi", de Alvaro Carrillo, música presente no filme "O Bandido da Luz Vermelha". Nessa cena, o foco sonoro era próximo do público, o que provocava sensação de presenciar-se um zoom, pois apenas um pequeno foco de luz a revelava no meio da escuridão. Na plataforma 1, o público estava suspenso, literalmente no meio do galpão, no que se refere à dimensão horizontal e vertical também, pois estavam acima do nível do chão. Considero importante precisar essa disposição no espaço para evidenciar a quebra que se efetua no momento seguinte a esse. Um movimento da figura cantante anunciava a entrada da mesma música gravada, proveniente de alto-falantes posicionados na plataforma 2 (de frente para o público), em volume alto, e acompanhada da entrada de uma luz na plataforma 3 (mais alta ainda e também na frente do público), onde um casal dançava. Intervenção sonora e mudança de luz caminhavam lado a lado na quebra instaurada, sendo que a entrada da música gravada ampliava o cenário acústico, devido à mudança do foco sonoro de próximo e sem amplificação (a voz da atriz) para distante, eletrônico e mais intenso (a música registrada).

Retomando a colaboração do professor Fábio Cintra, anteriormente citada, podemos dizer que pelo menos duas experimentações dos jogadores realizadas na exploração do espaço foram utilizados na composição final das cenas: a marcação realizada pelo jogador Clóvis para o "Coro das Meninas", deitadas no chão (visto em plongée) e a pulsação da música "tema" do filme São Paulo S/A, de Cláudio Petraglia, repercutida nos tubos de ventilação ao final da encenação. Nos dois casos as músicas foram desconstruídas.

$\mathrm{Na}$ ocasião dos ensaios abertos, apresentamos uma cena que chamávamos de "Festa". Nela todos os atores cantavam a música "Izaura" (essa com "z", diferente da "Isaura" do Ítalo Calvino), de Herivelto Martins, acompanhados por um pandeiro. Era um refresco para o público, pois oferecíamos água e dispúnhamos cinzeiros para os fumantes, em um intervalo disfarçado. Na avaliação do ensaio aberto concluímos que aquele espaço de "mortos-vivos" não condizia com a presença de um samba, pois uma comunidade de homens consumidos pela máquina definitivamente não ouve samba. Por fim, os jogadores fizeram uma proposta de transformar a festa em 
caos, deixando o público cercado, enquanto recuperavam algumas cenas de forma "esquizofrênica" (segundo os próprios jogadores). Na primeira tentativa de concretizar o caos, espécie de síntese de diversos momentos da encenação, ele não aconteceu. Alguns pontos chamavam mais a atenção que outros, segundo a observação do professor Fábio Cintra, talvez pela reduzida utilização do som naqueles pontos.

Chegamos à conclusão de que para alcançarmos o caos era necessária uma composição muito clara, elaborada pela justaposição e, em alguns momentos, sobreposição de cenas, buscando algum fio condutor que alinhavasse a construção da cena. Pela primeira vez, preparei em casa a orquestração da cena, imaginando a ordem de entrada e sobreposição de cada uma delas. Desse modo, regendo a entrada dos atores, dispondo Felipe (de noiva) como fio condutor, chegou-se ao caos ou antifesta. Esse pode ser considerado um exemplo de elaboração do tempo na configuração final de uma cena. É importante ressaltar que em nenhum outro momento usei do artifício de pensar uma cena, imaginá-la em casa, sem a presença dos atores, para depois propor sua execução a eles. A criação das cenas sempre se deu de forma colaborativa. A cena, então, realizou-se sem a inclusão da música que citava o nome da encenação ${ }^{35}$. Por isso, buscamos outro momento da encenação em que pudéssemos encaixar a música.

Quando o professor Fábio iniciou seu trabalho com o grupo, buscávamos a desconstrução do samba "Izaura", depois da constatação de que esse ritmo, da forma como havíamos colocado no ensaio aberto, não condizia com o "espírito" da encenação. O caminho que propus foi a transformação da música a partir da letra, já que estávamos ensaiando fora da Hidráulica. Desse modo, passamos a falar a letra da música. Com a chegada do professor, ele propôs uma seqüência minimal ${ }^{36}$. A partir das seqüências desenvolvidas pelo grupo de jogadores, alertou-os quanto às variações de volume, duração e altura, fatores muito relevantes na musicalidade. Ferramentas que passaram a influir na

\footnotetext{
${ }^{35}$ Vale a pena lembrar que a sugestão da utilização dessa música veio do porfessor Luiz Fernando Ramos, que assistiu a um ensaio em setembro de 2007, antes mesmo da realização dos ensaios abertos.

${ }^{36}$ Essa terminologia é utilizada pelo grupo Barbatuques, especializado em percussão corporal. Um dos integrantes do Barbatuques, Maurício Maas, tem parceria com o professor Fábio Cintra e foi colaborador do OBARA - Grupo de Pesquisa e Criação em Teatro-Dança, do qual participei. 
proposição dos sons, que segundo o professor colaboraria na "decupagem" da música. Desse modo se deu a desconstrução da música; o ritmo do samba já não era mais reconhecido, apenas a letra podia ser identificada.

Pode-se dizer que a exploração de "Izaura" chegou pronta na Hidráulica, antes mesmo de o espaço da cena ser definido. Na locação, definimos o recorte da cena (enquadramento e ponto de vista), aproveitando uma idéia de ocupação do espaço de uma das jogadoras, e a música foi sobreposta. A criação dessa cena seguiu uma ordem inversa aquela proposta para a criação da maioria das outras cenas. No entanto, o importante foi não ter desconsiderado esses princípios de composição que regeram a encenação. Em outros momentos, sobretudo em algumas cenas de condução do público, notamos que o abandono do modelo de composição desenvolvido na pesquisa dificultou a execução da cena e prejudicou sua realização. $O$ jogo com a letra da música criou uma paisagem, marcada pela polifonia do discurso elaborado a partir da sobreposição de vozes femininas.

O "Coro das Meninas", nome dado à cena referida, constituía uma espécie de coralidade desenvolvida a partir da desconstrução dessa música e correspondeu perfeitamente às expectativas das cenas mais bem sucedidas da encenação. $\mathrm{Na}$ transposição do jogo desenvolvido na sala de ensaios para o espaço, ao invés de ter os pés marcando os pulsos (pois as atrizes estavam deitadas), o som do pulso foi marcado por batidas em uma das máquinas do lugar que produzia um efeito distorcido no som. A sonorização da cena ficava a cargo de Clóvis, que precisava estar muitíssimo atento para não perder o pulso, uma vez que não participava da exploração vocal, mas propunha o terreno sobre o qual as vozes femininas desconstruíam o antigo samba. A atmosfera criada pelo som percussivo retirado daquele canto de máquina remetia a um lounge desconfortável. Apesar do oxímoro presente na descrição, a imagem das mulheres deitadas no chão, realizando movimentos repetitivos era repleta de sensações desagradáveis, em decorrência da temperatura do chão, muito fria. Nos bastidores, os jogadores diziam que nessa cena ouviam o grito das mulheres com tumores no útero, desenvolvido a partir do trabalho com substâncias cancerígenas utilizados nas fábricas. Embora nada disso fosse explicitado na cena, essa era a intenção das atrizes, agindo como trabalhadoras de uma fábrica, conotação percebida na própria Hidráulica. 
Outro exemplo de música desconstruída foi aquela retirada do filme São Paulo S/A, a música tema criada por Cláudio Petraglia. No início da encenação ela era cantada (apesar de ser instrumental) pelo grupo, disposto em linha na frente de um dos portões da Hidráulica. A cena intitulada "anunciação das regras" começava com um coro afinado, que aos poucos ia recebendo intervenções de um ou outro jogador no sentido de descompô-la. Enquanto cantava, o coletivo aproxima-se do público, chegando até ele totalmente ruidoso, com tosses e barulhos estranhos invadindo a música.

No final da encenação, a música era retomada, como fechamento do ciclo, mas dessa vez os tubos de ventilação serviram de alto-falantes para a emissão sonora. A musicalidade foi criada da relação íntima com o espaço, os tubos de ventilação serviam como instrumento de percussão e também como amplificares da voz de uma das jogadoras. O modo pelo qual a faixa de som se relacionava com a imagem reafirmava a dramaticidade da cena. É bom lembrar que mesmo reconhecendo a construção de uma cena pós-dramática ou que revê o dramático, reconheço a existência de estilhaços de drama nos seus fragmentos. Enquanto houver ação, ainda que identificada numa pequena cena, na esfera da micro-análise (no estilo de interpretar, por exemplo), podemos reconhecer drama. No entanto, o fato de a organização macro da obra não corresponder ao ideal do dramático só evidencia as células dramáticas despontadas nos fragmentos de cenas.

A cena final de ISAURA S/A tinha pretensões de se apresentar de forma grandiosa, ou antes, citando grandiloqüências. A linha da anunciação das regras do início da encenação, de forma semelhante, também pretendia instaurar no espectador um clima espetacular, mesmo que o tempo estendido da caminhada dos jogadores em linha, desconstruindo seu coro, apreendesse a atenção do público pelo estranhamento. Considero que as cenas de abertura e fechamento propuseram um tipo de teatralidade similar. Ambas revelavam sua teatralidade como em um close, pois os aspectos teatrais, artesanais, frágeis do teatro estavam escancarados. Não havia nesses dois momentos a intenção de que as cenas parecessem cinematográficas, pois citávamos o cinema de intenção teatral. Vale a pena falar mais uma vez na câmera fixa de Glauber, explorando as entradas e saídas do enquadramento realizadas pelos dois atores, o espaço in e o espaço out, o dentro e o fora. A cena final em que 188 
a música tema era retomada já foi analisada aqui (no cap. 3) como exemplo de estoque de imagem, proveniente do filme "o Dragão da Maldade contra o Santo Guerreiro". Se na anunciação das regras, o movimento dos atores saindo da Hidráulica causava uma impressão de zoom in para quem observava, pois o plano geral da linha tornava-se gradativamente primeiros planos dos rostos dos atores, a caminhada final revelava-se como zoom out, pois os atores se distanciavam cada vez mais do público, dessa vez saindo do galpão e deixando os espectadores do lado de dentro.

\section{Coleção dos Jogos do Olhar - voz, música e ritmo}

A seguir, apresentaremos alguns jogos selecionados para o estudo da voz e da musicalidade. Tais modalidades de jogo, ainda que se voltem especialmente para o "ouvir", têm papel capital na atribuição de um estado de atenção e prontidão dos participantes. Eles foram propostos por Maurício Maas, integrante do grupo de percussão corporal "Barbatuques", na ocasião em que desenvolveu atividades com OBARA - Grupo de Pesquisa e Criação em Teatro-Dança.

\section{Tempo e contratempo:}

Seguindo a mesma lógica do Jogo da flecha da atenção, no qual o grupo está em roda e os jogadores lançam flechas (palmas) uns na direção dos outros, propõe-se que o grupo, antes de iniciar o jogo, defina um pulso comum, marcando-o com os pés. No primeiro momento os jogadores buscam lançar as flechas marcando o pulso, ou seja, no tempo forte, e num segundo momento, lançá-las no contratempo, o tempo inverso, contrário ao pulso, que corresponde à metade desse intervalo rítmico. É importante que os jogadores mantenham o pulso dos pés continuamente, pois eles são a garantia de que não perderão a freqüência comum.

Quando os jogadores têm dificuldade em acertar o tempo ou contratempo, experimentamos marcar o pulso produzido pelos pés juntamente com palmas, marcando o tempo e depois o contratempo. 
Propus como jogo de atenção, depois que o Coletivo já estava familiarizado com o tempo e o contratempo, o desafio de se lançar 8 palmas no tempo, 8 no contratempo; 4 palmas no tempo, 4 no contratempo; 2 palmas no tempo, 2 no contratempo e 1 palma no tempo, 1 no contratempo. Inicialmente, parecia impossível realizar a proposta, mas com o treino constante, o Coletivo realizava uma vez contando alto, em conjunto, e outra vez contando silenciosamente.

\begin{abstract}
Seqüência Minimal:
Todos os jogadores em roda, marcando um pulso com os pés. Cada jogador tem dois ou quatro tempos para explorar uma sonoridade. Um jogador por vez propõe uma seqüência de sons, rítmica ou melódica. Logo após cada proposição, todos os jogadores a repetem juntos, como se fosse um eco. Depois de todos terem definido sua seqüência, um jogador realiza sua seqüência de sons e a repete continuamente. O próximo jogador da roda sobrepõe sua seqüência à do jogador anterior e assim sucessivamente, até que todos os sons sejam sobrepostos. É fundamental que os jogadores mantenham a atenção na pulsação marcada pelos pés, pois ela é a base sobre a qual todos jogam. Em seguida, do primeiro ao último, os sons vão sendo excluídos, até que o grupo retome o silêncio inicial da roda, marcado apenas pelo pulso dos pés.

No caso de "Izaura", trechos da letra da música serviram de mote para a exploração da sonoridade. Aos poucos esses trechos eram sobrepostos, e depois, excluídos um a um. O professor Fábio propôs, aprofundando a pesquisa sobre a musicalidade, que os jogadores variassem o volume, a duração dos sons dentro do intervalo concedido (2 ou 4 tempos) e a altura dos sons produzidos (do grave ao agudo). Essas indicações revelaram outras tonalidades à desconstrução da música, que ainda não tinham surgido no jogo.
\end{abstract}

\title{
3. Arquitetura como locus significativo: iluminação, fotografia e figurino
}

"A luz modela o espaço. Sem luz não há espaço"

Bob Wilson 
No presente item trataremos de alguns elementos da composição teatral que colaboraram para transformação do Centro de Ensaios de Máquinas do Laboratório de Hidráulica em um locus significativo, um Centro de Ensaios de Cenas Teatrais. Os elementos destacados são a iluminação, a fotografia e o figurino. A iluminação teve papel central no jogo de esconder e revelar o espaço, recortando com precisão nossos "enquadramentos" teatrais. Pode-se dizer que com a iluminação do espaço há o fechamento de um ciclo aberto no início do processo criativo, com o jogo de enquadramentos do espaço. Nesse jogo selecionávamos enquadramentos a partir de pontos de vista determinados, com a ajuda de uma máscara de papel. Ao apresentar as cenas publicamente, a iluminação, aliada aos recortes já encontrados na arquitetura, cumpria o papel da máscara que recortava o foco do olhar.

Os leitores atentos terão percebido que em nenhum momento, em se tratando de espaço, referimo-nos a cenários. A idéia era justamente essa, encontrar arquiteturas que inspirassem a concepção do teatro, sem a necessidade de cenários sobrepostos. Saindo da sala à italiana, buscamos espaços que pudessem ser tratados como significantes e, desse modo, não seria preciso criar um lugar onde os jogadores circulassem: o lugar estaria dado. A arquitetura teve um papel central na pesquisa, uma vez que os próprios recortes sugeridos por ela ou percebidos nela pelos envolvidos na criação, desvendaram seus segredos, suas potencialidades significativas. Mesmo sem definição clara do significado dos espaços recortados, como por exemplo, um hospital, um elevador, o tratamento do espaço pela iluminação ou pela atuação dos jogadores delimitava a área de jogo. Portanto, a arquitetura constituía-se como um significante aberto, próximo do conceito de Roland Barthes, um significante obtuso e não óbvio como nos exemplos citados acima.

O espaço da Hidráulica foi tomado como significante flutuante, passível de ser lido como muitos lugares e ao mesmo tempo, nenhum. O caráter múltiplo dessa locação como amontoado de máquinas encontra correspondência na descrição do estúdio de cinema da UFA, do texto já citado "O Mundo de Calicó". Assim como o estúdio, a Hidráulica colecionava modelos físicos reduzidos que serviram para fins específicos, mas, tomada em sua totalidade, ela era uma coleção de peças de vários quebra-cabeças. Depois de 
receber todas essas superposições, esse lugar versátil e incompleto apresenta uma multiplicidade de significações.

Sem definir com precisão esse "onde", a leitura que se fazia dessa arquitetura na qual se inscreve uma prática de colagem-bricolagem (corpos, iluminação, figurino) era de locus. A definição de locus, do dicionário, é "lugar específico em que um gene se localiza no cromossomo" (HUAISS, 2001, p. 1777). Excluindo a parte biológica, traduzimos o verbete como lugar específico, ao qual podemos acrescentar local, posto, localidade, região, habitação, morada, ocasião, ensejo, madre, útero (retirados do verbete "lócus"). Todas essas designações servem para evidenciar a finalidade desse espaço tomado como locação, ora num sentido geral (localidade), ora estável (morada), ora transitório (ensejo), ora de geração (útero). Todos os sentidos destacados revelam a apropriação realizada na Hidráulica, um locus significativo, onde residiam, por hora, cenas transitórias geradas a partir da observação desse lugar.

Ao falar de iluminação, fotografia e figurino, como propõe o título desse item, voltamos a tratar a composição da imagem, apesar de não desconsiderarmos a paisagem sonora também relevante na composição da imagem e vice-versa. A inclusão da fotografia nessa discussão abre um parêntese para se pensar na função da fotografia no cinema. Sabemos que o cinema se aproxima do processo fotográfico por uma questão material: o filme é uma película que se revela assim como uma fotografia. É claro que não estamos falando da fotografia e do cinema digitais. O que nos interessa é lembrar a função de um diretor de fotografia no contexto cinematográfico do qual ele não foi excluído, mesmo com o advento das novas tecnologias digitais. Seu trabalho, juntamente com o diretor de arte, inclui a seleção e a aprovação da locação, da câmera, das lentes e da iluminação, além de acompanhar o processo de revelação da película. Traduzindo para o contexto teatral, em que o material é o evento cênico em si, também podemos dizer que fotografia e iluminação caminham juntas, na seleção e aprovação do espaço, dos recursos utilizados para a iluminação, no que se refere às condições técnicas e ao desenho da luz. É importante observar que no caso desse tipo de teatro, em espaço não tradicional, em que não há cenários sobrepostos, a função do diretor de fotografia ganha proporções de um arquiteto das cenas. 192 
Paralelamente a essa atividade de composição do espaço, podemos destacar a função do figurinista, que veste os corpos presentes em cena, do mesmo modo que a iluminação "veste" a arquitetura.

No caso da Hidráulica, compondo a equipe técnica e, mais propriamente, a direção de arte da encenação (da qual não me sinto excluída), contei com três colaboradores muito especiais: Djöh Wakabara, Renata Velguim e Taty Kanter. Cada um deles era responsável por uma função específica (figurino, fotografia e iluminação, respectivamente), mas juntos integravam a equipe de suporte à lapidação das imagens criadas pelos jogadores. Observadores atentos, os três buscavam meios para evidenciar de maneira precisa cada detalhe das cenas.

Por ordem alfabética, apresentaremos tais colaboradores e as condições nas quais o trabalho foi desenvolvido. Em seguida, alguns estudos de casos (cenas escolhidas) darão continuidade à nossa reflexão.

Jornalista de moda e interessado por cinema e teatro, Jorge Wakabara, o Djöh, envolveu-se profundamente com o Coletivo, desde a Mostra de filmes, a qual acompanhou de perto. Assim que chegamos à Hidráulica, Djöh iniciou uma pesquisa de cores possíveis para a composição dos figurinos, cuja definição aconteceu em parceria com os atores. Pela quantidade de informações contidas no Laboratório, optamos pela cor branca como base para todos os figurinos. Somente dessa maneira os corpos poderiam ser revelados naquela profusão de tubos verdes, cáquis, cinzas dos concretos e sujeiras das máquinas. Sabíamos que, aos poucos, os brancos pareceriam mais beges, pela poeira agregada, mas ainda assim consideramos o branco uma boa opção.

$$
\text { (protocolo de Larissa Alvanhan) }
$$

"Antes de começarmos o aquecimento, aproveitamos a presença do Djöh para acertarmos os figurinos. Foi a primeira vez que eu, Júlio e Juliana passamos pelos olhares criteriosos de Djöh. Foi interessante a proposta trazida pela Ju de usar amarelo nos figurinos. Apesar de termos que fazer algumas adaptações, parece que já fundamentamos a nossa indumentária"

Outras cores também foram exploradas; inicialmente o vermelho, por ser complementar ao verde e por isso destacar-se bastante. Com o passar do tempo surgiram complementos em tons de roxo, lilás, laranja e amarelo, uma 
vez que a composição da vestimenta aconteceu ao longo de todo o processo de ensaios. Vale ressaltar que o figurinista partiu de propostas trazidas pelos jogadores, as quais eram submetidas ao seu julgamento e às suas sugestões. Demos preferência a estruturas mais próximas do corpo, valorizando as silhuetas, já que ao longe as pessoas poderiam tornar-se meros pontos brancos. Com a chegada do inverno, outras peças foram acrescentdas, chegando-se à composição de um guarda-roupa para cada jogador e não apenas um figurino. Por questões de cuidados com a saúde dos participantes, adotamos a versão inverno dos figurinos durante a temporada (maio e junho de 2008).

Renata Velguim é estudante da Faculdade de Arquitetura e Urbanismo na USP e tem se aproximado cada vez mais do universo teatral, realizando fotografias e cenários, por se interessar por esse diálogo entre as artes. Fotografou todos os espaços explorados durante a peregrinação na busca por uma locação e acompanhou todo o processo criativo depois que nos instalamos na Hidráulica. Os jogos do olhar de Renata puderam ser apreciados ao final de cada apresentação, em uma pequena exposição realizada com algumas fotografias ampliadas das cenas de ISAURA S/A. Todas as fotografias incluídas nesta dissertação também são de sua autoria, assim como os cartazes da segunda produção das Sessões de Cinema ${ }^{37}$, do Workshop e da encenação ISAURA S/A. Suas fotografias nos revelaram a beleza das imagens que surgiam em cada um dos locais ocupados, além de acentuar a riqueza de contrastes surgidos a partir dos recortes de luz das cenas. O excesso de preto, na escuridão do enorme galpão da Hidráulica, ressaltava a luz pontual que atraía o olhar do espectador para determinado ponto. Renata tornou-se um ponto de apoio para a iluminadora, atuando durante a temporada como operadora de luz e, muitas vezes, era a responsável por "afinar" a luz dos projetores.

Taty Kanter, por sua vez, esteve presente desde o início do processo criativo, acompanhando a visitação às locações e a escolha do espaço definitivo. Assim que ocupamos a Hidráulica, mais uma vez (pois já realizamos outras parcerias) se viu às voltas com a difícil tarefa de iluminar teatralmente

\footnotetext{
${ }^{37}$ Os cartazes de chamamento para a formação do Coletivo - Jogos do Olhar e das primeiras Sessões de Cinema foram realizados por Marina Takami. 
um espaço que não foi feito para receber o teatro. E mais, com uma verba restritíssima, parte da reserva técnica concedida pela FAPESP. Diante do trabalho com as precariedades, em uma espécie de "estética da fome", Taty teve a brilhante idéia de resgatar nos departamentos da USP, retroprojetores e projetores de slides em desuso devido à chegada dos data shows e projetores de vídeo mais modernos. Se por um lado, a estética desses equipamentos coincidia com as velhas máquinas do Laboratório de Hidráulica, por outro eles também fazem parte da história da escrita do visível. Antes dos projetores atuais (conectados ao computador, que projetam imagens estáticas, textos e vídeos) eram os retroprojetores que projetavam textos, desenhos e imagens impressas em papel transparente e os projetores de slides, fotografias.

Assim começou o garimpo em pequenas salas de almoxarifados, consulta à central de Patrimônio da USP, muita conversa e ofícios para agregar boa vontade à disponibilização de um material sem uso para a Universidade ${ }^{38}$. No total, conseguimos quatro retroprojetores, cinco projetores de slides e um projetor de vídeo antiqüíssimo, que acabamos não usando, pois mantivemos a idéia original de não utilizar projeção de vídeo em cena. A verba da reserva técnica foi essencial para a manutenção desse equipamento, já que a maioria das unidades precisava de pequenos ajustes em cabos e troca de lâmpadas. Ao final da temporada, todo o equipamento foi devolvido funcionando para os departamentos, alguns até com lâmpadas sobressalentes.

Todo esse esforço aconteceu para mantermos os equipamentos parados no mesmo lugar, sem precisar deslocá-los durante a encenação. Isso só foi possível pelo trabalho competente da iluminadora que, além de emprestar todas as suas extensões profissionais, criou gambiarras com luzes dicróicas e refletores de jardim, sempre prezando pela economia e pelo recorte preciso que não revelasse o espaço como um todo. As propostas da iluminadora condiziam perfeitamente com a investigação desenvolvida pelo Coletivo. $O$ desafio proposto a ela relacionava-se à pesquisa de materiais para iluminar

\footnotetext{
${ }^{38} \mathrm{Na}$ Hidráulica, conseguimos três retroprojetores (dois funcionando) e dois projetores de slides (um funcionando). Na Medicina, conseguimos um projetor de slides. Na Odontologia, conseguimos um projetor de slide, um retroprojetor e um projetor de vídeo (não utilizado na encenação). Além disso, pedimos um projetor de slides e um retroprojetor emprestados na ECA e os projetores de slides de duas companhias de teatro: o Engenho Teatral e a Cia. São Jorge de Variedades.
} 
esse espaço nada convencional, valorizando os enquadramentos propostos pelos jogadores.

De um modo geral, a luz da Hidráulica era branca e fria. Distribuída de forma homogênea em toda a amplitude do galpão, chapava as cores, os formatos e, devido às grandes proporções do espaço, fazia perder os corpos de vista. Quando começamos a trabalhar na Hidráulica, saíamos sempre muito cansados de lá, fator que mais tarde associamos também às características da qualidade da luz ${ }^{39}$. Foi assim que começamos a passar a maior parte do período de ensaio na Hidráulica, literalmente, no escuro, deixando a luz iluminar aos poucos o que era visível nas cenas. Para isso, contamos com o suporte de uma caixinha de luz, fabricada pela iluminadora, abastecida por uma bateria recarregável. Essa caixinha não solucionava a iluminação das cenas, mas podia ser considerada um meio de caminho entre a luz geral (do próprio galpão) e a luz a qual chegaríamos com os recursos que conseguimos.

Quanto ao papel da iluminação nesse contexto, podemos dizer que a luz também ocupava o espaço. As funções da luz seriam: recortar, ambientar, favorecer ou ofuscar o espectador, criar passagens ou mudanças de foco (fusão) e conduzir o público. Alguns estudos de caso servirão de exemplo para as funções destacadas acima.

Cabe à luz, portanto, uma função dramatúrgica fundamental na idéia da encenação pós-dramática. A dramaturgia das imagens, do visível sugerindo o invisível. (FORJAZ, 2006, p. 76)

Quando os espectadores entravam na Hidráulica, uma atmosfera estava instaurada, resultante da composição da luz integrada à paisagem sonora produzida nas cenas simultâneas. Cada modelo físico reduzido recebeu um tratamento específico de luz para ressaltar a ocupação que os atores haviam proposto. Nessa entrada na Hidráulica, todas as fontes dessas cenas estavam ligadas, demarcando o terreno inicial que seria percorrido pelo púbico. $\mathrm{Na}$ medida em que o público passava, os modelos que ficavam para trás iam sendo desligados. Durante toda a encenação, havia inúmeras atividades técnicas desempenhadas pelos jogadores e demais colaboradores. Uma equação complexa, que rendeu inclusive um rigoroso roteiro de atividades

\footnotetext{
${ }^{39}$ Para passar tanto tempo na Hidráulica (no mínimo 4 horas por ensaio), era preciso muita disposição física, boa vontade e interesse pela pesquisa. O espaço consumia muita energia de todos, pela amplidão, pela quantidade de escadas e pelo teor do trabalho que realizávamos ali. 196
} 
vinculadas às operações técnicas (nem sempre bem sucedido). Um efeito de luz, em particular, merece destaque. Uma das cenas, desse momento simultâneo, acontecia diante de um dos poços de água; ao invés de iluminar diretamente o rosto das atrizes, a iluminadora optou por iluminar a água. $\mathrm{O}$ resultado podia ser percebido até o teto do galpão, pois a água produzia um espelho que além de iluminar a cena, reverberava pelo espaço, produzindo um efeito aquoso sobre o ferro das máquinas.

Outra cena, considerada exemplar em muitos aspectos, é a "piscina amarela". Nela, o público olhava de longe, através das janelas de um corredor, um modelo posicionado no centro do galpão. Apesar de ser um modelo de uma barragem de água, um dos maiores do galpão, o olhar estaria disperso, se não fosse o recorte claro proposto pela luz. Um refletor de jardim foi posicionado no chão do modelo, valorizando o corredor central da pequena barragem. O nome "piscina amarela" é justificado pela cor amarela ressaltada pela luz. Três atores estavam em cena: uma atriz ocupava, na maior parte do tempo, o corredor central e um casal permanecia todo o tempo nas bordas da piscina. Para o casal, portanto, a luz chegava de baixo para cima (em contraplano), provocando um jogo de sombras que ampliava suas figuras e valorizava o movimento que remetia à morte do dragão do filme de Glauber. A figura que ocupava o corredor recebia a luz também em contraplano (resultando em uma sombra menor que a do casal) efeito que chegava ao auge quando ela simulava beber uma tinta azul. A tinta escorria por seu corpo, colorindo-o, encobrindo seus seios e escorrendo até o chão, não sem antes passar por uma saia de plástico, estrategicamente incluída para que o figurino de base fosse poupado.

A ação (beber tinta) é uma referência a uma das três tentativas de suicídio praticadas pelo bandido da luz vermelha. No filme ele simula beber tinta a óleo vermelha, que escorre de sua boca gerando uma máscara similar aos bandidos dos filmes de faroeste. No filme "Pierrot le Fou" de Godard também, o personagem Ferdinand, antes de cometer o suicídio final, pinta o rosto com tinta azul. Fazendo a paródia da paródia, já que Sganzerla parodiou Godard, parodiamos os dois e propusemos que uma mulher (uma Isaura?) bebesse tinta azul. A opção pelo azul foi tomada após algumas experimentações com o vermelho. O azul complementava a cor amarelada do 
espaço e coloria a atriz de uma cor que não poderia ser associada ao sangue. Falar dos efeitos de luz e das escolhas da direção de arte, de modo geral, não dá conta da descrição da cena, pois as faixas de imagem e som (música de Astor Piazzolla) se complementavam de tal maneira, que apenas a presença diante dela poderia revelar o resultado obtido. Depois de camuflada pela tinta, a atriz caminhava lentamente para trás, deixando o público apreciar o quadro sob o efeito da música. Em minha opinião, todo o tempo para observar aquela imagem era pouco, era uma cena que pedia o estiramento do tempo, exibindose para a contemplação.

Outra cena que merece atenção especial, também analisada quanto à faixa sonora, é o Coro das Meninas; produzida ao inverso, ou seja, primeiro a faixa sonora, depois a faixa de imagem, comprova o vínculo estreito entre as cenas e a arquitetura investigada. Assim que definimos o enquadramento e o ponto de vista, um retroprojetor foi disposto no piso térreo, ao lado da cena, sendo que o público a observava de cima. Taty Kanter posicionou o retro de tal modo, que a luz se prolongava justamente até a última menina deitada no chão, nem mais nem menos. Se o retroprojetor fosse displicentemente colocado no chão, diante das meninas, toda a faixa do andar térreo correspondente ao enquadramento seria iluminada, revelando mais do que o recorte da cena. A inclinação do equipamento, para realizar o foco preciso, auxiliava também a realização de um efeito "aquoso" sugerido pela iluminadora. As operadoras de luz (Renata, Paulina e Damyler, variava) utilizavam conta-gotas para produzir um efeito de trilhos de água que escorria sobre a cena. O elemento água, representativo do universo feminino, perpassava a imagem daquelas mulheres (Isauras?) deitadas no chão, dotando a luz de uma forma particular de movimento, delicado e íntimo.

$\mathrm{Na}$ cena "antifesta", como já explicitado anteriormente, buscou-se instaurar o caos, chegando ao ápice da sobreposição e da montagem, rompendo com as barreiras do enquadramento e deixando o espectador livre para compor seus jogos do olhar, escolhendo o que enquadrar, quando e por quanto tempo. A iluminação desse caos, portanto, colaborou de forma definitiva no rompimento da lógica, pois multiplicava os focos de atenção. 
"Terminamos o aquecimento e partimos para a construção das cenas da Cena-caos. Para mim, foi nesse exato momento, de construção dessas cenas, que percebi como lidamos com poucos aparatos técnicos de luz, ficamos, assim, sujeitos à precariedade. Foi aqui que caí na real do que é fazer uma peça na Hidráulica."

A professora Cibele Forjaz afirma que no teatro pós-dramático "a luz rege o que é visível, ela pode iluminar várias ações ao mesmo tempo, porém de forma diferente, separando e multiplicando os planos de realidade" (FORJAZ, 2006, p.68). O contrário aconteceu na cena "panorâmica": único momento da encenação em que todas as luzes da Hidráulica eram acesas, o que chamávamos de luz geral. Esse momento se dava no final do percurso do público, quando o Laboratório era revelado. Segundo o comentário de um dos espectadores, o local era 'feio' com sua luz convencional acesa, diferente do que acontecia com a iluminação proposta para as cenas.

Outro efeito que merece destaque, no que concerne à iluminação foi uma solução proposta por um jogo com a luz, que se referia também ao filme "Pierrot le Fou", de Jean-Luc Godard. Com um retroprojetor abastecido de gelatinas coloridas, os jogadores criaram ações para a cena da sombra a partir das cores do tecnicolor (vermelho e azul), tal qual aparece nas cenas monocromáticas do filme. Vale ressaltar que essa cena foi a única em que a iluminação propunha cor, pois dispúnhamos de um pano branco como suporte para a cena. Nas demais cenas, a quantidade de informações oferecidas pelo espaço impossibilitava a sobreposição de cores. Ao contrário, o trabalho da iluminação, calcado em luzes de cor branca, destinava-se evidenciar algumas cores do espaço, que eram necessariamente dominantes. Por isso, os demais elementos da composição se adequaram às cores do local, tanto a luz quanto os figurinos encontraram no branco uma saída acertada para não concorrer com a onipotência da Hidráulica.

\section{Encenação e Coletivo - Jogos do Olhar: uma composição paralela}

"A criação não é uma compreensão, é um novo mistério" Clarice Lispector

No presente item ensaiaremos uma reflexão sobre o entrelaçamento final dessas duas composições: a experimentação prática e a configuração do Coletivo - Jogos do Olhar. Diante da premissa de não dissociação de processo 
de aprendizagem e processo de criação teatral, questões relativas à construção do discurso cênico, passando pelo partilhamento das vozes dentro da criação entram em jogo. Para isso, as regras iniciais que nortearam o processo precisam ser resgatadas e observadas com lupa, para haver o real cotejamento dos avanços e entraves decorrentes dessas escolhas. Trata-se de uma análise do processo parcial, obviamente, pois a imparcialidade ou a onisciência são metas inalcançáveis. Procurei ao longo da reflexão dialogar com as outras vozes responsáveis pela construção desse discurso, apesar de mesmo sua existência (do discurso) ter sido questionada.

\section{(Protocolo de Adriane Escher)}

"Para mim, apresentar foi uma mostra de experimentos, não um discurso"

Em relação à construção desse discurso (que insisto, existiu!) tentarei recuperar as discussões acerca da elaboração ou da descoberta dos sentidos imanentes às cenas criadas. Desde o início do processo, valorizamos a prática das duas atividades próprias ao teatro: fazer e ver.

[...] o teatro não é uma atividade, mas duas. Atividade de fazer e atividade de ver. Pode-se objetar que isto é verdadeiro para todas as artes e também para outras coisas. Claro. Mas a especificidade do teatro diz respeito ao fato de que, nele, as duas atividades são indissociáveis e o "teatro" só existe com a condição de que ambas se dêem simultaneamente. (GUENÓUN, 2004, p. 14)

Apesar de no trecho citado o pesquisador se referir ao momento do acontecimento teatral em si, quando ver e fazer são atividades concomitantes e, necessariamente, realizadas por no mínimo duas pessoas diferentes, gostaria de refletir sobre o ver e o fazer no processo de criação teatral. Desde o nome do projeto, Jogos do Olhar, a atividade do ver está ressaltada, contrariamente a certas práticas focadas apenas no fazer, que às vezes inconscientemente, acabam não se preocupando com o espectador e também se abstendo de exercitar a leitura do que se faz. Sendo assim, desde os primeiros jogos (do olhar), exercitamos o ato de ver na proposição de títulos para as fotografias compostas pelos jogadores nos enquadramentos espaciais. O mesmo autor é esclarecedor ao discorrer sobre esse jogo de olhares: o olhar benevolente e, ao mesmo tempo, sedento (Ibidem, p. 148, grifos do autor). 
Uma criança que brinca de teatro (como eu também brincava) brinca de ator enquanto outras, várias outras, brincam de olhar. A necessidade do teatro que se faz é necessidade de jogadores, mas convoca companheiros de jogo para fazerem os espectadores. Assim, do lado da platéia, também são necessários jogadores que ofereçam ao jogo a benevolência de seu olhar.

Denis Guénoun se pergunta, ao longo de todo o livro do qual esse excerto foi extraído, se o teatro é necessário, e em caso positivo, qual seria essa necessidade nos dias de hoje. Como o livro dialoga diretamente com nosso objeto de estudo, permito-me um parêntese para apresentar parte de sua reflexão. $\mathrm{O}$ autor afirma que o teatro não é mais um instrumento que satisfaz as solicitações da imaginação dos espectadores, papel que o cinema teria se apropriado na atualidade. Pontua inclusive o uso recente da palavra "imaginário", que teria a mesma idade do cinema. "O cinema é o tornar-seimagens do imaginário" (ibidem, p. 109). Assim o espectador que quiser ver personagens, identificar-se com eles ou vivenciar a experiência de ser sujeitoespectador da representação deve recorrer ao cinema. O cinema, como já dissemos, realiza com mais eficiência a tarefa de representar o mundo, de causar impressão de realidade. O próprio ritual da sala escura, experiência individual, é um convite para o abandono, o esquecimento, de si mesmo e projeção, identificação com os personagens (e quiçá, atores dos filmes). O autor enfatiza uma mudança nos espectadores de teatro contemporâneos, talvez pelo cinema atender mais plenamente às demandas de identificação e de materialização do imaginário que o teatro. Então, o espectador vai ao teatro ver um espetáculo e não a realidade, ver atores em situação de jogo e ver também o modo como o ator se comporta. Para concluir, ele afirma que o espectador hoje em dia sai do teatro não interessado em fazer o que o herói faz, mas interessado em fazer o que o ator faz. Prova disso é o aumento considerável de pessoas em busca de escolas e cursos de teatro, apesar do visível esvaziamento das salas de teatro.

Após essa digressão ao lado de Denis Guenóun, volto às opções que constituíram as bases do processo vivenciado pelo Coletivo - Jogos do Olhar. A ênfase na prática do olhar acentua uma dinâmica de trabalho que responsabilizava a todos pela leitura das cenas e, sobretudo, pelo 
levantamento das questões de interesse ao coletivo. Esse é o momento de resgatar a construção do sentido da encenação que se construía.

O tipo de composição dramatúrgica que realizamos nesse processo de criação gerou muitos questionamentos nos integrantes do Coletivo - Jogos do Olhar sobre as escolhas da encenação no que se refere à produção de sentidos. A sociedade, de um modo geral, está treinada em matéria de audiovisual para ler estórias, mesmo onde elas inexistem. Hoje em dia, até os comerciais de televisão contam estórias. Mesmo que os jogadores tenham dito que o problema que viam no produto final não era o fato de não contarmos uma estória, considero relevante fazer essa digressão sobre a relação entre os sentidos apontados na cena e o estatuto do texto nessa modalidade de cena contemporânea. O texto, na tradição teatral, é concebido como reservatório de sentidos. A opção pela des-hierarquização do texto, adotando o princípio da parataxe, provoca mudanças na percepção da cena. Quando o texto é disposto ao lado dos demais elementos da cena, coloca-se em risco a rede de sentidos intrínseca a ele.

$$
\text { (protocolo de Júlio Barga) }
$$

"Discutimos um pouco sobre a dramaturgia e refletimos sobre o que fazemos, sobre o que nós estamos falando, a relação entre os fragmentos. Sério? Fragmentos? Mas tudo se

encaixa tão bem em uma ilógica lógica neste neologismo teatral cinematográfico, que embaralha o espectador ao mesmo tempo em que tudo faz sentido ou virá a fazer. Bom, essa foi uma amostra do meu fluxo de pensamento durante a discussão"

Buscamos a seguir analisar a dramaturgia resultante desse processo de composição. Observando a macro-estrutura de ISAURA S/A + 1 Experimento Hidráulico, podemos identificar três ciclos, ao menos do ponto de vista de quem compôs a encenação. Um primeiro ciclo corresponderia às cenas intituladas anunciação das regras (linha inicial), prólogo (dois cães do lado de fora do galpão) e cenas simultâneas (seqüência que apresenta todos os jogadores instalados em modelos físicos reduzidos, manipulando a água dos poços e diante da vidraça, até a primeira aparição dos políticos). Ao final do primeiro ciclo, todas as figuras foram apresentadas, o espaço foi introduzido, assim como o modo de estruturação do discurso: fragmentado e carregado de simultaneidades e sobreposições. Além disso, esse ciclo caracteriza-se pela 
condução do cão, falso narrador que ilude o público fazendo-o crer que será acompanhado durante todo o percurso.

Um segundo ciclo pode ser identificado a partir das "eletrocutadas", pois elas retomam a música de abertura da encenação (retirada do filme São Paulo $\mathrm{S} / \mathrm{A}$ ), pontuando a abertura de outro ciclo de acontecimentos. Esse ciclo, de forma indireta e nada clara, se encarrega de apresentar elementos sobre Isaura: uma cidade, uma mulher, uma coleção de dados sobre o mundo ou o que acontece na cabeça de Isaura, o que ela vê. Algumas hipóteses que poderiam aparecer, pois nenhuma dessas escolhas foi efetivada pela encenação. Vários fragmentos são apresentados nos quais não havia nenhuma referência à Isaura, encerrando-se na "antifesta", uma síntese dos fragmentos alheios à Isaura.

Novamente as mesmas figuras que selaram a passagem do primeiro para o segundo ciclo reaparecem e conduzem o público até a "panorâmica", cena em que se descreve Isaura, uma cidade que se move para o alto. Nesse ponto a musicalidade é mais evidente do que o assunto do qual o texto trata. $O$ desvelamento do espaço como um todo transforma a rítmica contida no texto em trilha sonora para movimentar o olhar. Nessa altura, o espectador podia observar o espaço todo, sentado em cadeiras confortáveis (pela primeira vez). Como o jogo instaurado entre os atores ressaltava a fragmentação do discurso pela alternância das vozes, o sentido do texto era apenas sumariamente captado. A visão do espaço como um todo era mais interessante ao espectador do que a escuta do texto, onde talvez ele pudesse encontrar algum sentido para o nome da encenação. O jogo até esse momento operava no nível da imagem, do revelar e esconder partes do espaço, observado de vários ângulos de visão e não no nível da fábula, por isso, provavelmente, o espectador não estava interessado em saber quem era Isaura. Mesmo sabendo que o texto versa sobre a cidade de nome Isaura, nesse ponto o espectador já tinha perdido o interesse pela fábula.

Desse ponto em diante, podemos demarcar a ocorrência de um terceiro ciclo, em que alguns fios narrativos são retomados: os políticos, a moça presa no "aquário" e a outra que dançava na "piscina de musgo" (todos eles presentes nas cenas simultâneas do início). Além disso, a noiva mata a figura masculina que vivenciou todos os esboços de triângulos amorosos. A figura do 
cão também reaparece para conduzir os espectadores até a cena final, que retoma a mesma linha da anunciação das regras, mas desta vez vista de dentro do Laboratório, ou seja, com os atores de costas para o público.

Sem pretender explicar a encenação ou dotá-la de algum sentido especifico, verificamos o quanto a estrutura acima não constrói uma narrativa, nem linear, nem fragmentada. O roteiro encontra, apenas na sua geografia, motivos para se justificar. Podemos dizer que o primeiro e o último ciclo têm tamanhos similares e correspondem à entrada e à saída do galpão. Nesses dois momentos, há alguns temas que são retomados, como se compuséssemos música. O discurso cênico se assegura na organização espacial do jogo.

(Protocolo de Daniel Cordova)

"Como se dá a construção de sentido em um processo criativo que parte da forma? A obra que se propõe a múltiplas leituras não parte de uma leitura convergente?"

Apesar da dificuldade de se analisar um objeto cênico do qual participei criativamente, desconfio que o interesse em diminuir a primazia do texto na composição, acabou recaindo sobre o que os teóricos franceses identificam como a dinastia da imagem. Reconheço os limites dessa opção e os riscos que se corre ao assumi-la, mas entendo que a radicalidade no tratamento das imagens tenha se tornado justamente o diferencial dessa encenação. Escolher enfatizar a imagem e lidar com o texto como materialidade visual e sonora, eclipsa o sentido do texto. Quando o texto não se encarrega de apresentar parâmetros para o entendimento da experiência vivenciada, as demais atribuições de sentido também ficam comprometidas. Não nos referimos aqui a uma mensagem, mas ao nível de reflexão que a encenação se propõe. Ela não atende às expectativas de reflexão e problematização dos "temas" sugeridos pelas imagens e, igualmente, ela não oferece referências ou ferramentas para a discussão. Esse teatro de imagens não propõe assuntos esmiuçados, não esclarece pontos de vistas sobre a realidade, não expõe dois lados da questão, não indica a boa e má atitude a ser tomada. A provocação é escancarada pela imagem, sem propor atitudes direta ou explicitamente políticas.

Diante do teatro de imagens de Bob Wilson, o professor francês Frédéric Maurin opõe duas vertentes de reações, uma relativa ao fechamento e outra à 
abertura. "[A imagem wilsoniana] é percebida tanto como uma poderosa forma de exclusão, quanto como um estímulo do livre jogo das faculdades mentais" (MAURIN, 2004, p. 63, tradução da autora) $)^{40}$. Uma voz propaga a imagem como fascínio torpe, abismo, paralisia do olho ou sedução fácil. Outra voz replica que a imagem é pensamento, percepção de uma latência, de um prazo, de uma aura. Maurin também coloca em jogo a questão do imaginário, dispondo vozes conflitantes que afirmam que as imagens o bloqueiam ou o produzem. E coloca ainda, uma terceira voz em cena, de um brechtiano, que sem rodeios rejeita tais imagens com a justificativa de que elas conduzem à passividade e à renúncia de julgamentos. Outro apontamento do autor se refere ao fato do teatro de imagem pretender dizer tudo, ou antes, tratar de tudo, o que a seu ver, resultaria em um teatro que não diz nada. Ou melhor, diz apenas que é contrário ao teatro centrado no texto. Mais adiante no texto, o autor diz:

No entanto, já Heiner Müller, mas também Roger Planchon antes dele, e Bernard Sobel e Bernard Dort depois, reconhecem o poder [das imagens] de ativar o espírito como um catalisador, de suscitar um espaço propício à reflexão: um espaço mais arquitetônico que histórico, é verdade, e uma reflexão mais estética que política, mas esse espaço descreve uma abertura, e essa reflexão, uma liberação. (Ibidem, tradução da autora $)^{41}$

A contraposição apresentada por Maurin estimula a reflexão, levando os leitores a considerar leituras divergentes sobre os pensadores e artistas que se interessam pela imagem. Para o presente estudo, o autor colaborou para o questionamento de algumas medidas adotadas na composição de ISAURA S/A e, ao mesmo tempo, para a reafirmação das influências dos teatros de imagens na configuração dessa encenação.

No contato com o objeto artístico criado nas imediações da Hidráulica, a sensação era mais forte que o sentido. O confronto da arquitetura voltada para fins científicos e todos os aparatos artísticos que a habitaram, devolveram para

\footnotetext{
${ }^{40}$ Do francês: "[l'image wilsonienne] est perçue tantôt comme une puissance d'exclusion, tantôt comme une stimulation du libre jeu des facultés mentales. "

${ }^{41}$ Do francês: Pourtant, Heiner Müller déjà, mais aussi Roger Planchon avant lui, puis Bernard Sobel et Bernard Dort après, lui reconnaissent le pouvoir d'activer l'esprit comme un catalyseur, de susciter un espace propice à la réflection : un espace architectural plutôt qu'historique, il est vrai, et une réflexion esthétique plutôt que politique, mais cet espace décrit une ouverture, et cette réflexion, une libération.
} 
o olhar um resultado estranho, de choque de sentidos, onde fortes sensações tomavam lugar. Muitas vezes, ao tentar responder sobre o que a peça falava, os jogadores se colocavam a discorrer sobre os procedimentos adotados, sobre as escolhas formais, estéticas, em detrimento dos assuntos que poderiam estar embutidos naquele contexto. Uma vez, conversando com um amigo poeta, ele me disse que no subterrâneo de alguns poemas corre uma prosa, como se fosse necessário manter em algum lugar uma estória ou um sentido escondido para se justificar a fragmentação e a sinestesia encontradas no poema. No subsolo de seus poemas, contudo, ele não esconde uma prosa, não há um chão seguro, estável. O incômodo está justamente em se mover sobre esse chão movediço, que não atende às expectativas dos espectadores, nem mesmo dos jogadores. 


\section{ANEXO IV}

1. Roteiro Hidráulico VIII (versão final)

2. Mapa para se chegar à Hidráulica

3. Cartazes da encenação

(fotos e arte de Renata Velguim) 


\section{ANEXO IV}

\section{ROTEIRO HIDRÁULICO VIII - ISAURA S/A + 1 Experimento Hidráulico}

\section{(roteiro final de cenas e textos)}

Os textos serão apresentados em letra reduzida e as indicações e descrições das cenas, com a letra padrão utilizada no texto. Como mencionado anteriormente, utilizamos os nomes dos atores para indicar quem diz o que, uma vez que não houve construção de personagens, mas esboços de figuras, sem identidade definida. Apenas algumas exceções dentre essas figuras receberam nomes de personagens, ainda que sua composição não seja diferente das demais figuras que emergiram do espaço da Hidráulica.

\section{PREFÁCIO:}

O Coletivo - Jogos do Olhar tem o prazer de apresentar ISAURA S/A + 1 Experimento Hidráulico. Vocês sabem, esse espaço é palco de muitas experiências hidráulicas. ATENÇÃO! Fique atento ao seu corpo, disponibilize-se para esse Experimento! Vocês poderão nos acompanhar desde que tenham assinado o termo de compromisso, responsabilizando-se por qualquer distração. Seja um verdadeiro bombeiro, esteja pronto para apagar incêndios de verdade. Médicos e enfermeiros nem sempre estão disponíveis. Tem algum médico aí hoje? Detalhe importante: Mantenha o celular ligado, atenda seu telefone, não se desconecte do mundo, comunique-se! ATENÇÃO! O jogo permanece imperfeito se é usado como um produto acabado. Bom Experimento!

2. ANUNCIAÇÃO DAS REGRAS: Linha inicial. Jogo com a música do filme São Paulo S/A. Apresentação do Coletivo. Cão conduz o público.

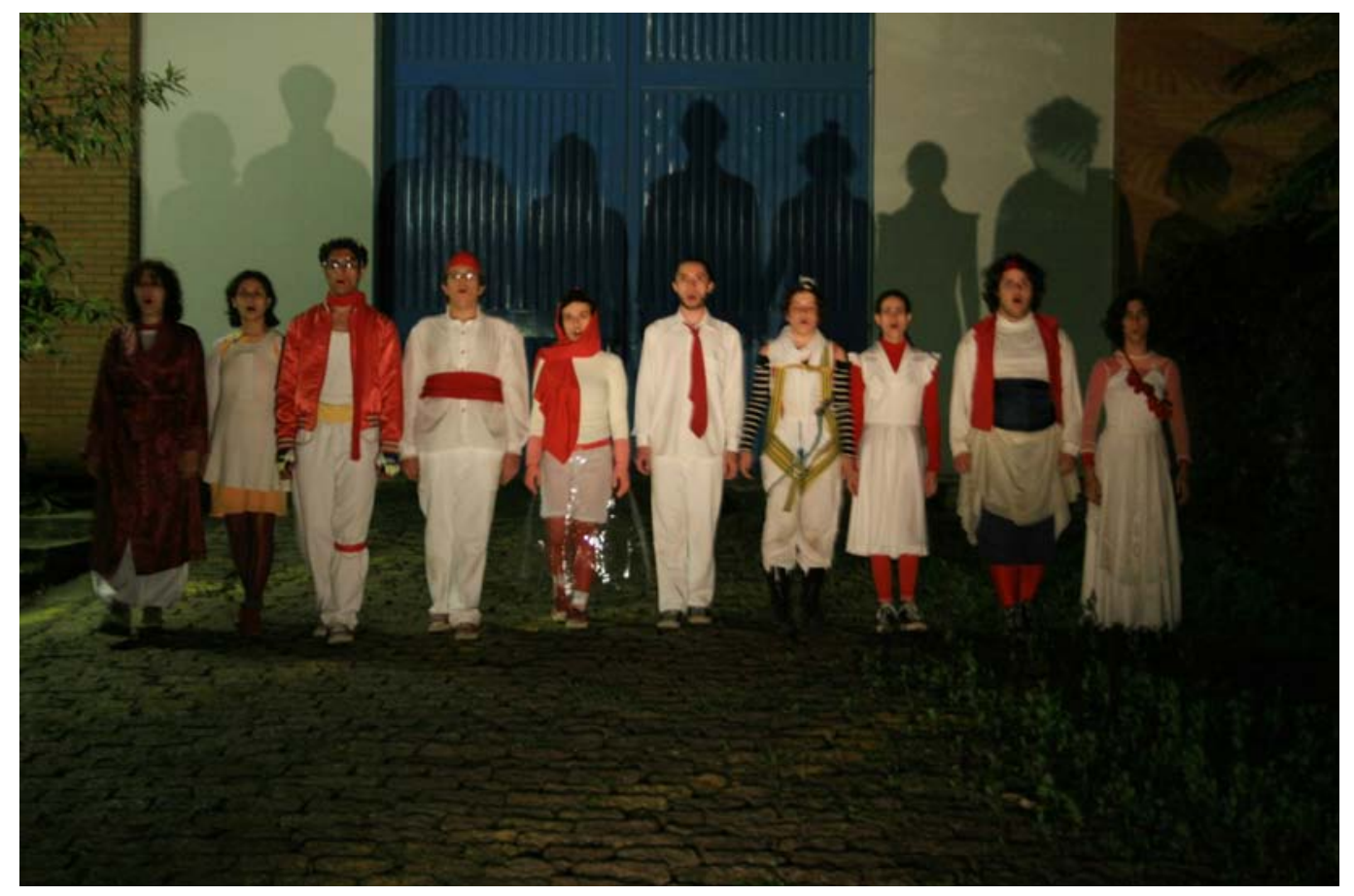




\section{PRÓLOGO: Jogo dos cães: Katia e Anna.}

Anna - Aqui, nesse amplo laboratório hidráulico apresentaremos os elementos retirados do mundo. As cenas são muitas...

Katia (interrompendo) - Parecem as pedrinhas de um mosaico.

Anna - Uma multidão de grãos de imagens, oriunda de múltiplos lugares permanecem desunidas.

Katia - O procedimento é rápido, em vez de deixar o mundo nesse estado quebradiço, as coisas são reintegradas ao $3^{\circ}$ mundo.

Anna - As coisas são retiradas de seu contexto e são reintroduzidas, não são para serem levadas a sério.

Katia - Cada acontecimento foi preparado isoladamente e instalado em seu lugar.

Anna - Os personagens, assim como os acontecimentos, não pertencem ao mundo, mas ao $3^{\circ}$ mundo.

Katia - É um lixo sem limites senhoras e senhores.

Anna - Trata-se de um faroeste do $3^{\circ}$ mundo.

Katia - Qualquer semelhança com fatos reais ou irreais, pessoas vivas, mortas ou imaginárias é mera coincidência.

4. CENAS SIMULTÂNEAS: Entrada na Hidráulica, narração do cão enquanto as cenas são apresentas.

A preparação para o movimento inicia-se antes da nossa decisão de mover algo. Essa preparação associa-se à atividade cerebral e forma o potencial de prontidão - espécie de onda elétrica discreta que pode ser medida acima dos lobos frontais, e que começa um terço de segundo antes de um movimento ser observado. Há quem ligue o estado de prontidão às narrativas subconscientes ou ao narrador dentro da nossa cabeça: nossos olhos seriam câmeras de televisão que projetam as suas imagens para dentro do nosso cérebro. Quem assiste às imagens lá dentro? Um narrador, é claro, uma espécie de miniatura de nós mesmos. Um homúnculo embutido no nosso cérebro que fala para nós com uma voz que apenas nós ouvimos. É preciso desconfiar desse modelo de miniatura de eu de plantão na mente humana. 


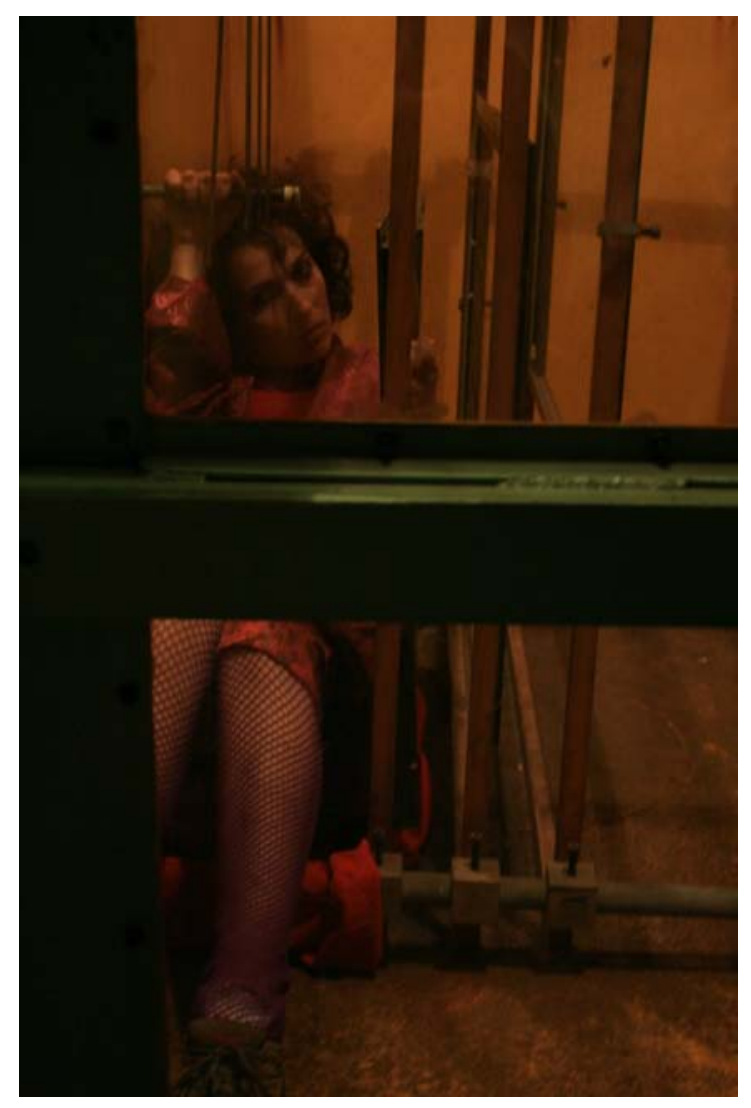

Aquário: Larissa realiza ação que será desconstruída no final. Espaço do simulacro, da criação, da manipulação, não da realidade.

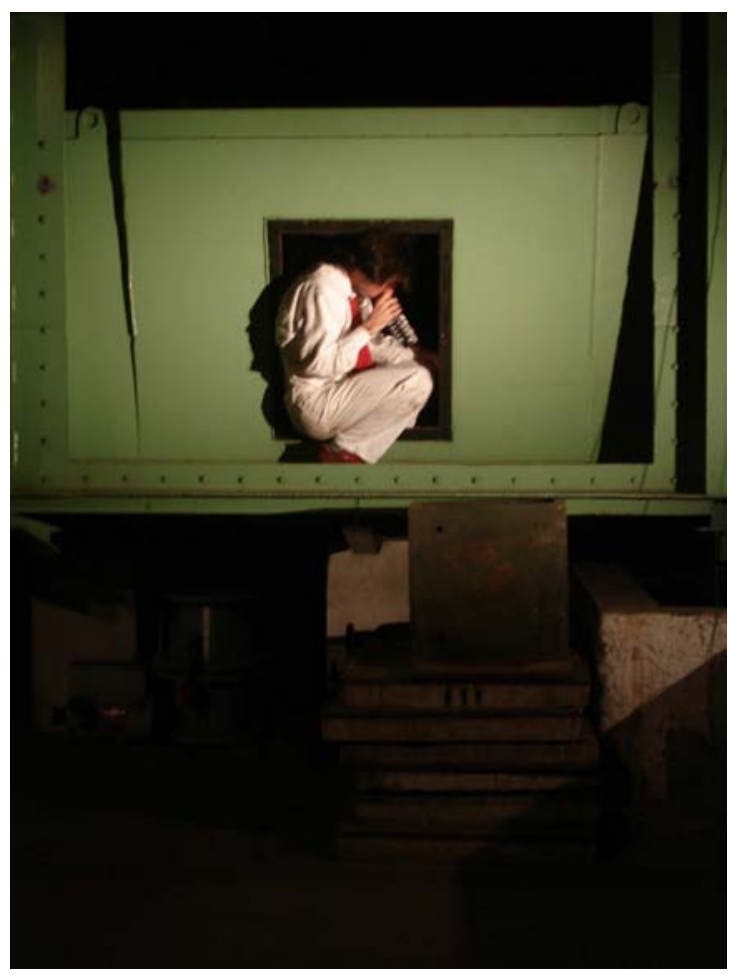

Daniel no quadrado busca se encaixar, depois fica de pé. 


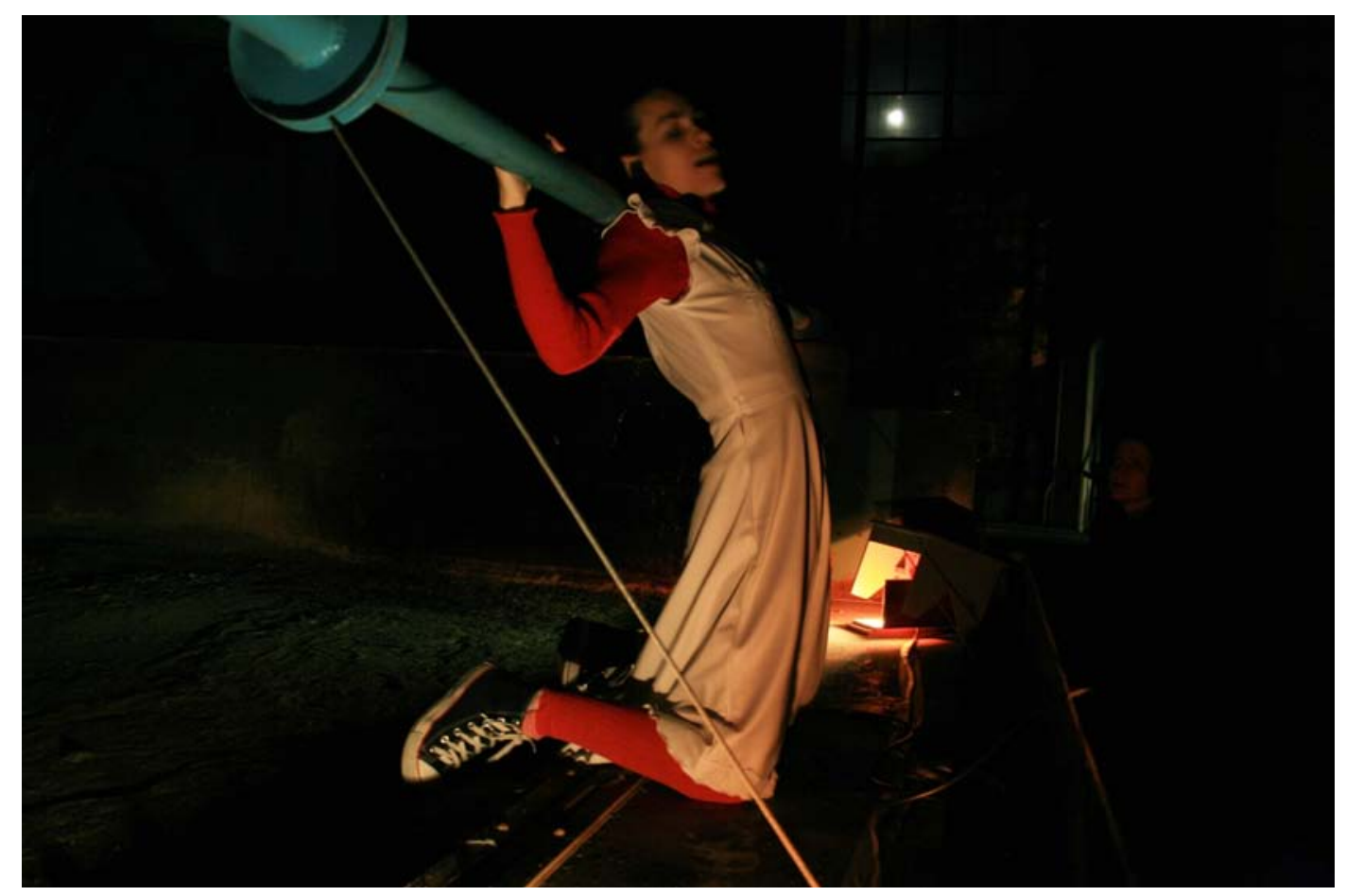

Katia na piscina de musgo emite sons da dança indiana.

Paula nos baldes e Adriane com uma garrafa molhando os cabelos.

Quero virar pedrinha de gelo. Me faz pedrinha de gelo?

Esse final de semana vou me dedicar aos boçais. Nasci para os boçais.

Clóvis e Juliana na vidraça.

Paula joga água na janela.

Júlio no cano verde: discurso do político J. B. da Silva. Júlio faz o gestual do político, mas a voz que ouvimos é do Felipe.

E afinal das contas, o que é o café?... Tá certo, o que ele ainda pesa na balança. Sem ele, o Brasil já estaria perdido. Mas o café é o presente, o futuro está aqui, Carlos. É a indústria que vai decidir. É o aço, o petróleo, nossas máquinas, nossos automóveis, nossos tratores. E quem é que diz a última palavra no assunto? Quem é que comanda? Quem é que puxa tudo isso pra frente? Me diga? É São Paulo, meu velho! É São Paulo! Essa terra de gente que trabalha. Somos nós que impulsionamos o Brasil, somos nós o motor. 
São Paulo cresce e não parará de crescer. Você se lembra alguns anos atrás, quem pensava que o Brasil ia fabricar automóveis? Quem acreditava que de um dia para outro surgiria tudo isso que você vê na sua frente...? Duas mil indústrias de autopeças como a nossa, mais de duzentos mil veículos por ano, assim, de uma hora para outra, já pensou?

5. ELETROCUTADAS: Paula e Adriane emitem sons da música inicial, luz de velas nos pés. Condução do público com Katia explorando a palavra:

Pacientemente. Pacientemente.

Pacientemente. Pacientemente.

\section{Cano verde - em contra-plongée. Katia no chão e Daniel chamando} por Isaura, de cima do volante.

Isaura, cidade que se move para o alto, com suas cavernas e galerias, cresce e não parará de crescer. Isaura vive nas profundidades, no lago negro que nutre as veias subterrâneas. Isaura vive nos baldes, nas roldanas, nas tranquetas, nas alavancas, nas muralhas, nos castelos, nas fortificações, nas trincheiras e nas fossas. O mundo certamente reaparece aqui, sim, todo macrocosmo aparece reunido nessa nova Arca de Noé. Quando a gente não pode mais, a gente avacalha, avacalha e esculhamba. Porque sozinho a gente não vale nada.

Anna pergunta, posicionada atrás do público, no alto, vista também em contraplongée, propondo uma relação de campo e contracampo para o público.

E daí?

\section{Katia e Daniel respondem:}

E daí que a gente avacalha, avacalha e esculhamba.

7. RECOMEÇAR: Anna da plataforma II, com uma luz pontual no rosto, masturbando-se.

Recomeçar, trabalhar, mil vezes tentar ser um homem, trabalhar pra tudo, esquecer Ana, apagar Luciana, não lembrar senão do trabalho, das (cinqüenta) obrigações diárias. Lembrar somente das (chateações diárias) do trabalho. Lembrar (...) engrenagens. $E$ mais outra. E mais outra. E mais outra. De uma engrenagem. E depois do eixo. Que deve ser entregue dentro do prazo estabelecido. Mil vezes recomeçar. Recomeçar de novo. Recomeçar sempre. Esquecer Ana. Apagar Luciana. Lembrar-se das cinqüenta obrigações diárias do trabalho.

Som alto interrompe a finalização do discurso de Anna, produzido por um salto de Katia e Daniel numa placa de ferro no chão. Os dois atores, enrolados em uma mangueira, convidam o público a acompanhá-los.

Sozinho a gente não vale nada, então vamos ficar bem juntinho. Vem, fica pertinho.

Tem um monte de gente lá longe. Sozinho a gente não vale nada, vamos ficar juntinho. Vem? 
8. FOGUETE: Clóvis sobre o patamar do foguete. Adriane no espaço abaixo dele. Paula diz, usando um balde como ressonador de sua voz:

Dunas. Ruído de lancha. Cobrindo a praia e entrando pelo lago, um pontilhão, onde Carlos e Ana passeiam. Conversam.

As falas de Carlos são ditas por Clóvis, as de Ana são ditas por Adriane e as didascálias por Paula:

Carlos - Existe sempre um porto. É um porto ainda quando não é.

Ana - Carlos, o que é esse lugar?

Carlos - Era... Hoje não é mais.

Ana - Carlos, o que era este lugar?

Carlos - Era um porto, um porto de areia.

Ana - Areia, barcos. Os barcos, o que eram?

Carlos - Os barcos não eram barcos. Os barcos eram batelões. Os batelões eram para a areia. A areia era para o vidro. Hoje a areia não é mais para o vidro. Hoje não tem mais vidro. Hoje não tem mais.

Latidos apavoram Ana.

Ana - Carlos!

O cão persegue Ana que abraça Carlos.

$\mathrm{Na}$ imensidão do lago, uma canoa, Carlos rema, Ana diante dele. Passa uma lancha.

Adriane apontando para a prateleira de corpos.

Ana - Olha, Carlos, quero uma lancha grande como aquela ali!

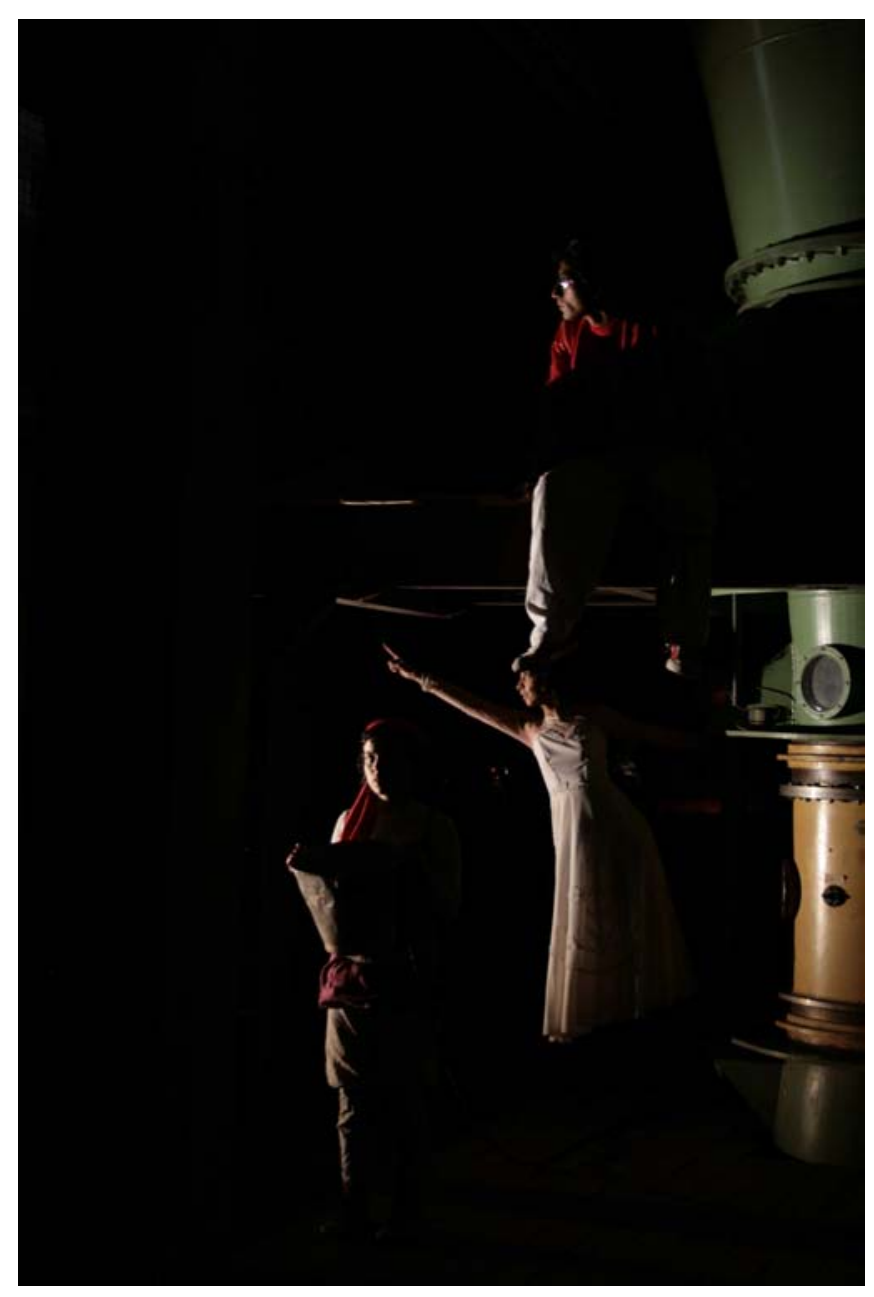

9. PRATELEIRA DE CORPOS: Katia e Anna. Daniel empurra prateleira e bate no elevador.

10. Larissa desce as escadas deitada, escorregando pelos degraus. Levantase e convida o público para subir as escadas. Algum celular toca. Júlio 
acompanha o público, dividindo-o em dois grupos, um que sobe as escadas e vê a cena seguinte de cima e outro que permanece atrás dele, vendo a cena de baixo.

\section{Felipe telefona para as pessoas:}

Alô, Fulano(a)? Posso te fazer uma pergunta?

Você é casado(a)?

Como você foi pedido em casamento? ou Você sonha em ser pedido em casamento? Como seria?

Hoje eu fui pedido em casamento, foi lindo! Foi em um jantar à luz de velas, com champanhe e tudo. Você acredita?

Só te liguei pra contar isso mesmo.

A estrutura acima é repetida duas vezes para diferentes telefonemas, sendo que a cada telefonema conta uma versão diferente do pedido de casamento. Essa estrutura serve de base para improvisar de acordo com a resposta dos espectadores. Há ainda um terceiro telefonema, dessa vez, para sua mãe, que não atende ao telefone de verdade.

Mãe, tudo bem?

Eu queria conversar com você e o papai, você reúne todo mundo no domingo lá em casa? Não, não é nada grave. É muito bom.

Júlio lê o verbete sobre CASAMENTO do dicionário HUAISS da Língua Portuguesa, conduzindo o público até encostá-lo no vidro de onde se avista a piscina amarela.

\section{CASAMENTO}

1. ato ou efeito de casar.

2. vínculo conjugal entre um homem e uma mulher.

3. união voluntária de um homem e uma mulher, nas condições sancionadas pelo direito, de modo que se estabeleça uma família legítima.

4. qualquer relação comparável à de marido e mulher.

5. o ritual que confere o status de casado, a cerimônia de casamento e suas festividades.

6. associação, aliança.

7. combinação harmoniosa de duas ou mais coisas; união estreita e íntima.

8. passa de figo com recheio de pedaços de noz. 
9. casamento branco: casamento sem relações sexuais.

10. casamento aberto: aquele que os cônjuges têm outros parceiros sexuais com mútuo consentimento.

12. PISCINA AMARELA: Daniel, Adriane e Paula. Música "Vuelva al Sur", de Astor Piazzolla. Cena vista em plano geral. Os atores retomam a ação da morte do dragão de "O Dragão da Maldade contra o Santo Guerreiro", com o mesmo efeito de repetição presente no filme. Também recuperam a cena em que o bandido tenta se matar bebendo tinta a óleo de "O Bandido da Luz Vermelha".

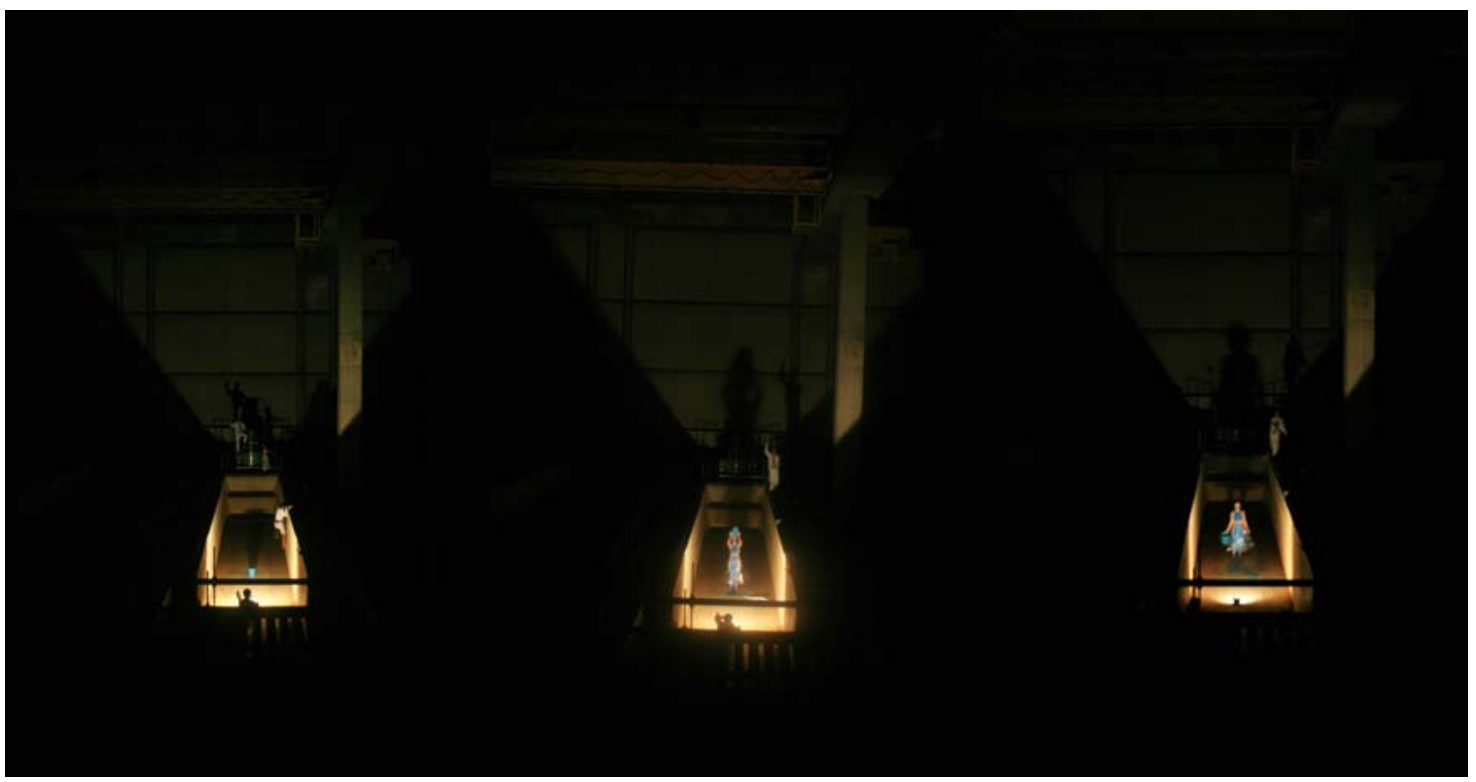

13. Felipe chama a atenção de dentro do corredor, local onde se encontra o público. Iniciando uma entrevista com o político J.B. da Silva (personagem do filme "O Bandido da Luz Vermelha"). Felipe faz o jornalista que entrevista o político Júlio.

J.B. da Silva, o candidato da Boca à Presidência da República. Por favor, senhores, me acompanhem.

Jornalista- Sr. J. B. da Silva, qual seu programa de governo?

Político - Eu sou praticamente um vitorioso. Foi preciso, senhores, foi preciso parecer um místico de terno branco e lenço encarnado no pescoço para dar ao povo uma luz de esperança. O programa do meu governo é eu mesmo! Eu!

Jornalista - Dizem que o ministro...

Político (interrompendo) - Ministro, não, secretário!

Jornalista - Exatamente, dizem que o secretário... 
Político (interrompendo novamente) - E tem mais uma coisa, jovem, eu vou abrir as portas das prisões, vou comprar vassoura piaçava, creolina e principalmente isso aqui (mostra bombinha de detefon). Vai ser a desinfecção dos cofres públicos.

Jornalista - A sua candidatura sai pelo seu partido?

Político - Exatamente, pelo glorioso Partido Trabalhista Cristão.

Jornalista - Mas, Excelência, não estamos em cima das eleições?

Político - Não há motivo para ter pressa. Sairá quando chegar a hora, porque o Brasil em vez de andar carangueja.

A dupla conduz o público até a próxima cena.

14. CABINE: Anna, Katia e Juliana na cabine. Referência a uma cena de "O Bandido da Luz Vermelha”. Políticos conduzem até a próxima parada do público.

\section{PLONGÉE: Daniel, Adriane, Paula e Clóvis.}

Texto de Alan Lightman, gravado pelas narradoras Anna e Katia:

... o corpo não é o resultado de uma mágica fantástica

mas uma coleção de elementos químicos, tecidos e impulsos nervosos. Pensamentos não são mais que oscilações elétricas no cérebro.

Excitação sexual não passa de um fluxo de elementos químicos para as extremidades de certos nervos. Tristeza nada mais é que um pouco de ácido transfixado no cerebelo. Em resumo, o corpo é uma máquina, sujeito às mesmas leis da eletricidade e da mecânica que um elétron ou um relógio. Portanto, ao falar do corpo deve-se usar a linguagem da física. E, se o corpo fala, é a fala de nada mais que um número de alavancas e forças. $O$ corpo não é uma coisa a que se obedece e sim uma coisa em que se manda.

16. Felipe continua a entrevista com o político Júlio.

Jornalista - J.B. da Silva o candidato da Boca à Presidência da República. Dizem que o ministro...

Político (interrompendo) - Ministro, não, secretário!

Jornalista - Exatamente, dizem que o secretário é um mestre no piano, um novo Mozart, Excelência?

Político - Compus chorinhos, valsinhas, coisa à toa...

Jornalista - Já matou alguém?

Político - Não, eu não, quem mata é Deus.

Jornalista - A que deve tanta sorte nos atentados, Excelência? 
Político - À Divina Providência, sem dúvida, e à fanática confiança em mim mesmo.

Continuam a condução do público por escadinhas, entre a plataforma II e III. Passam por Clóvis falando o seguinte texto (uma referência ao anão do "Bandido da Luz Vermelha):

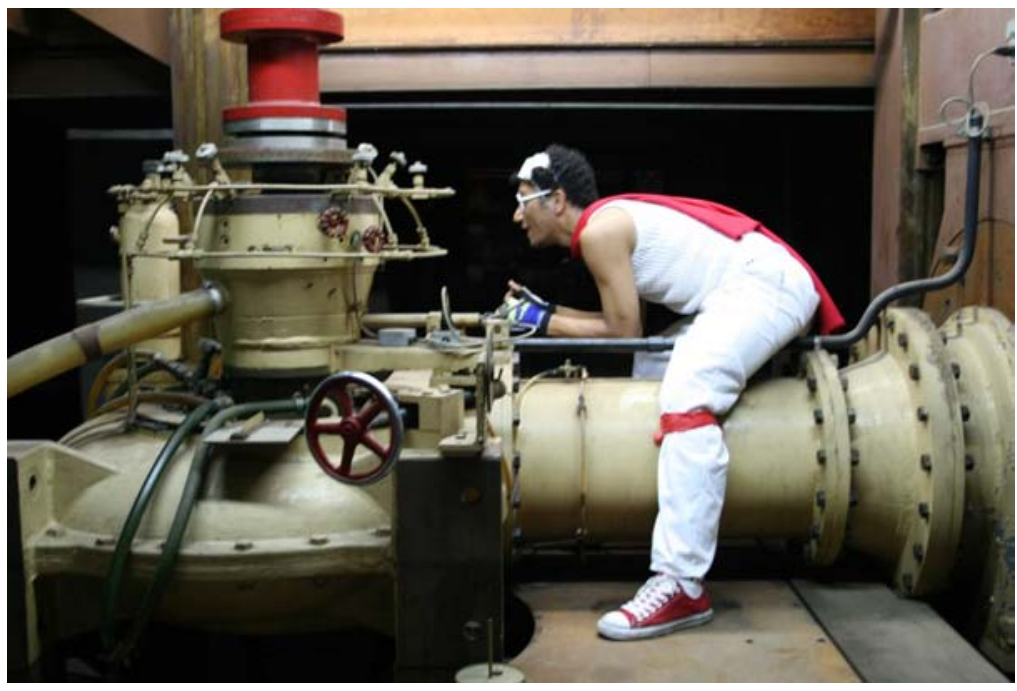

O terceiro mundo vai explodir, quem estiver de sapato não sobra. $A$ solução pro Brasil é o extermínio total. Eu sou poeta, eu vejo.

Enquanto o Político tenta dissuadir o público de prestar atenção no "anão", o jornalista repete duas vezes o texto a seguir, tempo necessário para a passagem do público até a próxima parada:

Jornalista - O tempo passa e o crime continua, senhoras e senhores. Além dos cinco delegados chefiando duzentos homens, cinco Wolkswagens "frios", equipados com rádios, sessenta radio patrulhas e setenta dedos duros por toda São Paulo. Contrataram algumas mulheres treinadas no tiro ao alvo e no Karatê para servirem de isca; cada uma recebeu um luxuoso carro para desfilar pelos pontos mais suspeitos, mas depois de quarenta e oito horas viram que não enganavam ninguém além dos ladrões de segunda classe... Eram manjadas demais na própria boca do crime. 


\section{CORO DAS MENINAS.}

Seis mulheres deitadas no chão desconstroem a música "Isaura", de Herivelto Martins. Clóvis marca o pulso em uma das máquinas.

18. Condução de Daniel pelo corredor.

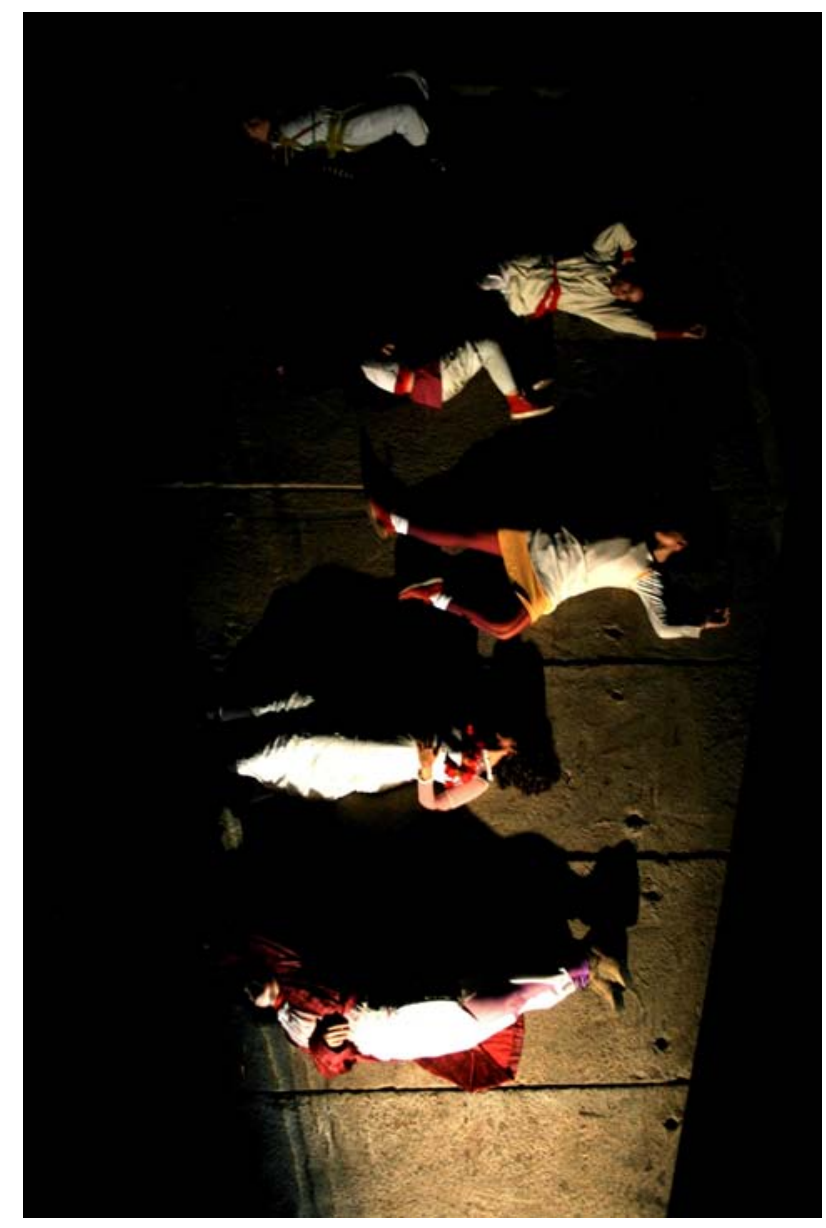

Pílula. Pílula. Pílula. Pílula. Pílula.

19. AVIADOR: Clóvis, imagem a ser observada em deslocamento. Condução do público para a plataforma I - Dani e Anna.

20. Anna recupera o seguinte texto:

Recomeçar, trabalhar, mil vezes tentar ser um homem. Recomeçar.

Anna canta Sabor a mi, música de Alvaro Carrillo, cantada por Roberto Luna no filme "O Bandido da Luz Vermelha".

Daniel e Adriane dançam na plataforma III, depois saem discutindo pelas escadas que levam à plataforma II.

Paula, na cabine, grita aleatoriamente:

Sim. Não. Não. Sim. Sim. Não. Sim.

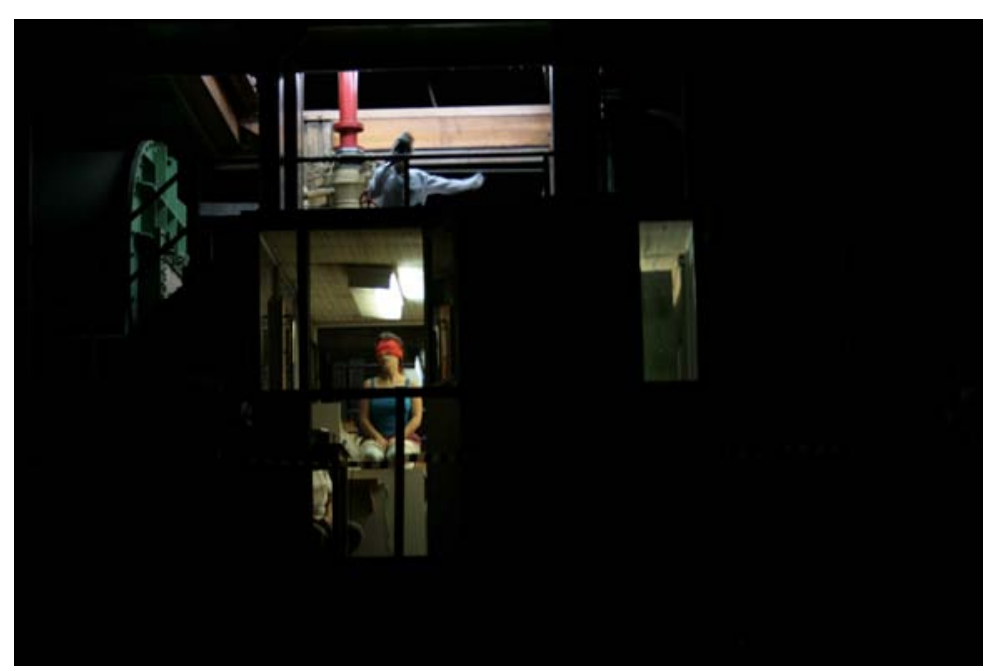




\section{Batidas de metal (Felipe)}

Katia com microfone diz texto dos radialistas de "O Bandido da Luz Vermelha":

Ninguém sabe quantos assaltos, roubos, incêndios e atentados ao todo ele já praticou. Ele pode atacar a qualquer hora do dia ou da noite, o bandido mascarado não respeita a mulher, nem a propriedade privada de ninguém.

Com 26 anos e 26 mortes ele foi condenado a 167anos, 8 meses e 2 dias de prisão; fora a multa de 10 cruzeiros novos.

Dentro de 48 horas no máximo o criminoso deverá estar preso, garante o investigador Saade, Cabeção para os íntimos. A $17^{\mathrm{a}}$ vítima do bandido não pode prestar declarações porque continua em estado de choque, porque afinal de contas também é gente.

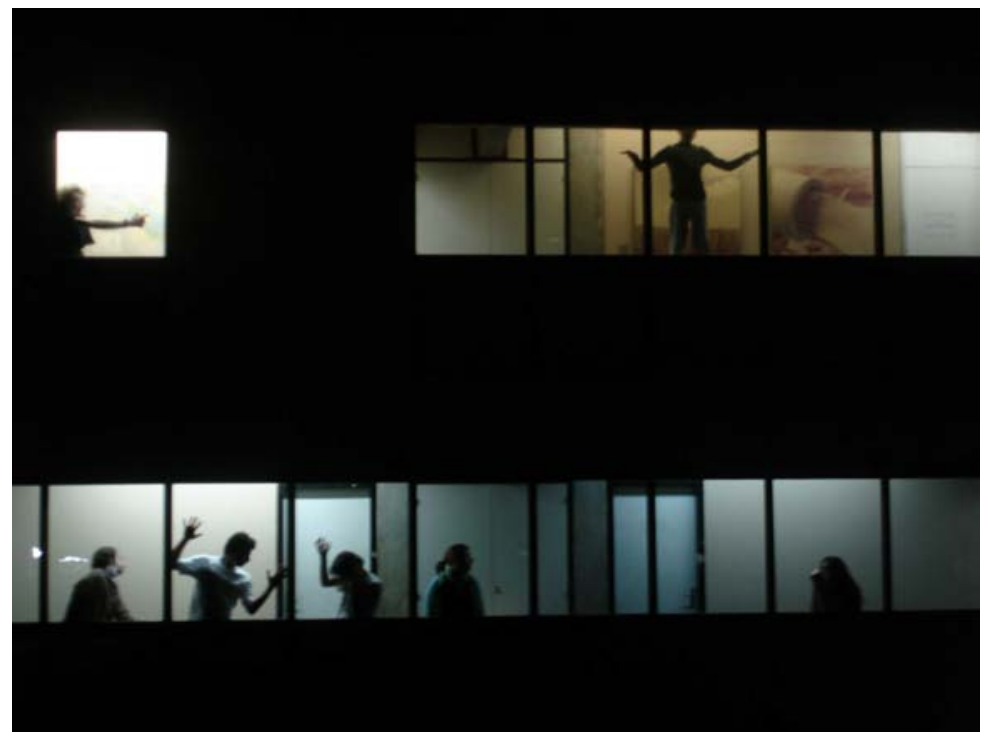

21. 3 x 4 nos corredores, mesmo ponto de vista da plataforma I.

\section{PICHAÇÃO do Clóvis.}

Woce pulicial do mal seu boçal woce naum me pegará nunca. Ass

23. CÁPSULA: Katia, Daniel e Clóvis na passarela. $O$ seguinte texto (Manifesto Futurista, de Marinetti) é ouvido gravado durante a cena:

Há vinte e sete anos, nós futuristas contestamos a afirmação de que a guerra é antiestética... Por isso, dizemos:... a guerra é bela, porque graças às máscaras de gás, aos megafones assustadores, aos lança-chamas e aos tanques, funda a supremacia do homem sobre a máquina subjugada. A guerra é bela, porque inaugura a metalização onírica do corpo humano. A guerra é bela, porque enriquece um prado florido com as orquídeas de fogo das metralhadoras. A guerra é bela, porque conjuga numa sinfonia os tiros de fuzil, os canhoneiros, as pausas entre duas batalhas, os perfumes e os odores de decomposição. A guerra é bela, porque cria novas arquiteturas, como a dos grandes tanques, dos esquadrões aéreos em formação geométrica, das espirais de fumaça pairando sobre aldeias incendiadas, e muitas outras... Poetas e artistas do futurismo... lembrai-vos desses princípios de uma estética da guerra, para que eles iluminem vossa luta por uma nova poesia e uma nova escultura!

\section{ANTIFESTA OU CAOS}

Público é convidado para um intervalo, que não acontece, é apenas o tempo dos atores chegarem aos seus próximos pontos. O público está fechado em um 
espaço pequeno, delimitado por fitas de segurança. Há uma mesa com jarros de água e copos.

Adriane e Katia na plataforma III. Referência à cena do carnaval de Hilda de São Paulo S/A. Jogam aviõezinhos de papel e estalos no público.

Paula e Daniel, na casinha, brincam com garrafinhas de água.

Juliana e Clóvis no foguete, ele na parte de baixo e ela na parte de cima.

Felipe de noiva costura a seqüência das ações de forma caótica. Todos os jogadores retomam momentos anteriores da peça; é um momento de síntese.

JOGO DE SOMBRAS realizado por Júlio e Larissa, referência à cena de "O

Dragão da Maldade contra o Santo Guerreiro". Gelatinas dispostas nos suportes dos slides colorem a cena com as cores do tecnicolor, tal qual as cenas do filme "Pierrot le Fou", de Jean-Luc Godard.

Condução de Adriane e Paula, com carrinho, passando pelos HOMENSPÁSAROS: Katia e Clóvis.

25. PANORÂMICA ISAURA - grupo todo. Exploram o texto de Ítalo Calvino extraído de "As Cidades Invisíveis".

Presume-se que Isaura, cidade dos mil poços, esteja situada em cima de um profundo lago subterrâneo. A cidade se estendeu exclusivamente até os lugares em que os habitantes conseguiram extrair água escavando na terra longos buracos verticais: o seu perímetro verdejante reproduz o das margens escuras do lago submerso, uma paisagem invisível condiciona a paisagem visível. Isaura, segundo alguns, vive nas profundidades, no lago negro que nutre as veias subterrâneas. Segundo outros, Isaura vive nos baldes que, erguidos pelas cordas, surge nos parapeitos dos poços, nas roldanas que giram, nas alavancas das bombas, nas pás dos moinhos de vento que puxam a água das escavações, nas torres de andaimes que sustentam a perfuração das sondas, nos reservatórios suspensos no alto dos edifícios, nos estreitos arcos dos aquedutos, em todas as colunas de água, tubos verticais, tranquetas, registros, até alcançar os cataventos acima dos andaimes de Isaura, cidade que se move para 0 alto.

26. Condução de Adriane, Paula e Anna, que diz.

Carlos, o que era esse lugar? 


\section{Dani fazendo XIXI.}

28. Juliana surgindo de dentro de uma das máquinas fala o texto abaixo, atrás de Felipe e Júlio que formam uma imagem de baralho: os dois políticos espelhados.

Jornalista: J. B. da Silva, o Rei da Boca e da Corrupção Paulistana.

J.B. da Silva, o Rei de Boca e da Corrupção Paulistana, utiliza suas imunidades parlamentares para fugir a sete processos, inclusive sendo acusado de co-provocador de incêndio de um cartório de registro de imóveis e principal responsável pelo contrabando de mais de meio milhão de latas de sardinha podres.

Políticos: Não, sardinha não. Não, sardinha não. Tilápia. Tilápia

Jornalista: Há quarenta e cinco anos, no dia de sua primeira comunhão, J. B. jurava que seria Presidente da República para tirar o povo da miséria ou então no mínimo deputado. Mas só conseguiu se eleger vereador em 1936, quando obteve a expressiva votação porque, durante a revolução de trinta e dois foi espião dos paulistas no Rio. Essa é a verdadeira história do homem que bebia uma garrafa de uísque estrangeiro por dia; do inventor da revolucionária jogada aberta do bicho; do chefe supremo, rei e talvez a própria lei de um império de um milhão de metros quadrados: A Boca do Lixo, onde, segundo ele: "Não existem habitantes, apenas sobreviventes".

29. Conduzido pelo Cão, público ouve o seguinte texto vindo dos subterrâneos da Hidráulica, o texto foi gravado por todo o Coletivo:

A cidade subterrânea, com suas cavernas e galerias, onde no filme moravam milhares de trabalhadores, já desapareceu: dinamitada. Muralhas, castelos, fortificações, registros, trincheiras e fossas destruídas. Não se pode prever o fim, a lei da metamorfose é impenetrável. O que acontece com os objetos depois de adquirirem o brilho do gesso? São jogados fora.

A água não é tão profunda como aparece na imagem, mas os elevadores em chamas que explodiram são em tamanho natural. Os objetos estão aqui apenas para o que devem representar no momento. Não pertencem à realidade; desconhecem um desenvolvimento no tempo. 
30. Aquário, onde Larissa realiza a ação inicial de forma desconstruída.

Anna escreve texto no vidro:

Foi assim que eu ensaiei pra morrer.

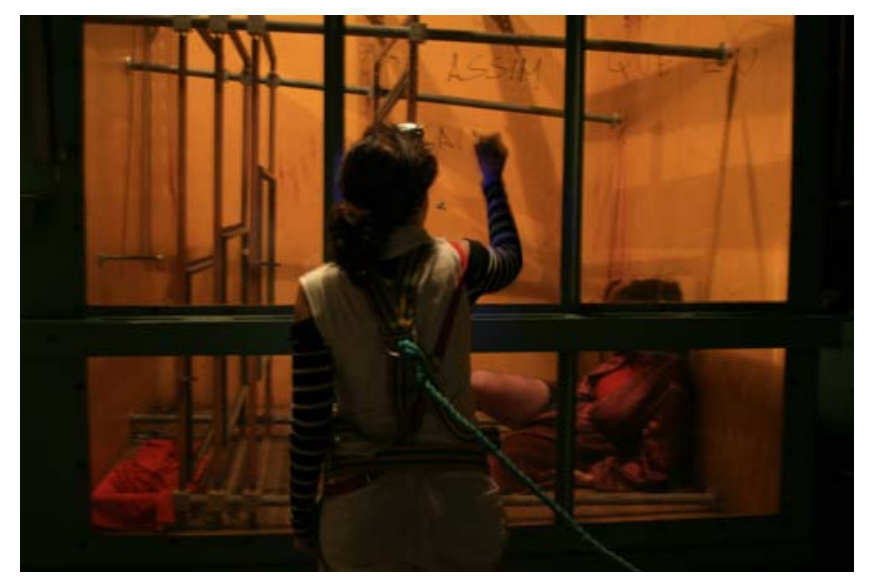


Imagem de Katia jogada sobre a barra de ferro da piscina de musgo. Em sua capa de chuva, lê-se:Foi assim ...

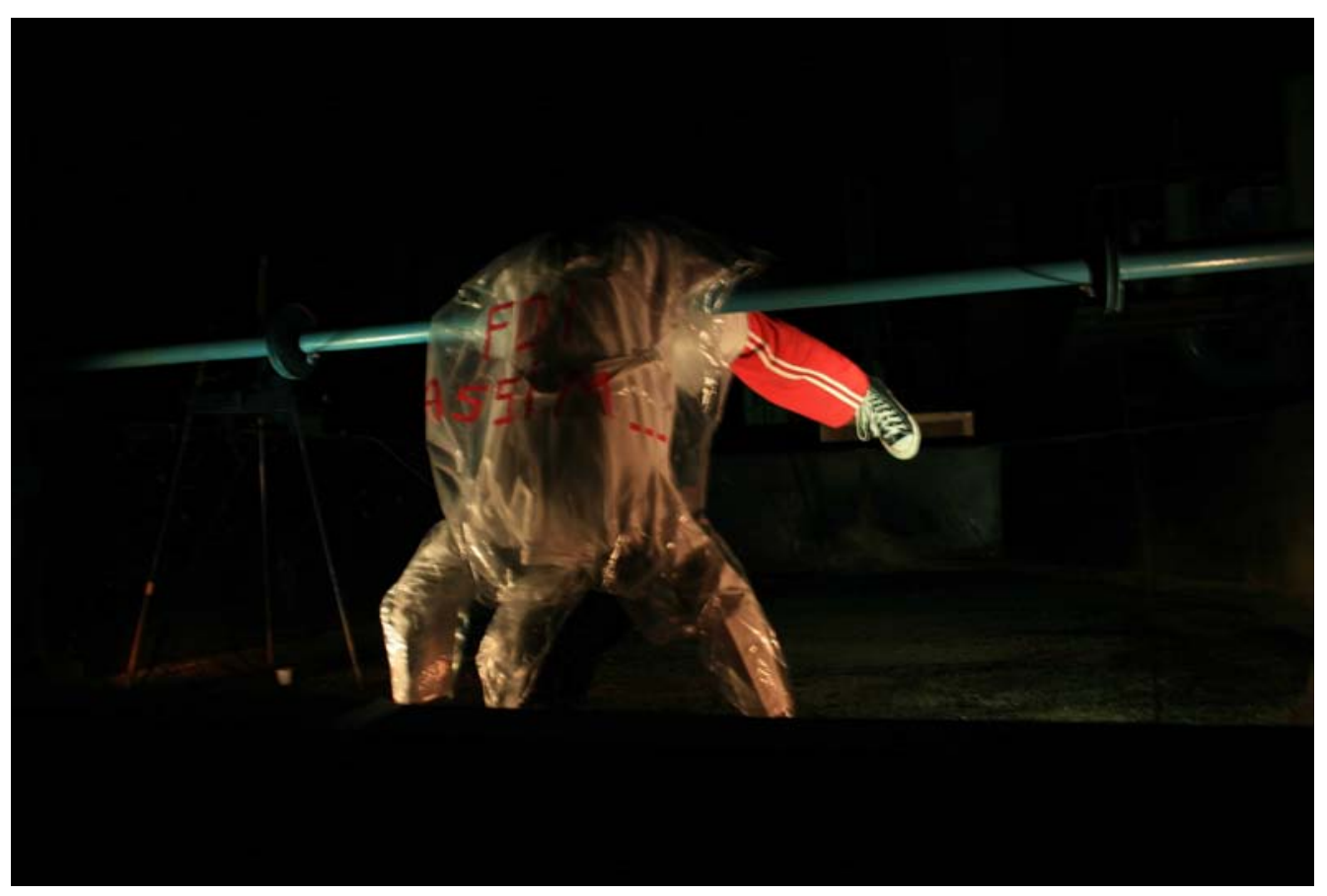

31. Mesmo portão do início. A música tema é "tocada" nos tubos de ventilação, juntamente com a voz de Adriane entoando a canção. Paralelamente, apresenta-se a cena da morte do cangaceiro: Felipe (de noiva) mata Daniel, que diz:

Foi assim que eu ensaiei...

32. Caminhada Final, retomando mesma imagem do início, o público observa a linha de atores de costas saindo em silêncio. Um fusca chega e recupera os atores. Esse final foi improvisado de maneiras diferentes a cada apresentação: algumas vezes os jogadores empurravam o fusca; em outras, alguns deles entravam no fusca; e ainda houve uma ocasião em que o fusca saiu da Hidráulica e o portão foi fechado. Ao que os jogadores responderam subindo no portão:

O terceiro mundo vai explodir e quem estiver de sapato não sobra. 


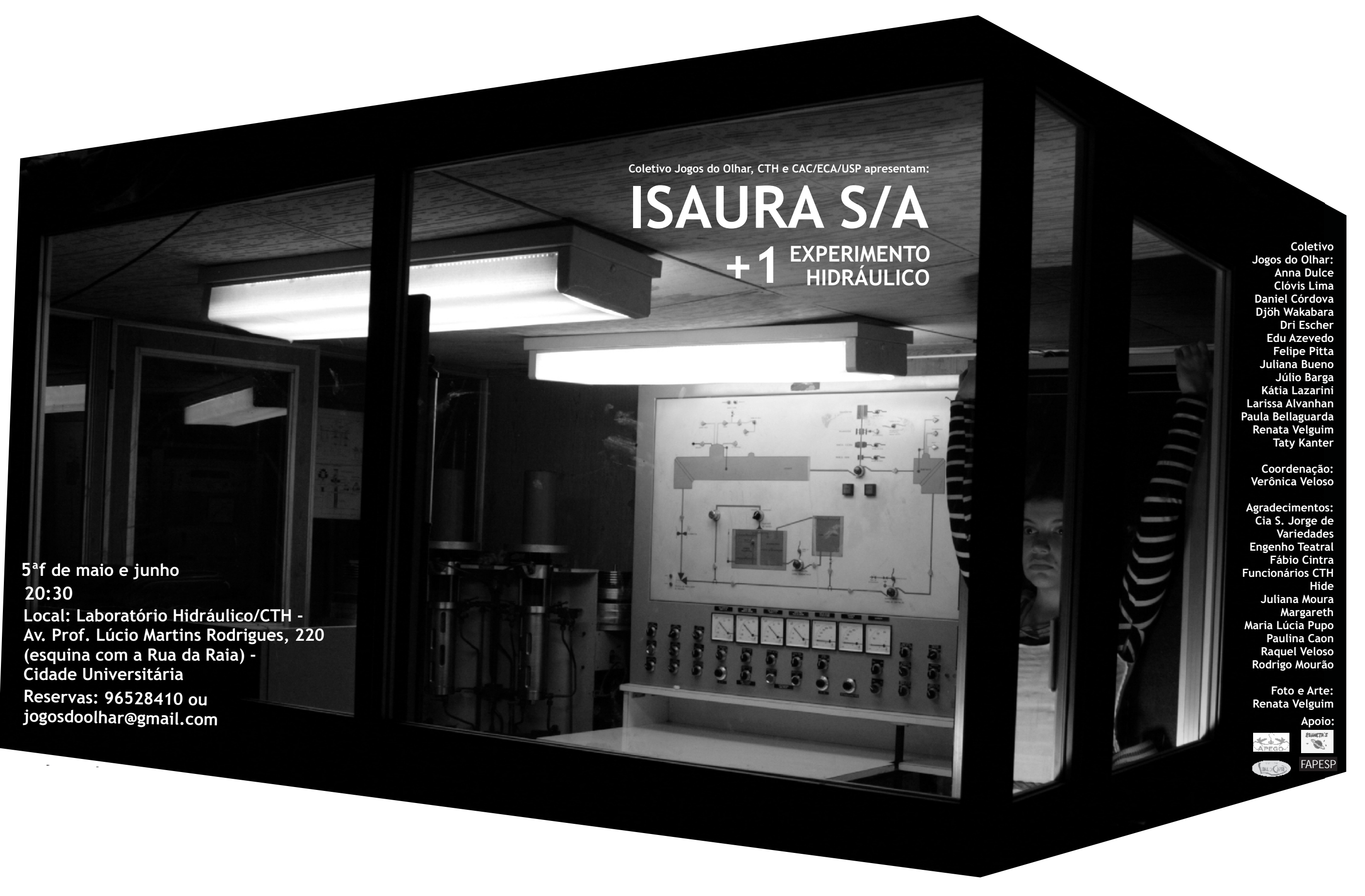




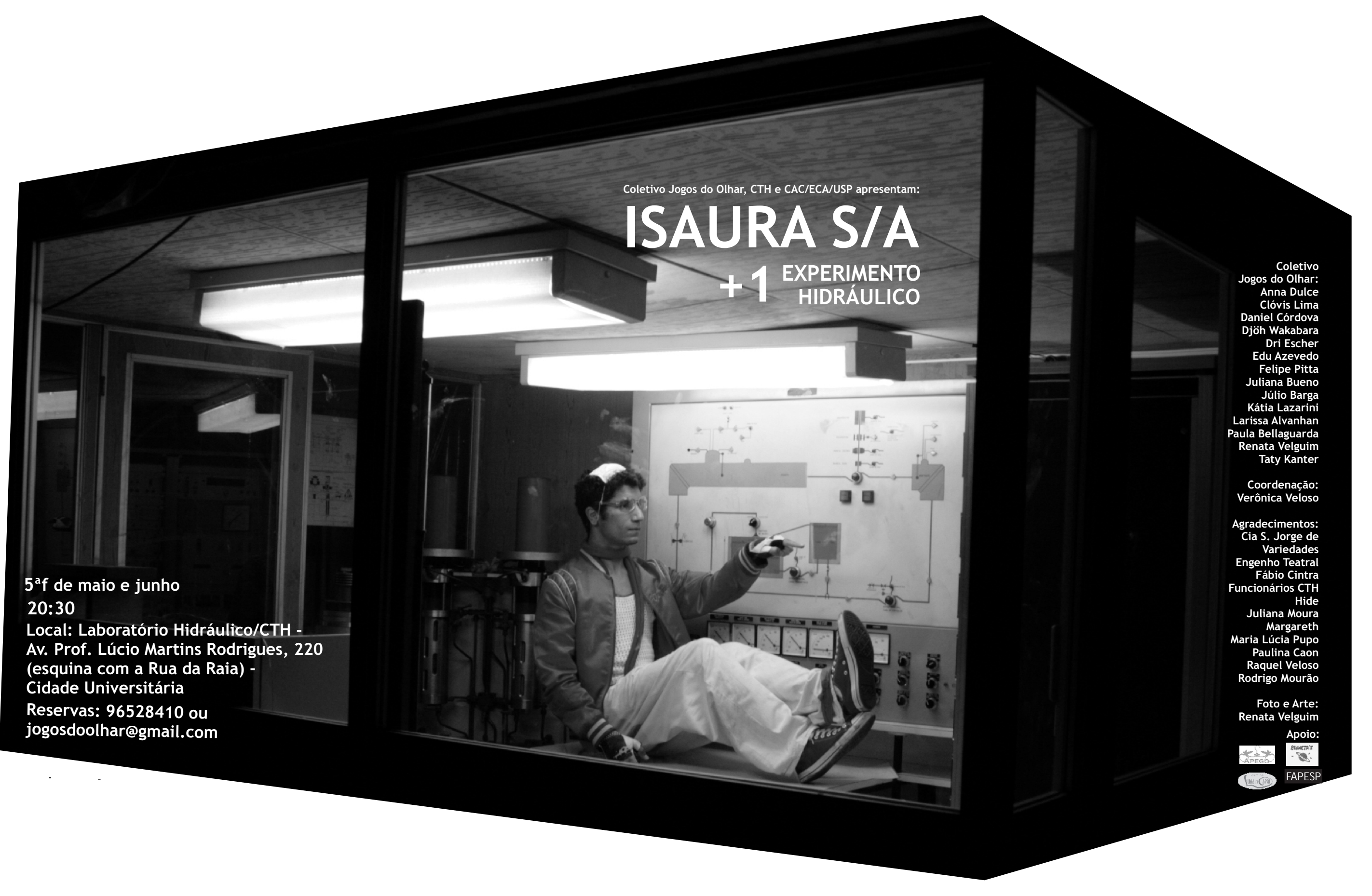




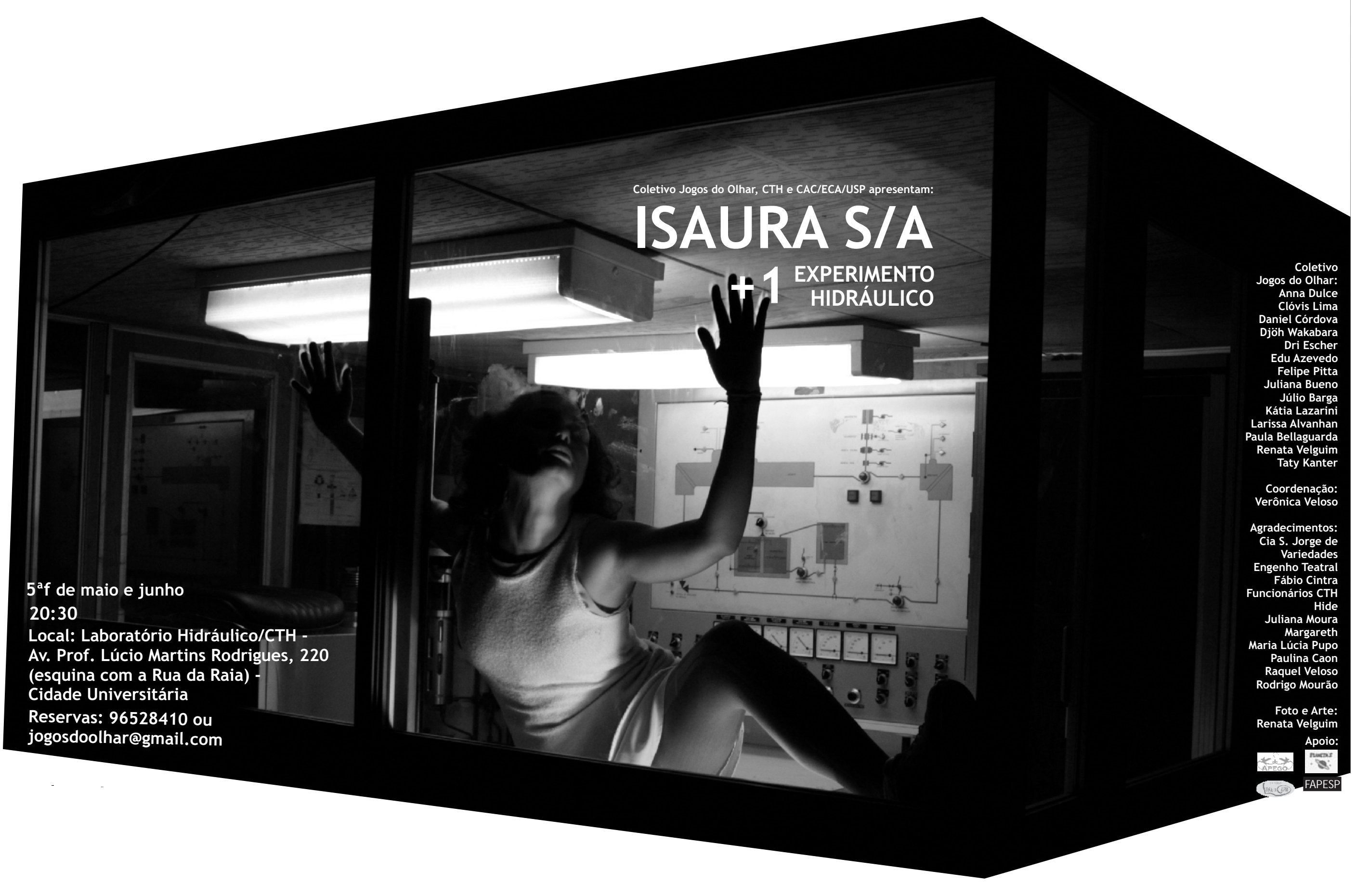




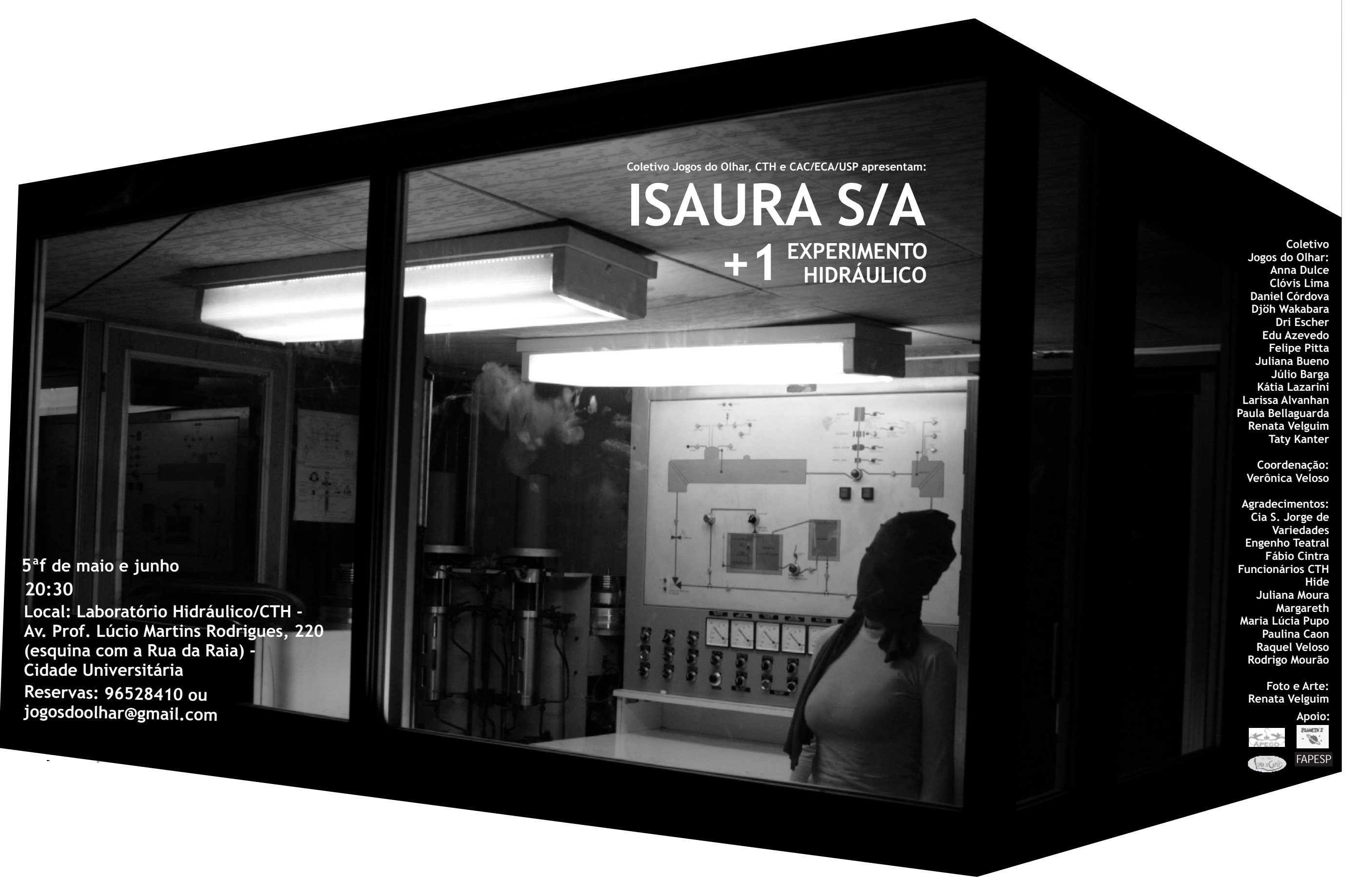




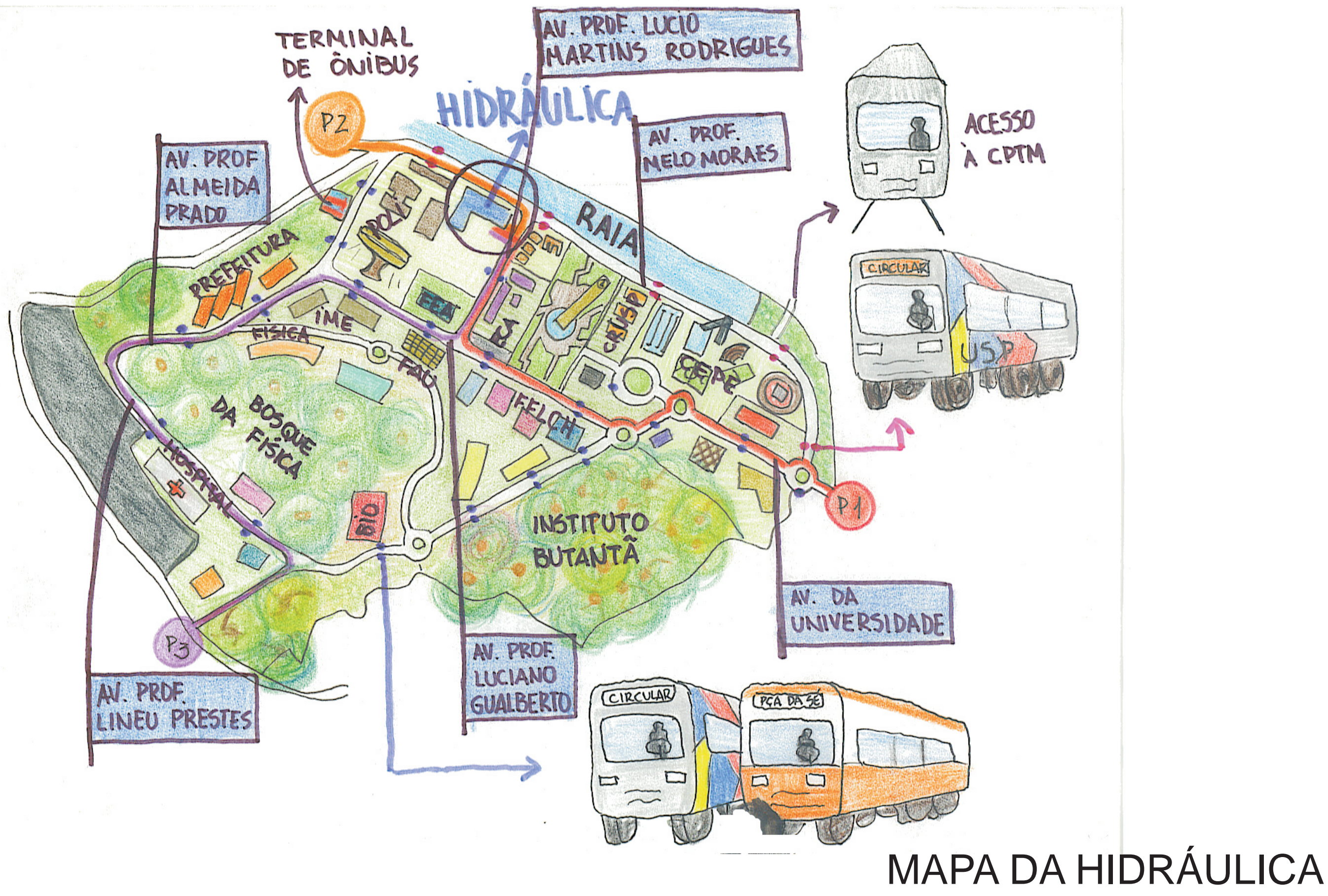




\section{Operações do Olhar}

"A filosofia pretende igualar o ver e o saber, tomar posse intelectual da visão, dizendo o que é ver e quem somos nós que vemos, como se nada soubéssemos do ver e de nós quando vemos"

Marilena Chauí

Neste estudo experimentamos a criação de uma encenação teatral a partir da observação de certos procedimentos oriundos do cinema. Aliamos teoria e prática na escrita da encenação e da presente dissertação, esperando que uma experiência pudesse nutrir a outra. Do mesmo modo, observamos operações próprias à linguagem cinematográfica e ensaiamos sua transposição para o teatro. A experimentação prática desse estudo contou com a colaboração de um coletivo de artistas que se dedicaram e se envolveram em um processo de ensino e aprendizagem em que essas funções se confundiam. Nesse mesmo sentido, a criação estava imbricada na educação e vice-versa, sendo impossível dissociar o momento da criação do momento da aprendizagem. Cada movimento da pesquisa, da leitura inicial de cenas de cinema à transposição da linguagem, da escolha da locação à seleção de ações físicas nos filmes, da sobreposição de textos à recepção do público, definiu as operações do teatro que se fez. A presente pesquisa resultou também em uma Coleção de Jogos do Olhar - um conjunto de jogos selecionados a partir de um olhar que se voltou para outra linguagem encarregada de construir o visível.

Todas essas operações do olhar possibilitaram, portanto a criação de uma encenação, de uma coleção de jogos e do presente texto. Tecer as considerações finais dessa pesquisa engloba instâncias distintas e, ao mesmo tempo, intimamente relacionadas. Desse modo, partiremos do ponto de vista de Roland Barthes sobre o olhar, esperando que o modo metafórico colabore com a elaboração de uma reflexão cujos temas estão entrelaçados.

A ciência interpreta o olhar de três maneiras (combináveis): em termos de informação (o olhar informa), em termos de relação (os olhares se cruzam), em termos de posse (pelo olhar, toca, alcanço, capto e sou captado): três funções: ótica, lingüística, de captação. $O$ olhar, porém, sempre procura: alguém, alguma coisa. É um signo 
inquieto: singular dinâmica para um signo: sua força o ultrapassa.

(BARTHES, 1990, p.277-278)

Em termos de informação, podemos dizer que tomamos o cinema como objeto do olhar. A função óptica é receptora, acolhe a outra linguagem (o cinema), o diferente e o observa. Em termos de lingüística, podemos discutir os cruzamentos de funções dentro do coletivo, atentando-nos à leitura das relações estabelecidas entre os participantes desse agrupamento. Já em termos de captação, referimo-nos às situações de ensino-aprendizagem mescladas à criação da encenação. Através da educação, o sujeito se apropria de conhecimentos e valores que o acompanham na construção de seu teatro que, observado a partir de uma escala maior, pode ser entendido como seu mundo. A perspectiva explicitada na frase anterior pode ser lida como um convite para ajustes da lente sobreposta ao olhar. Em alguns momentos olharemos de perto para questões particulares, relativas às operações específicas do Coletivo; em outros, abriremos a lente para ver através de uma grande angular, levando-nos a reflexões sobre o teatro recente, suas relações com o cinema e as novas tecnologias. Abrindo e fechando as lentes, a citação de Barthes nos acompanhará até o final dessas considerações, não finais, mas momentâneas, possíveis por hora.

Assim sendo, nosso olhar procurou no cinema informações que pudessem colaborar com os impasses observados na cena teatral contemporânea. A função óptica do olhar nos ajudou a identificar em alguns procedimentos cinematográficos saídas para a cena teatral que se instala em uma locação não oficialmente teatral. Alguns artistas julgam a saída do palco à italiana uma libertação do enquadramento ao qual a cena estava necessariamente subjugada. Apesar de em algumas cenas aproveitarmos a ausência de demarcação do espaço, própria desse teatro fora da sala oficial, optamos justamente pelo contrário. Ao revelar enquadramentos latentes na arquitetura, vistos sob determinado ponto de vista, apontamos uma saída para a ressignificação do theatron contemporâneo. Ou seja, ao invés de deixar o olhar do espectador disperso, optamos por indicar focos de interesse, destacar recortes, construir junto com o público um ponto de onde se avista. Sob esse aspecto a escolha foi pontual, embora tenhamos considerado eventualmente a explosão do espaço, abrindo completamente o foco do espectador para a 
observação. No nosso caso, portanto, a saída do palco tradicional é oportuna para a criação de um teatro que propõe jogos para o olhar, ou seja, operações construídas a partir do posicionamento do observador diante de certo espaço enquadrado. Assim, não só o olhar é dotado de movimento, mas o corpo todo do espectador é conduzido pelo seu olhar. Há um esforço, uma demanda por querer ver, uma busca inevitável do espectador pela obra de arte.

\footnotetext{
Só que a rigor, não existe este olhar absolutamente espontâneo, isento de premissas e expectativas, e relacionando-se direta e imediatamente com a obra. Este suposto olhar é na verdade, moldado pelas convenções habituais e pelas perspectivas dominantes (tão habituais e dominantes que parecem naturais, não construídas). (MATERNO, 2003, p.37)
}

Aquilo que chamamos de dimensão lingüística do olhar se refere à leitura dos signos da cena, o que possibilitaria a perda da ingenuidade diante da linguagem audiovisual. $O$ ato de olhar conjuga teoria e prática, uma vez que na filosofia, ele é associado ao saber. A partir do momento em que o olho consegue discernir determinadas operações, efetiva-se o conhecimento. Desse modo, a leitura da cena cinematográfica pode ser encarada como uma ferramenta de leitura do mundo, uma vez que os códigos de comunicação e manipulação que transformam o sujeito em cliente, quiçá em mercadoria, estão associados à televisão, que por sua vez é derivada da linguagem cinematográfica. A pesquisadora Tamara Ka refere-se à televisão como uma lareira eletrônica, onde se aprende por osmose a ler e compreender uma convenção de escrita audiovisual como se fosse a única. O padrão proposto pelo discurso televisivo, no entanto, não pode ser rompido sem a sensibilização do olhar, de modo que o novo olhar que se volta para a televisão consegue enxergar os meandros dessa operação.

"Seria ingênuo perguntar: não deveríamos nos aproximar e apropriar das novas tecnologias com os olhos e ouvidos mirados na educação dos sentidos?" (TRAGTENBERG, 2006 apud KA, Tamara, 2008, p. 49) 42. Desse modo, relacionar-se com o cinema para se fazer teatro é também uma forma de lançar mão de um alfabeto familiar à maioria das pessoas, mesmo que

${ }^{42}$ TRAGTENBERG, Lívio. A atrofia virtual dos sentidos. Caderno Mais, Folha de São Paulo, 6/4/2006. 
inconscientemente. Diante da proliferação de informação audiovisual presente no cotidiano das grandes cidades, como abordado no capítulo 1, recorrer à linguagem cinematográfica parece não só interessante como inevitável, tanto para subverter sua recepção, quanto para utilizá-la como estímulo para as construções do visível.

Ainda no que se refere à lingüística, podemos nos ater às relações provenientes do olhar, "os olhares que se cruzam". Tal função nos remete às trocas estabelecidas no âmbito do Coletivo - Jogos do Olhar, decorrentes da opção pelos modos de trabalho adotados. Ao convidar toda e qualquer pessoa acima de 17 anos para integrar o Coletivo - Jogos do Olhar e ao longo de um ano e meio de convivência, definiu-se um tipo de organização colaborativa do processo criativo. Ou seja, a criação da encenação ocorreu de forma que os artistas assumissem funções específicas, sem que, no entanto, elas tivessem sido alternadas. Tal característica parece-nos relevante, pois esse tipo de processo favorece aos participantes uma espécie de familiaridade com todas as etapas da criação.

O que se nota, nesse caso, é que a participação ativa de atores, dramaturgo e diretor na concepção do texto e do espetáculo não impede que os envolvidos construam dramaturgias específicas da atuação, da palavra e da encenação, que às vezes podem não estar em completa sintonia. (FERNANDES, 2002, p. 38)

O caráter colaborativo da criação pede que, no momento de fechamento do ciclo, a coordenação (tarefa que me foi atribuída, tendo em vista a encenação) deveria tomar decisões, amarrando ou embaralhando os fios abertos durante o processo criativo. Diferente de uma criação coletiva, em que os papéis não são definidos e todos decidem coletivamente, no nosso caso, sente-se o peso de uma mão encenadora. No balanço final do experimento, lidamos com percepções diversas dos diferentes momentos do processo: ensaios, correções, melhoramentos e arrependimentos da encenação.

Segundo Patrice Pavis, "a análise do espetáculo é, nesse sentido, também uma psicanálise que diz tanto sobre nós como sobre o objeto percebido" (PAVIS, 2005, p.125). O olhar lingüístico aproxima-se desse tipo de análise do espetáculo, pois estabelece relações entre produto e processo, entre objetividade e subjetividade, entre artista e obra. Ele permite inclusive 
que o processo de criação seja revelado a partir da observação do "produto final". Diante de "ISAURA S/A", uma obra polifônica, resultante da mistura e da sobreposição de muitas vozes, fui questionada por um amigo sobre minha função. Ele me perguntava se eu não sentia falta de me entregar mais ao ato artístico, associando assim aquilo que ele considerava como entrega, ao exercício do ator. Ao contrário de sua impressão, colocando-me como artista, encenadora de uma obra, sinto-me mais entregue e exposta do que qualquer papel que eu tenha desempenhado como atriz ou performer. Secretamente, a encenação fala de intimidades que não ousaríamos colocar em cena se não fosse por meio de certo empréstimo por parte dos atores (empréstimo de corpovoz, de respiração, sentimento, reflexão e muito suor).

Analisando o processo revelado no objeto artístico, parece-me conveniente examinar algumas insatisfações dos jogadores, manifestadas no final do processo criativo. Tal análise, comparada por Pavis à psicanálise, refere-se à opção pelos modos de trabalho e a qualidade de entrega dos participantes (encenadora incluída) às funções pré-estabelecidas. Essa insatisfação não pode ser minimizada, mesmo que as angústias sejam parte constitutiva dos processos de criação artística. Muitas vezes tememos as crises e os descontentamentos com o processo de criação, entretanto as crises são provações que servem para sedimentar os processos e os descontentamentos movem os artistas, levando-os a buscar outras saídas, outras respostas. O encenador-professor deve observá-las com cuidado, buscando pistas para identificar ao longo do processo de criação e aprendizagem suas origens e suas conseqüências.

A questão que consigo formular se refere aos princípios iniciais dos Jogos do Olhar, como o próprio nome diz. Esses jogos se voltaram para a formação de uma visão do todo da obra de arte, visão geralmente associada à função do encenador. Pergunto-me se, depois de provar o gosto desse olhar que contempla a totalidade da encenação, todos os envolvidos ficaram satisfeitos na posição de jogadores. No cotejamento entre o fazer e o ver, será que ao compartilhar com os jogadores a função de encenadora encarregada do ato de ver, não os atraí também para essa atividade? Talvez o imprevisto desse percurso seja o potencial dos Jogos do Olhar de disponibilizar ferramentas para 
futuros encenadores-professores, o que não exclui a formação de atorescompositores conscientes de todas as etapas da criação teatral.

$$
\text { (protocolo de Anna Dulce) }
$$

"Aprendi exercícios que trabalham a cena de forma mais contemporânea e comecei a compreender a capacidade do próprio intérprete de compor plasticamente a cena."

Constatamos que o movimento proposto pelos jogos do olhar no sentido de convidar os jogadores para se colocarem também como espectadores, aproximou-os da função do encenador. Em um dos primeiros jogos, eu propunha que os jogadores definissem a posição do público em relação a um enquadramento. Guénoun afirma que o ofício do encenador é contemporâneo da invenção do cinema e que pode ter sua origem derivada da posição do espectador (GUÉNOUN, 2004, p. 118-119). Ao longo do processo criativo, todos os jogadores estiveram presentes como agentes da criação, da composição dos "fotogramas" (imagens estáticas) até a seleção de ações físicas para serem executadas na cena. Nesse momento, pode-se dizer que eles tenham praticado um tipo de antropofagia à moda oswaldiana. Quando passamos à fase da montagem, da articulação dos fotogramas, o que definiria uma sintaxe, um movimento próximo à configuração de um pensamento, o responsável seria aquele que está de fora. Quem edita ou quem monta o filme (nesse caso, peça), são aqueles excluídos pela imagem: o encenador e a equipe técnica. Assim sendo, será que as insatisfações dos jogadores no final do processo, perto do momento da estréia, se referiam em parte à dificuldade de se contentar com a função de jogador, ou seja, a função daquele que faz e não daquele que vê?

Para além das insatisfações, gostaria de me ater ainda sobre a etapa do processo anterior à fase da montagem, na qual os jogadores "fagocitavam" elementos dos filmes estudados. Nessa etapa, eles se colocavam diante dos filmes, imbuídos da função de seleção e pinçavam elementos que julgassem interessantes para a composição da encenação. Assim, como na escolha dos enquadramentos, os jogadores tiveram total liberdade de apropriar-se tanto de ações e procedimentos identificáveis no filme, como das cenas propriamente ditas. Entendemos, contudo, que nas ocorrências do primeiro caso o filme foi usado como modelo de ação, perspectiva prevista na nossa abordagem inicial 
do material cinematográfico. No segundo, todavia, o recurso fílmico foi utilizado de forma inesperada: a apropriação das cenas para serem reformuladas no ambiente da Hidráulica foi associada, posteriormente, à noção de estoque de imagens.

Ainda no que se refere às relações de ensino-aprendizagem, em contextos em que a criação e a educação estão entrelaçadas, percebo que muitas vezes a busca por um processo colaborativo, democrático, nãohierárquico, merece ser reconsiderada. Em poucas situações observamos 0 equilíbrio, a medida exata entre a colaboração e a tomada de decisões por parte do diretor. Nesses contextos, a impressão é de que o estatuto do encenador também está colocado em questão. $O$ tempo dos diretores carrascos parece ter ficado para trás, entretanto no império dos atores, "senhores" dos processos colaborativos, quais são as operações destinadas ao diretor? Que espaço ainda the resta? Do ponto de vista dos atores que se assumem como compositores conscientes de suas escolhas artísticas, a função do encenador precisa ser reinventada. Desse modo, a tarefa do encenador não parece simples, nem seu lugar parece garantido. Os primeiros Jogos do Olhar remetiam a uma encenação quase "compartilhada", o que me levou a assumir apenas em parte essa função, fato este que pode ter sido confundido com negligência. Diante desse impasse, como manter a autonomia dos artistas e a partilha das vozes entre atores e encenação?

Após vivenciar longas e numerosas conversas com o Coletivo, afirmando veementemente que a democracia no processo criativo demandava tempo, percebi que essas tentativas de valorizar a voz do coletivo nem sempre resultavam em maior autonomia por parte dos jogadores. Os aborrecimentos diante da morosidade de algumas conversas eram maiores do que as tomadas de iniciativa por parte deles. Da mesma forma, não acredito que a excessiva busca por uma criação democrática, às vezes confundida com desejo de agradar a todos, tenha resultado em real apropriação do processo criativo. Parece-me que a autonomia está mais associada ao tipo de demanda que o encenador propõe ao jogador, como por exemplo, delegando a ele a função de "colecionador". Imagino que o ator-criador de ISAURA S/A sentia que a cena, e por conseqüência a encenação, era "sua" quando revelava os espaços, as 
ações, as passagens e frases do filme selecionadas por ele, a partir de critérios pessoais, que diziam respeito à sua subjetividade.

Por hora, entendo que a conquista da autonomia passa pela manutenção das diferentes funções, pois quando todos os jogadores estiverem em cena, quem detém o ato de ver e tomar decisões é o encenador e ele não pode esperar o último momento para isso. Parece-me que os problemas do teatro não se resolvem com a democracia, talvez com um tanto de consenso, mas não democracia, pois eles vão além desse princípio, são da ordem da estética. Retornando à citação inicial, Roland Barthes associa o olhar à posse, confirmando a afirmação de que seria impossível separar o que vemos do que sabemos. Desse modo, a filosofia iguala o olhar, esse "signo inquieto", ao saber. Somente por uma pedagogia do olhar, aprendendo a enxergar os signos da composição do visível, pode-se captá-los, apropriar-se deles.

O olhar foi tomado como meio de apropriação de procedimentos de outra linguagem: o cinema. Aprender a ler a linguagem cinematográfica foi um modo de refletir sobre a escritura do visível, papel desempenhado por ambas as linguagens. Diante do contexto atual, além do ritual da sala de cinema, onde a experiência cinematográfica acontece plenamente, com a proliferação de novas tecnologias produtoras e reprodutoras de imagens, a necessidade e a função do teatro são postas em cheque. A teatralidade pós-cinema começou a ser definida e debatida paralelamente à crise do drama. No cenário teatral contemporâneo todos os estatutos estão sendo questionados: o texto, a sala tradicional, o personagem, a ficção, a representação. É um sinal de muitas mudanças e de grande produtividade. De acordo com Denis Guénoun, nunca se foi tão pouco ao teatro e, ao mesmo tempo, nunca tantas pessoas quiseram fazer teatro.

Portanto, a observação da linguagem cinematográfica norteou nossas escolhas no sentido de nos afastarmos de uma construção do visível própria do cinema, ou antes, de uma construção que seria mais bem sucedida se realizada nessa linguagem. No que se refere à impressão de realidade, a concorrência entre o teatro e o cinema é desleal, convidando o primeiro a voltar-se para suas especificidades, a teatralizar-se cada vez mais. Curiosamente, encontramos justamente no cinema, meios para munir o teatro de artifícios que o afastam dessa técnica de reprodução do real. Também 216 
encontraríamos ferramentas suficientes na sétima arte, caso estivéssemos interessados em buscar no cinema um manancial para criar impressões de realidade. Portanto, o que está em jogo é a observação da operação cinematográfica. É o modo pelo qual o estudo das partes desse "brinquedo quebrado" pode ativar a criação de um teatro que compõe com os elementos do mundo, provocando estranhamento e choque. Esse teatro convida o espectador a vivenciar uma experiência audiovisual fabricada por uma engenhoca lúdica, focada no potencial de brincadeira, de jogo, de fantasia, que não pode ser vivida na sala de cinema.

(protocolo de Adriane Escher)

"Pensar no ponto de vista já era uma questão e agora isso 'salta' mais ainda aos olhos, como os detalhes, pensar os recortes. Agora, mudou meu modo de ver cinema."

O resultado final dessa pesquisa, no que se refere à prática estava mais próximo de uma amostra do desencontro, do desencaixe, do desmonte. ISAURA S/A + 1 Experimento Hidráulico constitui, portanto, uma encenação metalingüística que exibe as condições de uma cena, cujo personagem principal, Isaura, não aparece. Não é revelado, até mesmo porque não existe, não sabemos onde está, nem quem é. Não é um segredo, não há enigma. Um teatro cujo assunto principal talvez fosse o espírito do nosso tempo. Um tempo no qual se caminha para a simbiose entre o corpo e a máquina. Depois da era Moderna, na qual passamos rapidamente da mecanização à micro-informática, para onde vamos? Qual o espaço do homem nesse contexto? Será que as escolhas de seus modos de vida não são ensaios para sua morte?

Todas as tentativas de tentar traduzir em meia dúzia de frases os sentidos impregnados naquelas imagens serviriam apenas para empobrecê-las, reduzindo-as a reflexões ingênuas e superficiais. Um teatro sem estória, sem sentido, organizado por uma sociedade anônima, proprietária de recursos precários, escassos. Uma "descomposição". Um teatro instalado em um local de experimentos, que se coloca como mais um, pois outros poderiam acontecer ou ter acontecido. Assim como cada modelo físico reduzido foi um mestrado ou doutorado de algum estudante da Escola Politécnica, ISAURA S/A foi mais um experimento que acompanhou e justificou um mestrado. Talvez no futuro, esse modelo teatral reduzido possa servir para outros pesquisadores, 
talvez ele possa terminar na estante da biblioteca até que os computadores cheguem e todas as dissertações sejam incineradas ou levadas até um cemitério acadêmico (como aconteceu com os modelos da Hidráulica a partir de outubro de 2008).

Parece relevante, portanto, lançar outras idéias para o futuro, considerando o olhar como esse "signo inquieto", sempre à procura. Assim como a Hidráulica era um espaço que representava o futuro de um passado, precisamos apontar amorosamente para o futuro. As operações do olhar aqui apresentadas poderão receber desdobramentos e versões que venham a promover o intercâmbio entre as escritas do visível. Eisenstein falava, na década de 1920, em um cinema em relevo, perante suas insatisfações com a tela bidimensional. Peter Greenaway, por sua vez, afirma que o cinema ainda hoje está na pré-história, pois se restringe à ilustração do texto. Sem querer ousar a certeza de um oráculo, mas exercitando o lançamento de idéias para o futuro, imagino que outras pontes entre teatro e cinema ainda serão edificadas, com o pretexto de organizar e sublimar imaginários sobrecarregados. Dirijo-me, contudo aos que encaram a prática da imagem "efetivamente [como] uma práxis, um campo de operações reais" (GUÉNOUN, 2004, p. 128). E espero que estes experimentem vigorosamente novas configurações para as teatralidades pós-cinema. 


\section{Bibliografia}

ARGAN, Giulio Carlo. Arte Moderna. São Paulo: Cia. das Letras, 1992.

ARTAUD, Antonin. Linguagem e Vida. São Paulo: Editora Perspectiva, 1995.

. O Teatro e seu duplo. São Paulo: Martins Fontes, 1993.

ARRUDA, José Jobson de A. História Moderna e Contemporânea. São

Paulo: Ática, 1975.

ALBERA, François. Eisenstein e o construtivismo russo. São Paulo: Cosac

\& Naify, 2002.

AUMONT, Jacques. O Olho Interminável (cinema e pintura). São Paulo:

Cosac \& Naify, 2004.

Le cinema et la mise en scène. Paris: Armand Colin, 2006.

AUTANT-MATHIEU, Marie-Christine. Le Cosmos Kolej: voyage au grenier de l'imaginaire (avec une escale au pays d'"Ulysse à l'envers"). In : PICON-

VALLIN, Béatrice (org.). La scène et les images. Paris, CNRS Éditions, 2004, p. 320-340.

BACHELARD, Gaston. A Poética do Espaço. São Paulo: Martins Fontes, 1996.

BARROS, Manoel de. Arranjos para Assobio. Rio de Janeiro: Ed. Record, 1980.

BARTHES, Roland. A câmara clara. Rio de Janeiro: Nova Fronteira, 1984. . Fragmentos de um discurso amoroso. São Paulo: Martins Fontes, 2003.

Introduction à l'analyse structurale des récits. In BARTHES et al, L'analyse struturale du récit. Paris: Éditions du Seuil, 1981, p.7-33. O Óbvio e o Obtuso. Ensaios Críticos III. Rio de Janeiro: Nova Fronteira, 1990.

BAUMAN, Zygmunt. Modernidade Líquida. São Paulo: Jorge Zahar, 2001.

BAZIN, André. Qu'est-ce que c'est le cinéma? Paris: Les Éditions du Cerf, 2002.

BENJAMIN, Walter. Magia e Técnica, Arte e Política: ensaios sobre literatura e história da cultura. (Obras escolhidas, vol. 1). 7 ed. São Paulo:

Brasiliense, 1994.

BERNARDET, Jean-Claude. 0 que é cinema. 11 ed. São Paulo: Brasiliense, 1991.

São Paulo Sociedade Anônima. O filme de Luís Sérgio Person descrito por Jean-Claude Bernadet. Rio de Janeiro: Alhambra e Embrafilme, 1987.

BERSTEIN, Ana. A casa com vista para o mar de Marina Abramovic. Sala Preta. Revista de Artes Cênicas (ECA/USP), São Paulo, n.3, p. 132 140, 2003.

BOGART, Anne. A Director prepares seven essays on Art and Theatre. New York: Routledge, 2001.

BOGART, Anne; LANDAU, Tina. The Viewpoints Book. A Practical Guide to 
Viewpoints and Composition. New York: Theatre Communications Group, 2005.

BONDÍA, Jorge Larrosa. Notas sobre a experiência e o saber de experiência. In Revista Brasileira de Educação, n.19, 2002, p.20-28.

BONFITTO, Matteo. O ator-compositor. São Paulo: Perspectiva, 2002. BORIE, Monique. Enseignement et Création, un même chemin - Grotowski et Barba. Révue L'Art du Théâtre. Le Metteur en Scène-Pédagogue, n.8. Paris: Actes Sud,1987, p. 127 a 133.

BRAZ, Luzia Carion. Iniciação ao Treinamento do Ator através da técnica desenvolvida por Klauss Vianna. 2004. Dissertação (Mestrado em Artes Cênicas) - Escola de Comunicação e Artes, Universidade de São Paulo, São Paulo, 2004.

BRECHT, Bertolt. Estudos sobre Teatro. Para uma arte dramática nãoaristotélica. 3 ed. Lisboa: Portugália, 1957.

BROOK, Peter. 0 ponto de mudança. 2 ed. Rio de Janeiro: Civilização Brasileira, 1995.

BURCH, Noel. Práxis do Cinema. São Paulo: Perspectiva, 1969.

CALVINO, Ítalo. As cidades Invisíveis. São Paulo: Cia das Letras, 2000.

CASETTI, Francesco. Teorias del Cine. Madri: Ediciones Cátedra, S. A., 1994. CHARNEY, Leo; SCHWARTZ, Vanessa R. (org.) O cinema e a invenção da vida moderna. São Paulo: Cosac \& Naify, 2004.

CHAUÍ, Marilena. Janela da alma, espelho do mundo. In: NOVAES, Adauto (org). O Olhar. São Paulo: Cia. das Letras, 1988, p. 31-63.

COELHO, Teixeira. O que é ação cultural? São Paulo: Brasiliense, 2001.

COHEN, Renato. Performance como linguagem. 2a . edição. São Paulo: Perspectiva, 2007. 1998.

Work in progress na cena contemporânea. São Paulo: Perspectiva,

COSTA, Iná Camargo. Teatro de Grupo contra o deserto do Mercado. Revista Camarim, São Paulo, ano10, n. 40, p. 26-37, 2 . Semestre, 2007.

DANAN, Joseph. Dialogue Narratif, Dialogue Didascalique. In: RYNGAERT, Jean-Pierre (org.) Nouveaux Territoires du Dialogue. Paris: Actes SudPapiers, 2005, p.41-45.

DEBORD, Guy. A Sociedade do Espetáculo. Rio de Janeiro: Contraponto, 1997.

DESGRANGES, Flávio. A Pedagogia do Espectador. São Paulo: Hucitec, 2003.

DUNDJEROVIC, Aleksandar. The cinema of Robert Lepage. London: Wallflower Press, 2003.

The Theatricality of Robert Lepage's Transformative mise-enscène. Montreal: McGill-Queen's University Press, 2006.

EISEINSTEIN, Sergei. A forma do filme. Rio de Janeiro: Jorge Zahar Editor, 1990.

FÉRAL, Josette. La théâtralité: Recherche sur la spécificité du language théâtral. Poétique 75. Paris: Seuil, p. 347-361, 1988. 
. Un corps dans l'espace : perceptions et projection. Théâtre : espace sonore, espace visuel. Lyon : Presses Universitaires, 2003.

FERNANDES, Sílvia T. Grupos de teatrais, anos 70. Campinas: Editora da Unicamp, 2000.

. O Lugar da Vertigem. In: Trilogia Bíblica (Teatro da Vertigem). São Paulo: Publifolha, 2002 (p. 35-40)

Subversão no palco. Revista Humanidades. Brasília: Editora UnB, n.52, p.7-18, novembro de 2006. Edição Especial.

FORJAZ, Cibele. No palco, a luz. Revista Humanidades. Brasília: Editora UnB, n.52, p.67-76, novembro de 2006. Edição Especial.

GALIZIA, Luiz Roberto. Os processos criativos de Robert Wilson. São Paulo: Perspectiva, 2005.

GENETTE, Gérard. Frontière du récit. In BARTHES et al, L'analyse struturale du récit. Paris: Éditions du Seuil, 1981, p. 158-169.

GREINER, Christine. O Corpo - Pistas para Estudos Indisciplinares. São Paulo: AnnaBlume, 2005.

GUÉNOUN, Denis. O Teatro é necessário? São Paulo: Perspectiva, 2004.

HÉBERT, Chantal e PERELLI-CONTOS, Irene. L'écran de la pensée ou Les écrans dans le Théâtre de Robert Lepage. In : PICON-VALLIN, Béatrice (org.). Les écrans sur la scène. Paris, L'Age D'Homme, 1998, p.171-205.

HOUAISS, Antônio; VILLAR, Mauro de Salles. Dicionário Houaiss da Língua Portuguesa. Rio de Janeiro: Objetiva, 2001.

KA, Tâmara. Memória do efêmero. O DVD - registro de teatro. São Paulo: Annablume, 2008.

KATZ, Helena. Um, dois, três. A dança é o pensamento do corpo. Belo Horizonte: Helena Katz, 2005.

KNOPF, Robert. (Edited by) Theatre and film: a comparative anthology. New Haven and London: Yale University Press, 2005.

KOUDELA, Ingrid Dormien. Brecht na Pós-Modernidade. São Paulo: Perspectiva, 2001.

. Brecht: Um Jogo de Aprendizagem. São Paulo: Perspectiva, 1991.

. (org.) Heiner Müller - O espanto no teatro. São Paulo: Perspectiva, 2003.

. Jogos Teatrais. São Paulo: Perspectiva, 1998.

. Texto e Jogo. São Paulo: Perspectiva, 1999.

. (org.) Um Vôo Brechtiano. São Paulo: Perspectiva/FAPESP, 1992.

KRACAUER, Siegfried. Theory of film. London: Oxford University Press, 1960.

LE CORBUSIER. Por uma arquitetura. São Paulo: Perspectiva, 1994.

LEHMANN, Hans-Thies. Teatro pós-dramático. Tradução de Pedro Süssekind.

São Paulo: Cosac \& Naify, 2007.

. Le Théâtre postdramatique. Tradução de Philippe-Henri Ledru. Paris:

L'Arche, 2002.

Teatro Pós-Dramático e Teatro Político. Sala Preta. Revista de Artes Cênicas (ECA/USP), São Paulo, n.3, p. 9-19, 2003. 
Un théâtre du conflit. Alternatives Théâtrales. Bruxelas: Centre International de Formantion en Arts du Spectacle, n.76-77, p. 40-44, 2003. MACHADO, Rubens. Estudo sobre a organização do espaço em Terra em Transe. 1997. Tese (Doutorado em Cinema) - Escola de Comunicação e Artes, Universidade de São Paulo, São Paulo, 1997.

MALRAUX, André. Esboço de uma psicologia do cinema. Festival do Cinema Francês: catálogo. São Paulo, 1959, p. 90 - 92. Catálogo da Cinemateca Brasileira.

MARTINS, Marcos Aurélio Bulhões. Encenação em jogo. São Paulo: Hucitec, 2004.

MATERNO, Ângela. O Olho e a Névoa. Considerações sobre a teoria do teatro. Sala Preta. Revista de Artes Cênicas (ECA/USP), São Paulo, n.3, p. 31-41, 2003.

MAURIN, Frédéric. Au péril de La beauté : la chair du visuel et le cristal de la forme chez Robert Wilson. In : PICON-VALLIN, Béatrice (org.). La scène et les images. Paris, CNRS Éditions, 2004, p. 49-69.

MÉGEVAND, Martin. Choralité. In: RYNGAERT, Jean-Pierre (org.) Nouveaux Territoires du Dialogue. Paris: Actes Sud-Papiers, 2005, p.36-40.

MENDES, Ranulfo Alfredo Manevy de Pereira. Jean-Luc Godard e o cinema clássico americano - de Acossado a Made in USA. Tese (Doutorado em Cinema) - Escola de Comunicação e Artes, Universidade de São Paulo, São Paulo, 2004.

MERVANT-ROUX, Marie-Madeleine. Le ré-imaginement du monde. L'Art du Théâtre du Radeau. In : PICON-VALLIN, Béatrice (org.). La scène et les images. Paris, CNRS Éditions, 2004, p. 362-387.

METZ, Christian. A Significação no Cinema. 2 ed. São Paulo: Perspectiva, 2004.

MILLER, Jussara Corrêa. A escuta do corpo: abordagem da Técnica Klauss Vianna. São Paulo: Summus Editorial, 2007.

NAVES, Rodrigo. O Olhar difuso - Notas sobre a visualidade brasileira. Revista Gávea, PUC, Rio de Janeiro, n. 3, páginas?, junho de 1986.

NÉSPOLI, Beth. Conversa com o filósofo Paulo Arantes. Revista Camarim, São Paulo, ano 11, n. 41, p. 31-37, $1^{\circ}$.semestre, 2008.

PASOLINI, Piero Paolo. A poesia do novo cinema. Revista Civilização Brasileira, São Paulo, p. 267- 287, maio de 1966.

PAVIS, Patrice. A análise dos espetáculos. São Paulo: Perspectiva, 2005. . Dicionário de Teatro. São Paulo: Perspectiva, 1999.

. La théâtralité en Avignon. Vers une théorie de la pratique théatrale, Paris: Presses Universitaires du Septentrión, p. 317-337, 2000.

PICON-VALLIN, Béatrice. A arte do Teatro - entre tradição e vanguarda: Meyerhold e a cena contemporânea. Rio de Janeiro: Teatro do Pequeno Gesto: Letra e Imagem, 2006.

. La mise en scène : vision et images. In : PICON-VALLIN, Béatrice (org.). La scène et les images. Paris, CNRS Éditions, 2004, p. 11-31.

. Os mundos íntimos do Soleil. Sala Preta. Revista de Artes Cênicas (ECA/USP), São Paulo, n.7, p. 111-116, 2007. 
Stanislavski et Meyerhold, Metteurs en Scène-Pédagogues. Révue

L'Art du Théâtre : Le Metteur en Scène-Pédagogue, Paris, Actes Sud, n.8, p.105 a 110, 1987.

PUPO, Maria Lúcia de Souza Barros. Entre o Mediterrâneo e o Atlântico: uma aventura teatral. São Paulo: Perspectiva, Capes, FAPESP, 2005.

. Para desembaraçar os fios. Revista Educação e Realidade, Porto Alegre: UFRS, setembro 2006. Dossiê Ensino de Arte.

. Sinais de teatro-escola. Revista Humanidades. Brasília: Editora UnB, n.52, p.109-115, novembro de 2006. Edição especial

PUPPO, Eugênio; Xavier, Ismail (org.). Nelson Rodrigues e o Cinema: Traduções, Traições: catálogo de mostra de cinema. Rio de Janeiro: Heco Produções, 2004.

RAMOS, Luiz Fernando. A pedra de toque. Revista Humanidades, Brasília: Editora UnB, n.52, p.27-34, novembro de 2006. Edição especial.

ROCHA, Glauber. Estética da Fome. In ROCHA, Glauber. Revolução do Cinema Novo. Rio de Janeiro: Alhambra, Embrafilme, 1981.

ROUBINE, Jean-Jacques. A Linguagem da Encenação Teatral. Rio de Janeiro: Jorge Zahar, 1998.

RYNGAERT, Jean-Pierre. Dialogue et Conversation. In: RYNGAERT, JeanPierre (org.) Nouveaux Territoires du Dialogue. Paris: Actes SudPapiers, 2005, p.17-21. . Introdução à Análise do Teatro. São Paulo: Martins Fontes, 1996. . O Jogo Dramático no Meio Escolar. Coimbra: Centelha, 1981. . Jouer, Représenter (Pratiques dramatiques et Formation). Paris: Cedic, 1985. . Ler o Teatro Contemporâneo. São Paulo: Martins Fontes, 1998.

SARRAZAC, Jean-Pierre. Choralité - Note sur le théâtre postdramatique. Alternatives Théâtrales, Bruxelas : Centre International de Formation en Arts du Spectacle, n.76-77, p. 28-29, 2003.

. Le partage de voix. In: RYNGAERT, Jean-Pierre (org.) Nouveaux

Territoires du Dialogue. Paris : Actes Sud-Papiers, 2005, p.11-16.

L'invention de la théâtralité.Critique du Théâtre. De l'utopie au désenchantement. Paris: Circé, p. 53-71, 2000.

SCHECHNER, Richard. O que é performance? In: Revista Percevejo, Rio de Janeiro, n. 12, Ano 11, p.25-50, 2003.

SOARES, Carmela Corrêa. Pedagogia do Jogo Teatral: uma Poética do Efêmero. O Ensino do Teatro na Escola Pública. Dissertação (Mestrado em Artes Cênicas) - UNIRIO, Rio de Janeiro, 2003.

SOUZA, Gilda Mello e. Exercício de leitura. São Paulo: Livraria Duas Cidades, 1980.

SPOLIN, Viola. Improvisação para o teatro. 4 ed. São Paulo: Perspectiva, 1998. 2001.

Jogos Teatrais: o Fichário de Viola Spolin. São Paulo: Perspectiva,

SZONDI, Peter. Teoria do Drama Moderno. São Paulo: Cosac \& Naify, 2001.

TARKOVSKI, Andrea. Esculpir o Tempo. São Paulo: Martins Fontes, 1998. 
UBERSFELD, Anne. Para ler o teatro. São Paulo: Perspectiva, 2005.

VIANNA, Klauss. A Dança. 2 ed. São Paulo: Siciliano, 2005.

XAVIER, Ismail. Cinema Brasileiro Moderno. São Paulo: Paz e Terra, 2001. . O Discurso Cinematográfico: a opacidade e a transparência. Rio de Janeiro: Paz e Terra, 2005. . (org.) A experiência do cinema. São Paulo: Graal, 2003. . O Olhar e a Cena. São Paulo: Cosac \& Naify, 2003.

. O olhar e a voz - A narração multifocal do cinema e a cifra da História em São Bernardo. Revista Literatura e Sociedade, São Paulo, n. 2, p.126-138, 1997. . Impulsos Críticos do Cinema Moderno. Revista Vintém, São Paulo, n.6, p. 5-15, 2007. Revista da Cia. do Latão.

\section{Documentos eletrônicos:}

CARREIRA, André. Teatro de grupo anos 1990. Disponível em: <http:// www.itaucultural.org.br/proximoato >. Acesso em: 26/06/2008.

HEEG, Günther. Práticas coletivas em tempos pós-dramáticos. Disponível em: <http://www.itaucultural.org.br/próximoato >. Acesso em: 26/06/2008.

PÉLBART, Peter Pál. Elementos para uma cartografia da grupalidade. Disponível em: <http://www.itaucultural.org.br/próximoato>. Acesso em: 26/06/2008. 